\title{
I3) ân'?
}

Вопгоградского государственного технического

\section{университета}
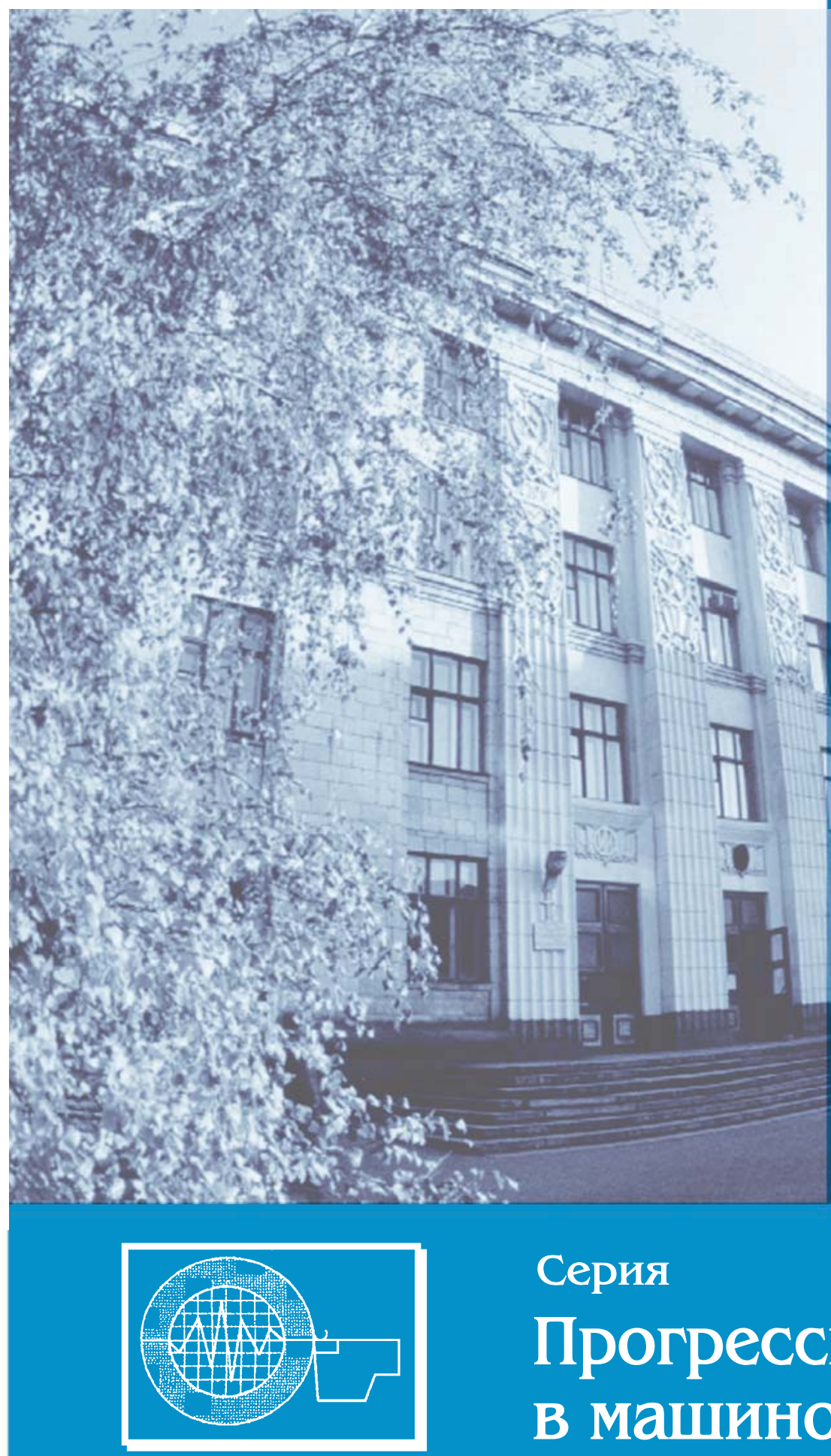

\section{Серия}

Прогрессивные технопогии

в машиностроении

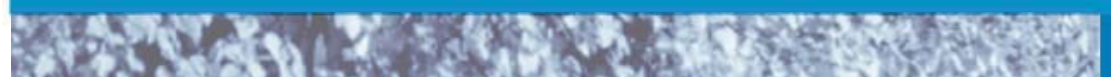

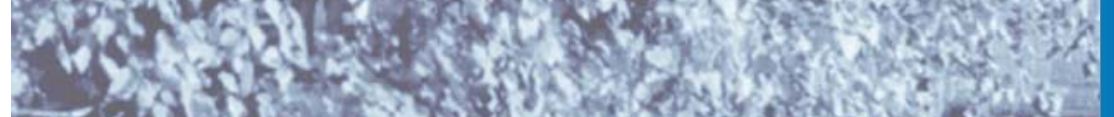
Fon

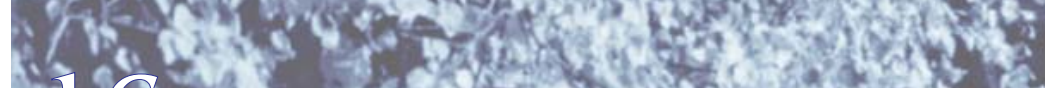

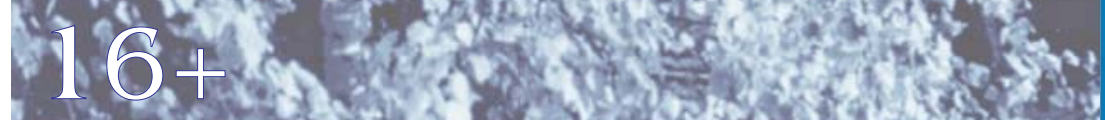

№ 8 (255)

2021 
Главный редактор научного журнала

«Известия Волгоградского государственного технического университета»

академик РАН, профессор, доктор химических наук,

президент Волгоградского государственного технического университета (ВолгГТУ)

И. А. НОВАКОВ

Редакционная коллегия:

Байбурин В. Б., д-р физ.-мат. наук, проф., академик РАЕН, засл. деятель науки РФ,

Саратовский государственный технический университет (г. Саратов, Россия)

Безъязычный В. Ф., д-р техн. наук, проф.,

Рыбинский государственный авиационный технический университет им. П. А. Соловьева (г. Рыбинск, Россия)

Бодров В. Н., д-р, проф., Университет прикладных наук (г. Берлин, Германия)

Бребельс A., PhD, доцент факультета инженерных наук университета г. Левена (г. Левен, Бельгия)

Буренин А. А., чЛ.-корр. РАН, Институт машиноведения и металлургии ДВО РАН

(г. Комсомольск-на-Амуре, Россия)

Голованчиков А. Б., д-р. техн. наук, проф. ВолгГТУ

Гринберг Б. А., д-р физ.-мат. наук, Институт физики металлов УрО РАН (г. Екатеринбург, Россия)

Гуревич Л. М., д-р техн. наук, доц. ВолгГТУ

Добрушин Л. Д., Д-р техн. наук, Институт электросварки им. Е. О. Патона НАН Украины (г. Киев, Украина)

Злотин С. Г., Д-р хим. наук, проф., Институт органической химии им. Н. Д. Зелинского РАН (г. Москва, Россия)

Иванов А. М., д-р техн. наук, проф.,

Московский автомобильно-дорожный государственный технический университет (МАДИ, г. Москва, Россия)

Иващенко Н. А., д-р техн. наук, проф., засл. деятель науки РФ, МГТУ им. Н. Э. Баумана (г. Москва, Россия)

Королев А. В., д-р техн. наук, проф., Саратовский государственный технический университет (г. Саратов, Россия)

Кузьмин С. В., д-р техн. наук, проф. ВолгГТУ

Кураев A. A., д-р физ.-мат. наук, проф., Белорусский государственный университет информатики и радиоэлектроники

(БГУИР, г. Минск, Республика Беларусь)

Лысак В. И., академик РАН, засл. деятель науки РФ, д-р техн. наук, проф. ВолгГТУ

Марков B. A., Д-р техн. наук, проф., Московский государственный технический университет

(МГТУ) им. Н. Э. Баумана (г. Москва, Россия)

Мертен Клеменс, д-р техн. наук, проф. Universität Stuttgart Institut für Chemische Verfahrenstechnik

(г. Штутгарт, Германия)

Наврочкий А. В., д-р хим. наук, проф. ВолгГТУ

Нижегородиев Р. М., д-р экон. наук, Институт проблем управления им. В. А. Трапезникова РАН (г. Москва, Россия)

Пай В. В., д-р физ.-мат. наук, Институт гидродинамики им. М. А. Лаврентьева СО РАН (г. Новосибирск, Россия)

Пустовойт В. Н., д-р техн. наук, проф., засл. деятель науки РФ, Донской государственный технический университет

(г. Ростов-на-Дону, Россия)

Русинов В. Л., чЛ.-корр. РАН, Химико-технологический институт Уральского федерального университета

(ХТИ УрФУ, г. Екатеринбург, Россия)

Рыбин В. В., чл.-корр. РАН, д-р физ.-мат. наук, проф.,

Санкт-Петербургский политехнический университет (г. Санкт-Петербург, Россия)

Трюэль Жан-Луи, д-р экон. наук, проф., Университет «Париж-12», Сорбонна, Франция,

вице-президент Международного клуба экономистов «Круг Кондратьева»

Тхай Куанг Винь, д-р философии, Институт информационных технологий (г. Ханой, Вьетнам)

Федянов Е. А., д-р техн. наук, проф. ВолгГТУ

Фролов В. А., д-р техн. наук, проф., МАТИ - Российский государственный технологический университет

им. К. Э. Циолковского (г. Москва, Россия)

Шарипов В. М., д-р техн. наук, проф.,

Московский государственный технический университет (МАМИ, г. Москва, Россия)

Шаховская Л. С., Д-р экон. наук, проф. ВолгГТУ

Щербаков М. В., д-р техн. наук, проф. ВолгГТУ 
Серия

«ПРОГРЕССИВНЫЕ

ТЕХНОЛОГИИ

В МАШИНОСТРОЕНИИ»

\section{ВОЯГОГРАДСКОГОГОСУДАРСТВЕННОГО ТЕХНИЧЕСКОГО УНИВЕРСИТЕТА}

Журнал входит в перечень утвержденных ВАК РФ изданий для публикации трудов соискателей ученых степеней

\section{РЕДАКЦИОННЫЙ} СOBET:

Председатель

Чигиринский Ю. Л., д.Т.Н., доц. Сердобинщев Ю. П., д.т.н., проф. (зам. председателя)

Безъязычный В. Ф., д.т.н. проф.

(РГАТУ им. П. А. Соловьева,

г. Рыбинск)

Схиртладзе А. Г., д.т.н. проф.

(МГТУ «СТАНКИН», г. Москва)

Мухин А. В., д.т.н. проф.

(МГТУ им. Н. Э. Баумана, г. Москва)

Бржсозовский Б. М., д.т.н. проф.

(СГТУ, г. Саратов)

Королев А. В., д.т.н. проф.

(СГТУ, г. Саратов)

Шумячер В. М., д.т.н., проф.

(ВПИ, филиал ВолгГТУ,

г. Волжский)

Сидякин Ю. И., д.т.н., проф.

Благовещенская М. М., д.т.н., проф. проректор (МГУПП, г. Москва)

Пашков Е. В., д.т.н., проф. первый проректор (СевНТУ, г. Севастополь)

Попов В. И., д.т.н., проф.

(МГУПБ, г. Москва)

Сердобинцев С. П., д.т.н., проф.

(КТУ, г. Калининград)

Плотников А. Л., д.т.н., проф.

Тихонова Ж. С.

(ответственный секретарь)

Международный индекс журнала ISSN 1990-5297.

Журнал распространяется

по подписке.

Индекс журнала по каталогу

Агентства «Роспечать»

для Российской Федерации -

80811(ОК+ЭК)

Тел. издательства ВолгГТУ:

8-(8442) 24-84-08

$8-(8442)$ 24-84-05

zavrio@vstu.ru
Научный журнал

Издается с января 2004 г.

Выходит двенадцать раз в год

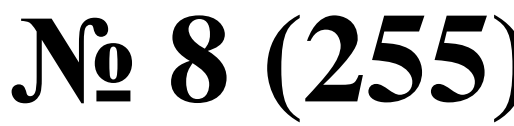

Aвгуст
2021

УЧРЕДИТЕЛЬ:

ФГБОУ высшего образования «Волгоградский государственный технический университет»

Адрес редакции:

Волгоград, пр. В. И. Ленина, 28

Телефон: гл. редактор - (8442) 24-80-00

E-mail: president@vstu.ru

Журнал зарегистрирован в Федеральной службе по надзору в сфере связи, информационных технологий и массовых коммуникаций (Роскомнадзор)

Свидетельство о регистрации ПИ № ФС77-61113 от 19 марта 2015 г.

Печатается по решению редакционно-издательского совета Волгоградского государственного технического университета Авторское право на журнал в целом принадлежит Учредителю, на отдельные статьи - сохраняется за автором

Перепечатка из журнала «Известия Волгоградского государственного технического университета» категорически запрещена без оформления договора в соответствии с действуюшим законодательством РФ

При перепечатке материалов ссылка на журнал «Известия Волгоградского государственного технического университета» обязательна

(c) Водгоградский государственный технический университет,

«Известия Волгоградского государственного технического университета», 2021 
Head Editor of the scientific journal "Izvestiya VSTU":

Novakov I. A. - Academician of RAS, Prof., Doctor of Chemistry, President of VSTU

\section{Editorial board:}

Baiburin V. B., D. Sc. (Physical and Mathematical Sciences), Prof., Academician of RANS, Honored Scientist of the Russian Federation, State Technical University of Saratov (Saratov, Russia)

Bezyazychny V. F., D. Sc. (Engineering), Prof., Rybinsk State Aviation Technical University named after P.A. Solovyov (Rybinsk, Russia)

Bodrov V. N., D. Sc., Prof., University of Applied Sciences (Berlin, Germany)

Brebels A., PhD, Associate Prof., Faculty of Engineering Science of University of Leuven (Leuven, Belgium)

Burenin A. A., Corresponding Member of RAS, Institute of Machinery and Metallurgy of the FEB RAS (Komsomolsk-on-Amur, Russia)

Golovanchikov A. B., D. Sc. (Engineering), Prof. of VSTU

Grinberg B. A., D. Sc. (Physical and Mathematical Sciences), Institute of Metal Physics, Ural Division of RAS (Ekaterinburg, Russia)

Gurevich L. M., D. Sc. (Engineering), Associate Prof. of VSTU

Dobrushin L. D., D. Sc. (Engineering), E.O. Paton Electric Welding Institute of the National Academy of Sciences of Ukraine (Kiev, Ukraine)

Zlotin S. G., D. Sc. (Chemistry), Prof., N.D. Zelinsky Institute of Organic Chemistry Russian Academy of Sciences (Moscow, Russia)

Ivanov A. M., D. Sc. (Engineering), Prof., Moscow Automobile and Road Construction University (MADI) (Moscow, Russia)

Ivashchenko N. A., D. Sc. (Engineering), Prof., Honored Scientist of the Russian Federation, Bauman Moscow State Technical University (Moscow, Russia)

Korolev A. V., D. Sc., Prof., State Technical University of Saratov (Saratov, Russia)

Kuzmin S.V., D. Sc. (Engineering), Prof. of VSTU

Kurayev A. A., D. Sc. (Physical and Mathematical Sciences), Prof., Belarusian State University of Informatics and Radioelectronics (BSUIR) (Minsk, Republic of Belarus)

Lysak V. I., Academician of RAS, Honored Scientist of the Russian Federation, D. Sc. (Engineering), Prof. of VSTU Markov V. A., D. Sc. (Engineering), Prof., Bauman Moscow State Technical University (Moscow, Russia)

Merten K., D. Sc. (Engineering), Prof., Institute of Chemical Process Engineering (Stuttgart, Germany)

Navrotskiy A. V., D. Sc. (Chemistry), Prof. of VSTU

Nizhegorodtsev R. M., D. Sc. (Economy), Chief research worker, Institute of Control Sciences V. A. Trapeznikov Academy of Sciences (Moscow, Russia)

Pai V. V., D. Sc. (Physical and Mathematical Sciences), Lavrentyev Institute of Hydrodynamics of SB RAS (Novosibirsk, Russia)

Pustovoit V. N., D. Sc. (Engineering), Prof., Honored Scientist of the Russian Federation, Don State Technical University (Rostov-on-Don, Russia)

Rusinov V. L., Corresponding Member of RAS, Institute of Chemical Technology of Ural Federal University (Ekaterinburg, Russia)

Rybin V. V., Corresponding Member of RAS, D. Sc. (Physical and Mathematical Sciences), Prof., St. Petersburg Polytechnic University (St.Petersburg, Russia)

Thai Quang Vinh, D. Sc. (Philosophy), Institute of Information Technology (Hanoi, Vietnam)

Truel J.-L., D. Sc. (Economy), Prof., University Paris Est Créteil, Sorbonne, France, Vice-president of International economists club "Kondratiev Circle"

Fedyanov E. A., D. Sc. (Engineering), Prof. of VSTU

Frolov V. A., D. Sc. (Engineering), Prof., "MATI Russian State Technological University named after

K.E. Tsiolkovsky" (Moscow, Russia)

Sharipov V. M., D. Sc. (Engineering), Prof., Moscow State Technical University “MAMI” (Moscow, Russia)

Shakhovskaya L. S., D. Sc. (Economy), Prof. of VSTU

Shcherbakov M. V., D. Sc. (Engineering), Prof. VSTU 
The Journal is included to the list of peer-reviewed scientific journals and publications of the Higher Attestation Commission (HAC) of the RF for publishing of results of candidates for scientific degrees

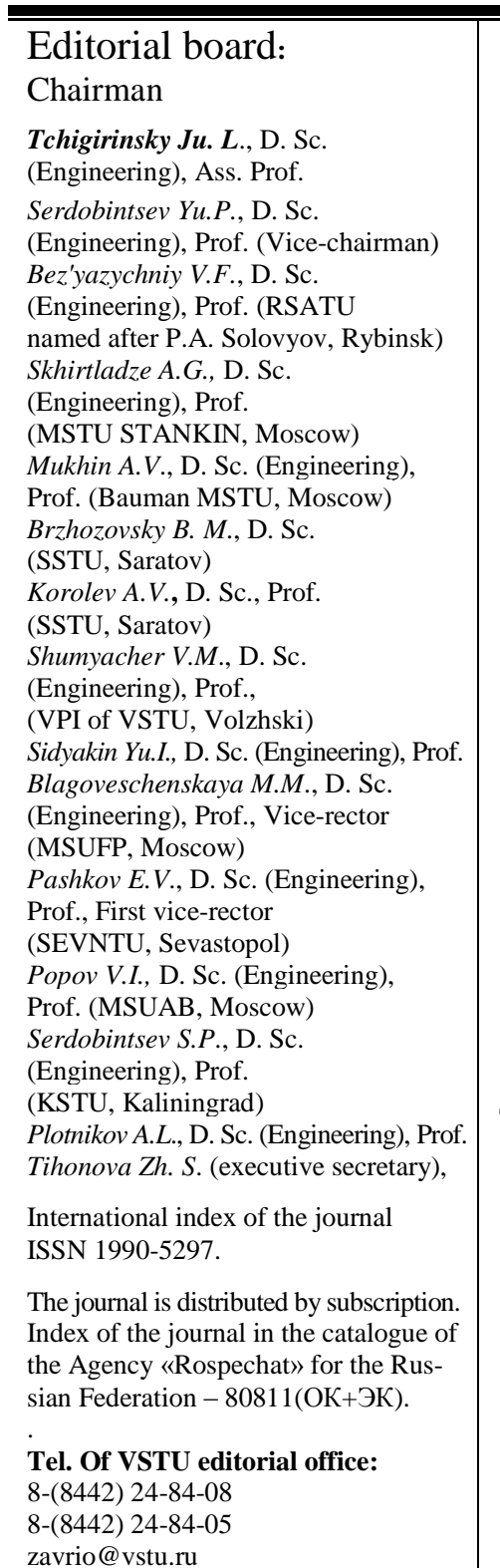

Reprint from the journal «Izvestia VSTU» is strongly forbidden without conclusion of an agreement in accordance with the legislation of the $R F$ When reprinting the materials, the citation to the journal «Izvestia VSTU» is obligatory

(C) Volgograd State Technical University, «Izvestia VSTU», 2021 
Абалхан Д. Ю. 49

Агапов С. И. 7

Аржуханов Р. И. 9, 30

Багайсков Ю. С. 68

Банников А. И. 9

Барабанов В. Г. 61, 78

Батуев Ц. А. 14

Бордюгов Д. В. 52

Брискин Е. С. 52

Ваганов А. В. 55

Васильев П. С. 78

Вирт А. Э. 16

Волков И. В. 55

Галсанова Э. Ц. 57

Горбунов М. Г. 61

Грешилов А. Д. 57

Гулевский В. В. 87

Гущин И. А. 81

Давыдова И. И. 75

Драпак К. А. 65, 75

Драчев О. И. 21

Дроботов А. В. 81

Жданов А. А. 30, 37

Забродин А. В. 68

Заярный Д. В. 7

Иващенко А. П. 16

Калинин Я. В. 49, 57

Каргина Ж. А. 24

Карлов В. И. 26

Козловцева Н. В. 65

Кравцов А. Н. 21

Крайнев Д. В. 24

Крылов Е. Г. 65, 75

Крыхтин Ю. И. 26

Кухтик М. П. 72
Лапиков М. А. 55

Лисов К. Д. 14

Макаров А. М. 65, 75

Макарова О. А. 9, 30

Малолетов А. В. 52

Носенко В. А. 34, 42

Орлов С. В. 42

Панюлайтис А. С. 78

Пеньшин И. С. 87

Плотников А. Л. 37,81

Прохватилов А. С. 7

Пузырькова В. Е. 34

Репников А. И. 72

Санинский В. А. 46

Саразов А. В. 42

Семенов Е. Д. 14

Сердобинцев Ю. П. 72

Сердюков Н. Д. 34

Сиукова Е. О. 9, 30

Слепцов Д. С. 34

Сурганов Н. А. 49

Тихонова Ж. С. 37

Толстяков А. Ф. 7

Торубаров И. С. 81

Тышкевич В. Н. 42

Ушаков Н. А. 46

Федянов Е. А. 46

Фоменко С. С. 52

Хаустов М. А. 72

Чигвинцев Р. А. 49

Шаронов Н. Г. 87

Шатов М. С. 14

Шемелюнас С. С. 55

Яковлев А. А. 57 


\section{Ч а с т ь 1. ТЕХНОЛОГИЯ МАШИНОСТРОЕНИЯ}

Агапов С. И., Прохватилов А. С., Толстяков А. Ф., Заярный Д. В. Особенности процессов стружкообразования при традиционном и ультразвуковом зубонарезании.

Банников А. И., Макарова О. А., Аржуханов Р. И, Сиукова Е. О. Распределение тепла в зубе пилы с модифицированной геометрией при пакетной резке холодного металлопроката..

Батуев Ц. А., Шатов М. С., Лисов К. Д., Семенов Е. Д.

Разработка установки для горячего формования авиационного остекления из органического стекла с применением аддитивных технологий

Вирт А. Э., Иващенко А. П.

Изменение конструкции раскатывающего инструмента, повышающее его надежность

Драчев О. И., Кравиов А. Н.

Двухрезцовое точение тел вращения.

Каргина Ж. А., Крайнев Д. В.

Организация СМК как направление

повышения конкурентоспособности предприятия

Карлов В. И., Крыхтин Ю. И.

К оценке и прогнозированию триботехнических показателей пар трения из спеченного порошкового фрикционного материала

с разными стальными контртелами дискового фрикционного устройства.....

Макарова О. А., Жданов А. А., Аржуханов Р. И., Сиукова Е. О.

Определение оптимального заднего угла пилы пакетной резки

с использованием моделирования тепловых полей.

Носенко В. А., Пузырькова В. Е., Сердюков Н. Д., Слепиов Д. С.

Влияние среды на показатели процесса шлифования сталей

и титановых сплавов инструментом из корунда и карбида кремния

Плотников А. Л., Тихонова Ж. С., Жданов А. А.

Методы оценки теплофизических свойств контактной пары «инструмент - стальная заготовка» и возможность их использования при расчете параметров процесса токарной обработки

Тыликевич В. Н., Носенко В. А., Саразов А. В., Орлов С. В.

Упругие деформации призматических заготовок малой жесткости при плоском шлифовании

Федянов Е. А., Санинский В. А., Ушаков Н. А.

Методика расчета количества дросселирующих элементов многозубого дорна.

Часть 2. АВТОМАТИЗАЦИЯ ПРОИЗВОДСТВЕННЫХ ПРОЦЕССОВ

Абалхан Д. Ю., Калинин Я. В., Сурганов Н. А., Чигвинцев Р. А.

Разработка первого яруса прицепного коноплеуборочного комбайна.........

Бордюгов Д. В., Фоменко С. С., Малолетов А. В., Брискин Е. С.

Лабораторная модель мобильного робота с секционным движителем.............

Ваганов А. В., Лапиков М. А., Волков И. В., Шемелюнас С. С.

Устройство для автоматизированного манипулирования биг-бэгами...............

Галсанова Э. Ц., Грешилов А. Д., Калинин Я. В., Яковлев А. А.

Исследование методов нагрева заготовок

при горячей листовой штамповке. 
Горбунов М. Г., Барабанов В. Г.

Модернизация устройства управления рольгангами для транспортировки трубной заготовки ....

Драпак К. А., Крылов Е. Г., Макаров А. М., Козловиева Н. В.

Перспективы развития проектов по производству СПГ в России.

Забродин А. В., Багайсков Ю. С.

Разработка конструкции рыбозащитного устройства.

Кухтик М. П., Репников А. И., Сердобинцев Ю. П., Хаустов М. А.

Разработка программы управления и НМІ-интерфейса

для системы предотвращения аварийных ситуаций

в опоре скольжения газоперекачивающего агрегата

Макаров А. М., Давыдова И. И., Драпак К. А., Крылов Е. Г.

Автоматизированное лечебно-оздоровительное устройство.

Панюлайтис А. С., Барабанов В. Г., Васильев П. С.

Разработка автоматизированной системы испарительного охлаждения методических печей с использованием гидравлических форсунок и капельного кипения жидкости.....

Торубаров И. С., Дроботов А. В., Плотников А. Л., Гущин И. А.

Развитие технологии 3D печати с армированием непрерывным волокном....

Шаронов Н. Г., Пеньшин И. С., Гулевский В. В.

Экспериментальная установка исследования

технологии позиционирования якорно-тросовых движителей

К сведению авторов. 


\section{ТЕХНОЛОГИЯ МАШИНОСТРОЕНИЯ}

УДК 621.9.048.6

DOI: $10.35211 / 1990-5297-2021-8-255-7-9$

\section{С. И. Агапов, А. С. Прохватилов, А. Ф. Толстяков, Д. В. Заярный \\ ОСОБЕННОСТИ ПРОЦЕССОВ СТРУЖКООБРАЗОВАНИЯ ПРИ ТРАДИЦИОННОМ И УЛЬТРАЗВУКОВОМ ЗУБОНАРЕЗАНИИ}

\section{Волгоградский государственный технический университет}

E-mail: stanki@vstu.ru

Рассматриваются вопросы особенности процесса механической обработки при нарезании мелкомодульных зубчатых колес с наложением ультразвуковых колебаний на заготовку.

Ключевые слова: нарезание мелкомодульных зубчатых колес, ультразвуковые колебания.

\section{S. I. Agapov, A. S. Prokhvatilov, A. F. Tolstyakov, D. V. Zayry \\ PECULIARITIES OF THE PROCESS OF ULTRASONIC VIBRATION MASHINING}

\section{Volgograd State Technical University}

The paper discusses the distinctive features of the machining process during low-module gear cutting with ultrasonic vibration of the blank.

Keywords: fine-pitch gear cutting, ultrasonic vibration.

Контактные явления, происходящие при нарезании мелкомодульных зубчатых колес с наложением ультразвуковых колебаний (УЗК), сопровождаются интенсивным трением на передней и задней поверхностях инструмента, которое оказывает существенное влияние на ряд важных характеристик процесса резания: на характер и интенсивность износа, качество обработанной поверхности, силы резания, точность обработки.

При традиционном зубонарезании отделение стружки сопровождается ее скольжением по передней поверхности в условиях либо граничного трения без существенных вторичных пластических деформаций контактного слоя, либо при полном схватывании контактных поверхностей с интенсивной пластической деформацией этого слоя [1]. При этом прерывистость процесса резания обусловлена в основном естественным чередованием режущих кромок инструмента. При введении в зону резания УЗК равномерность процесса резания нарушается даже в пределах толщины заготовки, при этом степень неравномерности зависит от начальной амплитуды и частоты УЗК, а также технологических режимов обработки.
Высокочастотные вибрации при лезвийной обработке изменяют физическую картину и механизм превращения отдельных элементов срезаемого слоя в стружку. Эти изменения касаются, главным образом, основных физических процессов стружкообразования: пластического деформирования и разрушения обрабатываемого материала, а также трения на контактирующих поверхностях, что, несомненно, должно отразиться на и механизме формирования отдельных элементов стружки.

Реакция трибологической системы при введении УЗК в зону резания осуществляется в основном через изменение молекулярной составляющей эффективного коэффициента трения и, таким образом, зависит от всех тех факторов, которые в той или иной степени влияющих на адгезионное взаимодействие сопряженных элементов контактной области. При осевых по отношению к заготовке УЗК с амплитудами 3...6 мкм молекулярная составляющая коэффициента трения в контактной зоне уменьшается соответственно в $1,2 \ldots 1,4$ раза, причем характер зависимости довольно устойчивый и сохраняется вплоть до амплитуды колебаний 10 мкм, при которой это уменьшение приближается уже к трем [2]. 
На рисунке представлены фотографии поверхностей стружек контактирующих и не контактирующих с передней поверхностью инструмента. Если при традиционном зубофрезеровании мелкомодульных зубчатых колес поверхность стружек, прилегающая к передней поверхности инструмента, после контакта имеет вследствие повышенного трения грубые задиры, на ней видны следы от срыва нароста, то
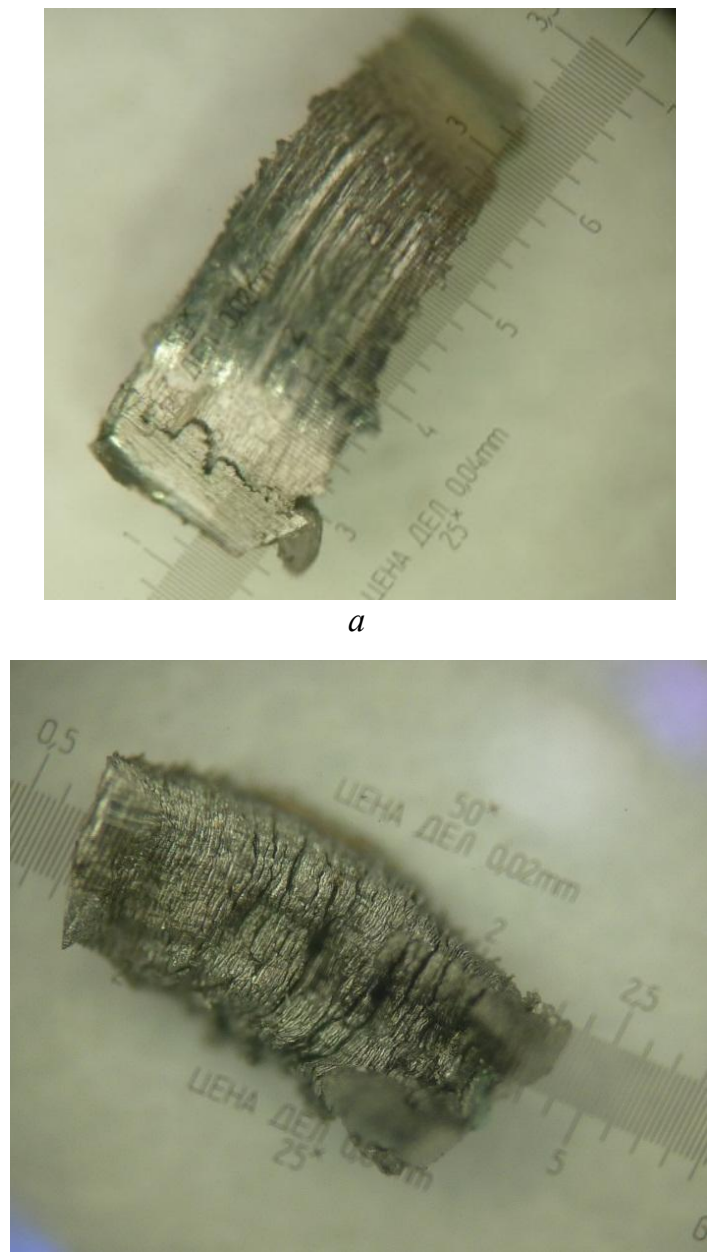

B при совмещенной с УЗК обработке эти поверхности относительно гладкие. Аналогичная картина наблюдается и на поверхностях стружек, не контактирующих с передней поверхностью инструмента, на которых хорошо просматриваются следы скалывания, а при УЗК - даже оплавления, несмотря на пониженное трение, поскольку срезаются относительно тонкие и насквозь прогреваемые слои металла.
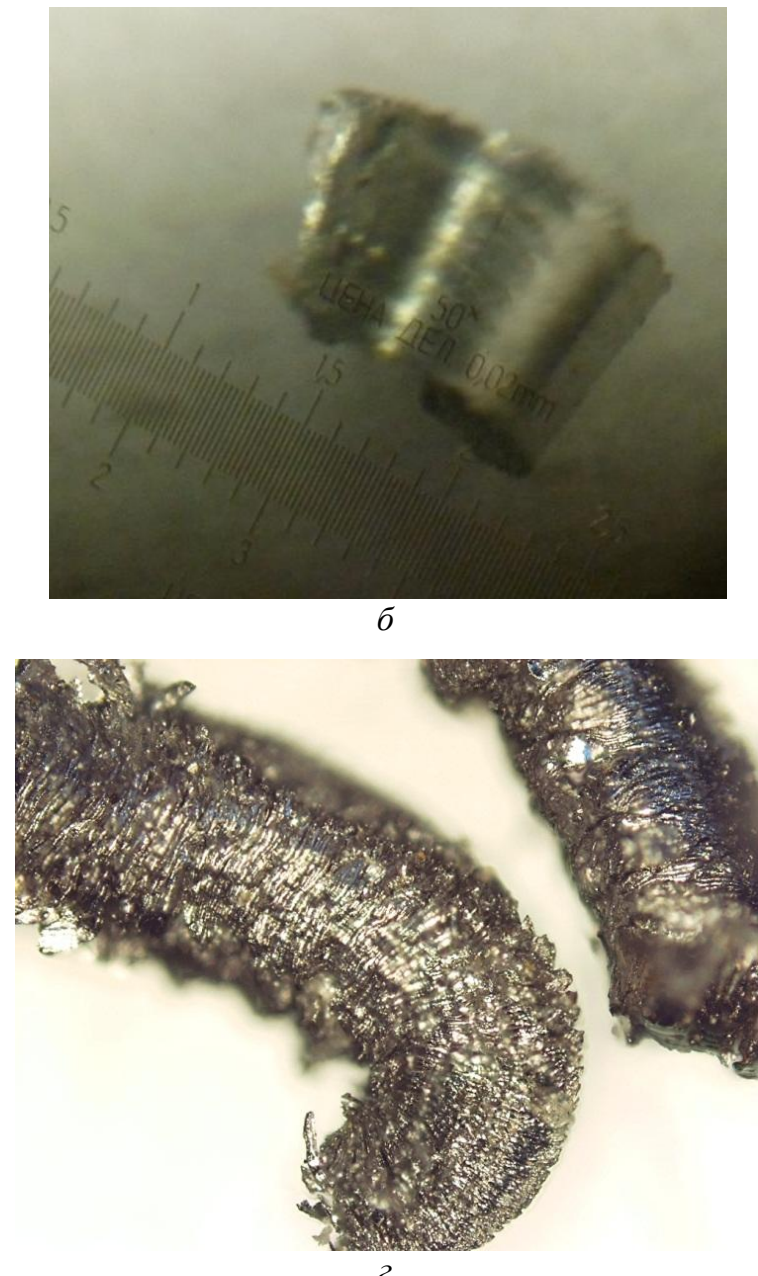

2

Фотографии поверхностей стружек, контактирующих $(a, \sigma)$ и не контактирующих $(b, 2)$ с передней поверхностью инструмента $(\times 20)$.

Заготовка: сталь 40X; фреза: Р6М5, $m=0,9$ мм; режим резания: $S=0,48$ мм/об, $V_{p}=0,5$ м/с: $a$, в - традиционная обработка; $\sigma, 2$ - обработка с УЗК в зоне резания

Определенный интерес исследование влияние скоростного режима традиционного и совмещенного с УЗК зубонарезания на микротвердость отдельных частей поверхности стружек и, в конечном счете, на микротвердость рабочих поверхностей зубчатого колеса.

Для приготовления микрошлифов использовалась заливка стружек эпоксидным компаундом с последующей их шлифовкой и поли- ровкой. Такой метод подготовки поверхностей для измерения микротвердости предназначен для очень малых (микроскопических) объемов материала отдельных фаз или структурных составляющих и ликвидации разницы в уровне твердости отдельных участков.

Результаты показывают, что стружка, полученная при зубофрезеровании мелкомодульных зубчатых колес, состоит их двух частей: основ- 
ной части и тонкого слоя, прилегающего к передней поверхности инструмента, который называется «заторможенным» слоем.

Заторможенный слой при малых скоростях обработки имеет сравнительно небольшую протяженность с периодическим повторением, возможен также срыв нароста, который находится между заторможенным слоем и основной стружкой.

При введении УЗК в зону резания процесс стружкообразования облегчается, поэтому зона вторичной деформации располагается по всей длине стружки без видимых следов разрыва [3]. Между срезаемым слоем и образовавшейся стружкой существует более или менее отчетливо выраженная переходная зона. При обработке, когда условия трения на передней поверхности особенно тяжелы, тормозящее действие, оказываемое режущим инструментом, становится настолько большим, что приводит к плотному присоединению части стружки к передней поверхности и образованию заторможенного слоя, что отчетливо видно на фотографиях микрошлифов. Из этого можно сделать вывод: на участке пластического контакта поверхность стружки настолько плотно прижата к передней поверхности инструмента, что часть стружки перемещается не по передней поверхности инструмента, а по заторможенному слою, вследствие чего в средней части стружек может образовываться прорыв металла, который неоднократно наблюдался и ранее [4,5] при тради- ционном фрезеровании. Заторможенный слой образуется при резании пластических и вязких материалов при малых передних углах профиля инструмента и скоростях резания, а также при отсутствии или недостаточном охлаждении.

\section{БИБЛИОГРАФИЧЕСКИЙ СПИСОК}

1. Марков, А. И. Ультразвуковая обработка материалов / А. И. Марков. - М. : Машиностроение, 1980. -237 с.

2. Подураев, B. Н. Обработка резанием с вибрациями / В. Н. Подураев. - М. : Машиностроение, 1970. - 350 с.

3. Агапов, С. И. Нарезание мелкомодульных зубчатых колес с использованием энергии ультразвуковых колебаний : монография / С. И. Агапов, Ю. И. Сидякин ; ВолгГТУ. - Волгоград, 2018. - 287 с.

4. Agapov, S. I. Operating Efficiency of Worm Gears Under Ultrasonic Vibration Imposition in the Cutting Region / S.I. Agapov, Yu.I.Sidyakin, A. F. Tolstyakov // Proceedings of the 5th International Conference on Industrial Engineering (ICIE 2019) (Sochi, Russian Federation, March 25-29, 2019). Vol. II, part 2 / ed. by A. A. Radionov [et al.] ; South Ural State University (National Research University), Moscow Polytechnic University, Platov South-Russian State Polytechnic University, Volgograd State Technical University. - Cham (Switzerland) : Springer Nature Switzerland AG, [2020]. - P. $1137-$ 1147. - URL : https://link.springer.com/book/10.1007/978-3030-22063-1. - (Book ser.: Lecture Notes in Mechanical Engineering - LNME).

5. Agapov, S. I. Calculation of Roughness Parameters during Ultrasonic Hobbing from the Viewpoint of the Theory of Elastic-Plastic Contact / S.I. Agapov, Yu.I.Sidyakin, O.F. Korpelyanskiy // Materials Science Forum. - 2019. - Vol. 973 : IX Int. Sci. and Techn. Conf. on Engineering - Innovation Technol. in Eng.: From Design to Production of Competitive Products (Volgograd, Sept. 2017) : Proc. / eds. A. Suslov, V. Lysak, Ju. Chigirinskiy [et al.] ; Volgograd St. Techn. Univ. - P. 170-173.

\section{А. И. Банников, О. А. Макарова, Р. И. Аржуханов, Е. О. Сиукова \\ РАСПРЕДЕЛЕНИЕ ТЕПЛА В ЗУБЕ ПИЛЫ С МОДИФИЦИРОВАННОЙ ГЕОМЕТРИЕЙ ПРИ ПАКЕТНОЙ РЕЗКЕ ХОЛОДНОГО МЕТАЛЛОПРОКАТА}

\section{Волгоградский государственный технический университет \\ E-mail: alc19@mail.ru}

В настоящей публикации рассматривается вопрос, связанный с исследованием распределения тепла в зубе пилы с модифицированной геометрией с учетом периодичности процесса резания холодного металлопроката дисковыми пилами.

Ключевые слова: дисковые пилы, пакет труб, пакетная резка, температурное поле.

\section{A. I. Bannikov, O. A. Makarova, R. I. Arzhanov, E. O. Siukova \\ HEAT DISTRIBUTION IN THE TOOTH OF A SAW WITH A MODIFIED GEOMETRY DURING BATCH CUTTING OF COLD ROLLED STEEL \\ Volgograd State Technical University}

This publication deals with the issue related to the study of the heat distribution in the tooth of a saw with a modified geometry, taking into account the frequency of the process of cutting cold rolled metal with circular saws.

Keywords: disk saw, pipe bundle (batch), batch saw cutting, temperature field.

(С Банников А. И., Макарова О. А., Аржуханов Р. И., Сиукова Е. О., 2021. 
В работе рассматривается распределение тепловых потоков в зубе пилы модифицированной геометрии при резании холодного металлопроката дисковыми пилами в ТПЦ - 2 АО ВТЗ.

Пакетная резка салазковой пилой характеризуется высокой производительностью и нашла широкое применение в производственных условиях металлургических предприятий. В тоже время значительный износ инструмента требует анализа тепловых процессов $[1,2]$.

Удаления материала из зоны обработки сопровождается выделением большого количества тепла вследствие трения задней поверхности инструмента об обрабатываемый материал. Значительное увеличение температуры приводит к интенсивному износу, выражающимся в деформации зубьев пилы. Нагрев зубьев стандартных дисковых пил был рассмотрен в работе [2].
Изменение геометрии режущей части инструмента введением заднего угла $\alpha$ уменьшает длину контакта. Это приводит к уменьшению тепловыделения и увеличению стойкости инструмента. Анализ температурного поля для зуба пилы с модифицированной геометрией проводится с использованием метода источников теплоты, включая отраженные источники теплоты [3].

Для расчета температуру на контактной поверхности в конце рабочего хода (за время контакта, $\tau=\tau_{\kappa}$ ) используется полученное ранее выражение для температуры на задней поверхности зуба для мгновенного полосового неподвижного источника тепла $[2,3]$.

Полученная зависимость позволяет определять температуру поверхности зуба, контактирующей с нагретой обрабатываемой поверхностью:

$$
T_{3}=\frac{T_{\kappa} \cdot \sqrt{\tau_{\kappa}}}{2 \sqrt{\tau}} \cdot \exp \left[-\frac{y^{2}}{4 \omega_{3} \cdot \tau}\right] \cdot\left(\Phi\left[\frac{x}{2 \sqrt{\omega_{3} \cdot \tau}}\right]-\Phi\left[\frac{x-l_{3}}{2 \sqrt{\omega_{3} \cdot \tau}}\right]\right),
$$

где $\Phi(x, \tau)$ - безразмерная функция ошибок, описывающая распределение температуры по ширине площадки контакта зуба [3]; $\omega_{3}$ - коэффициент температуропроводности материала пилы, $\mathrm{m}^{2} / \mathrm{c}[5] ; l_{3}$ - длина контактной площадки по задней грани зуба пилы, мм; $T_{\kappa}-$ температура контакта, ${ }^{\circ} \mathrm{C} ; x, y$ - координаты точки зуба пилы (рис. 1).

Для определения распределения температуры по высоте зуба пилы необходимо учесть влияние граничных поверхностей, приводящих полубесконечное тело к усеченной пирамиде. Введем две симметричные адиабатические границы, под углом $20^{\circ}$ к оси зуба (рис. 1).

Тепловой поток в зубе отражается от границ раздела, что увеличивает температуру. Для описания граничных условий на боковых поверхностях зуба воспользуемся методом отраженных источников теплоты.

Правый тепловой источник находится далеко от вершины инструмента и его влиянием можно пренебречь.

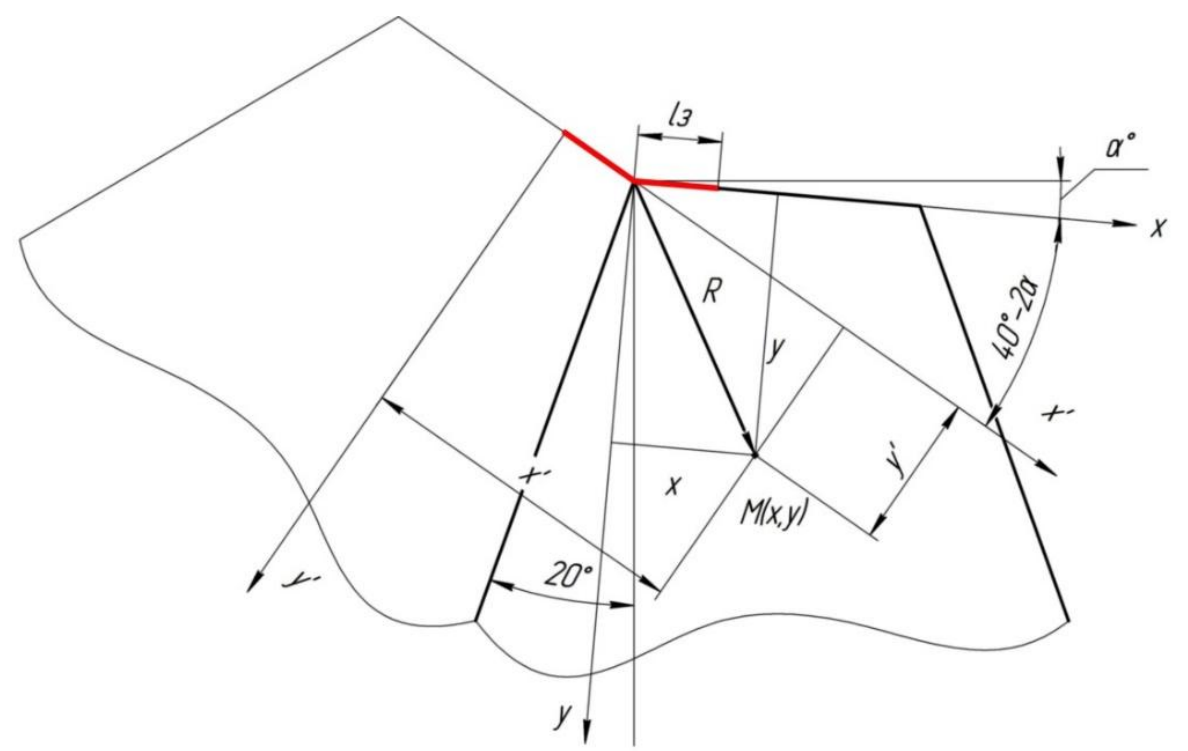

Рис. 1. Система координат зуба пилы и расположение левого фиктивного источника тепла 
Температура в точке $M(x, y)$ складывается из теплового потока на задней границе зуба пилы и фиктивного теплового потока от отраженного источника. Этот фиктивный источник расположен симметрично основному источни- ку относительно границы раздела (рис. 1).

Координаты точки $M$ в системе координат $\left(x^{\prime}, y^{\prime}\right)$ для левого фиктивного источника теплоты можно найти из выражений:

$$
\begin{aligned}
& x^{\prime}=R \cdot \cos \left(\operatorname{arctg} \frac{y}{x}-40-2 \alpha\right)+l_{3}=\sqrt{x^{2}+y^{2}} \cdot \cos \left(\operatorname{arctg} \frac{y}{x}-40-2 \alpha\right)+l_{3} \\
& y^{\prime}=R \cdot \sin \left(\operatorname{arctg} \frac{y}{x}-40-2 \alpha\right)=\sqrt{x^{2}+y^{2}} \cdot \sin \left(\operatorname{arctg} \frac{y}{x}-40-2 \alpha\right)
\end{aligned}
$$

Тепловой поток на задней границе зуба пилы рассчитывается по формуле (1). Фиктивный тепловой поток от отраженного источника учитывает изменение координат $\left(x^{\prime}, y^{\prime}\right)$, ко- торые находятся по формулам (2).

Суммарный тепловой поток найдется из формулы (3):

$$
\begin{aligned}
& T_{3}=\frac{T_{\kappa} \cdot \sqrt{\tau_{\kappa}}}{2 \sqrt{\tau}} \cdot\left\{\exp \left[-\frac{y^{2}}{4 \omega_{3} \cdot \tau}\right] \cdot\left(\Phi\left[\frac{x}{2 \sqrt{\omega_{3} \cdot \tau}}\right]-\Phi\left[\frac{x-l_{3}}{2 \sqrt{\omega_{3} \cdot \tau}}\right]\right)+\right. \\
& +\exp \left[-\frac{\left(\sqrt{x^{2}+y^{2}} \cdot \sin \left(\operatorname{arctg} \frac{y}{x}-40-2 \alpha\right)\right)^{2}}{4 \omega_{3} \cdot \tau}\right] \times \\
& \left.\times\left(\Phi\left[\frac{\sqrt{x^{2}+y^{2}} \cdot \cos \left(\operatorname{arctg} \frac{y}{x}-40-2 \alpha\right)+l_{3}}{2 \sqrt{\omega_{3} \cdot \tau}}\right]-\Phi\left[\frac{\sqrt{x^{2}+y^{2}} \cdot \cos \left(\operatorname{arctg} \frac{y}{x}-40-2 \alpha\right)}{2 \sqrt{\omega_{3} \cdot \tau}}\right]\right)\right\} .
\end{aligned}
$$

Для иллюстрации полученного решения в программе Excel была сформирована расчетная таблица и получено поле рапределения температур от нагрева зуба в начале цикла в момент времени $\tau=0,006$ с. Распределение температур по высоте зуба показано на рис. 2-8.

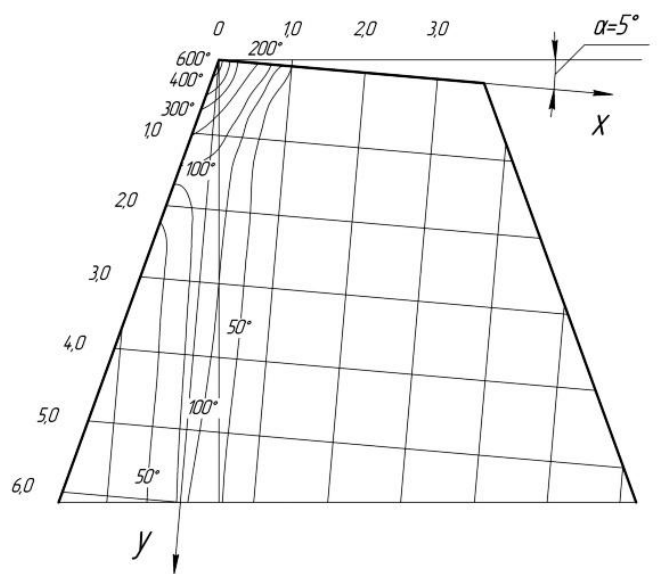

Рис. 2. Температурное поле зуба пилы в начальный момент времени при $\tau=0,002$ с
Анализ температурного поля показывает, что зуб пилы в начальный момент $(\tau=0,002 \mathrm{c}$, $\tau=0,004$ с) испытывает импульсное нагружение. Тепло быстро распространяется в тело пилы.

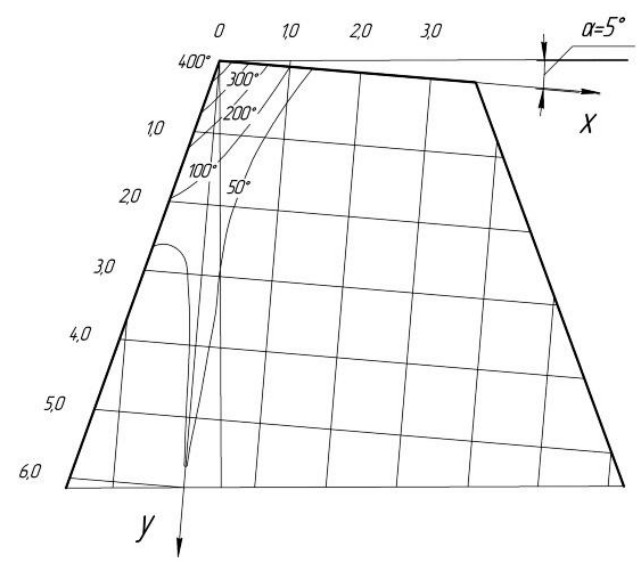

Рис. 3. Температурное поле зуба пилы в момент времени $\tau=0,004 \mathrm{c}$

При $\tau=0,02$ с температура задней поверхности уменьшается, боковые поверхности зуба 
нагреваются. Температурное поле выравнивается.

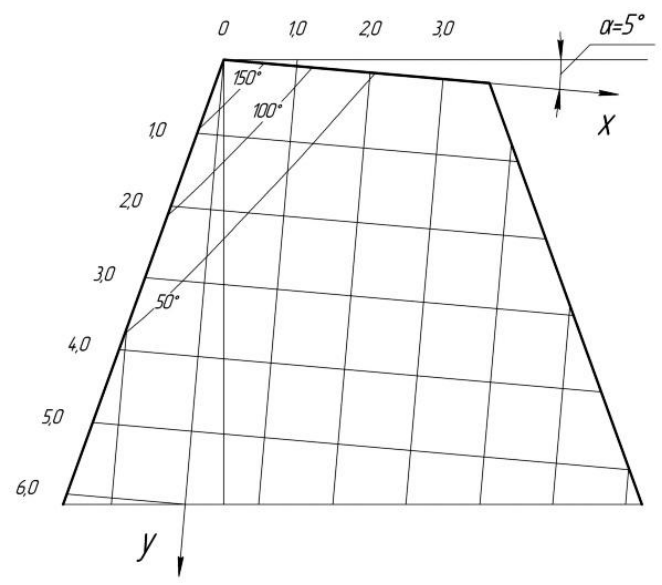

Рис. 4. Температурное поле зуба пилы в момент времени $\tau=0,02 \mathrm{c}$

В конце цикла и холостого хода при $\tau=0,06 \mathrm{c}$ вершина зуба охлаждается до температуры около $50{ }^{\circ} \mathrm{C}$. Затем начинается новый цикл нагрева, зуб пилы входит в контакт с обрабатываемой поверхностью.

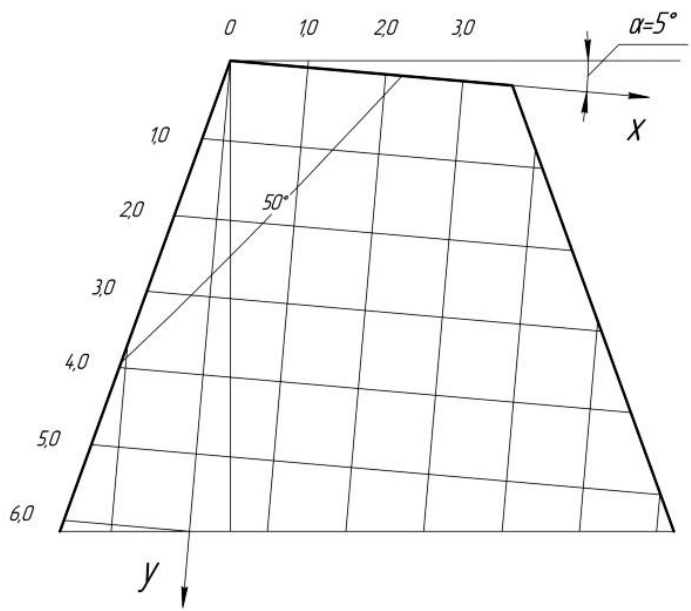

Рис. 5. Температурное поле зуба пилы в конце цикла (один оборот пилы) при $\tau=\tau_{d}=0,06 \mathrm{c}$

Для расчета температурного поля в зависимости от количества циклов $N$ необходимо учесть прерывистость процесса резания по известной зависимости [2]. Сначала определяется температурное поле в конце каждого цикла при $\tau=\tau_{d} \cdot N$.

$$
\begin{aligned}
& \Delta T_{3 N}=\frac{T_{\kappa} \cdot \sqrt{\tau_{\kappa}}}{2 \sqrt{\tau_{d} \cdot N}} \cdot\left\{\exp \left[-\frac{y^{2}}{4 \omega_{3} \cdot \tau_{d} \cdot N}\right] \cdot\left(\Phi\left[\frac{x}{2 \sqrt{\omega_{3} \cdot \tau_{d} \cdot N}}\right]-\Phi\left[\frac{x-l_{3}}{2 \sqrt{\omega_{3} \cdot \tau_{d} \cdot N}}\right]\right)+\right. \\
& +\exp \left[-\frac{\left(\sqrt{x^{2}+y^{2}} \cdot \sin \left(\operatorname{arctg} \frac{y}{x}-40-2 \alpha\right)\right)^{2}}{4 \omega_{3} \cdot \tau_{d} \cdot N}\right] \times \\
& \left.\times\left(\Phi\left[\frac{\sqrt{x^{2}+y^{2}} \cdot \cos \left(\operatorname{arctg} \frac{y}{x}-40-2 \alpha\right)+l_{3}}{2 \sqrt{\omega_{3} \cdot \tau_{d} \cdot N}}\right]-\Phi\left[\frac{\sqrt{x^{2}+y^{2}} \cdot \cos \left(\operatorname{arctg} \frac{y}{x}-40-2 \alpha\right)}{2 \sqrt{\omega_{3} \cdot \tau_{d} \cdot N}}\right]\right)\right\} .
\end{aligned}
$$

Затем определяется суммарный нагрев поверхности зуба пилы от всех $N$ циклов [2]:

$$
\Delta T_{3 N_{\Sigma}}=\Delta T_{3_{1}}+\Delta T_{3_{2}}+\Delta T_{3_{3}}+\ldots+\Delta T_{3_{N}} .
$$

Распределение температур по высоте зуба для $N=5$ показано на рис. 6. Вершина зуба пилы нагрелась до $250^{\circ} \mathrm{C}$ на расстояние около $1 \mathrm{mм.}$

Расчет температурного поля для 10 циклов (рис. 7) показал, что вершина нагревается до $300{ }^{\circ} \mathrm{C}$, а основание зуба до $150{ }^{\circ} \mathrm{C}$.

С увеличением продолжительности реза температура вершины зуба постепенно стабилизируется. На рис. 8 показано распределение температуры через 50 оборотов пилы. Поверхность контакта нагревается выше $350{ }^{\circ} \mathrm{C}$.

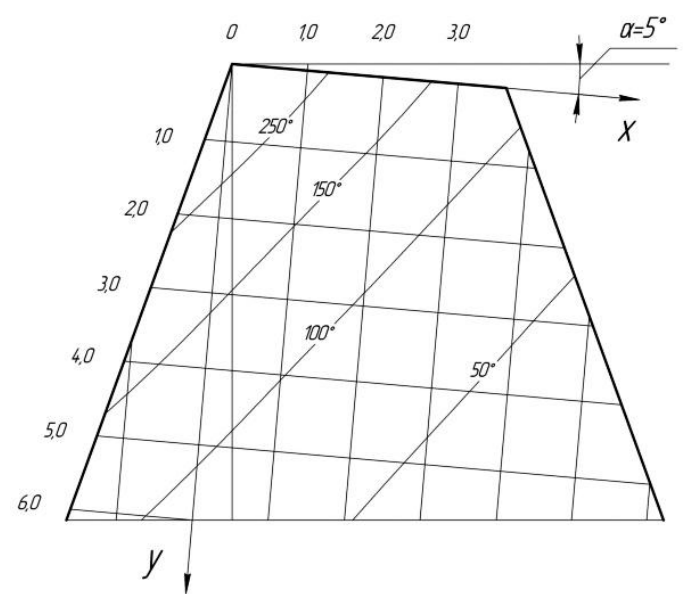

Рис. 6. Температурное поле зуба пилы после пяти оборотов при $\tau=0,3 \mathrm{c}$ 


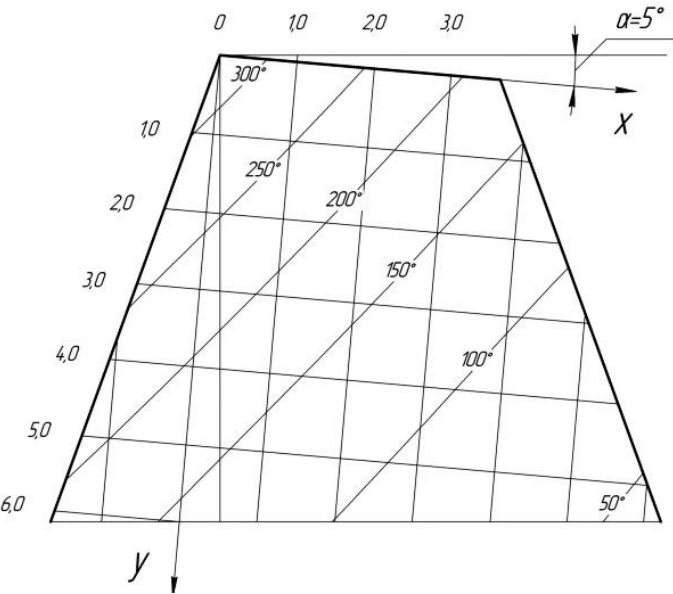

Рис. 7. Температурное поле зуба пилы после десяти оборотов при $\tau=0,6 \mathrm{c}$

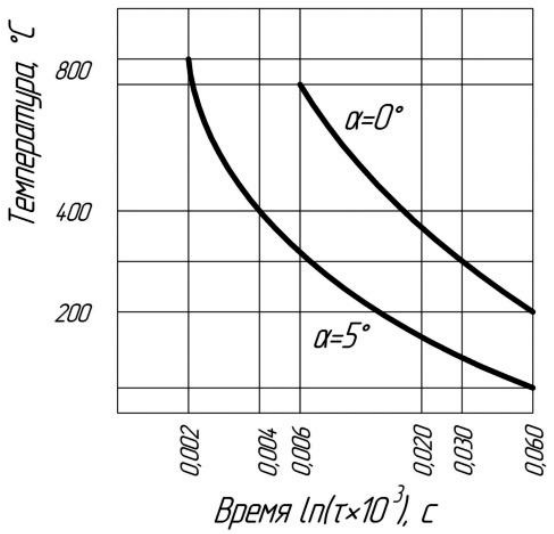

$a$

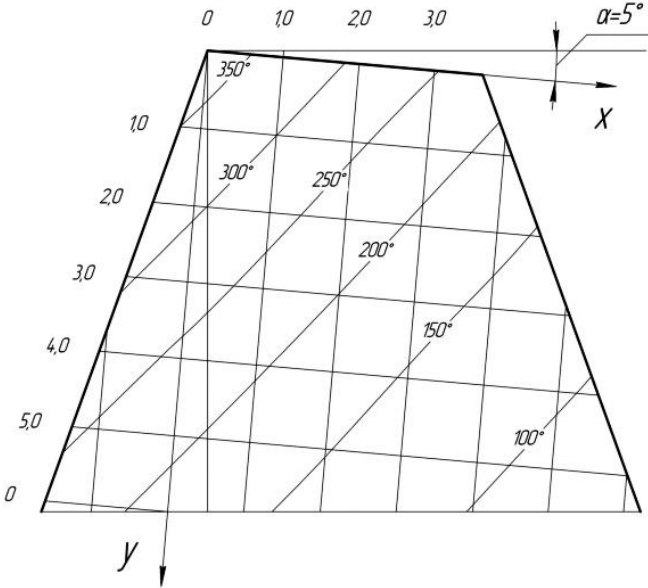

Рис. 8. Температурное поле зуба пилы после пятидесяти оборотов при $\tau=3 \mathrm{c}$

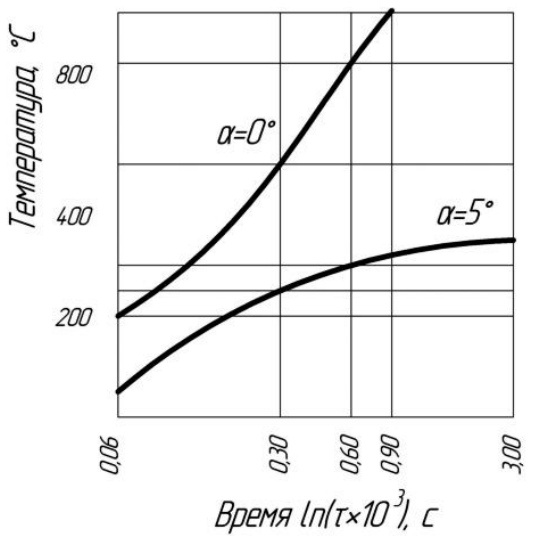

6

Рис. 9. Максимальная расчетная температура зуба:

$a$ - охлаждение за один оборот пилы; $\sigma$ - нагрев за 50 оборотов

На рис. 9 представлено изменение максимальной расчетной температуры зуба в зависимости от времени реза для пил с модифицированной $\left(\alpha=5^{\circ}\right)$ и с традиционной геометрией.

\section{Выводы}

Сравнительный анализ максимальной температуры рабочей поверхности зуба с модифицированной и с традиционной геометрией [2] показал, что введение заднего угла $\alpha$ значительно уменьшает площадку контакта и снижает нагрев вершины зуба пилы.

\section{БИБЛИОГРАФИЧЕСКИЙ СПИСОК}

1. Thermofrictional pipe cutting / Ю. Н. Полянчиков, А. И. Курченко, А. И. Банников, О. А. Макарова, А. А. Бан- ников // Russian Engineering Research. - 2010. - Vol. 30, № 7. - С. 745-746.

2. Исследование распределения тепла в зубе пилы с учетом периодичности процесса при пакетной резке холодного металлопроката / А. И. Банников, О. А. Макарова, И. С. Ширяев, А. Д. Осипов // Известия ВолгГТУ : научный журнал № 8 (243) / ВолгГТУ. - Волгоград, 2020. (Серия «Прогрессивные технологии в машиностроении»). C. 7-13.

3. Резников, A. Н. Теплофизика процессов механической обработки материалов / А. Н. Резников. - М. : Машиностроение, 1981. - 279 с.

4. Коновалов, А. В. Теория сварочных процессов / А. В. Коновалов [и др.]. - М. : Изд-во МГТУ им. Н. Э. Баумана, 2007.

5. Чиркин, В. С. Теплофизические свойства материалов / В. С. Чиркин. - Рипол Классик, 2013. 
УДК 67.05

DOI: $10.35211 / 1990-5297-2021-8-255-14-16$

\author{
Ц. А. Батуев, М. С. Шатов, К. Д. Лисов, Е. Д. Семенов
}

РАЗРАБОТКА УСТАНОВКИ ДЛЯ ГОРЯЧЕГО ФОРМОВАНИЯ

АВИАЦИОННОГО ОСТЕКЛЕНИЯ ИЗ ОРГАНИЧЕСКОГО СТЕКЛА С ПРИМЕНЕНИЕМ АДДИТИВНЫХ ТЕХНОЛОГИЙ

Восточно-Сибирский государственный университет технологий и управления

E-mail: batuevc@mail.ru

В настоящей статье рассматриваются вопросы усовершенствования технологии горячей формовки деталей авиационного остекления из органического стекла с помощью современных методов аддитивных технологий, актуальность разработки и внедрения данной технологии на производстве.

Ключевые слова: горячее формование, авиационное остекление, органическое стекло, аддитивные технологии.

\title{
Ts. A. Batuev, M. S. Shatov, K. D. Lisov, E. D. Semenov
}

\section{DEVELOPMENT OF MACHINE FOR HOT FORMING OF AVIATION GLAZING FROM ORGANIC GLASS USING ADDITIVE TECHNOLOGIES}

\section{East Siberia State University of Technology and Management}

This article discusses the issues of improving hot forming technology of aviation glazing parts from organic glass using modern methods of additive technologies, relevance of development and implementation of this technology in production.

Keywords: hot forming, aviation glazing, organic glass, additive technologies.

Существующие технологии изготовления авиационного остекления из органического стекла в большинстве своем не отвечают требованиям и потребностям современного машиностроения. Они отличаются дороговизной в изготовлении оснастки и конечной продукции, разнообразностью подходов к методу изготовления деталей, жесткими ограничениями по форме и размерам получаемых деталей для каждой отдельной технологии, нестабильностью качества деталей по оптическим свойствам. Одним из самых дорогостоящих элементов в существующих технологиях является технологическая оснастка. В большинстве случаев она изготавливается из алюминиевых сплавов Д16, Д16Т, АК4. Для изготовления оснастки из алюминиевых сплавов необходимо использовать крупногабаритные заготовки, подвергать их длительной механической обработке и достигать шероховатости рабочей поверхности $\mathrm{Ra}$ 0,3-0,8 микрометров. Высокая стоимость изготовления технологической оснастки для формования органических стекол и ее высокая трудоемкость влияет на конечную стоимость продукции. Так же, высокие технологические требования к оснастке предполагают наличие большого количества доводочных работ. Необходимо максимально отходить от слесарных и доводочных операций, сокращать время изготовления одной детали или партии [1].

На сегодняшний момент технология производства вакуумным формованием по матрице деталей из органического стекла применяется, если детали нужно придать сложную форму, которую получить системой пуансон-матрица практически невозможно или требует больших затрат на изготовление. Вакуумное формование позволяет получать детали сложной формы с приемлемой точностью и без потери оптических свойств стекла. Наличие системы создания вакуума, необходимость выкладки поверхности матрицы дорогими материалами (замша, кожа) для предотвращения появления отпечатков на поверхности детали, и высокая стоимость обслуживания сводит на нет все преимущества. Так же данный способ требует особого расположения каналов для выхода воздуха. Изготовление подобной оснастки из металлических материалов, даже с использованием современных методов металлообработки, понижает общую технологичность. Особенности традиционного технического оснащения так же проявляются в момент охлаждения. Изза разницы коэффициентов линейного расширения, усадки органического стекла и разницы теплоемкости, детали в местах закрепления

(С Батуев Ц. А., Шатов М. С., Лисов К. Д., Семенов Е. Д., 2021. 
и местах набольших изгибов подвергаются эффекту гофрообразования (появления складчатой поверхности), что мгновенно приводит к забраковке детали [2].

Так же необходимо учесть, что большая часть используемого оборудования для формования остекления, начинает морально и технически устаревать, зачастую такое оборудование после выхода из строя становится неремонтопригодно.

Целью нашей работы является усовершенствование существующих технологий производства авиационного остекления из органического стекла, внедрение современных аддитивных технологий в создание формовочной оснастки, разработка автоматизированного оборудования и оснастки, на котором можно изготавливать изделия из органического стекла с высокой точностью и производительностью. Применение неметаллической оснастки, получаемой с помощью современных аддитивных технологий и FDM-печати позволит значительно сократить расход материала, существенно снизить конечный вес оснастки, уменьшить время ее изготовления, позволит изготавливать геометрически сложные формы, недоступные для традиционных методов механической обработки. Печать пластика при изготовлении оснастки позволяет получить прочные износостойкие изделия с сравнительно низкой стоимостью материалов и широкими возможностями пост- обработки. Получаемая оснастка будет обладать достаточными свойствами, необходимыми для традиционного метода вакуумного формования, такими как прочность, износостойкость, теплостойкость.

Исходя из вышеуказанных целей перед нами были поставлены следующие задачи:

- разработка технологии вакуумного формования на штамповой оснастке, изготовленной из 3D пластика;

- создание экспериментальной установки;

- проведение научных экспериментов, установление влияния конструкторско-технологических факторов на процесс формообразования;

- обеспечение стабильности получения требуемых размеров и формы детали;

- обеспечение требуемых оптических свойств детали.

Широко используемое в настоящее время в авиационной промышленности органическое стекло марок $\mathrm{AO}$ и СО применяется в изготовлении деталей с помощью традиционных методов производства, включающих большое применение ручного труда. Такой метод увеличивает влияние человеческого фактора на конечное качество продукции и повышает вероятвероятность появления брака. Автоматизация процесса в проектируемой установке сокращает участие человека и влияние человеческого фактора в технологическом процессе, тем самым повышая качество продукции [3].
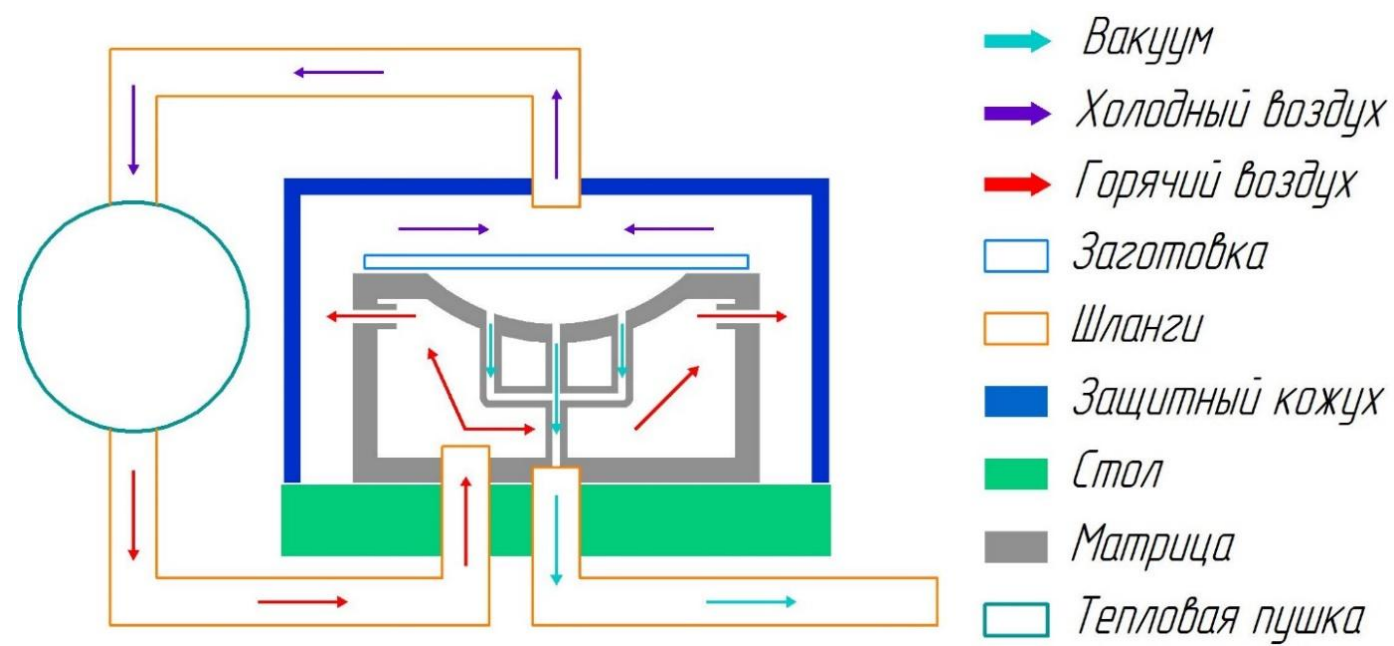

Установка для горячего формования авиационного остекления из органического стекла

Проектируемая установка, представленная на рисунке, будет состоять из формовочной камеры, системы нагрева и циркуляции воздуха, вакуумного насоса и системы управления с подключением к ПК.
В предлагаемой установке, мы планируем проводить нагрев заготовки с помощью горячего воздуха, который будет проходить через пустотелую матрицу. Для некоторых высокопрочных марок органического стекла необхо- 
димо достаточно быстро получать необходимую температуру в камере $\left(120-180{ }^{\circ} \mathrm{C}\right)$ для размягчения стекла. В данном случае можно дополнительно оснастить установку лампами инфракрасного нагрева [4].

Оснастка, полученная печатью 3D пластиком, должна выдерживать температуру свыше $120{ }^{\circ} \mathrm{C}$. На текущий момент ведутся исследования по подбору различных 3D пластиков под конкретные марки органического стекла, по выработке рекомендаций по их применению.

На основании вышеизложенного можно сделать вывод о том, что разработанная нами оригинальная конструкция установки для горячего формования авиационного остекления из органического стекла, позволит формовать детали, сохранив все необходимые предъявляемые требования к нему, сократив стоимость и время изготовления.

\section{БИБЛИОГРАФИЧЕСКИЙ СПИСОК}

1. Бортников, В. Г. Теоретические основы и технология переработки пластических масс : учеб. - 3 изд. / В. Г. Бортников. - М. : НИЦ ИНФРА-М, 2015.

2. Гудимов, М. М. Органическое стекло / М. М. Гудимов, Б. В. Петров. - М. : Химия, 1981.

3. Стрельияов, $K . H$. Технология изготовления изделий из органического стекла / К. Н. Стрельцов, Б. И. Лосев, Н. А. Сидоров. - Л. : Машиностроение, 1984.

4. Горелов, Ю. П. Новые органические стекла для авиастроения / Ю. П. Горелов, Т. Г. Чмыхова, И. А. Шалагинова // Пластические массы. - 2009. - № 12.

\title{
А. Э. Вирт, А. П. Иващценко
}

\section{ИЗМЕНЕНИЕ КОНСТРУКЦИИ РАСКАТЫВАЮЩЕГО ИНСТРУМЕНТА, ПОВЫШАЮЩЕЕ ЕГО НАДЕЖНОСТЬ}

\author{
Камышинский технологический институт (филиал) \\ Волгоградского государственного технического университета
}

E-mail: virt@kti.ru

Процесс поверхностного пластического деформирования роликами сопровождается значительными силами, действующими через деформирующий элемент на обрабатываемую поверхность. Эти силы вызывают качественные и структурные изменения в поверхностном слое. Для создания сил деформирования в инструменте используются центробежные силы, возникающие при вращении инструмента от массивных рычагов, которые, в свою очередь, воздействуют на деформирующие ролики. Во избежание произвольного смещения инерционных рычагов и как следствие смещения деформирующих роликов и нарушения заданных размеров при обработке необходимо уделить должное внимание способу их крепления. Способ крепления данных инерционных рычагов и способ крепления деформирующих роликов в инерционном раскатнике и рассматривается в данной статье.

Ключевые слова: ППД, поверхностное пластическое деформирование роликами, самоподача, ППД роликами.

\section{A. E. Virt, A. P. Ivashchenko}

\section{IMPROVING DESIGN PARAMETERS INERTIA LEVER IS ROLLED DEVICES}

\section{Kamyshin Technology Institute (branch) of the Volgograd State Technical University, Kamyshin, Russia}

He process of surface plastic deformation is accompanied by significant forces acting through the deforming element on the surface. These forces cause the quality and structural changes in the surface layer. To create a strain force in the tool used centrifugal forces generated during rotation of the tool from massive arms. Which, in turn, affect the deforming rollers. In order to prevent arbitrary displacement of the inertial instruments and as a result of displacement of the deforming rollers and the violation of specified sizes in the processing is necessary to pay due attention to their mountings. Method of attachment data inertial instruments and method of attachment of the deforming rollers and the inertial raskatnike covered in this article.

Keywords: surface working, surface plastic deformation, self-feeding, combined machine processing, SPD by rollers.

(C) Вирт А. Э., Иващенко А. П., 2021. 
При обработке деталей поверхностным пластическим деформированием в большинстве применяемых для раскатывания инструментах, в качестве рабочей поверхности деформирующих элементов, применяются тела, имеющие форму шара, тора или прямого кругового конуca [1-5].Одной из задач при выборе конструктивных параметров деформирующего элемента является набортаких параметров, при которых между контактирующими поверхностями элементов и детали будут действовать минимальные контактные напряжения, что в свою очередь повышает надежность и долговечность инструмента.

В различных конструкциях раскатников применяются два варианта контакта роликов с опорными элементами (рис. 1).

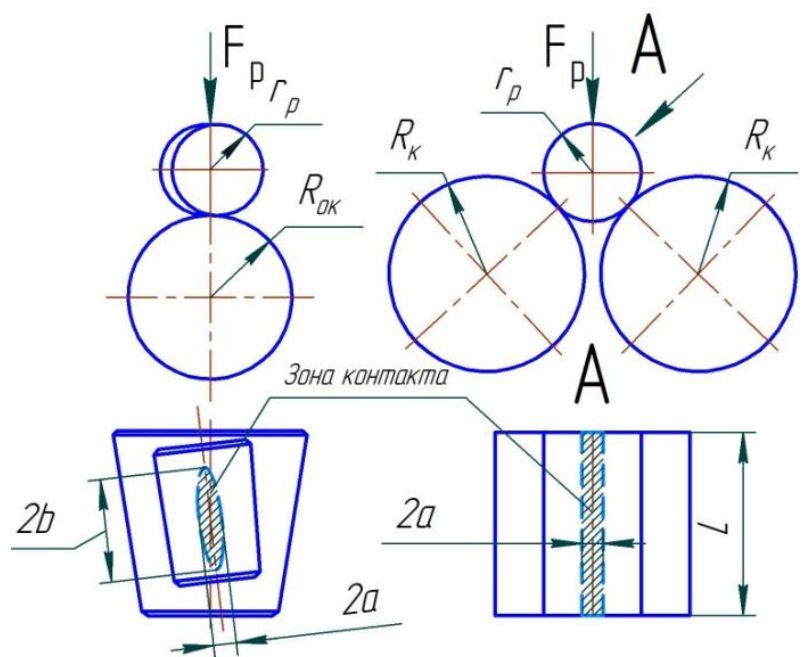

На опорныப конуг

Ha dba kamka

$a$

$\sigma$

Рис. 1. Различные варианты контакта роликов с опорными элементами
В первом варианте сила деформирования передается на деформирующий ролик через опорный конус (рис. $1, a$ ). При значительных силах деформирования между опорными поверхностями ролика и конуса возникают значительные контактные напряжения и проскальзывание, что вызывает повышенный износ ролика и конуса. Поэтому, одним из наиболее эффективных способов минимизации проскальзывания является применение цилиндрического деформирующего ролика, опирающегося на несколько цилиндрических опорных катков, как показано во втором варианте (рис. 1, б). Использование опорных катков и деформирующих роликов, имеющих цилиндрическую форму наружной поверхности и установленных под углом самозатягивания, обеспечивает равномерную самоподачу инструмента и равнозначную скорость их вращения по всей длине контакта, что существенно снижает износ опорных элементов раскатывающего устройства и улучшает стабильность процесса ППД. Второй вариант (рис. 1, б) предпочтительней, так как существенно расширяет технологические возможности раскатников. Однако, при номинальном значении силы деформирования контактные напряжения зачастую превышают допустимые значения даже при установке цилиндрических деформирующих роликов на два опорных катка, поэтому дальнейшее совершенствование методов установки деформирующих роликов привело к идее устанавливать деформирующие ролики в обоймы (рис. 2).

В таком случае напряжения от сил деформирования распределяются по всей нижней поверхности деформирующего ролика, а по величине будут составлять не более 3 \% от контактных напряжений, возникающих при контакте двух цилиндрических катков $[6,7]$.

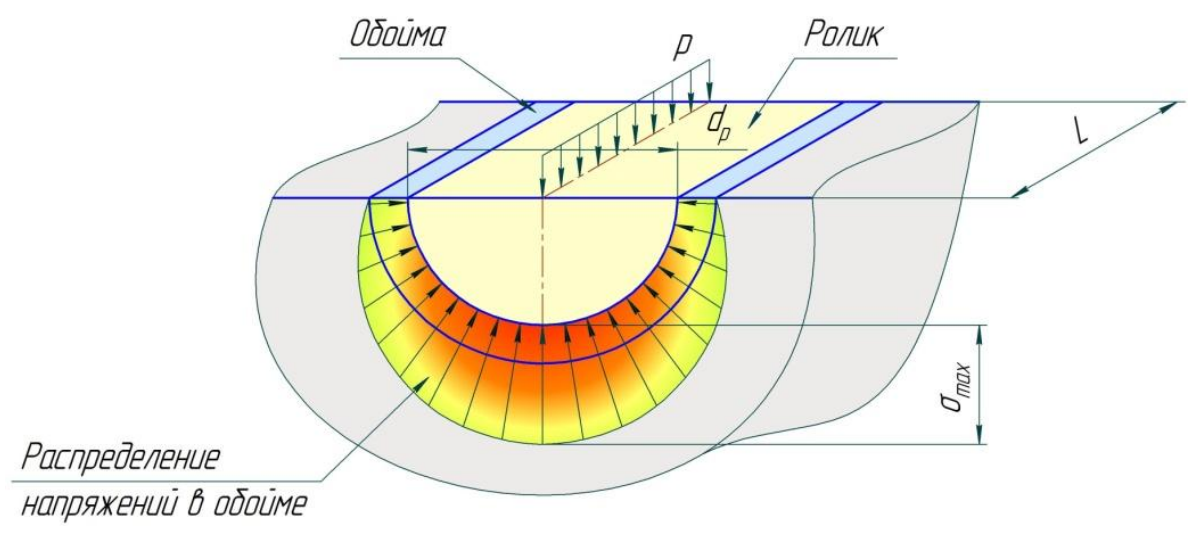

Рис. 2. Распределение напряжений в обойме от деформирующего цилиндрического ролика 
Цилиндрические деформирующие ролики и обоймы могут быть установлены в корпусе раскатника на инерционные рычаги (рис. 3), у которых форма поперечного сечения выполнена в виде кругового сектора, что позволяет наиболее рационально использовать все полезное пространство в радиальном сечении раскатника. При вращении раскатника приведенная масса инерционных рычагов оказывает существенное влияние на величину силы деформиро- вания. Увеличение массы инерционного рычага позволяет существенно снизить скорость вращения инерционного рычажного раскатывающего устройства, не уменьшая при этом заданной силы деформирования. Конструктивные параметры поперечного сечения инерционных рычагов зависят от диаметра обрабатываемого отверстия, поэтому определение их рациональной расчетной массы осуществляется за счет варьирования длины рычага и его количества.

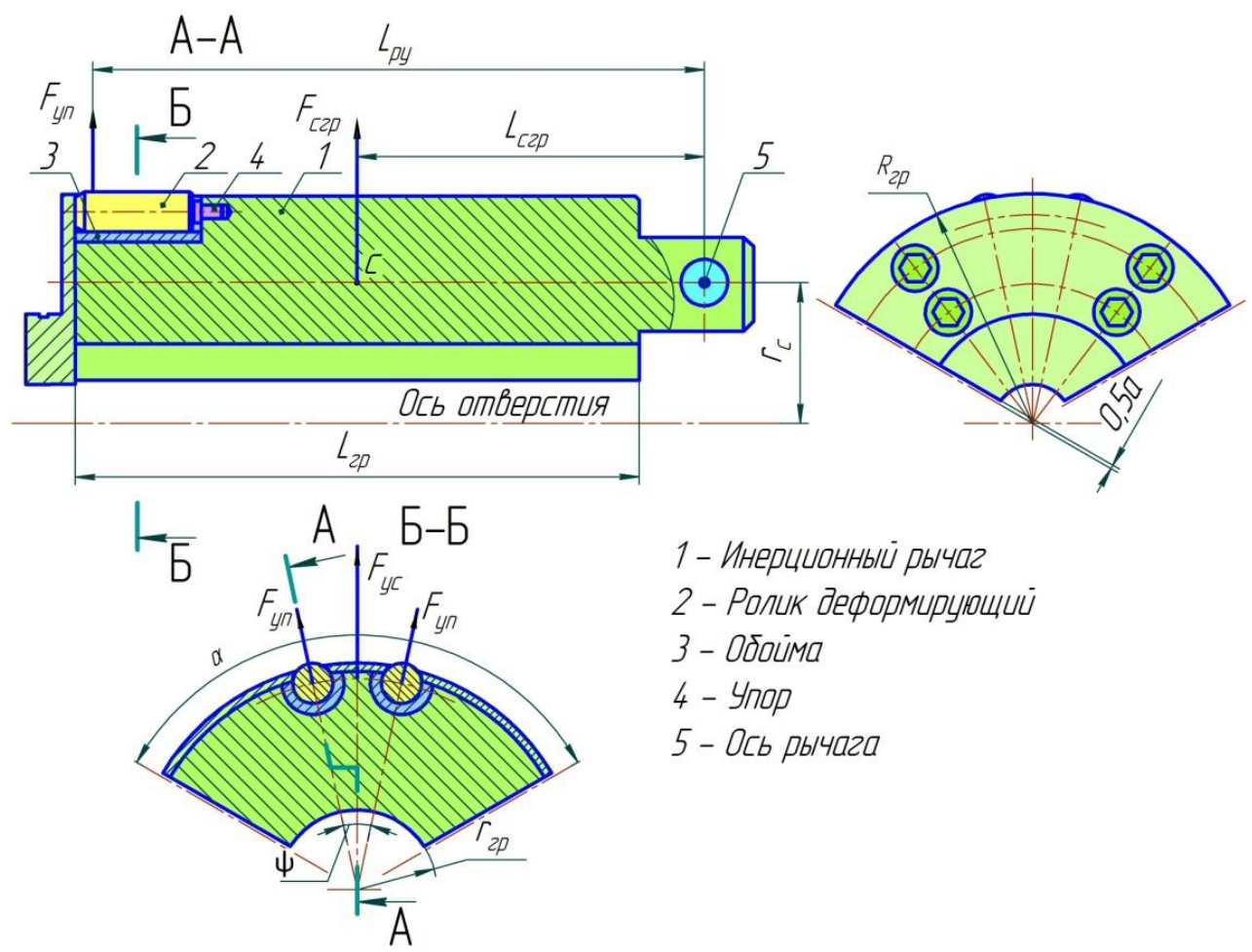

Рис. 3. Расчетная схема определения силы деформирования: $A$ - зазор между смежными опорными катками

Ниже приведена разработанная методика для определения влияния размеров инерционного рычага на силу деформирования.

Центробежные силы $F_{y n}$ при одном деформирующем ролике 2 в инерционном рычаге 1 (рис. 3) могут быть вычислены по формуле

$$
F_{y n}=\frac{F_{c z p} \cdot L_{c z p}}{L_{p y}} .
$$

Центробежная сила $F_{y n}$ при двух роликах 2 в инерционном грузе, действующая на каждый из роликов рассчитывается по формуле

$$
F_{y n}=\frac{F_{c z p} \cdot L_{c 2 p}}{2 \cdot L_{p y} \cdot \cos (\psi / 2)},
$$

где $\psi$ - угол между смежными деформирующими роликами, расположенными в инерционном грузе; $F_{c г p}$ - центробежная сила, приложенная к центру тяжести инерционного рычага;
$L_{c г p}$ - расстояние от оси поворота инерционного рычага до его центра тяжести; $L_{p y}$ - расстояние от оси поворота инерционного рычага до точки приложения силы деформирования на деформирующем ролике.

Центробежная сила $F_{c г p}$, приложенная к центру тяжести инерционного рычага

$$
F_{c г p}=\frac{4 \cdot \pi^{2} \cdot m_{2 p} \cdot r_{c} \cdot n^{2}}{3600},
$$

где $m_{z p}$ - масса инерционного рычага; $r_{c}$ - радиус расположения центра тяжести инерционного рычага от оси отверстия; $n$ - частота вращения инерционного рычажного раскатывающего устройства.

Масса инерционного рычага определяется по формуле

$$
m_{\imath p}=\frac{\pi \cdot \alpha}{360}\left(R_{z p}^{2}-r_{z p}^{2}\right) \cdot L_{z p} \cdot \rho,
$$


где $\alpha$ - угол сектора инерционного рычага; $R_{z p}, r_{2 p}$ - наружный и внутренний радиусы инерционного рычага соответственно; $L_{2 p}$ - расчетная длина инерционного рычага; $\rho$ - плотность материала инерционного рычага.

Контактные напряжения между роликом и опорным конусом при опоре на обойму можно определить на основе применения фундаментального решения теории упругости [7]. Это решение основано на положении, что приложенная сила к поверхности полубесконечного тела вызывает на вырезанном в поверхности цилиндра напряжение, которое можно вычислить по формуле

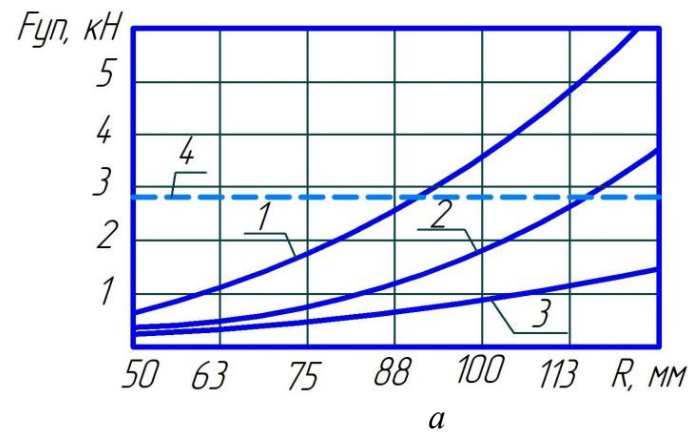

$$
\sigma=\frac{2 \cdot F_{c 2 p}}{\pi \cdot r_{p}}
$$

Контактные напряжения между роликом и опорным конусом

$$
\sigma=0,59 \sqrt{F_{y n} \cdot E_{n p} \cdot \frac{D_{\kappa}+d_{p}}{D_{\kappa} \cdot d_{p}}},
$$

где $D_{\kappa}$ и $d_{p}$ - диаметр конуса и диаметр ролика соответственно; $E_{n p}$ - приведенный модуль упругости материала конуса и ролика.

На графиках (рис. 4) показаны зависимости изменения сил деформирования от радиусов обрабатываемых отверстий и частот вращения раскатника.

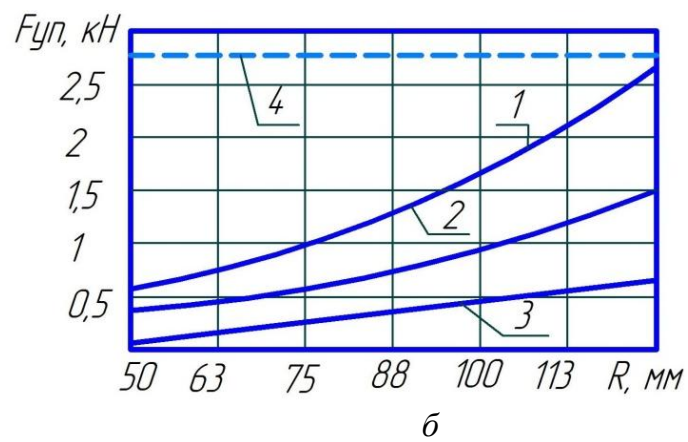

Рис. 4. Зависимости изменения силы деформирования от радиусов обрабатываемых отверстий для диаметров деформирующих роликов 12 мм:

кривая $1-\mathrm{n}=900$ мин $^{-1}$; кривая $2-\mathrm{n}=1200$ мин $^{-1}$; кривая $3-\mathrm{n}=1500$ мин $^{-1}$; прямая $4-$ необходимая сила деформирования 2,8 кН; $a$ - один ролик в инерционном рычаге; $\sigma$ - два ролика в инерционном рычаге

На графиках (рис. 5) представлены зависимости по контактным напряжениям между ро-

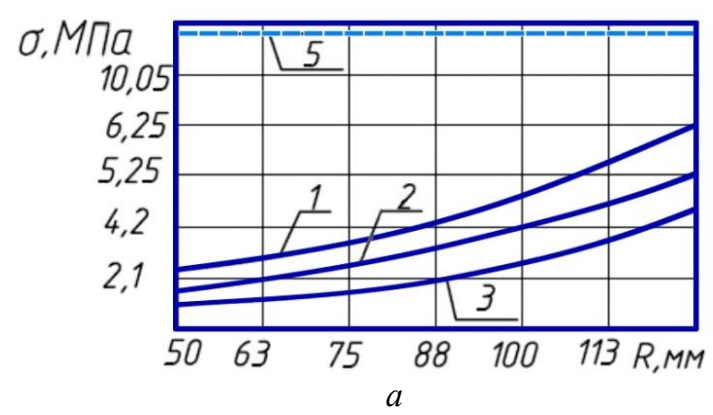

ликом и опорным конусом (рис. 5, a), между роликом и обоймой (рис. 5,6$)$.

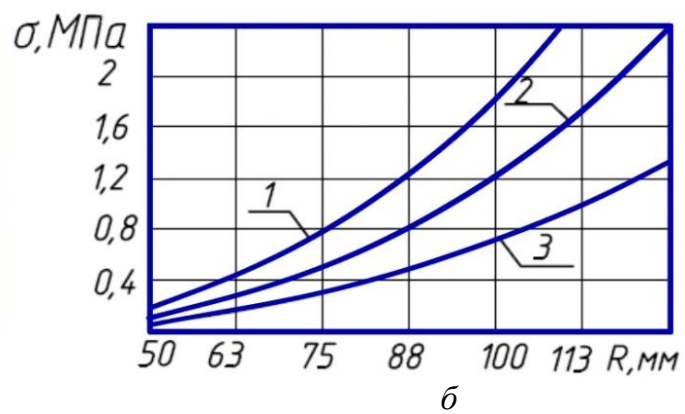

Рис. 5. Изменение контактных напряжений от диаметров обрабатываемых отверстий для диаметров деформирующих роликов 12 мм:

кривая $1-\mathrm{n}=900$ мин $^{-1}$; кривая $2-\mathrm{n}=1200$ мин $^{-1}$; кривая $3-\mathrm{n}=1500$ мин $^{-1}$; прямая 4 - допускаемое касательное напряжение; $a$ - контакт ролика с опорным конусом; $\sigma$ - контакт ролика с обоймой

Проанализировав графики на рис. 4 и 5 можно сделать важные выводы для определения рациональных конструктивных параметров вращающегося раскатника: необходимое усилие деформирования для радиусов обрабатываемых отверстий меньше 100 мм достигается при частоте вращения раскатника больше 1500 мин $^{-1}$, что не рекомендуется т. к. будет приводить к большому износу инструмента и шуму при работе; при установке роликов в обойму контактные напряжения примерно в пять раз ниже, чем напряжения, когда ролики опираются на опорный конус. Небольшие величины напряжений (рис. 5, б) в процессе использования ин- 
струмента приводят к многократному повышению его надежности.

На основании полученных данных разработана конструкция вращающегося раскатника для обработки отверстий поверхностным пластическим деформированием, которая представлена на рис. 6.

Раскатник вращающийся (рис. 6) состоит из оправки 1, трех инерционных рычагов 2, в которых располагаются обоймы 3 в количестве шести штук с расположенными в них деформирующими роликами 4. Для создания необходимого усилия деформирования каждый из трех рычагов 2 имеет возможность поворота относительно оси 5.

Для надежного центрирования раскатника в процессе его работы относительно оси обрабатываемого отверстия предусмотрен направляющий узел 6 , установленный на подшипниках 7, причем на наружной поверхности узла 6 закреплены направляющие шпонки 8, обеспечивающие базирование раскатника по отверстию.

При работе раскатника инерционные рычаги 2 с расположенными в них обоймами 3 и деформирующими роликами 4 под воздействием центробежной силы перемещаются относительно оси 5 в радиальном направлении и производят упругопластическое деформирование обрабатываемой поверхности отверстия.

Таким образом, разработанный инструмент позволяет получать расчетные усилия деформирования, приложенные к деформирующим роликам 4, как сумму моментов от величин центробежных сил, обеспечиваемых массами инерционных рычагов 2, на расчетные длины плеч, то есть расстояний по длине рычага от центров тяжести деформирующих роликов 7 и самих инерционных рычагов 2 до их крепления в шарнире 5 .
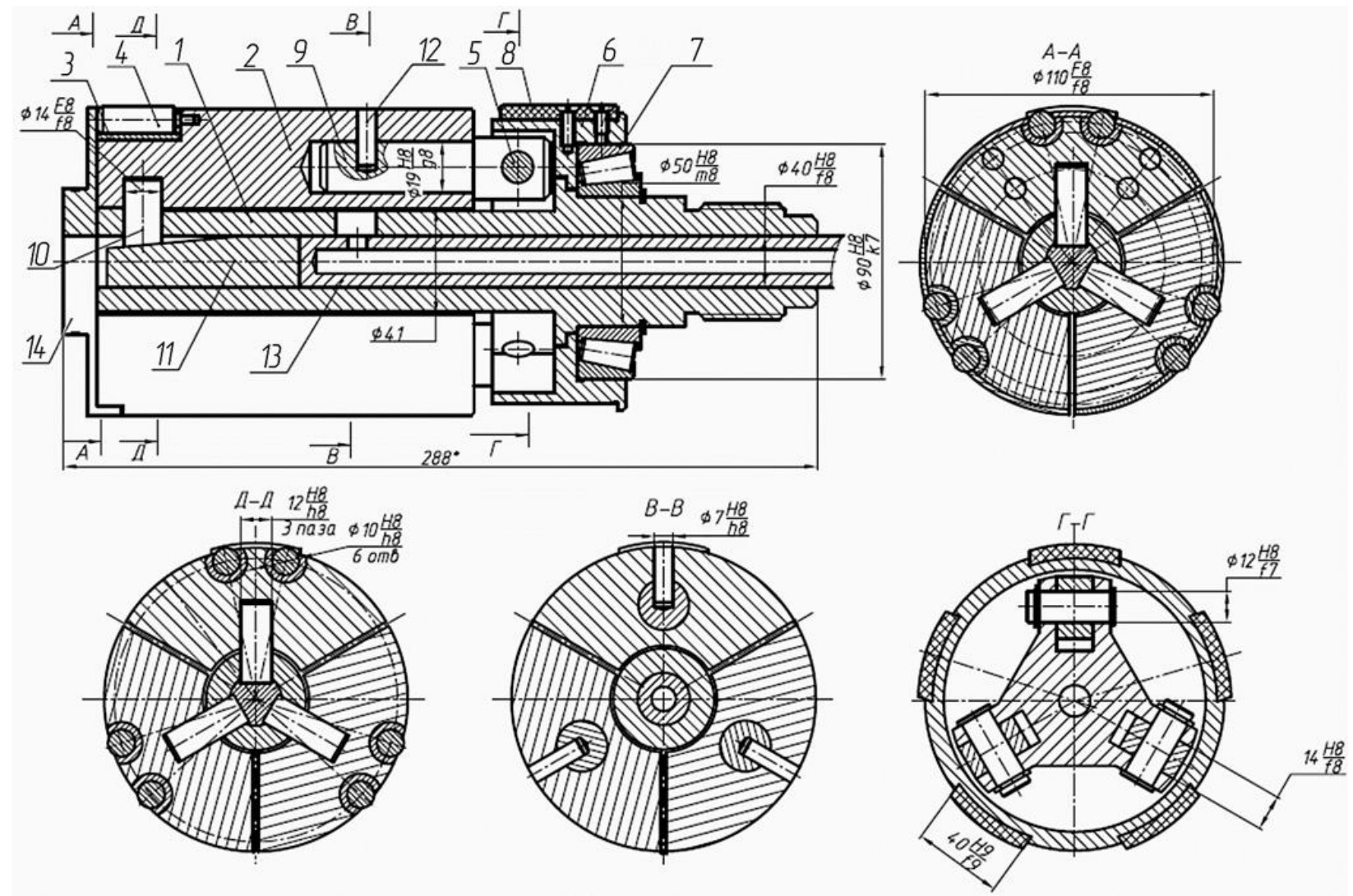

Рис. 6. Раскатник вращающийся:

1 - оправка; 2 - инерционный рычаг; 3 - обойма; 4 - деформирующий ролик; 5 - ось; 6 - направляющий узел; 7 - подшипник; 8 - направляющие шпонки; 9, 10 - вставка; 11 - упор; 12 - штифт; 13 - стержень толкающий; 14 - крышка

Также хотелось отметить, что в раскатнике, представленном на рис. 6, деформирующие ролики 4 размещены в обоймах 3 по всей ее внутренней поверхности, при этом контактные напряжения по сравнению с опорой на цилиндри- ческие катки, как это предусмотрено в других вариантах раскатниках, имеют значительно меньшие значения. За счет такого расположения роликов повышается усталостная прочность и долговечность опорного элемента, то 
есть обоймы 3. Кроме того, наличие трех инерционных рычагов 2 вместо пяти рычагов в большинстве конструкций существующих раскатников позволило увеличить массу инерционного рычага, а это в свою очередь привело к снижению необходимой частоты вращения при сохранении необходимого усилия обработки.

\section{БИБЛИОГРАФИЧЕСКИЙ СПИСОК}

1. Sevostyanov A. S., Bobrovskij I. N., Lukyanov A. A. (2014) Research of surface plastic deformation processing methods in Russia. ISJ Theoretical \& Applied Science 8 (16): 24-29. doi: http://dx.doi.org/10.15863/TAS.2014.08.16.3.

2. Marchenko, D., Artyukh, V., \&Matvyeyeva, K. (2020). Analysis of the influence of surface plastic deformation on increasing the wear resistance of machine parts. ProblemsofTribology, 25(2/96), 6-11https://doi.org/10.31891/2079-13722020-96-2-6-11.

3. Oteny, Y., Kazak, V., \&Morozova, E. (2017). Determination of Geometrical Parameters Contact Zone for Detail
Machining Surface Plastic Deformation. ProcediaEngineering, 206 .doi: 10.1016/j.proeng.2017.10.665

4. Рубахин, А. И. Комбинированный инструмент для обработки глубоких отверстий роликов машины непрерывного литья заготовок / А. И. Рубахин // Технические науки: традиции и инновации : матер. I Междунар. науч. конф. - Челябинск : Два комсомольца, 2012. - С. 132-136.

5. Древаль, A. E. Режуще-деформирующая обработка глубоких отверстий роликов машины непрерывного литья заготовок комбинированным инструментом / А. Е. Древаль, А. И. Рубахин // Вестник машиностроения. - 2013. № 10. - С. 58-61.

6. Смольников, Н. Я. Анализ геометрических соотношений площади контакта между роликом и деталью при поверхностном пластическом деформировании / Н. Я. Смольников, Я. Н. Отений, Н. В. Ольштынский, С. Н. Ольштынский // Прогрессивные технологии в машиностроении : межвуз. сб. науч. тр. / под ред. В. М. Оробинского ; ВолгГТУ. - Волгоград, 2001. - Вып. 4. C. $125-128$.

7. Биргер, И. А. Расчет на прочность деталей машин : справочник / И. А. Биргер, Б. Ф. Шорр, Г. Б. Иосилевич. М. : Машиностроение, 1993. - 640 с.

\title{
О. И. Драчев ${ }^{\text {, А. Н. Кравцов }}{ }^{2}$ \\ ДВУХРЕЗЦОВОЕ ТОЧЕНИЕ ТЕЛ ВРАЩЕНИЯ
}

\author{
${ }^{1}$ Тольяттинский государственный университет, Тольятти, Россия \\ ${ }^{2}$ Научно-производственный кооператив «ОНИКС», Ирбит, Россия \\ E-mail: doi05@mail.ru':npk-oniks@yandex.ru²
}

Рассмотрена технология двухрезцового чернового и чистового точения тел вращения применительно к токарным станкам. Показана динамика формирования рабочих поверхностей детали путем продольных колебаний резцов с фазовым запаздыванием чистового резца относительно чернового. Рассмотрена динамика чистового резца в функции коэффициента демпфирования. Приведена математическая модель процесса двухрезцового точения.

Ключевые слова: технология, точение, качество поверхность, точность, динамическая модель.

\section{O. I. Drachev ${ }^{1}$, A. N. Kravtsov ${ }^{2}$}

\section{TWO CUTTING TURNING OF BODIES OF REVOLUTION \\ ${ }^{1}$ Togliatti State University (Russia) \\ ${ }^{2}$ Research and Production Company "ONIKS", Irbit (Russia)}

The technology of two-cut rough and rough turning of rotation bodies in relation to lathes is considered. Dynamics of part working surfaces formation by longitudinal oscillations of cutters with phase delay of finishing cutter from rough one is shown. Dynamics of finishing cutter in function of damping coefficient is considered. The mathematical model of two-cut turning process is given.

Keywords: technology, turning, surface quality, accuracy, dynamic model.

Точность механической обработки тел вращения зависит от многих факторов, важнейшим из которых является упругая деформация ТОС при статических и динамических воздействиях $[1,2]$. При высоком уровне развития производства одной из основных задач науки становится изыскание резервов для дальнейшего увеличе- ния показателей качества и производительности механической обработки. Одним из этих путей является метод, основанный на обработке осесимметричных деталей двумя резцами [1]. Создание станков повышенной точности не решает задачу обработки тел вращения, так как в этом случае точность и качество обрабатывае-

(С Драчев О. И., Кравцов А. Н., 2021. 
мой поверхности детали определяется динамикой процесса резания. Одним из эффективных методов позволяющих решить задачу, связанную с обработкой тел вращения, является встройка в ТОС двух резцового метода точения. Он основан на работе двух резцов - чернового и чистового последовательно установленных по продольной оси детали, причем чистовой резец колеблется с отставанием по фазе, что позволяет уменьшить шероховатость обрабатываемой поверхности. Введение извне в зону резания колебания резца требует дополнительной энергии и разработки привода с системой управления [2]. В работе предлагается устройство для точения наружных поверхностей тел вращения, содержащее державку с двумя резцами - черновым и чистовым. Черновой и чистовой резцы установлены на два диаметральных размера. Обе державки резца оснащены упругими элементами, а между ними в осевом направлении детали установлены балка с упругим элементом и гидравлический демпфер. Параллельно перемычке установлен гидравлический демпфер, обеспечивающий сдвиг колебаний по фазе чистового резца относительно чернового. Чистовой резец настроен на припуск, равный величине выступов шероховатости от чернового резца с учетом отжима от сил резания в пределах допуска заданного чертежом.

Таким образом, при помощи двухрезцового точения, можно достичь следующих результатов: увеличения надежности работы инструмента за счет стабилизации его высокочастотных колебаний, повышения точности. А также качества обработки путем снижения шероховатости и уменьшения энергоемкости процесса чистового точения за счет использования энергии разрушения металла на черновом точении и высокочастотных колебаний чистового резца равной частоте ламелизации стружки.

Оснащение резцов упругими элементами позволяет колебаться в заданных пределах в функции сил резания и использовать в качестве источника высокочастотных колебаний сам процесс резания. Балка, связывающая два резца и оснащенная упругим элементом, позволяет передать энергию процесса резания и частоту колебаний чистовому резцу. Встроенный демпфер между резцами обеспечивает сдвиг по фазе колебаний чистового резца, что снижает уровень шероховатости при чистовом точении. При такой настройке резцов чистовой резец не копирует винтовую поверхность оставленную черновым резцом, а срезает выступы от чернового резца Н до величины $\mathrm{H}_{1}$. Кроме того чистовой резец снимает малую стружку и усилия резания, следовательно, малы и упругие перемещения чистового резца минимальны, что приводит к повышению точности обработки.

Предлагаемая конструкция резцового блока для двухрезцового точения иллюстрируется следующими рисунками. На рис. 1 представлен общий вид резцового блока, а на рис. 2 схема образования шероховатости на обработанной поверхности. Двухрезцовый блок для токарной обработки осесимметричных деталей показан рис. 1 и закреплен в резцедержателе 8 относительно обрабатываемой детали 9. Профилограммы обработанной поверхности детали от чернового и чистового точения 10 и 11 представлены на рис. 2.

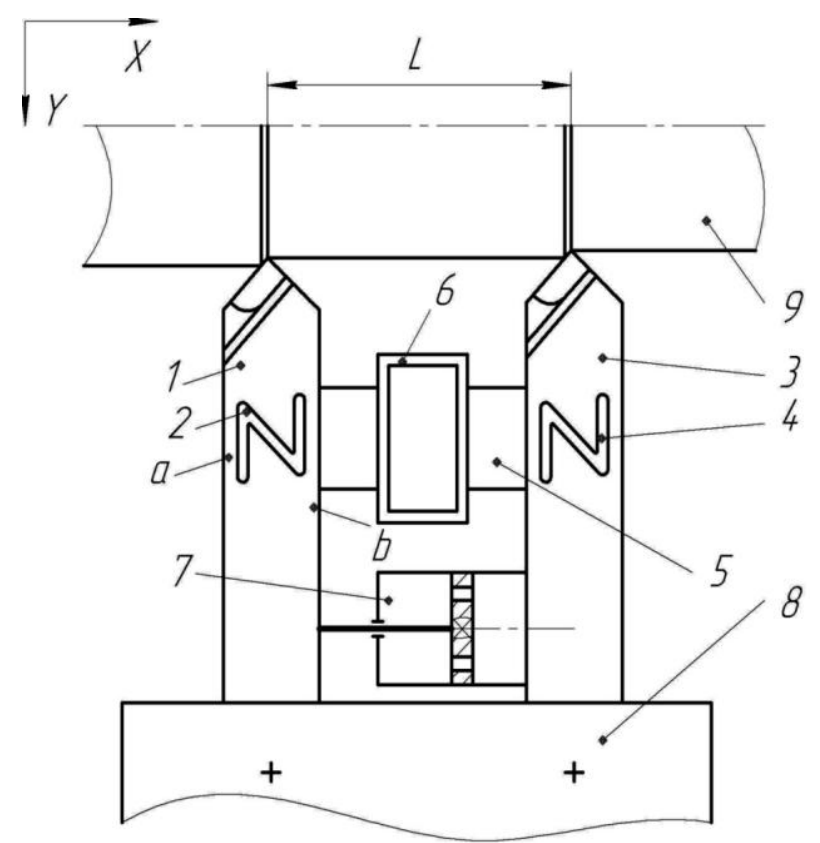

Рис. 1. Общий вид двухрезцового блока:

1 - черновой резец с упругим элементом $2 ; 3$ - чистовой резец, с упругим элементом $4 ; 5$ - балка; 6 - упругий элемент балки;

7 - демпфер; 8 - резцедержатель; 9 - обрабатываемая заготовка

Двухрезцовый блок работает следующим образом. Блок резцов настраивают по эталону образца на заданные диаметры, закрепляют в резцедержателе станка и подводят к обрабатываемой детали. Первым включается в процесс резания черновой резец 1 , а далее через расстояние $L$ начинает работать чистовой резец 3 . В каждый резец встроены упругие элементы 2 и 4 с упругими элементами $a$ и $\sigma$ (см. рис. 1). Резцы соединены балкой 5 с встроенным упругим элементом 6, выполненным в виде прямо- 
угольника, что позволяет обоим резцам колебаться в плоскости YOX в одном направлении. Параллельно балке 5 между резцами 1 и 3 встро- ен демпфер 7 , корпус которого закреплен на державке резца 3, а шток поршень крепится на державке резца 1 .

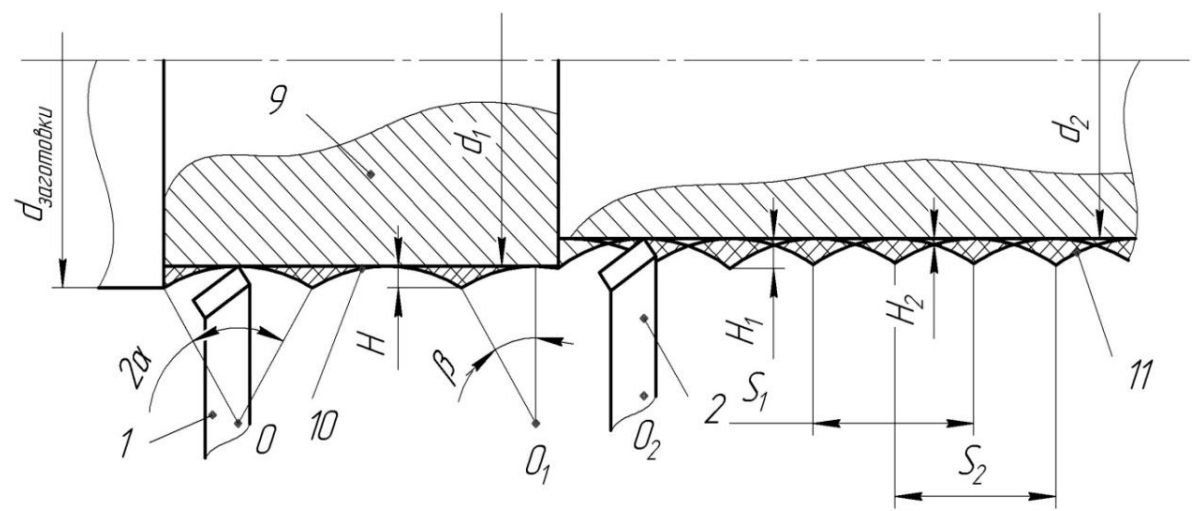

Рис. 2. Схема образования шероховатости на обработанной поверхности

Если чистовой резец 3 отстает по фазе от чернового резца 1 (рис. 2), это происходит за счет работы демпфера 7, то осевое смещение чистового резца 3 относительно вершины чернового резца 1 производится на угол $\beta$ (угол запаздывания), оставляя на обработанной поверхности неровность высотой $\mathrm{H}_{1}$, меньшей $\mathrm{H}$. Такая конструкция двух резцового блока позволяет колебаться чистовому резцу 3 в одном направлении с одинаковыми частотами, с разными фазами.

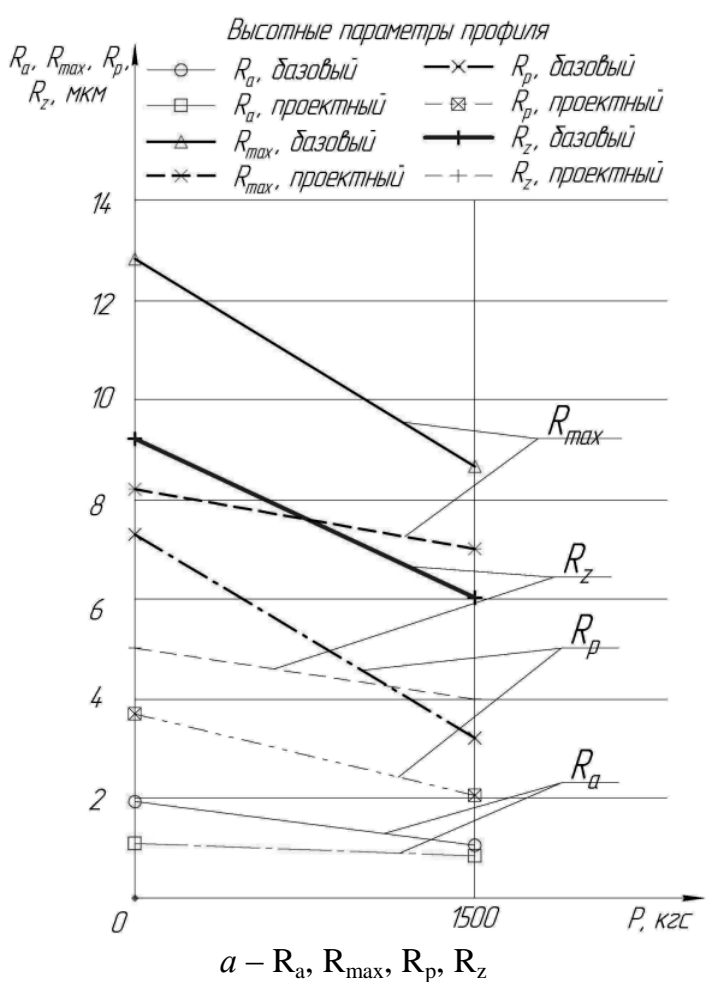

Проверить то, как регулирование жесткости резца отразится на качестве обработанной поверхности, возможно при помощи следующего приближения. А именно - работа чернового резца соответствует чистовой обработке жестким резцом до нагружения образца из стали Ст. 3 (P = 0 кгс). А чистового - нагружению обработанного образца силой $\mathrm{P}=1500$ кгс (внедрение ролика диаметром 16 мм и длиной 12 мм) по воздействию на высотные параметры шероховатости поверхности (рис. 3).

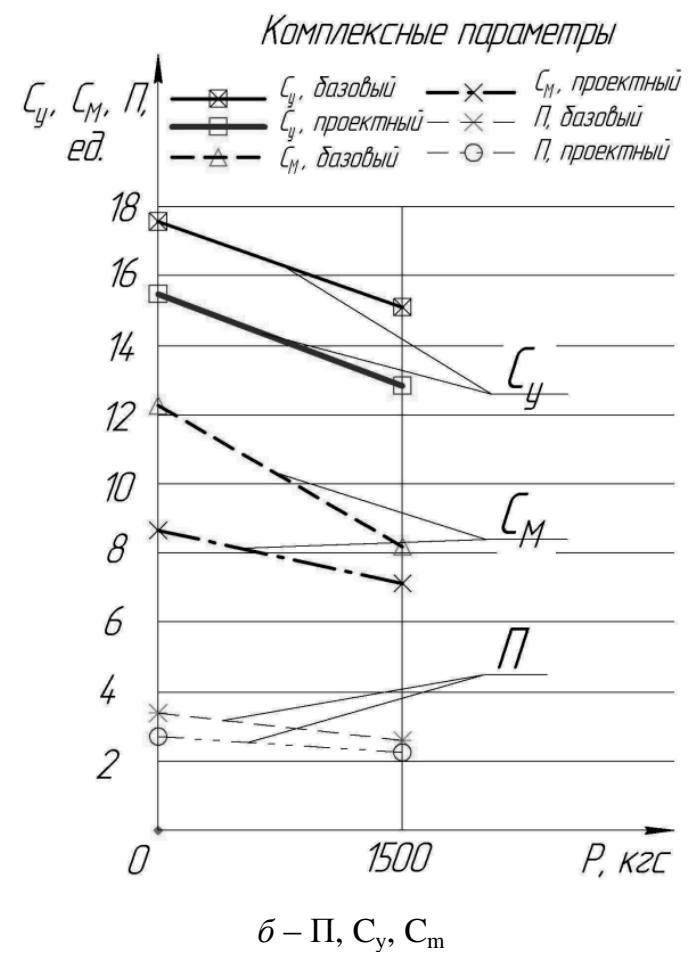

Рис. 3. Параметры обработанной поверхности ( $\mathrm{P}=1500$ кгс, базовый - резец 1 , проектный - резец 2$)$, $\mathrm{H}_{\mathrm{p}}=2.5$ мкм, $\mathrm{W}_{\mathrm{p}}=2.5$ мкм, $\mathrm{K}^{\mid}=1.3$ 
Известно (см. $[1,2])$, что величина высокочастотных колебаний резца оказывает существенное влияние на высотные параметры шероховатости профиля обработанной поверхности (например, $\mathrm{R}_{\mathrm{z}}$ ), а величина параметра $\mathrm{R}_{\mathrm{z}}$ растет пропорционально амплитуде колебаний (хотя, почти не зависит от их частоты). В свою очередь, на шаговые параметры профиля (например, $\mathrm{S}_{\mathrm{m}}$ ) вибрации высокой частоты оказывают намного менее заметное влияние, поэтому в исследовании их не рассматриваем.

Испытания проводились жестким резцом на станке 1525Ф3. Условия, применяемая аппаратура и оборудование описаны в [3]. Для оценки качества поверхности детали применялись высотные параметры шероховатости поверхностного слоя (см. рис. 3). А для эксплуатационных свойств - комплексные параметры состояния поверхностного слоя (см. [3, 4]). Регламентировался параметр профиля обработанной поверхности $-\mathrm{R}_{\mathrm{a}}$, лимитирующими свойствами детали являлись - контактная жесткость (комплекс П), усталостная прочность (комплекс $\mathrm{C}_{\mathrm{y}}$ ) и прочность посадок с натягом (комплекс $\mathrm{C}_{\mathrm{m}}$ ).

Проведенное исследование, показало, что поведение профильных и комплексных параметров $\mathrm{C}_{\mathrm{m}}, \mathrm{C}_{\mathrm{y}}$ и П на обработанной поверхно- сти образцов было следующим (см. рис. 3). А именно, пятна контакта формировались при первых нагружениях, комплексы стабилизировались, достигая равновесных значений, высотные параметры после нагружений уменьшались (для однократного приложения нагрузки усилием $\mathrm{P}=1500$ кгс). Что говорит об улучшении эксплуатационных свойств поверхностного слоя при обработке.

Таким образом, использование конструкции двухрезцового блока позволяет повысить производительность обработки, качество и точность обработанной поверхности, улучшить надежность работы инструмента и обеспечить стабильность форм и размеров в эксплуатационный период работы детали.

\section{БИБЛИОГРАФИЧЕСКИЙ СПИСОК}

1. Драчев, О. И. Технология изготовления маложестких осесимметричных деталей / О. И. Драчев. - Санкт-Петербург : Политехника, 2012. - 289 с., ил.

2. Кумабэ, Д. Вибрационное резание / Д. Кумабэ // Машиностроение, 1985 г. -424 с., ил.

3. Кравцов, A. Н. Обеспечение эксплуатационных свойств поверхностей деталей при изготовлении А. Н. Кравцов, Н. В. Кравцов. - Ирбит : ЗАО «ОНИКС», 2011. - 267 с., ил.

4. Инженерия поверхности деталей / колл. авт. ; под ред. А. Г. Суслова. - М. : Машиностроение, 2008. - 320 с., ил.

\title{
Ж. А. Каргина, Д. В. Крайнев \\ ОРГАНИЗАЦИЯ СМК КАК НАПРАВЛЕНИЕ ПОВЫШЕНИЯ КОНКУРЕНТОСПОСОБНОСТИ ПРЕДПРИЯТИЯ
}

\author{
Волгоградский государственный технический университет \\ E-mail: zhanna.kargina.2015@mail.ru
}

Приводится теоретическое описание СМК, рекомендаций по улучшению, описаны понятия о качестве, подходы к управлению, структура, требования и встречающиеся проблемы совершенствования.

Ключевые слова: система менеджмента качества, подход, контроль качества, совершенствование.

\section{Zh. A. Kargina, D. V. Krainev}

\section{ORGANIZATION OF THE QMS AS A DIRECTION FOR IMPROVING THE COMPETITIVENESS OF THE ENTERPRISE}

\section{Volgograd State Technical University}

The article provides a theoretical description of the QMS, recommendations for improvement, describes the concepts of quality, management approaches, structure, requirements and problems encountered in improving it.

Keywords: quality management system, approach, quality control, improvement.

На современном этапе развития вопросы качества охватывают не только качество продукции и услуг, но и качество самого управле- ния, которое непосредственно отвечает за процесс формирования соответствующего уровня продукции.

(C) Каргина Ж. А., Крайнев Д. В., 2021. 
Следствием этого является получившая широкое распространение система менеджмента качества (далее-СМК), которая, как правило, становится неотъемлемой подсистемой любого производства, охватывая все стадии деятельности предприятия [1].

Постоянное совершенствование СМК и повышение качества выпускаемой продукции является одним из условий поддержания высокой конкурентоспособности предприятия и обеспечения эффективности производства.

В основе внедрения стандартов ИСО серии 9000 в большинстве случаев лежат следующие цели:

- использование стандартов как средство повышения результативности деятельности предприятия, а затем сертификация СМК на соответствие требованиям стандартов. Такой подход является гарантией того, что деятельность по повышению качества работы и ее результатов не будет заменена работой с бумагами;

- внедрение стандартов только с целью сертификации СМК. В таком случае сертификат становится ключом, открывающим доступ на экспортные рынки и конкурентным преимуществом на отечественных. И хотя такой подход и создает условия для реализации основных принципов, на которых базируются стандарты ИСО серии 9000 [2], но рассмотрение СМК как единовременной акции не дает реального результата, а иногда добавляет внутренних конфликтов.

В качестве основной причины неэффективного внедрения СМК выступает подмена реального внедрения СМК получением сертификата - формальное внедрение СМК, недостаточная интеграция процессов менеджмента качества с процессами общего менеджмента предприятия, слабое понимание сущности принципов TQM и их несистемное применение.

Рассмотрим СМК на ООО ТПК «Нижняя Волга». Компания производит и поставляет клиентам климатическое испытательное оборудование [3].

Камеры, выпускаемые предприятием ООО ТПК «Нижняя Волга», позволяют с заданными параметрами точности моделировать агрессивное воздействие окружающей среды, разнообразные климатические явления на испытуемый образец и могут быть применены в научно-исследовательских учреждениях, разрабатывающих оборудование для машиностроения, а также оборонной и авиационной промышленности.

При сравнении ООО ТПК «Нижняя Волга» с конкурентами (представлено на рисунке) видно, что с 2014 по 2019 год наблюдался стабильный рост объема продаж компании ООО ТПК «Нижняя Волга» [4].

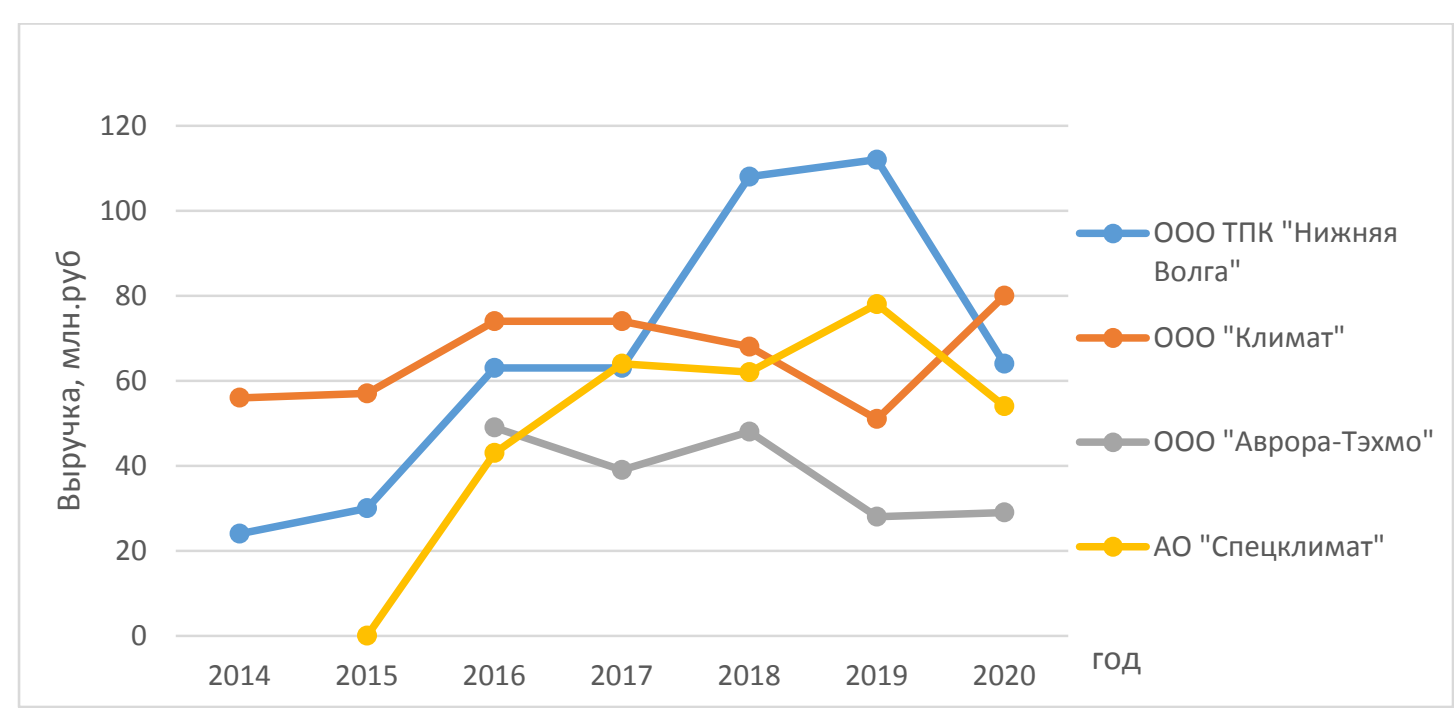

Конкуренты ООО ТПК «Нижняя Волга»

Спад финансовых результатов компании в 2020 году явился результатом пандемии коронавируса COVID-19 и выявил неготовность предприятия реагировать на подобные угрозы, необходимость внутренних изменений и под- хода ко всей системе управления. Данное утверждение подтверждается финансовыми результатами ООО «Климат» за тот же период, а также опубликованными результатами аналитических обзоров. 
Так, по данным информационного агентства РБК [5] успешное функционирование в условиях пандемии COVID-19 потребовало от предприятий значительных изменений, в частности, в таких бизнес-процессах, как управление персоналом, маркетинг, планирование и онлайнпродажи.

В организационной структуре ООО ТПК «Нижняя Волга» каждый отдел на предприятии отвечает за свои функции. Но их цели и задачи взаимосвязаны с функциями других отделов и направлены на благо всей организации.

Стоит отметить, что данная структура управления обладает и целым рядом недостатков, таких как:

- дублирование функций руководителя функциональных специалистов в процессе управленческой деятельности;

- медленное принятие решений;

- нежелание отдельных руководителей брать на себя ответственность за принимаемые решения;

- возникновение внутрипроизводственных барьеров, ограничивающих рамки заинтересованности функциональных подразделений в эффективном развитии производства.

Еще один недостаток функционирования СМК выражается в том, что на предприятии слабо развит уровень автоматизации документооборота. В результате на сотрудников накладывается большой объем бумажной работы, много данных приходится анализировать вручную, отчетность также составляется вручную и хранится преимущественно в бумажном виде.
Эффективность и качество работы отделов и организации в целом - разные. Выходом из этой ситуации может стать введение системы мотивации, опирающейся не только на результаты отдельных отделов, но и предприятия в целом.

В современных условиях работа ООО ТПК «Нижняя Волга» не может быть успешной без постоянного совершенствования деятельности, стратегического планирования, эффективности управления, которые должны быть направлены на улучшение качества выпускаемой продукции. Добиться успеха можно в непрерывном процессе, который требует постоянного совершенствования системы качества. Для такого процесса компания должна иметь определенную стратегию, план действий, который с легкостью можно донести до каждого сотрудника.

\section{БИБЛИОГРАФИЧЕСКИЙ СПИСОК}

1. Астафеев, В. Д. Управление качеством на основе использования международных стандартов ИСО серии 9000 и отечественных стандартов - ГОСТов / В. Д. Астафеев. - Москва : Лаборатория книги, 2012. - 107 с.

2. Адлер, Ю. П. Форум Деминга: стратегия качества для России / Ю. П. Адлер, Д. В. Маслов. - Астрахань : Астраханский государственный университет, Издательский дом «Астраханский университет», 2012. - 256 с.

3. Продукция ООО ТПК «Нижняя Волга» [Электронный ресурс]. - Режим доступа : http://n-volga.ru/klimaticheskie-kamery (Дата обращения: 20.03.2020)

4. Магазин исследований [Электронный ресурс]. Режим доступа : https://marketing.rbc.ru/research/42452/ (Дата обращения 3.04.2021)

5. Исследование влияния пандемии COVID-19 на российский бизнес [Электронный ресурс]. - Режим доступа : https://sapmybiz.rbc.ru/RBK_Issledovanie_vliyaniya_pandemii_ COVID_19_na_rossiyskiy_biznes (Дата обращения 20.05.2021)

\section{В. И. Карлов, Ю. И. Крыхтин \\ К ОЦЕНКЕ И ПРОГНОЗИРОВАНИЮ ТРИБОТЕХНИЧЕСКИХ ПОКАЗАТЕЛЕЙ ПАР ТРЕНИЯ ИЗ СПЕЧЕННОГО ПОРОШКОВОГО ФРИКЦИОННОГО МАТЕРИАЛА С РАЗНЫМИ СТАЛЬНЫМИ КОНТРТЕЛАМИ ДИСКОВОГО ФРИКЦИОННОГО УСТРОЙСТВА*}

\section{Волгоградский государственный технический университет}

E-mail: au@vstu.ru

Приведены аппроксимирующие зависимости триботехнических показателей пар трения из спеченного порошкового фрикционного материала и разных стальных контртел дискового фрикционного устройства от скоростей скольжения, полученные по результатам испытаний на машине трения и предназначенные для выбора материалов пар трения.

Ключевые слова: сухое трение, триботехнические показатели, коэффициент трения, износ, скорости скольжения, температура, аппроксимирующие уравнения, машина трения, спеченный порошковый фрикционный материал, стальное контртело.

(С Карлов В. И., Крыхтин Ю. И., 2021.

* Работа выполнена при поддержке РФФИ и Администрации Волгоградской области по проекту № 19-48-340021. 


\section{I. Karlov, Yu. I. Krykhtin \\ TO ESTIMATE AND PREDICT TRIBOTECHNICAL PARAMETERS OF FRICTION PAIRS FROM SINTERED POWDER FRICTION MATERIAL WITH DIFFERENT STEEL COUNTERFACES FOR DISK FRICTION DEVICE}

\section{Volgograd State Technical University}

Approximating dependencies of tribotechnical parameters of friction pairs sintered powder friction material and different steel counterfaces of disk friction device on sliding speeds, obtained by results of tests on friction machine and intended for selection of materials of friction pairs, are given.

Keywords: dry friction, tribotechnical parameters, friction coefficient, wear, sliding speeds, temperature, approximating equations, friction machine, sintered powder friction material, steel counterface.

В трансмиссиях транспортных машин широко применяются дисковые тормоза (ДТ) [1]. Условия работы остановочного двухдискового тормоза гусеничных машин (ГМ) массой до 18 т характеризуются следующими показателями: удельной работой трения до $900 \mathrm{Hм} / \mathrm{cm}^{2}$; линейной скоростью скольжения относительно контртела до 96 м/с; удельной нагрузкой на поверхности трения до 0,25 МПа; временем буксования при торможении $-4 \ldots 8$ секунд; диапазоном рабочих температур $-60 \ldots+900^{\circ} \mathrm{C}$.

Выбор фрикционных материалов и контртел пар трения и исследования фрикционных устройств с высокими скоростями скольжения и новыми спеченными порошковыми фрикционными материалами представляют значительный интерес [2, 3].

Для обеспечения надежной и долговечной работы конструкции ДТ транспортных ГМ с большой удельной мощностью (свыше 30 л.с./Т) требуется внедрение современных спеченных порошковых фрикционных материалов $[1,2]$. Актуальным является оценка и прогнозирование триботехнических показателей пар трения с новыми спеченными порошковыми фрикционными материалами и соответствующими им контртелами при проектировании новых фрикционных устройств и модернизации существующих. Для этого прежде всего необходимо определить существенные параметры пар трения и режимов их работы, определяющие свойства фрикционных устройств.

Фрикционные свойства устройств характеризуются коэффициентами трения $\mu_{c m}, \mu_{\partial и н}$. Статический момент трения в устройстве (нет проскальзывания) определяется по формуле:

$$
\begin{gathered}
M_{\text {тр.ст. }}=\mu_{\text {ст }} \cdot q \cdot S \cdot R_{\text {ср }} \cdot z \cdot \beta=M_{\text {кр }} \cdot i=716,2 \frac{N}{n} i ; \\
\mu_{\text {ст }}=\text { const. }
\end{gathered}
$$

Динамический момент трения в устройстве (есть проскальзывание) определяется по формуле:

$$
\begin{gathered}
M_{\text {тр.дин. }}=\mu_{\text {дин }} \cdot q \cdot S \cdot R_{\text {ср }} \cdot z \cdot \beta=M_{\text {кр }} \cdot i=716,2 \frac{N}{n} i ; \\
\mu_{\text {дин }}=f\left(v_{\text {ск }}, q, t\right) .
\end{gathered}
$$

где $\mu_{\text {сг }}, \mu_{\text {дин }}-$ коэффициенты трения статический и динамический соответственно, $q-$ удельная нагрузка; $S$ - площадь поверхности трения; $R_{\text {ср }}-$ средний радиус трения, $z$ - число пар трения; $\beta$ - коэффициент запаса фрикционного устройство; $M_{\text {кр }}-$ крутящий момент ДВС, (кГс м $) ; v_{\text {ск }}-$ скорость скольжения; $t$ температура; $N$ - мощность ДВС, $n$ - обороты ДВС; $i-$ передаточное отношение от ДВС к фракционному устройству. Удельная мощность трения равна $N_{\text {уд }}=q \cdot v_{\text {ск }}$.

Эксплуатационные свойства устройств характеризуются темпом износа пары трения $\delta=f\left(v_{\text {ск }}, q, t\right)$ и изменением физико-механических свойств материалов, а также их геометрии (коробление).

При разработке и исследовании необходимо учитывать существенное изменение $\mu_{\text {дин }}, \delta, t$ от скорости скольжения $v_{\text {ск }}$ и удельной нагрузки $q$ для обеспечения надежной и долговечной конструкции.

Целью работы является оценка и прогнозирование триботехнических показателей пар сухого трения: спеченный порошковый фрикционный материал - разные стальные контртела для дискового фрикционного устройства трансмиссии транспортной легкой ГМ массой до 18 т с большой удельной мощностью.

Новизной работы является использование аппроксимирующих уравнений, полученных по результатам триботехнических испытаний на машине трения спеченного порошкового фрикционного материала сухого трения, работающего с разными стальными контртелами, для оценки и прогнозирования триботехнических 
показателей пар трения дискового фрикционного устройства.

В исследовательской работе используются результаты триботехнических испытаний спеченного порошкового фрикционного материала на $\mathrm{Fe}$ - основе CMK-I37 на машине трения [3]. Материалами контртел служат стали 40X, $38 \mathrm{XC}$, сталь 35Л с требуемой термической обработкой, применяемые в реальных узлах. В процессе эксперимента фиксируются и рассчитываются следующие триботехнические показатели: время приработки трибосопряжения; линейный износ подвижного сочленения в период приработки; сила (коэффициент $\mu_{\text {дин }}$ ) трения установившегося износа; темп износа пары трения $\delta$ подвижного сочленения в период установившегося износа; предельное давление схватывания пары трения, температура.

На каждую точку приходится не менее 3...5 испытываемых образцов, а средняя величина определяемого параметра (X) рассчитывается по формуле: $X=\left(X_{1}+X_{2}+\ldots+X_{n}\right) / n$, где $X_{1}, X_{2}$, $\ldots, X_{\mathrm{n}}$ - результаты измерений; $\mathrm{n}$ - число измерений.

Для проведения лабораторных испытаний используется машина трения МТ-68, схема которой представлена на рис. 1 [1].

На машине трения исследованы зависимости коэффициента трения $\mu_{\text {дин }}$, температуры $t$, темпа износа $\delta$ пар трения от скорости скольжения $v_{\text {ск }}$ и удельной нагрузки $q$.

Триботехнические лабораторные испытания проводились на машине трения МТ-68 в режиме непрерывного нагружения при постоянной скорости скольжения $v_{\text {ск }}=5 ; 10 ; 20 ; 25 ; 30 \mathrm{M} / \mathrm{c}$ и неизменным давлением нагружения $q=0,5$; 1,$5 ; 2,5$ МПа в установившийся период. Резуль-

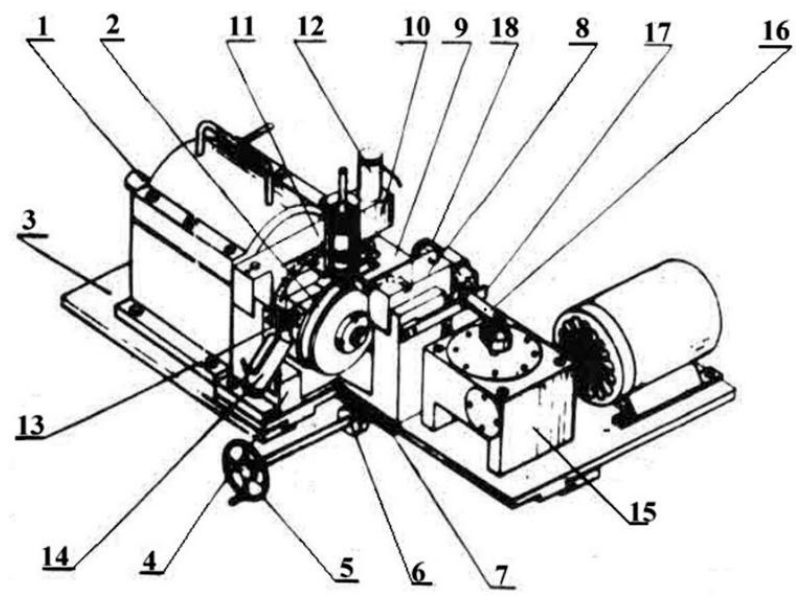

Рис. 1. Схема узла трения машины МТ-68:

1 - вал; 2 - контртело; 3 - суппорт; 4 - узел трения; 5 - маховик; 6 - шестерня; 7 - рейка; 8 - направляющие; 9 - качающаяся каретка; 10 - нагружающее устройство; 11 - цанговый зажим; 12 - индуктивный датчик замера суммарного износа; 13 - пружина; 14 - индуктивный датчик замера суммарной силы трения; 15 - червячный редуктор; 16 - кривошипный механизм; 17 - пружина; 18 - индуктивный датчик замера силы трения от возвратнопоступательного движения

таты лабораторных триботехнических испытаний (без подачи смазки в зону контакта всухую) на машине МТ-68 пар трения: спеченный порошковый фрикционный материал СМК-І37 с контртелами: сталь 40Х, 38XC (255...302 НВ;1,25 Ra), сталь 35Л ( $q=1,5 \mathrm{MПа}$ для всех контртел) представлены точками на рис. 2, 3, 4. Здесь же приведены графики аппроксимирующих зависимостей исследуемых триботехнических показателей от $v_{\text {ск }}$ и $q$. При этом стали $40 \mathrm{X}$ и $38 \mathrm{XC}$ - это материал нажимных дисков остановочного ДТ, а сталь 35 Л это материал корпусных деталей ДТ, который вводится взамен чугунных корпусных деталей из-за появления на них трещин при штатных испытаниях на дизельном инерционном стенде.

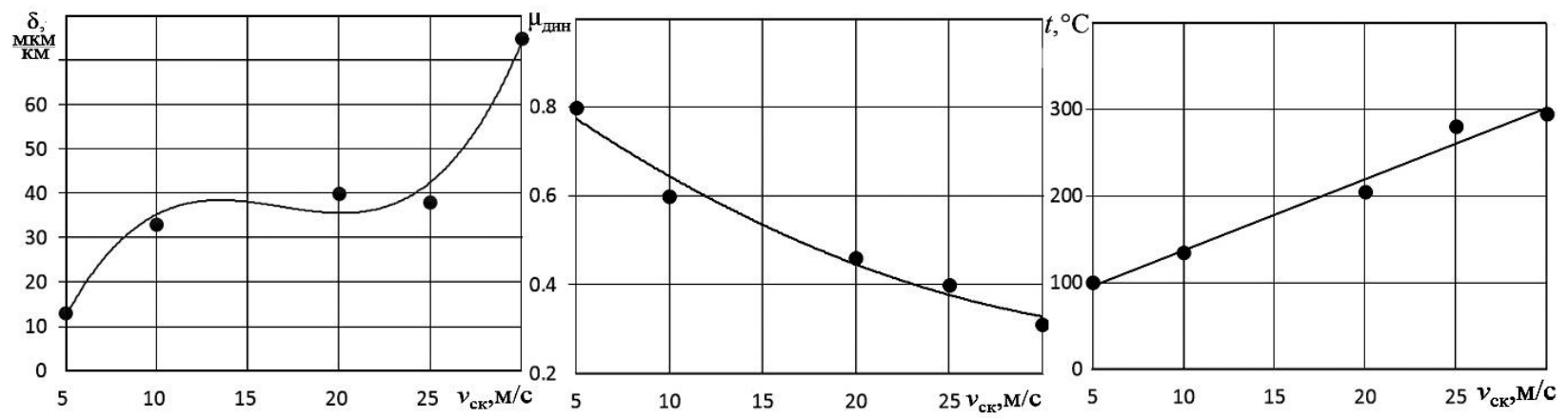

Рис. 2. Результаты исследования пары трения СМК-I37 - сталь 40X [4] 

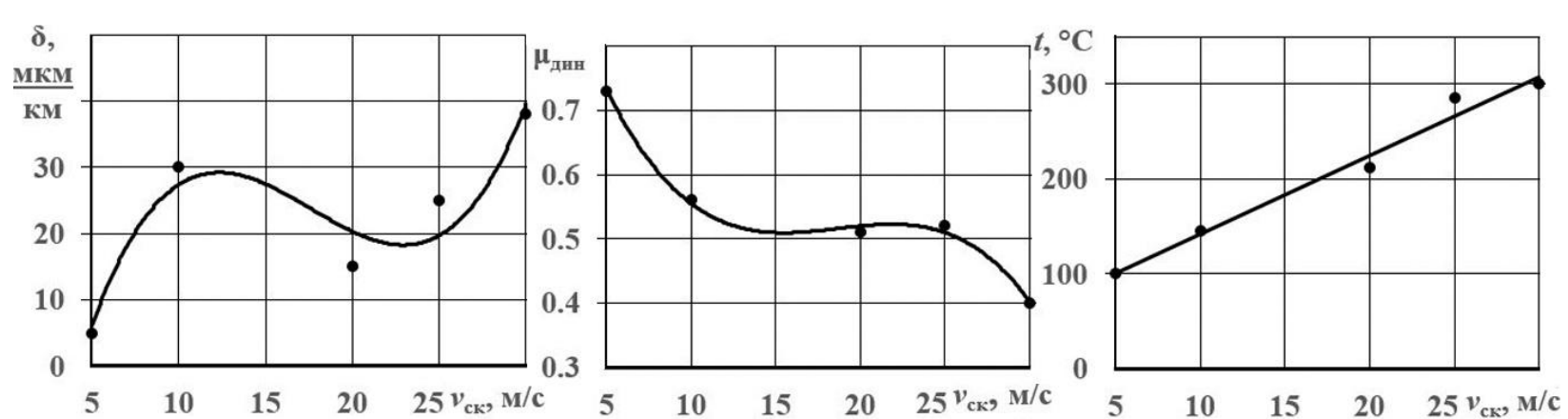

Рис. 3. Результаты исследования пары трения СМК-І37 - сталь 38XC
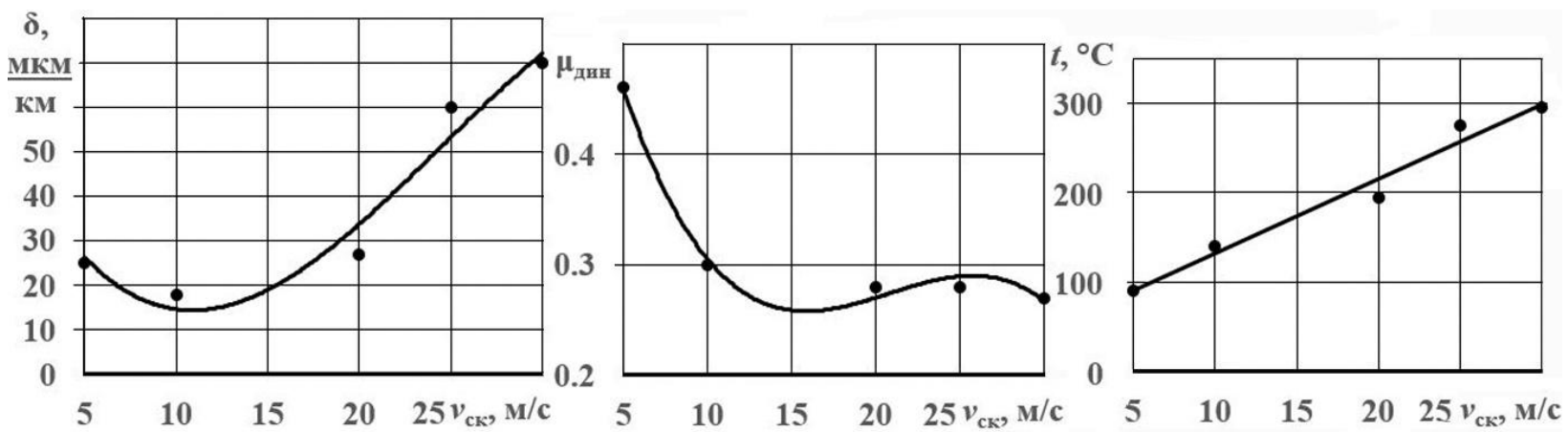

Рис. 4. Результаты исследования пары трения СMK-I37 - сталь 35Л

Уравнения аппроксимирующих кривых пар трения СМК 137-разные стальные контртела

\begin{tabular}{|c|c|}
\hline Пара трения & Для скорости скольжения $v_{\text {ск }}=5 \ldots 30 \mathrm{M} / \mathrm{c}$ и $q=1,5 \mathrm{MПа}$ \\
\hline $\begin{array}{l}\text { СМК } 137 \\
\text { сталь } 40 \mathrm{X}\end{array}$ & $\begin{array}{l}\delta, \text { мКм } / \text { км }=0,0198 \bar{v}_{\text {ск }}^{3}-0,9992 \bar{v}_{\text {ск }}^{2}+16,146 \bar{v}_{\text {ск }}-46,118 ; \mathrm{R}^{2}=0,9765 ; \\
\mu_{\text {дин }}=0,0004 \bar{v}_{\text {ск }}^{2}-0,0321 \bar{v}_{\text {ск }}+0,925 ; \mathrm{R}^{2}=0,9747 ; \\
t,{ }^{\circ} \mathrm{C}=8,2093 \bar{v}_{\text {ск }}+55,233 ; \mathrm{R}^{2}=0,978\end{array}$ \\
\hline $\begin{array}{l}\text { СМК-I37 - } \\
\text { сталь } 38 \mathrm{XC}\end{array}$ & $\begin{array}{l}\delta, \text { МКм } / \text { Км }=0.0185 \bar{v}_{\text {ск }}^{3}-0.9788 \bar{v}_{\text {ск }}^{2}+15.702 \bar{v}_{\text {ск }}-50.294 ; \mathrm{R}^{2}=0.8997 ; \\
\mu_{\text {дин }}=-0.0001 \bar{v}_{\text {ск }}^{3}+0.0057 \bar{v}_{\text {ск }}^{2}-0.1029 \bar{v}_{\text {ск }}+1.1171 ; \mathrm{R}^{2}=0.9958 ; \\
t,{ }^{\circ} \mathrm{C}=8.2767 \bar{v}_{\text {ск }}+59.419 ; \mathrm{R}^{2}=0.9806\end{array}$ \\
\hline $\begin{array}{l}\text { СМК-I37 - } \\
\text { сталь 35Л }\end{array}$ & $\begin{array}{l}\delta, \text { МКм } / \text { км }=-0.0075 \bar{v}_{\text {ск }}^{3}+0.5455 \bar{v}_{\text {ск }}^{2}-9.2123 \bar{v}_{\text {ск }}+59.706 ; \mathrm{R}^{2}=0.9506 ; \\
\mu_{\text {дин }}=-7 \mathrm{E}-05 \bar{v}_{\text {ск }}^{3}+0.0041 \bar{v}_{\text {ск }}^{2}-0.081 \bar{v}_{\text {ск }}+0.7682 ; \mathrm{R}^{2}=0.9913 ; \\
t,{ }^{\circ} \mathrm{C}=8.2907 \bar{v}_{\text {ск }}+49.767 ; \mathrm{R}^{2}=0.9732\end{array}$ \\
\hline
\end{tabular}

$\bar{v}_{\text {ск }}-$ безразмерная величина $v_{\text {ск }}$, м c; $R^{2}$ - достоверность аппроксимации.

Анализ полученных результатов позволяет в зависимости от условий работы фрикционного устройства (скорости скольжения $v_{\text {ск }}$ и удельной нагрузки $q$ ) прогнозировать и выбирать необходимые триботехнические показатели: коэффициент трения, удельную мощность трения, износостойкость и температуру по аппроксимирующим уравнениям для конкретной пары трения при проведении необходимых расчетов и исследованиях.
Из анализа полученных зависимостей видно, что пары трения СМК 137-сталь 40Х, СМКI37 - сталь 38XC, CMK-I37 - сталь 35Л имеют приемлемые триботехнические показатели для использования в тяжелонагруженных ДТ [5].

\section{Заключение}

Результаты исследования позволяют делать оценку и прогнозирование триботехнических показателей пары трения - темпа износа $\delta$, коэффициента трения $\mu_{\text {дин }}$, температуры $t$ пары 
трения в зависимости от скорости скольжения $v_{\text {ск }}$ и удельной нагрузки $q$ дискового фрикционного устройства по аппроксимирующим уравнениям процесса трения, полученных с использованием результатов триботехнических испытаний на машине трения МТ-68. Аналогичные результаты могут быть получены для пар трения с различными сочетаниями фрикционных материалов и контртел.

Работа может быть использована для оценки и предварительного выбора триботехнических показателей пар трения, спеченных порошковых фрикционных материалов на $\mathrm{Fe}$ - основе и разных стальных контртел при создании надежных и долговечных фрикционных устройств трансмиссий легких транспортных ГМ с большой удельной мощностью.

\section{БИБЛИОГРАФИЧЕСКИЙ СПИСОК}

1. Трансмиссии гусеничных и колесных машин / В. М. Труханов, В. Ф. Зубков, Ю. И. Крыхтин, В. Ф. Желтобрюхов. - М. : Машиностроение, 2001. - 736 с.

2. Шаповалов, В. В. Актуальные задачи современной триботехники и пути их решения / В. В. Шаповалов, А. Сладковски, А. Ч. Эркенов // Известия высших учебных заведений. Машиностроение. - 2015, № 1 (658), 64-75.

3. Федорченко, И. М. Современные фрикционные материалы / И. М. Федорченко, В. М. Крячек, И. И. Панаиоти. - Киев : Наукова думка. - 1975.

4. Крыхтин, Ю. И. Спеченные материалы на $\mathrm{Fe}$ основе для фрикционных устройств большой удельной мощности / Ю. И. Крыхтин, В. И. Карлов // Трение и износ Гомель ИММС НАН Беларуси. - 2020. - Том 41, № 2. C. $180-187$.

5. Крыхтин, Ю. И. Разработка дисковых остановочных тормозов с металлокерамическими дисками в трансмиссиях ГМ и математической модели нагружения фрикционного материала / Ю. И. Крыхтин, В. И. Карлов // Сборка в машиностроении и приборостроении. - 2019, № 1, 13-17.

УДК 621.9

DOI: $10.35211 / 1990-5297-2021-8-255-30-34$

\title{
О. А. Макарова, А. А. Жданов, Р. И. Аржуханов, Е. О. Сиукова \\ ОПРЕДЕЛЕНИЕ ОПТИМАЛЬНОГО ЗАДНЕГО УГЛА ПИЛЫ ПАКЕТНОЙ РЕЗКИ С ИСПОЛЬЗОВАНИЕМ МОДЕЛИРОВАНИЯ ТЕПЛОВЫХ ПОЛЕЙ
}

\author{
Волгоградский государственный технический университет \\ E-mail: olgamakarova5024@gmail.com
}

В настоящей публикации рассматривается вопрос, связанный с исследованием распределения тепла в зубе пилы с модифицированной геометрией с учетом периодичности процесса резания холодного металлопроката дисковыми пилами.

Ключевые слова: дисковые пилы, пакет труб, пакетная резка, температурное поле.

\section{O. A. Makarova, A. A. Zhdanov, R. I. Arzhukhanov, E. O. Siukova \\ DETERMINING THE OPTIMAL BACK ANGLE OF A BATCH SAW USING THERMAL FIELD MODELING}

\section{Volgograd State Technical University}

This publication deals with the issue related to the study of the heat distribution in the tooth of a saw with a modified geometry, taking into account the frequency of the process of cutting cold rolled metal with circular saws.

Keywords: circular saws, pipe package, batch cutting, temperature field.

В данной работе исследовалось распределение тепловых потоков в зубе пилы с измененным задним углом при резании холодного металлопроката дисковыми пилами в ТПЦ - 2 АО «ВТЗ» г. Волжский.

Пакетная резка салазковой пилой холодного металлопроката характеризуется высокой производительностью. Она нашла широкое применение в производственных условиях металлургических предприятий всей страны. В тоже время большой износ инструмента требует анализа тепловых процессов $[1,2]$.
Значительное увеличение температуры зуба пилы обусловлено выделением большого количества тепла вследствие трения задней поверхности инструмента об обрабатываемый материал. Это приводит к деформации зубьев пилы и интенсивному износу. Нагрев зубьев стандартных дисковых пил был рассмотрен в работе [2].

При введении заднего угла $\alpha$ изменяется геометрия режущей части инструмента и уменьшается длина контакта. Это приводит к уменьшению тепловыделения и увеличению стойкости инструмента. Анализ температурно- 
го поля для зуба пилы с модифицированной геометрией проводится с использованием метода источников теплоты, включая отраженные источники теплоты [3].
В работе был проведен сравнительный анализ пилы с традиционным зубом и пилы с новой геометрией. Рассмотрим распределение тепловых полей на одном зубе пилы.

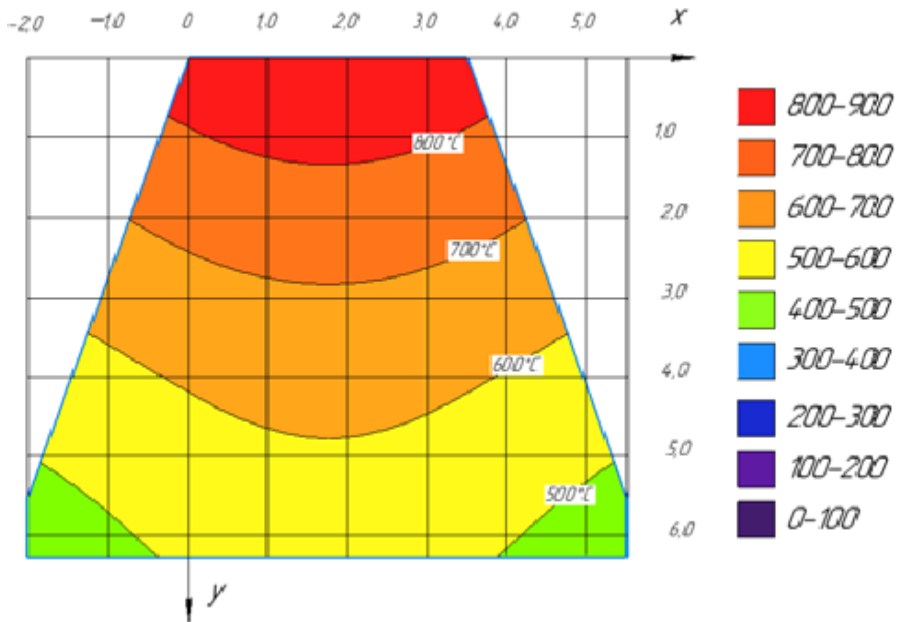

Рис. 1. Температурное поле зуба пилы с традиционной геометрией $\left(\alpha=0^{\circ}\right)$

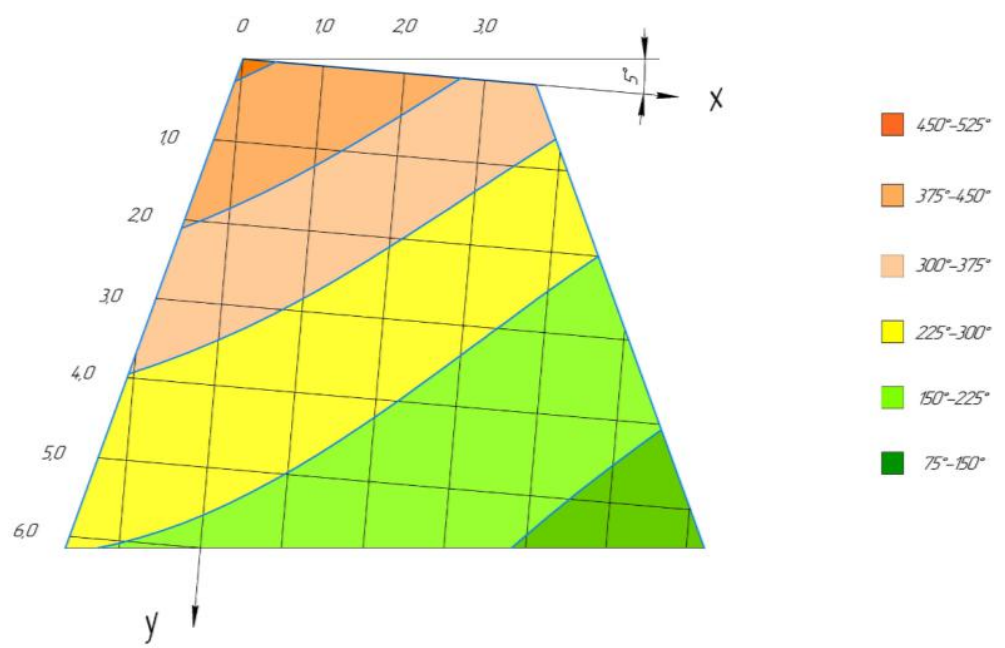

Рис. 2. Температурное поле зуба пилы с традиционной геометрией $\left(\alpha=5^{\circ}\right)$

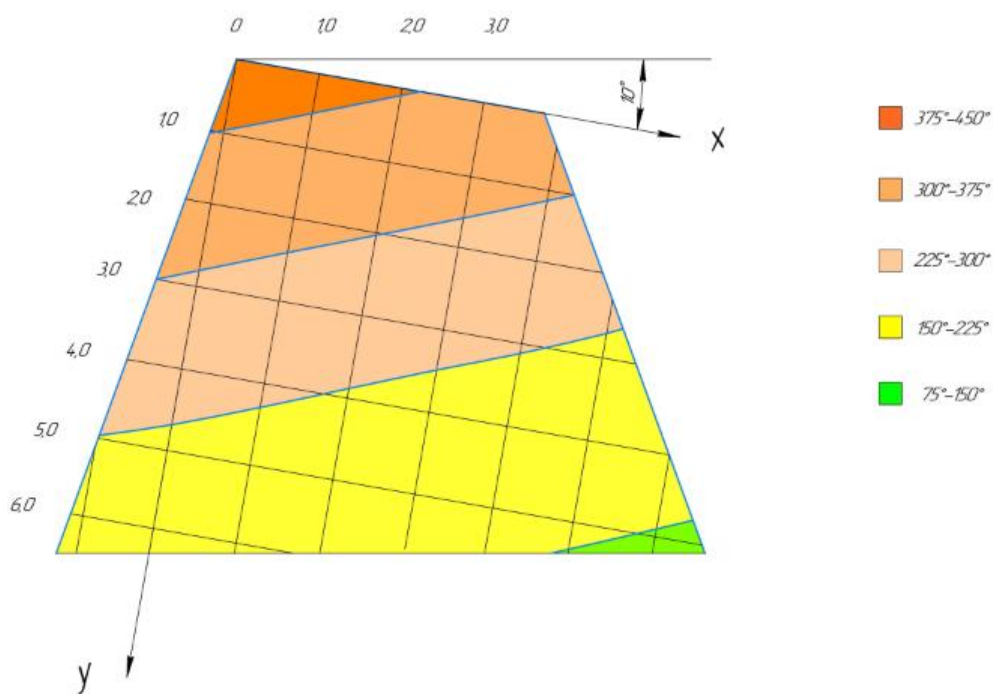

Рис. 3. Температурное поле зуба пилы с традиционной геометрией $\left(\alpha=10^{\circ}\right)$ 


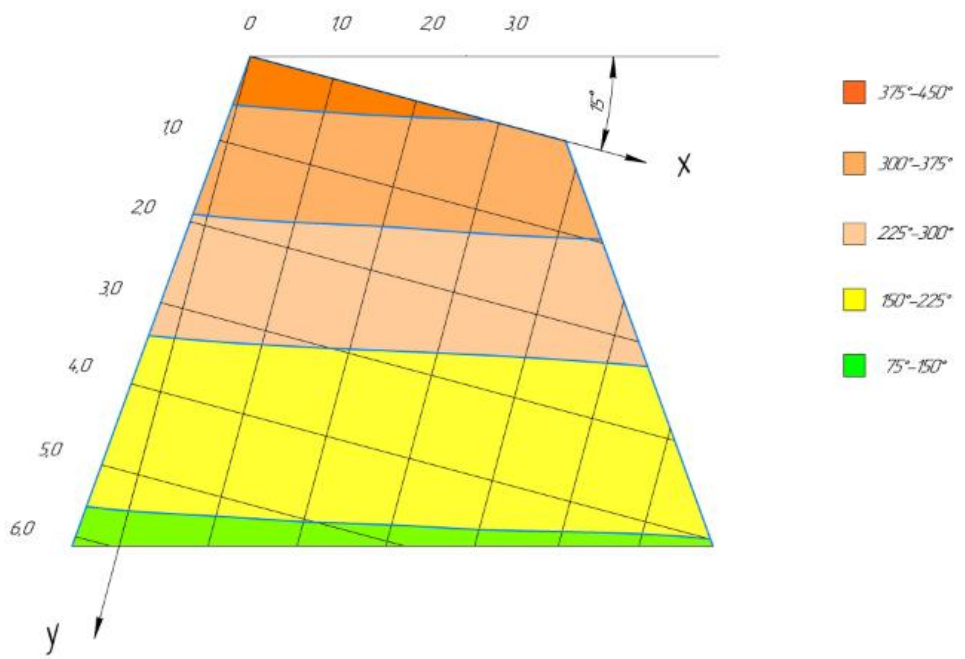

Рис. 4. Температурное поле зуба пилы с традиционной геометрией $\left(\alpha=15^{\circ}\right)$

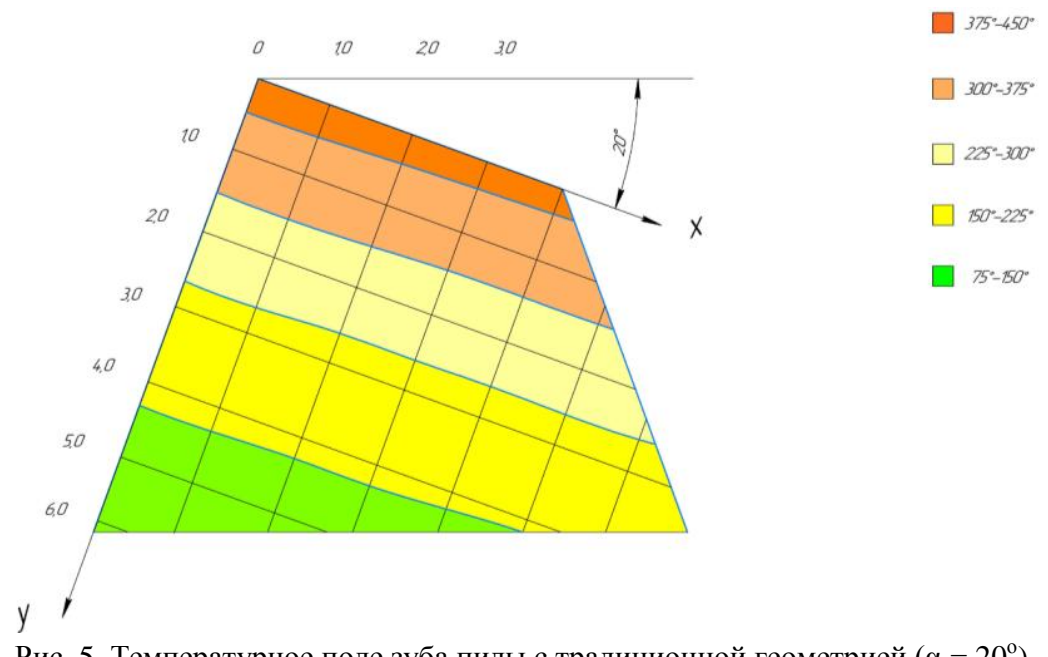

При резке пилой с традиционной формой зубьев (рис. 1), вершина зуба подвергается высоким температурам нагрева, что вызывает значительную ее деформацию. Пятно контакта по задней поверхности увеличивается, что обуславливает еще больший нагрев и катастрофический износ зуба.

Рассматривая пилу с модифицированной геометрией (рис. 2-5), можно сделать вывод об изменении направления тепловых потоков. Самым нагретым участком зуба является его вершина.

Проводя сравнительный анализ влияния заднего угла $\alpha$ на распределение тепловых потоков, можно сделать заключение о том, что оптимальным является интервал заднего угла равный 10-15 градусов. При этой величине $\alpha$, температура в зоне резания становится идемпотентной (сохраняется ее значение при увеличении заднего угла). О чем можно судить по графику зависимости температуры от величины $\alpha$ (рис. 6). Увеличение заднего угла больше 15 градусов приведет к ослаблению тела зуба пилы, что приведет к уменьшению стойкости.

Для пилы, работающей при небольших подачах и с высокими температурами, одним из основных показателей является стойкость пилы в резах. Проведя эксперименты, было определено, максимальное количество резов на пиле пакетной резки. По результатам исследования была получена зависимость стойкости пилы от вида обрабатываемого материала. В качестве материала заготовки были рассмотрены стали 08X13, 12X13, 20Х13, Сталь 20, а пилы сталь 50ХГФА (рис. 7). 


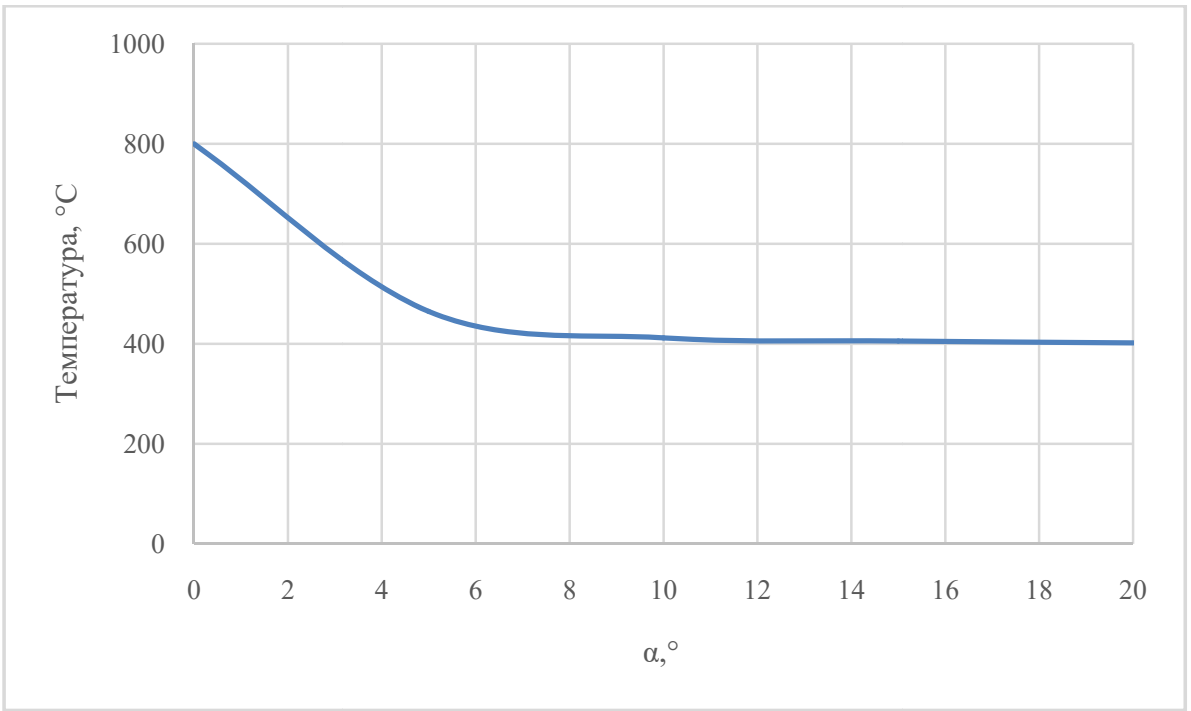

Рис. 6. График зависимости температуры от величины заднего угла $\alpha$

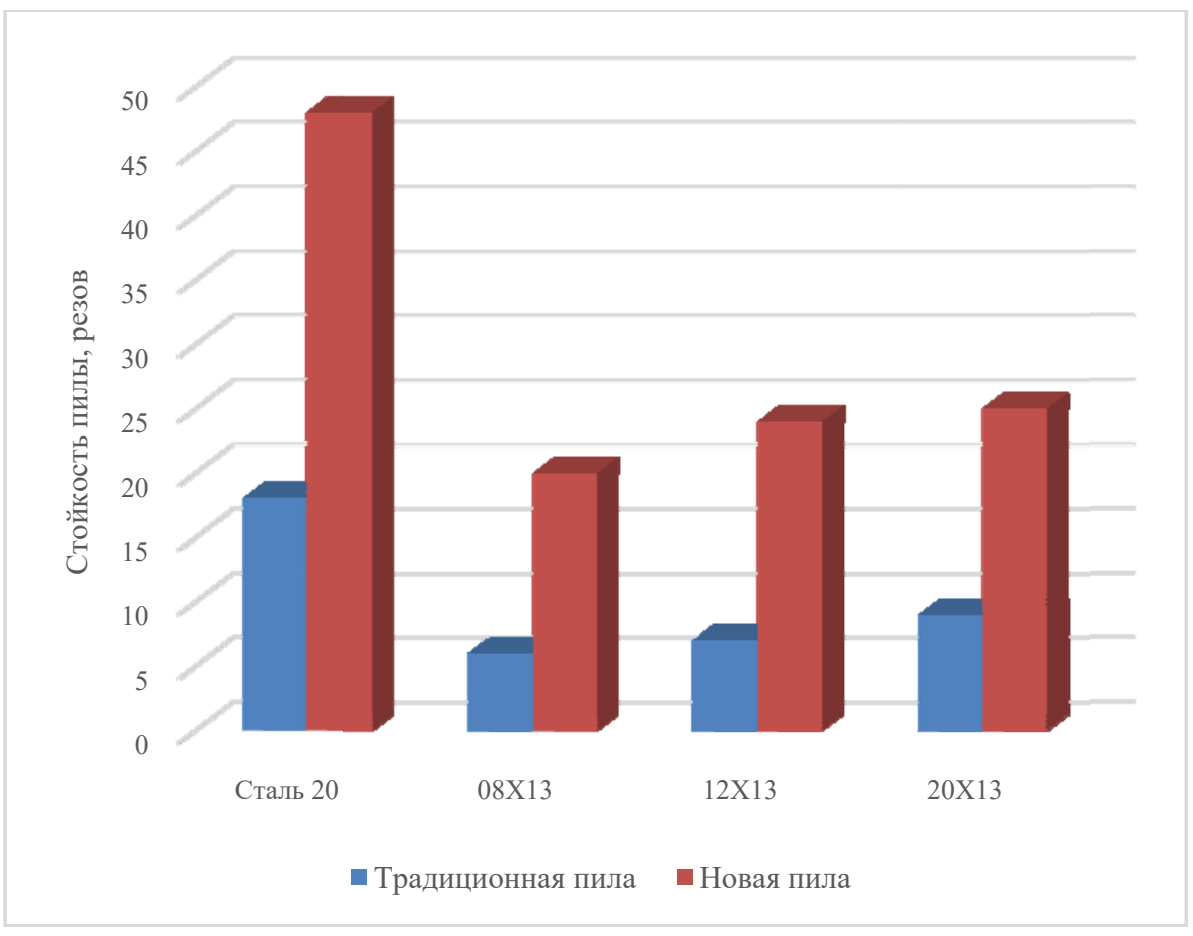

Рис. 7. Зависимость стойкости пилы от обрабатываемого материала (задний угол для модифицированной пилы $\alpha=15^{\circ}$ )

После проведения экспериментальной части, на основе теоретических расчетов можно сделать следующий вывод:

1. Пила с модифицированным зубом, достигает максимальной стойкости при значении заднего угла $\alpha=15^{\circ}$, количество резов при обработке Сталь 20, достигло 48 резов, что вдвое больше, чем у пилы с традиционной формой зуба.

2. Стойкость хромистых сталей (08X13, 12Х13, 20X13) намного ниже углеродистой стали (Сталь 20), вследствие пониженной теплопровод- ности и повышенной вязкости. По результатам эксперимента она составила $15-25$ резов.

\section{БИБЛИОГРАФИЧЕСКИЙ СПИСОК}

1. Thermofrictional pipe cutting / Ю. Н. Полянчиков, А. И. Курченко, А. И. Банников, О. А. Макарова, А. А. Банников // Russian Engineering Research. - 2010. - Vol. 30, № 7. - С. 745-746.

2. Исследование распределения тепла в зубе пилы с учетом периодичности процесса при пакетной резке холодного металлопроката / А. И. Банников, О. А. Макарова, И. С. Ширяев, А. Д. Осипов // Известия ВолгГТУ : научный журнал № 8 (243) / ВолгГТУ. - Волгоград, 2020. - 
(Серия «Прогрессивные технологии в машиностроении»). C. 7-13.

3. Резников, A. Н. Теплофизика процессов механической обработки материалов / А. Н. Резников. - М. : Машиностроение, 1981. -279 с.
4. Теория сварочных процессов / А. В. Коновалов [и др.]. - М. : Изд-во МГТУ им. Н. Э. Бау-мана. - 2007.

5. Чиркин, B. C. Теплофизические свойства материалов / В. С. Чиркин. - Рипол Классик, 2013.

УДК 621.923

DOI: $10.35211 / 1990-5297-2021-8-255-34-37$

\section{В. А. Носенко, В. Е. Пузырькова, Н. Д. Сердюков, Д. С. Слепцов \\ ВЛИЯНИЕ СРЕДЫ НА ПОКАЗАТЕЛИ ПРОЦЕССА ШЛИФОВАНИЯ СТАЛЕЙ И ТИТАНОВЫХ СПЛАВОВ ИНСТРУМЕНТОМ ИЗ КОРУНДА И КАРБИДА КРЕМНИЯ}

\section{Волжский политехнический институт (филиал) ВолгГТУ}

E-mail: vladim.nosenko2014@yandex.ru

При шлифовании титановых сплавов кругом из карбида кремния СОЖ обеспечивает бесприжоговое шлифование, снижение показателей процесса шлифования. Существенное влияние СОЖ оказывает на отношение одноименных составляющих силы резания на встречном и попутном проходах стола при шлифовании сталей корундовым кругом и титановых сплавов кругом из карбида кремния.

Ключевые слова: шлифование, стали, титановые сплавы, корунд, карбид кремния, СОЖ, показатели процесса.

\section{A. Nosenko, V. E. Puzyrkova, N. D. Serdyukov, D. S. Sleptsov \\ THE INFLUENCE OF THE MEDIUM ON THE INDICATORS OF THE GRINDING OF STEELS AND TITANIUM ALLOYS WITH A TOOL FROM CORUNDUM AND SILICON CARBIDE}

\section{Volzhsky Polytechnic Institute (branch) of VSTU}

When grinding titanium alloys with a silicon carbide wheel, the coolant provides cut-free grinding, a decrease in the performance of the grinding process. The coolant has a significant effect on the ratio of the same components of the cutting force on the counter and passing passes of the table when grinding steels with a corundum wheel and titanium alloys with a silicon carbide wheel.

Keywords: Grinding, steels, titanium alloys, corundum, silicon carbide, coolant, process indicators.

Шлифование относится к финишным процессам обработки, поэтому к качеству обработанной поверхности предъявляют особые требования. Например, недопустимым является наличие шлифовочных прижогов и трещин, растягивающих напряжений и пр. Образование данных дефектов связано с повышением контактной температуры в зоне резания [1].

Одной из причин увеличения температуры в зоне резания является адгезионная активность обрабатываемого материала, что в наибольшей степени проявляется в процессе шлифования титановых сплавов. Несмотря на то, что стали на основе железа относят к наименее адгезионно активным металлам, их шлифование также сопровождается адгезионными процессами $[2,3]$.

Одним из наиболее эффективных методов снижения адгезионной активности и температуры резания, является применение смазочно-охлаждающих технических сред, образующих в зоне контакта абразив-металл защитные пленки смазки $[4,5]$. При шлифовании титановых сплавов наибольшее влияние на показатели процесса оказывает СОЖ с присадкой калия фосфорнокислого трехзамещенного [6, 7]. В ряде случаев возникает необходимость совместного шлифования сталей и титановых сплавов.

Цель работы: исследовать влияние титановой СОЖ в присадкой калия фосфорнокислого трехзамещенного на показатели процесса шлифования сталей и сплавов на основе титана.

\section{Методика исследования}

Испытания проведены на плоскошлифовальном станке модели 3711 методом врезного шлифования. Режим обработки: $v-37 \mathrm{~m} / \mathrm{c}, v_{\mathrm{s}}-$ $12 \mathrm{~m} / \mathrm{мин,}, S_{\mathrm{t}}-0,01 \mathrm{mм} / 2 \mathrm{x}, T-0,5$ мм. В качестве обрабатываемых металлов использовали стали марок Сталь 10832, Сталь 40Х и титановые сплавы марок ВТ3-1, ВТ22. Длина обрабатыва-

(C) Носенко В. А., Пузырькова В. Е., Сердюков Н. Д., Слепцов Д. С., 2021. 
емой поверхности 100 мм, ширина 10 мм. Исследования проведены без использования СОЖ (всухую) и с охлаждением специальной СОЖ для шлифования титановых сплавов, содержащей в качестве основной присадки калий фосфорнокислый трехзамещенный. Расход СОЖ 9 л/мин. Характеристики шлифовальных кругов: 24AF60M7B, 54CF60M7B.

\section{Результаты исследований}

При шлифовании корундовым кругом без использования СОЖ шероховатость обработанной поверхности сталей 10832 и 40Х различается незначимо (рисунок, $a$ ). Коэффициент шлифования стали 40Х по сравнению с 10832 снижается на $14 \%$ (рисунок, б).

Согласно принятой методике исследований радиальная подача шлифовального круга осуществляется на двойной ход стола. Перед контактом с заготовкой на каждом встречном движении стола (рабочий ход) шлифовальный круг опускается на 10 мкм. В результате упругих деформаций в системе станка происходит отжим в паре заготовка-инструмент. В связи с этим, снижается глубина

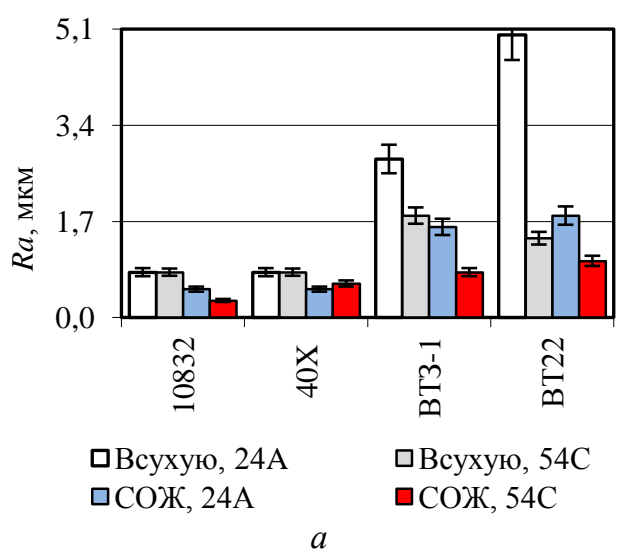

шлифования и объем удаляемого металла. Оставшаяся часть металла удаляется на обратном попутном движении стола (холостой ход). Обратный ход стола происходит без подачи круга, поэтому его можно рассматривать, как чистовой проход.

О соотношении фактических глубин шлифования на рабочем ходе стола, выполняемом с подачей абразивного инструмента, и холостом ходе можно судить по отношению $\mathrm{Pzl} /$ $P z 2$. (рисунок, в). При шлифовании сталей без СОЖ отношение $P z 1 / P z 2$ изменяется в диапазоне 2,3-2,4. Это означает, что горизонтальная составляющая силы резания на попутном движении стола без подачи круга в 2,3-2,4 раза меньше, чем на встречном движении стола с радиальной подачей круга. В данном случае вполне обосновано движение стола на обратном проходе без подачи можно рассматривать, как чистовой проход. Значимого различия отношение Pzl / Pz2 на сталях 10832 и 40X не имеет. Поэтому данный фактор не будет оказывать существенного влияния на шероховатость обработанной поверхности.

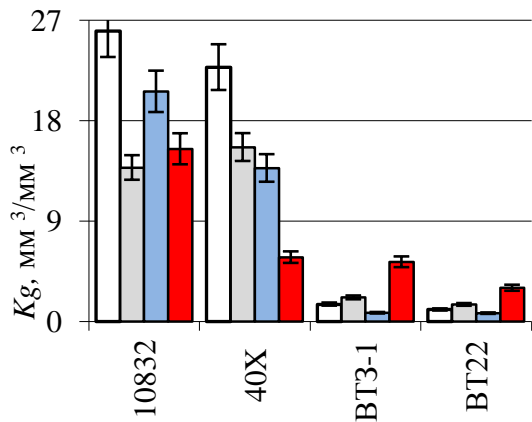

口Всухую, 24А $\square$ Всухую, 54C $\square$ СОЖ, $24 \mathrm{~A} \quad \square \mathrm{CO}, 54 \mathrm{C}$

6

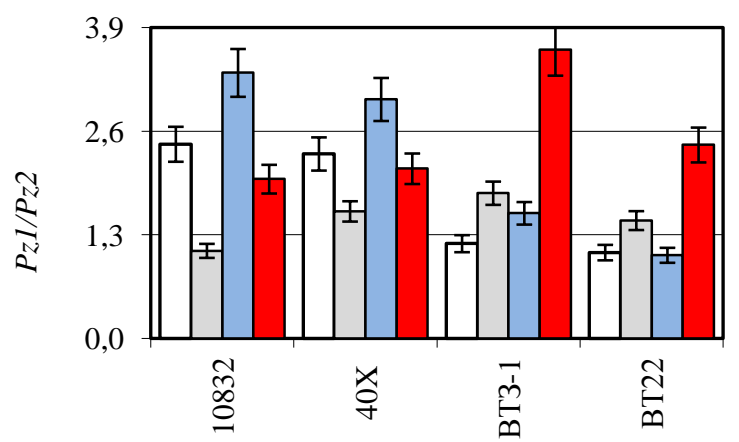

口Всухую, 24A 口СОЖ, 24A

$\square$ Всухую, $54 \mathrm{C}$

$\square \mathrm{CO}, 54 \mathrm{C}$ 
Изменение коэффициента шлифования на $14 \%$ также не оказывает ощутимого влияния на шероховатость обработанной поверхности. Поэтому при шлифовании сталей 10832 и 40X получены одинаковые значения параметра $R a$ (см. рисунок, $a$ ).

С использованием СОЖ, по сравнению со шлифованием всухую, $R a$ на сталях снижается в 1,6 раза с 0,8 до 0,5 мкм. Коэффициент шлифования также снижается: на стали 10832 в 1,3 раза, на $40 \mathrm{X}$ - в 1,7 раза.

С использованием охлаждения отношение сил возрастает до 3,3. Поэтому, несмотря на снижение $K g$, при шлифовании с использованием СОЖ благодаря очевидному снижению температуры в зоне резания и интенсивности адгезионного взаимодействия, уменьшению фактической глубины шлифования на чистовом проходе без радиальной подачи происходит снижение шероховатости обработанной поверхности.

Отношение сил на встречной и попутной подачах при шлифовании титановых сплавов корундовым кругом $P z 1 / P z 2=1,1-1,2$.

При шлифовании сплавов ВТ3-1 и ВТ22 корундовым кругом с использованием СОЖ шероховатость обработанной поверхности по сравнению со шлифованием всухую снижается, соответственно, в 1,7 и 2,8 раз. Коэффициент шлифования также снижается, соответственно, в 1,9 и 1,6 раз. Тем не менее, на обработанной поверхности также образуются прижоги, хотя и в меньшей степени, чем при шлифовании всухую.

Одной из возможных причин снижения $K g$ корундовым кругом с переходом от шлифования всухую к использованию СОЖ может быть эффект термоудара [8].

СОЖ оказывает существенное влияние на интенсивность адгезионного взаимодействия карбида кремния с титановым сплавом [4]. Тем не менее, при шлифовании инструментом из корунда эффективность от действия СОЖ не в состоянии конкурировать с влиянием высокой интенсивности физико-химического взаимодействия корунда с титановым сплавом.

По сравнению с корундовым инструментом коэффициент шлифования всухую сталей кругом из карбида кремния в 2 раза меньше. Шероховатость обработанной поверхности при шлифовании кругом из карбида кремния и корунда одинакова. Отношение сил $P z 1 / P z 2$ при шлифовании кругом из карбида кремния сталей 10832 и $40 \mathrm{X}$ в 2,2 и 1,5 раз меньше. Например, при шлифовании стали 10832 кругом из карбида кремния $P z 1 / P z 2=1,1$, то есть составляющая $P z 2$ на обратном проходе без радиальной подачи всего на $10 \%$ меньше, чем на проходе с подачей 0,01 мм. При шлифовании корундовым кругом без СОЖ отношение $P z 1 / P z 2=2,4$.

При обработке без СОЖ титановых сплавов кругом из карбида кремния $K g$ сплава ВТ22 в 1,7 раза меньше по сравнению со сплавом ВT3-1. Коэффициент шлифования сплава ВТ3-1 по сравнению со сталями 10832 и $40 \mathrm{X}$ снизился, соответственно, в 6,6 и 9,2 раз, сплава ВТ22 в 7,4 и 10,4 раз. С переходом от шлифования всухую к использованию СОЖ $K g$ сплава ВТ3-1 увеличился в 2,5 раза, сплава ВТ22 - в 2,0 раза. Таким образом, только при шлифовании титановых сплава переход от шлифования всухую к обработке с использованием специальной «титановой» СОЖ обеспечивает повышение коэффициента шлифования. При шлифовании более труднообрабатываемого титанового сплава ВТ22 коэффициент шлифования возрастает в меньшей степени, чем на сплаве ВТ3-1.

Шероховатость обработанной поверхности сплава ВТ3-1 почти на 30 \% больше, чем сплава ВT22. С переходом от шлифования всухую к использованию СОЖ $R a$ на сплавах ВТ3-1 и ВТ22 снижается, соответственно, в 2,2 и 1,4 раз.

\section{Выводы}

При шлифовании с радиальной подачей на двойной ход стола введен показатель: отношение составляющей силы резания при движении стола с радиальной подачей шлифовального круга к одноименной составляющей силы резания на обратном движении стола без подачи, позволяющий сделать сравнительную оценку фактической глубины резания на данных движениях стола станка.

При шлифовании сталей и титановых сплавов корундовым кругом переход от шлифования всухую к охлаждению специальной «титановой» СОЖ сопровождается снижением коэффициента шлифования и шероховатости обработанной поверхности.

Многократное увеличение коэффициента шлифования с использованием «титановой» СОЖ происходит при обработке титановых сплавов на основе титана кругом из карбида кремния. Из титановых сплавов ВТ3-1 и ВТ22 наибольшее влияние СОЖ оказывает на показатели процесса шлифования менее труднообрабатываемого сплава ВТ3-1. 


\section{БИБЛИОГРАФИЧЕСКИЙ СПИСОК}

1. Manoj, K. S. Application of eco-friendly nanofluids during grinding of Inconel 718 through small quantity lubrication / K. S. Manoj, R. Madarkar, S. Ghosh, P. V. Rao // Journal of Cleaner Production. 2017. Vol. 141. PP. 1359-1375.

2. Quing, M. Comparative investigation on wear behavior of brown alumina and microcrystalline alumina abrasive wheels during creep feed grinding of different nickel-based superalloys / M. Quing, D. Wenfeng, G. Yulong, X. Jiuhua // Wear. 2019. Vol. 426. PP. 1624-1634.

3. Chaudhari, A. Surface integrity characterization of austenitic, martensitic and ferritic stainless steel under different grinding process / A. Chaudhari, A. S. Awale, A. K. Chakrabarti // Materials Research Express. - 2019. - Vol. 6 (11).

4. Носенко, В. А. Шлифование адгезионно-активных металлов / В. А. Носенко. - М. : Машиностроение, 2000. - 262 с.
5. Носенко, С. В. Влияние СОТС и твердости круга на коэффициент шлифования и шероховатость поверхности при обработке титанового сплава / С. В. Носенко, В. А. Носенко, Л. Л. Кременецкий, Н. Д. Сердюков // Международный научно-исследовательский журнал. 2015. № 12. С. 156-161.

6. Носенко, В. А. Выбор характеристики абразивного инструмента и СОЖ для глубинного шлифования / В. А. Носенко, Н. Ф. Егоров, М. П. Волков // Вестник машиностроения. - 1989. - № 5. - С. 17-21.

7. Носенко, В. А. Технология шлифования : монография / В. А. Носенко, С. В. Носенко; ВПИ (филиал) ГОУВПО ВолгГТУ. - Волгоград: ИУНЛ ВолгГТУ. - 2011. $425 \mathrm{c}$.

8. Носенко, В. А. Роль охлаждающих свойств среды в изнашивании абразива / В. А. Носенко, Г. И. Саютин // Абразивы. - 1975. - № 3. - С. 5-6.

\section{А. Л. Плотников, Ж. С. Тихонова, А. А. Жданов}

\section{МЕТОДЫ ОЦЕНКИ ТЕПЛОФИЗИЧЕСКИХ СВОЙСТВ КОНТАКТНОЙ ПАРЫ «ИНСТРУМЕНТ - СТАЛЬНАЯ ЗАГОТОВКА» И ВОЗМОЖНОСТЬ ИХ ИСПОЛЬЗОВАНИЯ ПРИ РАСЧЕТЕ ПАРАМЕТРОВ ПРОЦЕССА ТОКАРНОЙ ОБРАБОТКИ}

Волгоградский государственный технический университет

E-mail: tikhonovazhs@gmail.com

Проведен анализ методов оценки свойств контактных пар «твердосплавный инструмент - стальная заготовка» с целью использования их для повышения надежности выбора режимов токарной обработки в поколениях систем ЧПУ, оснащенных техническим интеллектом. Скорректированы модели расчета скорости резания, составляющих силы резания, величины шероховатости $R a$ путем введением в их структуру дополнительной информативной величины о свойствах каждой контактной пары - термоЭДС пробного прохода.

Ключевые слова: точность расчета, свойства контактных пар, пробный проход, термоЭДС, надежность процесса резания.

\section{A. L. Plotnikov, Zh. S. Tikhonova, A. A. Zhdanov}

\section{METHODS FOR ESTIMATING THERMFISICAL PROPERTIES \\ OF THE "TOOL - STEEL WORKPIECE" CONTACT PAIR AND THE POSSIBILITY OF THEIR USE IN CALCULATION OF THE PARAMETERS OF THE TURNING PROCESS}

\section{Volgograd State Technical University}

The analysis of methods for assessing the properties of contact pairs "hard alloy tool - steel workpiece" with the aim of improving the reliability of the choice of turning modes in generations of CNC systems equipped with technical intelligence. The models for calculating the cutting speed, the cutting force, the value of roughness Ra, have been corrected by introducing into their structure an additional informative value about the properties of each contact pair - the thermoEMF of the trial cut.

Keywords: calculation accuracy, properties of contact pairs, trial cut, thermoEMF, reliability of the cutting process.

\section{Введение}

В технической литературе, касающейся методик расчета базовых параметров процесса резания при обработке сталей твердосплавным инструментом, таких как скорость резания, составляющие силы резания, показатели качества и точности обработки указывается, что приня- тые методики не обладают достаточной точностью расчета и не обеспечивают высокой надежности протекания процесса резания. Ошибки, допускаемые при расчете, порой достигают 50-150 \% [1, 2, 3]. Это отрицательно сказывается на производительности процесса резания, приводит к большим потерям времени работы 
станка с ЧПУ из-за вынужденной остановки его для неплановой замены инструмента, поиску оператором методом проб и ошибок рациональных условий обработки для выполнения требований, заложенных в технологическом процессе.

Большинство авторов невысокую надежность выбранных режимов связывают с тем, что существующие методики расчета не адекватно отражают взаимосвязанные явления, происходящие в контактной зоне на расчетные величины параметров процесса резания. Они не учитывают вероятностный характер образования контактных пар из всего допустимого диапазона разброса свойств инструмента и стальных заготовок, используя в расчетах среднестатистические (постоянные) значения поправочных коэффициентов и всевозможных констант. В. К. Старков в работе [2] в целях обеспечения выбора надежных режимов обработки выдвигает концепцию, что такие режимы резания могут быть получены только на основе предварительной информации о свойствах каждого резца и каждой стальной заготовки, т. е. на основе оценки свойств каждой контактной пары. Иными словами, В. К. Старков предлагает отказаться от использования понятия «средняя температура по больнице» при лечении больных и пользоваться индивидуальной информацией о температуре каждого больного. Авторы статьи привели этот, в гротесковой форме пример, для описания ситуации с выбором надежных значений параметров процесса металлообработки, когда имеем дело с неизбежным, но допустимым по техническим условиям изготовления, диапазоне разброса режущих свойств инструмента $( \pm 50 \%)$ [4] и разбросе физикомеханических свойств обрабатываемых сталей (около $\pm 10 \%$ [5]. Эта неизбежность связана с особенностями металлургического производства, продуктом которого являются твердые сплавы и обрабатываемые стали и с закономерностями образования твердых металлических растворов на основе углерода.

Предложенная В. К. Старковым [2] принципиально новая методика расчета параметров процесса металлообработки с привлечением оперативной информации о свойствах каждой, случайно собранной контактной пары основывается на возможности получения такой информации. Располагает ли на сегодняшний день теория и практика металлообработки такими способами неразрушающего контроля свойств контактных пар, на сколько реально их использование в станочной практике?

Чтобы ответить на эти вопросы проведем анализ методов оценки теплофизических свойств контактной пары «инструмент - стальная заготовка» и возможность их использования при расчете параметров процесса токарной обработки. Оставим вне обзора способы раздельного контроля свойств инструментального материала и свойств обрабатываемых сталей. При несомненной полезности, такой предварительный раздельный контроль не обеспечивает высокий уровень надежности определения параметров процесса резания. Предпочтительнее использовать предварительную или текущую информацию о свойствах каждой контактной пары и на этой основе рассчитывать (корректировать) режимы обработки.

Первое, что надо отметить - промышленно разработанных способов оценки свойств контактных пар «твердосплавный инструмент стальная заготовка» в практике металлообработки нет. В технической литературе есть описание экспериментальных лабораторных установок на базе токарных станков, где проводились исследования по разработке таких способов (методов) на основе использования сопутствующих процессу резания акустических (виброакустических) и термоэлектрических эффектов.

В работе В. Н. Подураева, А. А. Базарова, А. В. Сибальченко [6] описан метод активного контроля износа инструмента при механической обработке с использованием сигнала акустической эмиссии. В работе В. Л. Заковоротного, И. В. Ладника [7] описана работа системы диагностики состояния процесса обработки на основе виброакустического сигнала из зоны резания. В этих и подобных работах используется информация об акустических (виброакустических) свойствах конкретной контактной пары резецзаготовка с целью прогнозирования износа инструмента и поднастройки режима резания. Следует заметить, что описанные способы получения информации о свойствах контактных пар требуют создания специализированной акустической станции и надежных методик расшифровки сигналов. В этом плане использование термоэлектрического эффекта естественной термопары наиболее доступно и не требует применения дорогостоящего оборудования.

Ю. М. Соломенцев [8], С. В. Васильев [9], использовали величину термоЭДС естествен- 
ной термопары для качественной (лучше - хуже) оценки режущих способностей твердосплавных инструментов. В. В. Трусовым [10] разработана система диагностики состояния инструмента по контактной температуре резания с учетом изменяющихся свойств контактных пар. С. Ф. Корндорф, Е. Е. Мельник [11], использовали термоэлектрический эффект естественной термопары для контроля и диагностики состояния режущего твердосплавного инструмента. В указанных выше работах использовалась косвенная оперативная информация о свойствах сменных контактных пар, что обеспечивало повышенную надежность систем управления (контроля) процессом резания. Использование количественных величин акустического сигнала или сигнала термоЭДС для коррекции математических моделей расчета параметров процесса металлообработки рассмотренные выше способы не предусматривали.

\section{Основная часть}

Впервые количественная величина термоЭДС естественной термопары, измеренная в условиях кратковременного (4-5 секунд) предварительного пробного прохода была использована для коррекции принятой модели расчета скорости резания и описана в работе [12]. Величина термоЭДС была введена в структуру расчетной модели как дополнительная информация о свойствах контактных пар. Скорректированная формула расчета скорости резания для условий получистового точения конструкционных и низколегированных сталей твердосплавными резцами выглядит следующим образом:

$$
V=\frac{A-k E}{T^{0,2} \cdot s^{0,35} \cdot t^{0,15}} \text { (м/мин). }
$$

Отличие формулы (1) от рекомендованной справочно-нормативной литературой [13] состоит в том, что постоянное значение скоростного безразмерного коэффициента $C_{V}$ представлено как функция от термоЭДС пробного прохода, переменная величина которой зависит от физико-механических свойств контактной пары и описывается уравнением прямой:

$$
C_{V}=A-k E,
$$

где $A$ - постоянная, определенная из условий стойкостных испытаний, $A=378 ; k=16,2-$ угловой коэффициент, $E$ - термоЭДС пробного прохода, $T, s, t$ - соответственно стойкость, подача, глубина резания в формуле (1). Формула (1) была проверена на обеспечение задаваемой стойкости $T$ в диапазоне 15-60 минут, при из- менении подачи $s$ от 0,2 до 0,5 мм/об, изменении глубины резания $t$ от 1 до 3 мм при наружном продольном точении сталей марок $45,40 \mathrm{X}$, 20ХН3А, У7, 18ХГТ, 25ХГТ, ШХ15. резцами марок Т15К6, Т14К8, Т5К10.

Для всех проверенных пар «твердосплавный инструмент - обрабатываемые стали» максимальная ошибка по определению действительной стойкости не превышала $15 \%$, что может быть принято как приемлимый уровень точности расчета по сравнению с ошибками расчета по существующими методиками (50-150\%).

Пробный проход с измерением величины термоЭДС на строго фиксированных, одинаковых для всех контактных пар режимах токарной обработки $(V=100 \mathrm{~m} /$ мин; $S=0,1 \mathrm{mм} /$ об; $t=1$ мм) это своеобразный тестовый прием. Он позволяет оценить физико-механические свойства случайно собранных на станке сменных контактных пар за счет всегда сопутствующего термоэлектрического эффекта естественной термопары. При этом, величина термоЭДС пробного прохода используется не как информация о температуре резания, а как косвенный показатель свойств контактных пар, составленных из твердосплавного инструмента и обрабатываемой стальной заготовки. Физической основой способа оценки свойств контактных пар является способность контактной составляющей удельной термоЭДС нести информацию о разности работ выхода электронов из стали и твердого сплава [14]. Работа выхода, в свою очередь, чувствительна к объемным изменениям в сплавах при изменении состава, структуры и образования новых фаз [15]. Различная величина термоЭДС пробного прохода отражает изменение физико-механических свойств каждой новой контактной пары.

Еще одна отличительная особенность скорректированной формулы расчета скорости резания (1) по сравнению с существующими проявляется в том, что она позволяет решать, как прямую задачу выбора надежного значения скорости резания, так и обратную. Т. е. по выбранной скорости резания, принятым величинам подачи и глубины резания и величине термо- э.Д.с пробного прохода можно определять (прогнозировать) время надежной работы резца по зависимости:

$$
T=\left(\frac{A-k E}{V \cdot s^{0,35} \cdot t^{0,15}}\right)^{5} \text { (мин). }
$$

Такой прогноз о времени работоспособности резца всегда необходим оператору-станочнику при корректировке режимов реза 
Методика получения и использования предварительной информации о свойствах контактных пар с целью повышения точности расчета была проверена при расчете составляющих силы резания. Их точное значение необходимо при расчете стрелы прогиба деталей типа «вал» с целью обеспечения точности обработки, расчете зажимных усилий автоматизированного зажимного патрона и т. п. Формула расчета составляющих силы резания $P_{x}, P_{y}, P_{z}$ взятая из источника [13] выглядит следующим образом:

$$
P_{z, y, x}=10 \cdot C_{p} \cdot t^{x_{p}} \cdot S^{y_{p}} \cdot V^{n_{p}} \cdot K_{p}(\mathrm{H}),
$$

где $C_{p}, x_{p}, y_{p}, n_{p}$ - коэффициент и показатели степени при глубине резания, подаче и скорости резания; $K_{p}$ - поправочный коэффициент, представленный как произведение поправок на механические свойства стали и поправок на геометрию инструмента.

Следует подчеркнуть и такую особенность существующих методик определения составляющих силы резания, как отсутствие поправочного коэффициента, учитывающего марку твердого сплава. То есть в существующих методиках принято условие, что, обрабатывая определенную марку стали инструментами из твердосплавных материалов разных марок (при прочих равных условиях) мы получим одинаковую силу резания. Однако практика опровергает эти положения. О влиянии марки твердосплавного инструмента на уровень контактных нагрузок на режущее лезвие отмечено во многих работах и указано на причину: различная теплопроводность, определяющая длину полного контакта стружки и в, конечном итоге, нагрузку на режущее лезвие. Неадекватность расчетной модели приводит к значительным ошибкам расчета, достигающим $100 \%$ и более. Особенно это проявляется при расчете горизонтальных составляющих силы резания.

В скорректированных зависимостях по определению составляющих силы резания при обработке углеродистых и конструкционных сталей, коэффициенты $C_{P z}, C_{P y}, C_{P x}$, учитывающие условия резания и свойства контактируемых пар приняты не постоянными, как в справочной литературе, а выражены как переменные от термо-э.д.с. пробного прохода и определены уравнениями: $C_{P_{z}}=\left(A_{z}+k_{z} \cdot E\right) ; C_{P y}=\left(k_{y} \cdot E+A_{y}\right) ; C_{P x}=\left(k_{x} \cdot E+A_{x}\right)$. Введение в модели расчета составляющих силы резания величины термо-э.д.с. пробного прохода повышает точность их определения в условиях существующего разброса физико-механических и теплофизических свойств со стороны твердого сплава и обрабатываемых сталей. Скорректированные математические зависимости по определению составляющих силы резания выглядят следующим образом [16]:

$$
\begin{aligned}
& P_{z}=\left(A_{z}+K_{z} \cdot E\right) \cdot t^{1} \cdot S^{0,75} \cdot V^{-0,15}, \\
& P_{y}=\left(A_{y}+K_{y} \cdot E\right) \cdot t^{0,9} \cdot S^{0,6} \cdot V^{-0,3}, \\
& P_{x}=\left(A_{x}+K_{x} \cdot E\right) \cdot t^{1} \cdot S^{0,5} \cdot V^{-0,4},
\end{aligned}
$$

где $A_{z}, A_{y}, A_{x}$ - постоянные, соответственно равные $320 ; 300 ; 360$, определенные из условий предварительной обработки; $K_{z}, K_{y}, K_{x}$ - коэффициенты, соответственно равные 5,$5 ; 10 ; 7$.

Использование в скорректированных зависимостях по определению составляющих силы резания значения термоЭДС пробного прохода твердосплавным инструментом по стали, повышает точность определения, т. к. термоЭДС используется как оперативная информация о физико-механических (теплофизических) свойствах контактируемых пар. Точность расчета составляющих силы резания проверялась при обработке заготовок из сталей марок 20, У8А и 45 в условиях получистового точения инструментами марок Т30К4, Т15К6, Т5К10 и ТН20. Погрешность определения составляющих силы резания по скорректированным моделям не превышает $15 \%$.

Применимость принципиально новой методики была испытана при расчете параметра шероховатости $R_{a}$, значение которого закладывается в технологический процесс механической обработки на стадии проектирования. При этом задаваемая величина $R_{a}$ в условиях получистового и чистового точения углеродистых и конструкционных сталей рассчитывается с учетом влияния скорости резания $V$, подачи $S$, переднего угла резца $\gamma$ и радиуса при вершине резца $r$ по зависимости [13]:

$$
R_{a}=K_{0} \frac{S^{K_{1}}(90+\gamma)^{K_{2}}}{r^{K_{3}} \cdot V^{K_{4}}} \text { (мКм), }
$$

где $K_{1}, K_{2}, K_{3}, K_{4}$ - степенные коэффициенты, учитывающие влияние технологических величин на параметр шероховатости $R_{a} ; K_{0}$ - безразмерный поправочный коэффициент, меняющий свое значение при смене марки обрабатываемой стали и марки инструмента.

Недостатком приведенной зависимости (8) является то, что она имеет ограниченное применение по маркам обрабатываемых сталей (ст. 3 ; ст.20; ст.45; ст.70) и не учитывает влияние марки инструментального материала на величину $R_{a}$, а такое влияние имеется. 
Сравнение расчетных значений высоты микронеровностей по формуле (8) и измеренных показало значительные расхождения. Ошибка расчета составляла 70-120\%. При смене марки инструментального материала расхождение достигало двукратной величины.

В целях решения проблемы обеспечения точности расчета значения параметра шероховатости $R_{a}$ автоматизированным (программным) путем для токарной обработки углеродистых и конструкционных сталей была поставлена задача скорректировать расчетную модель путем введения в ее структуру дополнительной информационной величины о свойствах контактных пар. В качестве такого информационного фактора использовалась величина термоЭДС пробного прохода [17]. Скорректированная модель имеет вид:

$$
R_{a}=C_{R} \frac{S^{0,85}(90+\gamma)^{0,65}}{r^{0,36} \cdot V^{0,15}} \text { (мКм). }
$$

Коэффициент $C_{R}$ предложено определять как функцию от величины термо-э.д.с. пробного прохода для условий получистового точения по зависимости:

$$
C_{R}=0,474+0,11 E
$$

и для чистового точения:

$$
C_{R}=0,10+0,11 E .
$$

Введение в расчетную формулу (9) дополнительной информационной величины о свойствах контактных пар позволило снизить величину ошибки расчета $R_{a}$ до $12-15 \%$.

\section{Выводы}

1. На примере усовершенствования методик расчета скорости резания, составляющих силы резания и расчета величины шероховатости $R a$ путем введением в структуру моделей расчета дополнительной информативной величины о свойствах каждой контактной пары, экспериментально подтверждена концепция В. К. Старкова о повышении на этой основе надежности выбора режимов обработки.

2. Скорректированные расчетные модели скорости резания (1), прогнозирования стойкости инструмента (3), модели расчета составляющих силы резания (5), (6), (7) и величины шероховатости обработанной поверхности (9) могут быть использованы для построения алгоритмов их автоматизированного расчета в системах ЧПУ с дополнительными потоками информации.

\section{БИБЛИОГРАФИЧЕСКИЙ СПИСОК}

1. Иноземцев, А. Н. Оптимизация режима резания с учетом надежности инструмента / А. Н. Иноземцев, С. А. Васин, Н. И. Пасько // СТИН. - 2000. - № 10. - С. 31-3.

2. Старков, $B . K$. Физика и оптимизация режимов резания материалов / В. К. Старков. - М. : Машиностроение, 2009. - $640 \mathrm{c}$.

3. Плесков, В. Г. Разброс стойкости твердосплавного инструмента / В. К. Старков // РИТМ Машиностроения. 2018. - № 4. - С. 86-92.

4. Металлообрабатывающий твердосплавный инструмент : справочник / В. С. Самойлов, Э. Ф. Эйхманс [и др.]. - М. : Машиностроение, 1988. - 368 с.

5. Вульф, А. М. Резание металлов. - 2-е изд., перераб. и доп. / А. М. Вульф. - Л. : Машиностроение (Ленингр. отд-ние), 1973. - $496 \mathrm{c}$.

6. Подураев, В. Н. Активный контроль износа инструмента методом акустической эмиссии / В. Н. Подураев, А. А. Базаров, А. В. Сибальченко // Вестник машиностроения. - 1985. - № 4. - С. 14-19.

7. Заковоротный, В. Л. Построение информационной модели системы металлорежущего станка для диагностики процесса обработки / В. Л. Заковоротный, И. В. Ладник // Проблемы машиностроения и надежности машин. - 1991. № 4. - C. $75-81$.

8. Соломенщев, Ю. М. Способ определения режущих способностей инструментов. А. С. № 347629 - Б.И. 1971, № 8 .

9. Васильев, С. В. ТермоЭДС при резании как характеристика качества твердосплавных пластинок / С. В. Васильев // Станки и инструменты. - 1976. - № 5. - С. 27-28.

10. Трусов, $B$. В. Активная диагностика состояния режущего инструмента по контактной температуре резания / В. В. Трусов // Расчет режимов на основе общих закономерностей процесса резания : межвуз. сб. - Ярославль, 1982. - C. 86-95.

11. Корндор $\phi, C$. Ф. Термоэлектрический метод диагностики режущего инструмента / С. Ф. Корндорф, Е. Е. Мельник // Контроль. Диагностика - 2003. - № 1. C. $44-46$

12. Пат. 2063307 Россия, С1 6 В 23 В 25/06. Способ определения допустимой скорости резания при механической обработке детали твердосплавным инструментом / А. Л. Плотников. - Заявка № 94010673/08 от 29.03.94. Опубл. Бюл. №19 от 10.07.96.

13. Справочник технолога-машиностроителя. В 2 т. Т. 2 / под ред. А. Г. Косиловой и Р. К. Мещерякова. - 4-е изд. - М. : Машиностроение, 1985. - 496 с.

14. Епифанов, Г. И. Физика твердого тела : учеб. пособие / Г. И. Епифанов. - 2-е изд. перераб. и доп. - М. : Высш. школа, 1977. - 288 с.

15. Электрические и эмиссионные свойства сплавов / Е. М. Савицкий, М. В. Буров [и др.]. - М. : Наука, 1978. $294 \mathrm{c}$.

16. Пат. № 2120354 Россия, С1 В 23 В 25/06. Способ определения составляющих силы резания на токарных станках с ЧПУ / А. Л. Плотников, В. В. Еремеев. № 97116947/20; Заявлено 14.10.97; Бюл. № 29, 1998 .

17. Пат. 2492968 РФ, МПК В23В25/06. Способ определения параметра шероховатости на токарных станках с ЧПУ при получистовой и чистовой обработке металла твердосплавным инструментом / А. Л. Плотников, А. С. Сергеев, Н. Г. Зайцева ; ВолгГТУ. - 2013. 
УДК 621.923 .4

DOI: $10.35211 / 1990-5297-2021-8-255-42-46$

\title{
В. Н. Тышкевич, В. А. Носенко, А. В. Саразов, С. В. Орлов \\ УПРУГИЕ ДЕФОРМАЦИИ ПРИЗМАТИЧЕСКИХ ЗАГОТОВОК МАЛОЙ ЖЕСТКОСТИ ПРИ ПЛОСКОМ ШЛИФОВАНИИ
}

\author{
Волжский политехнический институт (филиал) ВолгГТУ \\ E-mail: mechanic@post.volpi.ru
}

Исследуется плоское шлифование боковых граней призматических заготовок малой жесткости. Разработана математическая модель максимальной упругой деформации призматических заготовок при закреплении и механической обработке. Учитываются контактные деформации поверхностей заготовки и стола станка. Проведена экспериментальная проверка разработанной модели.

Ключевые слова: плоское шлифование, упругие деформации, призматическая заготовка, малая жесткость.

\section{N. Tyshkevich, V. A. Nosenko, A. V. Sarazov, S. V. Orlov}

\section{ELASTIC DEFORMATIONS DURING FLAT GRINDING OF LOW-RIGIDITY PRISMATIC WORKPIECES}

\section{Volzhsky Polytechnical Institute (Branch) \\ Volgogradsky State Technical University}

The flat grinding of low-rigidity prismatic workpieces side surfaces is investigated. Mathematical models of the maximum elastic deformation of prismatic workpieces during fixing and machining have been developed. Contact deformations of the surfaces of the workpiece and the machine table are taken into account. An experimental verification of the developed models was carried out.

Keywords: flat grinding, elastic deformations, prismatic workpiece, low rigidity.

Рельсовые направляющие линейных подшипников качения, используемые для осуществления линейного перемещения подвижных узлов различных машин или устройств, являются одними из основных элементов конструкции, определяющими возможности и технический уровень оборудования [1]. Высокие требования к качеству обработанной поверхности боковых граней призматических направляющих обычно обеспечиваются плоским шлифованием. Упругие деформации в направлении перпендикулярном поверхности стола станка, возникающие при шлифовании боковых граней призматических заготовок малой жесткости, усложняют обеспечение требуемого допуска плоскостности обработанной поверхности. Величина максимальных упругих деформаций соизмерима с допуском плоскостности. После шлифования и снятия магнитного поля стола станка упругие деформации возвращают определенную величину отклонения от плоскостности, которое может превышать заданный допуск. Технологические способы их устранения значительно увеличивают время обработки и стоимость операции $[2,3]$.

Цель исследований: разработка математической модели максимальной упругой дефор- мации призматической заготовки малой жесткости при плоском шлифовании периферией круга с учетом силы резания, силы притяжения магнитного поля стола и изменения изгибной жесткости заготовки за счет использования компенсаторов; экспериментальная проверка разработанной модели.

Математическая модель максимальной упругой деформация заготовки при шлифовании определяется суммой деформаций:

$$
w_{\operatorname{maxn}}=w_{\mathrm{qn}}+w_{\mathrm{pn}}+w_{\mathrm{\kappa n}},
$$

где $w_{\mathrm{qn}}, w_{\mathrm{pn}}$ - составляющие максимального прогиба, от действия, соответственно, усилия притяжения магнитного поля стола станка и собственного веса заготовки, радиальной составляющей усилия резания в сечении максимального прогиба (с учетом соотношения жесткостей технологической системы $\left.c_{\mathrm{n}}[3]\right) ; w_{\text {кn }}$ контактная деформация в зависимости от числа пролетов.

Определение максимальных прогибов заготовок основано на теории изгиба балок, поэтому геометрические параметры заготовок должны удовлетворять ограничению: отношение длины заготовки к размеру поперечного сечения более 10. На основании экспериментальных

(C) Тышкевич В. Н., Носенко В. А., Саразов А. В., Орлов С. В., 2021. 
исследований показано, что заготовка получает изогнутость поверхности с выраженными волнами макроотклонений. Макроотклонение поверхности заготовки, соприкасающейся с поверхностью стола, моделируется цилиндрической поверхностью с направляющей в виде синусоиды с характерной длиной волны $l$ (рис. $1, a)$ [3]. Удвоенная амплитуда синусоиды $y_{a}$ принимается равной максимальной высоте волны макроотклонений (см. рис. 1, a). При закреплении заготовки магнитным полем стола на заготовку действует равномерно распределенная нагрузка интенсивностью: $q=q_{\mathrm{c}}+q_{\mathrm{m}}$, где $q_{\mathrm{c}}-$ интенсивность равномерно распределенной нагрузки от действия усилия притяжения магнитного поля стола станка; $q_{\mathrm{m}}$ - интенсивность равномерно распределенной нагрузки от действия собственного веса заготовки. При шлифовании добавляется радиальная составляющая силы резания $P_{\text {у }}$ в сечении, координата которого $x_{\operatorname{maxn}}$ определяется из условия максимального прогиба нераз- резной балки. Число пролетов балки $n=1+k$, где $k$ - число компенсаторов, которые используются для повышения изгибной жесткости заготовки (рис. $16, в)$.

По порядку решения [3], получим расчетные формулы для максимальных прогибов, координаты максимального прогиба $x_{\operatorname{maxn}}$, расстояния между точками касания поверхностей заготовки и стола станка $y_{\mathrm{n}}$ в сечениях с максимальными прогибами при различном числе пролетов для расчетных схем рисунка $1 a$, 6 , $в$ в виде:

$$
\begin{gathered}
w_{\mathrm{q} 1}+w_{\mathrm{p} 1}=\left(13 q l^{4}+20,8 c_{1} P_{y} l^{3}\right) \times 10^{-3} /\left(E I_{\mathrm{z}}\right) \\
x_{\max 1}=0,5 l ; y_{1}=y_{a}-w_{\mathrm{\kappa} 1} \\
w_{\mathrm{q} 2}+w_{\mathrm{p} 2}=\left(0,334 q l^{4}+1,89 c_{2} P_{y} l^{3}\right) \times 10^{-3} /\left(E I_{\mathrm{z}}\right) \\
x_{\max 2}=0,235 l ; y_{2}=0,451 y_{a}-w_{\mathrm{\kappa} 2} ; \\
w_{\mathrm{q} 3}+w_{\mathrm{p} 3}=\left(0,084 q l^{4}+0,63 c_{3} P_{y} l^{3}\right) \times 10^{-3} /\left(E I_{\mathrm{z}}\right) \\
x_{\max 3}=0,16 l ; y_{3}=0,233 y_{a}-w_{\mathrm{\kappa} 3} .
\end{gathered}
$$

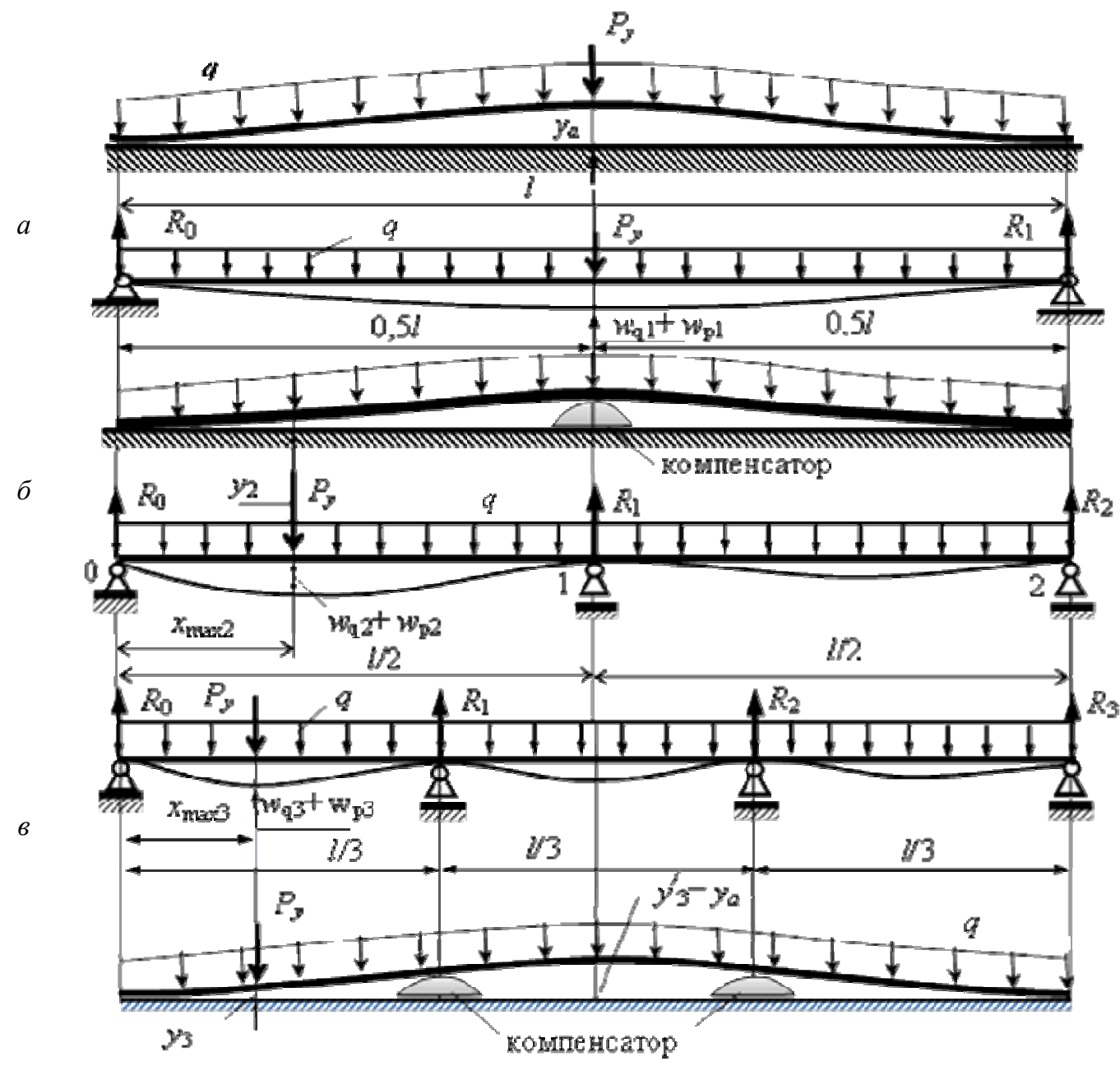

Рис. 1. Расчетные схемы заготовки при шлифовании с закреплением магнитным полем стола: $a$ - без компенсаторов; $\sigma$ - с одним компенсатором; $b$ - с двумя компенсаторами 
Методика и расчетные формулы для вычисления контактных деформаций описаны в [3, 4]. Для исследования упругих деформаций, возникающих при закреплении и шлифовании заготовки, выбрана направляющая роликового однорядного подшипника ЛРХ 6/350, изготавливаемая на ОАО «ЕПК Самара» из стали $20 \mathrm{X}$ (ГОСТ 4543 - 71) (рис. 2). Параметры макроотклонений, волнистости и шероховатости поверхности боковых граней определяли перед операцией чистового шлифования [3, 4]. Исследование отклонений от плоскостности выполняли на поверхности грани $A$ (см. рис. 2), которая в дальнейшем используется как базовая. Исследовали отклонения грани $A$ на пяти заготовках. Измерения выполняли индикаторной головкой со шкалой деления 1 мкм (ГОСТ 9696-82) при продольном перемещении стола станка, шаг измерений -25 мм.

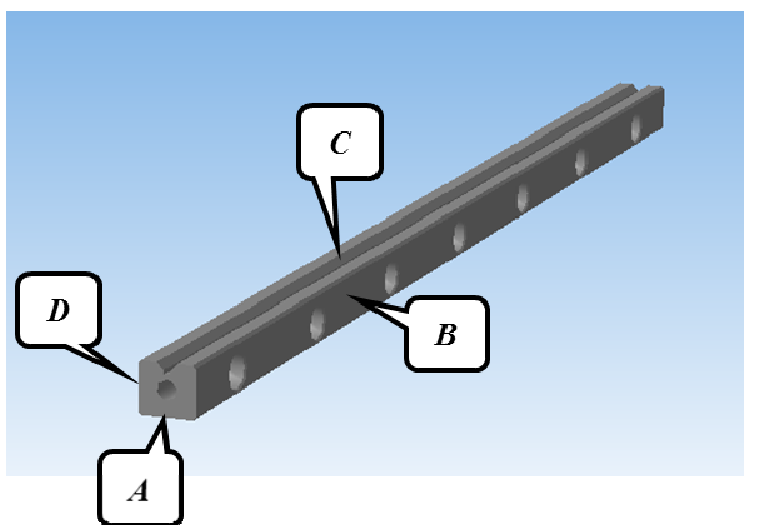

Рис. 2. Обозначение граней направляющей подшипника ЛРХ 6/350

При дальнейших исследованиях заготовку положили на поверхность стола станка гранью $A$, при этом заготовка касается поверхности стола наиболее выступающими поверхностями (рис. 3).

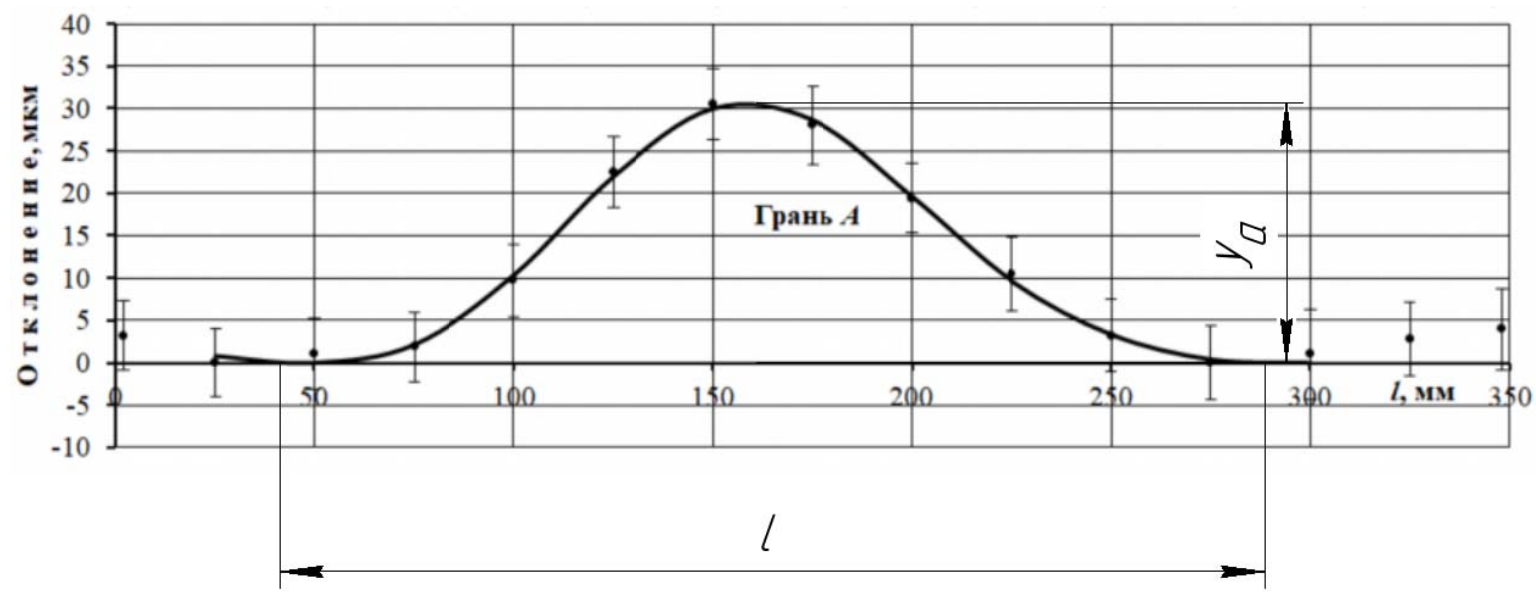

Рис. 3. Параметры синусоиды

Количество параллельных измерений - 3 (по ширине заготовки), количество опытов для одной заготовки - 15 . Направляющая цилиндрической поверхности, которой моделируется поверхность грани $A$, контактирующей с поверхностью стола, близка к синусоиде. После аппроксимации фактической кривой усредненной заготовки методом наименьших квадратов получим синусоиду, представленную на рис. 3. Результаты измерений амплитуды и характерной длины волны для пяти заготовок представлены в табл. 1.

Таблииа 1

Результаты измерений параметров синусоиды

\begin{tabular}{|c|c|c|c|c|}
\hline $\begin{array}{c}\text { № } \\
\text { заготовки }\end{array}$ & $y_{a}$, мкм & $\begin{array}{c}\text { Погрешность измерений, } \\
\delta, \text { мкм }\end{array}$ & $l$, мм & $\begin{array}{c}\text { Погрешность измерений, } \\
\delta, \text { мм }\end{array}$ \\
\hline 1 & 31 & 3,75 & 247 & 5,7 \\
\hline 2 & 32 & 3,75 & 248 & 5,7 \\
\hline 3 & 26 & 3,75 & 239 & 5,7 \\
\hline 4 & 28 & 3,75 & 242 & 5,7 \\
\hline 5 & 33 & 3,75 & 250 & 5,7 \\
\hline Среднее & 30 & 3,75 & 245 & 5,7 \\
\hline
\end{tabular}


Адекватность замены реальной поверхности цилиндрической с направляющей в виде синусоиды проверена по критерию Фишера, дисперсии адекватности и воспроизводимости однородны. Экспериментально проверяли максимальную деформацию заготовки от действия усилия притяжения магнитного поля стола станка. Заготовку кладем на стол гранью $A$. Устанавливаем индикаторную головку на грань $C$ в сечении, соответствующем середине характерной длины волны синусоиды (см. рис. 1, $a$, рис. 3). В соответствии с результатами измерения пяти заготовок, представленными в табл. 1 минимальный размер зазора между поверхностью заготовки и стола станка равен 26 мкм. Величина удельного усилия притяжения маг- нитного поля стола станка, определена из условия не превышения величины максимальной деформации 26 мкм и равна $p=0,02$ МПа. Расчет максимальной упругой деформации $w^{\mathrm{p}}{ }_{\max }$ производили в соответствии с математической моделью $(1,2)$, учитывая интенсивность равномерно распределенной нагрузки от действия магнитного поля и контактную деформацию. Экспериментальное значение максимальной деформации $w_{\max 1}^{{ }^{3}}$ определяли по показаниям индикаторной головки. Результаты сведены в табл. 2. Экспериментально измеренные максимальные перемещения исследованных заготовок имеют относительные погрешности от теоретических не превышающие 17 \%. Средняя относительная погрешность составляет $11 \%$.

Таблииа 2

Максимальная деформация заготовки от действия усилия притяжения магнитного поля стола станка $(p=0,02$ МПа)

\begin{tabular}{|c|c|c|c|c|}
\hline $\begin{array}{c}\text { № } \\
\text { заготовки }\end{array}$ & $\begin{array}{c}\text { Экспериментальная } \\
\text { максимальная } \\
\text { деформация } \\
w_{\text {max }} \text {, мкм }\end{array}$ & $\begin{array}{c}\text { Погрешность } \\
\text { измерений, } \\
\delta, \text { мкм }\end{array}$ & $\begin{array}{c}\text { Рассчитанная величина } \\
\text { максимальной } \\
\text { деформации } \\
w_{\text {max }}^{\mathrm{p}}, \text { мкм }\end{array}$ & $\begin{array}{c}\text { Относительная } \\
\text { погрешность } \\
\delta, \%\end{array}$ \\
\hline 1 & 20 & 1,5 & 22 & 10 \\
\hline 2 & 19 & 1,5 & 23 & 17 \\
\hline 3 & 18 & 1,5 & 20 & 10 \\
\hline 4 & 19 & 1,5 & 21 & 4,3 \\
\hline 5 & 23 & 1,5 & 24 & 11 \\
\hline Среднее & 19,8 & 1,5 & 22 & \\
\hline
\end{tabular}

Проверяем адекватность математической модели по критерию Фишера при 5\% уровне значимости. Дисперсия адекватности, зависящая от разности между значениями параметра, определенными по математической модели, и экспериментальными результатами определения параметра, по численным значениям таблицы 2 [5]: $S_{a d}^{2}=29 / 5=3,7$. В качестве дисперсии воспроизводимости берем дисперсию ряда экспериментально определенных максимальных деформаций пяти заготовок с числом степеней свободы $f_{\text {воспр }}=5: S_{\text {вocnp }}^{2}=3,7$. Расчетный коэффициент Фишера: $F=5,8 / 3,7=1,57$. Полученное отношение сравниваем с табличным: $F_{1-p}\left(f_{1}, f_{2}\right)$, где уровень значимости $p=0,95$; число степеней свободы дисперсии адекватности $f_{1}=5$; число степеней свободы дисперсии воспроизводимости $f_{2}=5$. Таким образом, $F_{\text {табл }}=5,05[5]$.

Выполнено условие $F<F_{\text {табл, }}$ следовательно, дисперсии адекватности и воспроизводи- мости однородны, математическая модель адекватна

\section{Выводы}

Разработана математическая модель максимальной упругой деформации призматической заготовки малой жесткости при плоском шлифовании с учетом силы резания, силы притяжения магнитного поля стола и изменения жесткости заготовки при использовании компенсаторов. Экспериментальная проверка подтверждает адекватность разработанной модели.

\section{БИБЛИОГРАФИЧЕСКИЙ СПИСОК}

1. Лурье, А. М. Рельсовые направляющие качения. Характеристики продукции разных производителей. Рекомендации по применению : обзор. исслед. / А. М. Лурье ; ОАО «ЭНИМС», ЗАО «Сервотехника». - 2006. - 50 с.

2. Справочник технолога / под общ. ред. А. Г. Суслова. - Москва : Инновационное машиностроение, 2019. $800 \mathrm{c}$.

3. Тышкевич, В. H. Simulation of maximum elastic deformations during flat grinding of low-rigidity prismatic workpieces / В. Н. Тышкевич, А. В. Саразов, С. В. Орлов // 
IOP Conf. Series: Materials Science and Engineering. Vol. 971 022048: International Conference on Modern Trends in Manufacturing Technologies and Equipment 2020 (ICMTME 2020) (Sevastopol, 7-11 September, 2020). - [IOP Publishing], 2020. -8 p. - URL : https://iopscience.iop.org/ article/10.1088/1757-899X/971/2/022048/pdf.

4. Определение контактных деформаций при плоском шлифовании торцов колец крупногабаритных подшипников / В. А. Носенко, В. Н. Тышкевич, А. В. Саразов, С. В. Орлов // Фундаментальные и прикладные проблемы техники и технологии. - 2016. - № 6 (320). - С. 50-54.

5. Спиридонов, $A$. A. Планирование эксперимента при исследовании технологических процессов / А. А. Спиридонов. - М. : Машиностроение, 1981. - 184 с.

DOI: $10.35211 / 1990-5297-2021-8-255-46-48$

Е. А. Федянов, В. А. Санинский, Н. А. Ушаков

\section{МЕТОДИКА РАСЧЕТА КОЛИЧЕСТВА ДРОССЕЛИРУЮЩИХ ЭЛЕМЕНТОВ МНОГОЗУБОГО ДОРНА}

\section{Волжский политехнический институт (филиал) ВолгГТУ}

E-mail: ushakov@post.volpi.ru

Предложена методика расчета параметров цилиндрических дросселирующих элементов дорнующих зубьев многозубого дорна, которая позволяет обеспечить необходимый объем и распределение потока рабочей среды, подаваемый на дорн в процессе обработки глубоких отверстий длинномерных цилиндров, и обосновать разделение общего потока на несколько различных потоков, обеспечивающих дросселирование смазывающее-охлаждающей жидкости (СОЖ) при ее применении в смазочно-охлаждающей технологической среде (СОТС). Предполагается, что обработка осуществляется на принципах совмещения процессов вихрефрезерования и поверхностной пластической деформации (ППД) способами и методом винтовой интерполяции. Результаты исследований на основе разработанной методики расчета расхода рабочей среды в цилиндрических дросселирующих элементах позволяют обеспечивать дальнейшее совершенствование существующих способов обработки глубоких отверстий, в том числе повышение качества особоточных точных труб.

Ключевые слова: дросселирующие зубья; режущий зуб; глубокое отверстие; пластическая деформация.

\section{E. A. Fedyanov, V. A. Saninsky, N. A. Ushakov}

\section{METHOD FOR CALCULATING THE NUMBER OF THROTTLE ELEMENTS OF THE MULTI-TOOTH DORN}

\section{Volzhsky Polytechnic Institute (branch) of VSTU}

The method for calculating the parameters of the cylindrical throttling elements of the tipping teeth of a multitoothed mandrel has been performed, which makes it possible to provide the required volume and distribution of the working medium flow supplied to the mandrel in the process of processing deep holes of long cylinders and to substantiate the division of the total flow into several different streams that provide throttling of the lubricating cooling liquid (Coolant) when used in a lubricating and cooling technological environment (SOTS). It is assumed that the processing is carried out on the principles of combining the processes of vortex milling and surface plastic deformation (SPD) by the methods and method of helical interpolation presented in the description of the monograph. The research results based on the developed methodology for calculating the flow rate of the working medium in cylindrical throttling elements allows for further improvement of existing methods for processing deep holes, including improving the quality of high-precision precision pipes.

Keywords: throttling teeth; cutting tooth; deep hole; plastic deformation.

Известны способы механической обработки глубоких отверстий (ГО) в длинномерной трубных заготовках (Т3), при осуществлении которых обработку осуществляют устройством, содержащем борштангу с режущим инструментом [1-3].

При обработке ГО 1 (рис. 1, 2) в ТЗ 2 борштанга 3 (рис. 1) может быть оснащена резцом 4 (или фрезой), располагаться на эксцентричных подшипниках 5 в пиноли 6 с передним ре- жущим зубом 7 и дорнующими зубьями 8 , содержащей переднюю крышку 9, заднюю крышку 1 . На входе в глубокое отверстие 1 трубной заготовки 2 выполняют расточку 11 длиной не менее длины пиноли 6 . Пиноль 6 базируют в исходном положении в расточке 11 перед включением давления $\mathrm{P}$ рабочей среды для осуществления осевой подачи пиноли 6 вдоль оси ГО. По наружной поверхности на концах трубной заготовки 2 предварительно

(C) Федянов Е. А., Санинский В. А., Ушаков Н. А., 2021. 
нарезают резьбу 12, с помощью которой на торцах трубной заготовки фиксируют левую 13 и правую 14 заглушки с дросселями 15. При этом образуется единая герметичная полость между левой 13, правой 14 заглушками и поверхностью ГО 1. Для осуществления прямого рабочего хода до выхода пиноли 6 к правой заглушке 14, рабочую среду подают под давлением Р по трубопроводу 16 через дроссель 15 левой заглушки 13 в герметичную полость и далее через дроссель вращения 17 на турбину 18. При этом борштанга 3 осуществляет поступательное и вращательное движение. За счет того, что подшипники 5 имеют эксцентриситет, возможно совмещение поступательного и вращательного движении с планетарным движением борштанги 3 вокруг оси пиноли 6, выполняя растачивание ГО под последующее совмещенное с растачиванием, протягивание передним режущим зубом 7 и дорнование глубокого отверстия 1 дорнующими зубьями 8 . В процессе дорнования смазывающее-охлаждающая среда, которой может являться турбинное масло, подаваемое по трубопроводу 10 , подается по радиальным каналом 19 и 20 на дросселирующие элементы радиусом r общим количеством $\mathrm{n}$ между дорнующими зубьями 8 , расположенные по периметрам дросселирующих зубьев 8 (рис. 2).

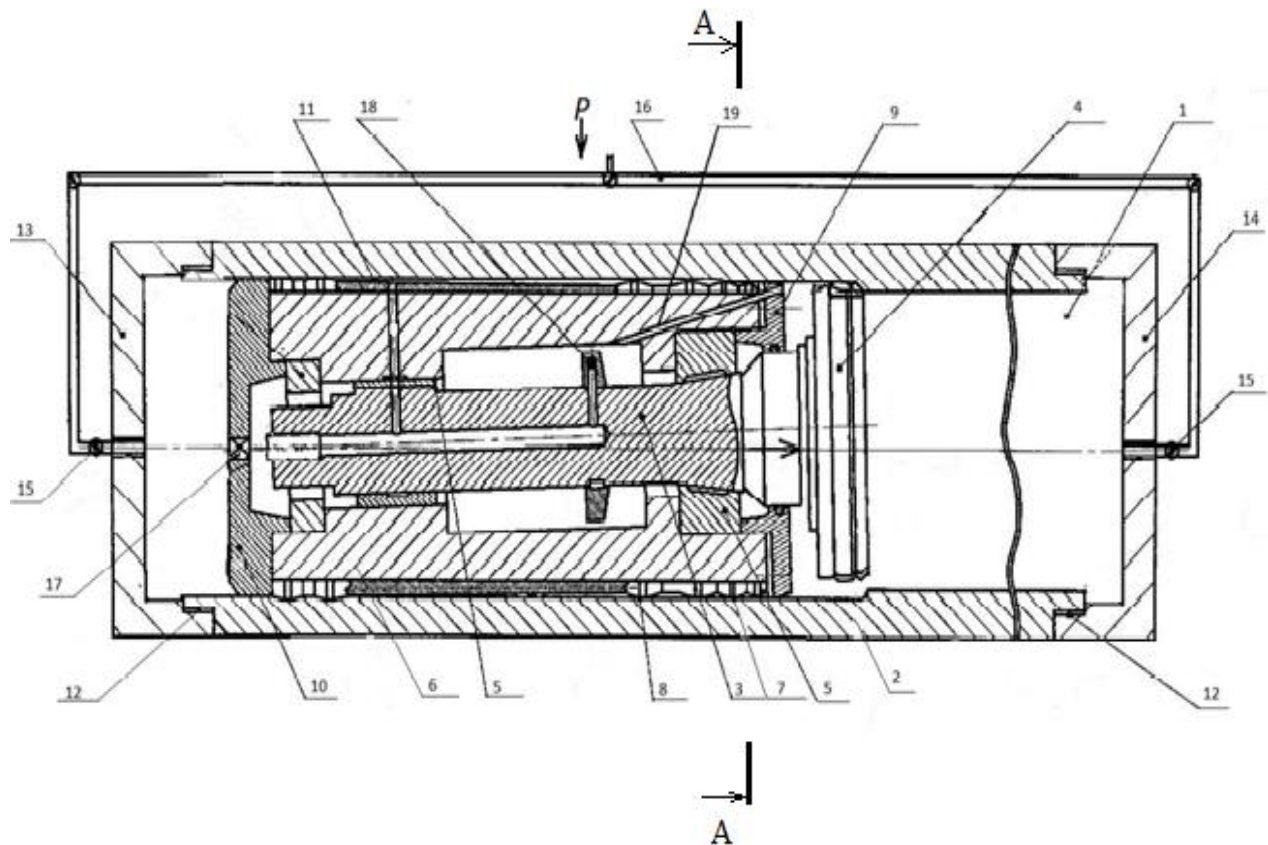

Рис. 1. Продольное сечение устройства для механической обработки глубокого отверстия в трубной заготовке, применяемое при осуществлении способа [3]

По окончании процесса такой совмещенной обработки ГО осуществляют обратный ход на рабочей подаче, для чего рабочую среду подают через дроссель 15 правой заглушки 14 до полного возврата пиноли 6 к заглушке 13 в исходное положение. При этом осуществляется повторное дорнование обрабатываемого глубокого отверстия 1 в пределах остаточной деформации поверхности ГО

Используем следующие исходные данные из статьи [6].

Приравняем параметры цилиндрических дросселирующих элементов (число $\mathrm{N}$ ц. д. э которых нужно рассчитать) и параметры четырех щелевых канавок: высота 0,0005 м, ширина 0,007 м. Определенную в статье [6] скорость движения дорна относительно стенки трубы $\mathrm{V}_{\text {д }}=1,2 \mathrm{~m} /$ мин требуется оставить неизменной

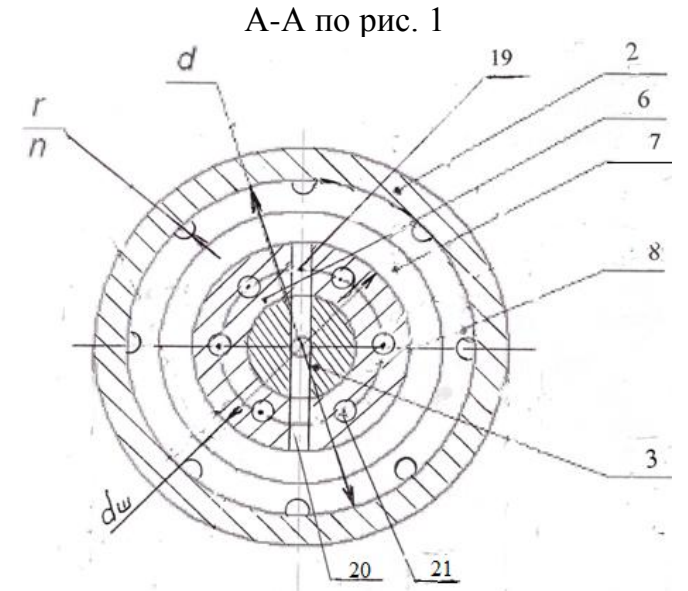

Рис. 2. Вид дросселирующих элементов на поперечном сечении пиноли 6: 2 - обрабатываемая трубная заготовка; 3 - шпинель: 6 - пиноль: 8 - дросселирующие элементы дорнующих зубьев; 7 - режущий зуб: 21 - осевые каналы для подвода СОЖ к радиальным каналам 19 и 20 
как и длину потока в щели 1 мм х $12=12$ мм, используемая СОЖ - масло, динамическая вязкость СОЖ 12,6 МПА·с; давление СОЖ в полости трубы $\mathrm{P}_{60} \sum \mathrm{B} 60=364440(\mathrm{H})$.

Подставив численные значения в формулу (1), получим:

$$
V_{\text {д }}=\frac{2}{0,5 \cdot 10^{-3} \cdot 7 \cdot 10^{-3}} \cdot\left(\frac{0,5 \cdot 10^{-3} \cdot 7 \cdot 10^{-3} 30,4 \cdot 10^{6}}{12 \cdot 12,6 \cdot 10^{6}}\right.
$$

Диаметр прошивки 105 мм [1] позволяет определить диаметр гидроцилиндра, в котором нужно с усилием перемещать дорн-поршень. Используя эти данные расчета достигаемого усилия дорнования прошивкой дорном диаметром 105 мм и характеристик СОТС - глубина 0,5 мм, длина 7 мм [3, 4] по четыре канавки на каждые 12 зубьев и необходимого давления и расхода СОЖ при скорости дорнования 1 м/мин $[2,5,6]$.

Зная величину силы $\mathrm{P}_{60} \sum \mathrm{B} 60=121480$ х3= $=364440(\mathrm{H})$, необходимой для осуществления дорнования ГО диаметром $60 \mathrm{H7}$, имеющего перед обработкой припуск $0,9=1,4$; мм, необходимо установить давление $p_{\text {сож}}$, которое необходимо создать для перетекания СОЖ из обрабатываемой полости ГО в отработанную [2].

Скорость перемещения дорна (резания) может быть выражена через параметры давления $\Delta p_{\text {д }}$ и геометрические параметры $\delta$ и $b$ дросселирующих элементов щелей и обрабаты-ваемого отверстия через следующую зависимость [6].

$$
V_{\text {д }}=\frac{2}{\delta b}\left(\frac{\delta b \cdot \Delta p_{\text {д }}}{12 \mu L}-\frac{\pi \cdot \mathrm{D}^{2}}{4} \cdot L_{0} \cdot N\right),
$$

где $V_{\text {д }}$-скорость движения дорна относительно стенки трубы, $\delta$ - высота щели (0,0005 м), b ширина щели $(0,007$ м), $L$ - длина потока в щели (1 мм х $12=12$ мм), $\mu$ - динамическая вязкость СОЖ (12,6 МПА·c), $N$ - число щелей в дорнующем зубе (4 или кратное 4$), \Delta p_{д}$ - перепад давлений при продавливании СОЖ через щели зуба, $L_{0}$ - длина обрабатываемого отверстия $\left(L_{0}=1\right.$ м.). При этом значения регулируют на ве-

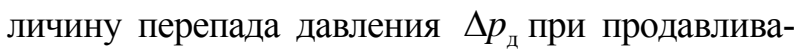
нии СОЖ через щелевые канавки зуба в зависимости от режимов резания, что позволяет снизить процессы образования нароста на дорнующих зубьях и задиров на обработанной поверхности.

Однако, для дросселирующих элементов цилиндрической формы с радиусом $\mathrm{r}=0,5$ мм эта зависимость не всегда соответствует требованиям к выкружкам, выполняемым на протяжках.

$$
\Delta p_{\text {д }}=\frac{121,5-0,1}{4}=30,4 M \Pi a .
$$

Зная перепад давлений при продавливании СОЖ через щели зуба, используя формулу (2), найдем значение $V_{\text {д }}$ :

$\left.-\frac{3,14 \cdot\left(6 \cdot 10^{-2}\right)^{2}}{4} \cdot 1 \cdot 4\right)=0,02 м /$ сек $=1,2 м / м и н$

$V_{\text {Д }}=\frac{2}{\delta b}\left(\frac{\delta b \cdot \Delta p_{\partial}}{12 \mu L}-\frac{\pi \cdot D^{2}}{4} \cdot L_{0} \cdot N-\frac{4 r^{2}-\pi r^{2}}{2} \cdot N\right)$.

После преобразования формула (3) примет вид:

$V_{\text {Д }}=\frac{2}{\delta b}\left(\frac{\delta b \cdot \Delta p_{\partial}}{12 \mu L}-\frac{N}{2} \cdot\left(\frac{\pi \cdot D^{2}}{2} \cdot L_{0}-r^{2} \cdot(4-\pi)\right)\right)$.

Подставив численные значения в формулу (3), получаем значение $V_{\text {д }}$ равное 1,2 м/мин.

\section{Выводы}

1. Осевая скорость дорна зависит от методики расчета параметров дросселирующих элементов на дорнующих зубьях.

2. Выполненная методика расчета параметров цилиндрических дросселирующих элементов дорнующих зубьев позволяет создать возможности для методического обеспечения расчетного распределение потока рабочей среды, подаваемый на многозубый дорн-поршень, а также на несколько различных потоков, обеспечивающих дросселирование СОЖ в СОТС.

\section{БИБЛИОГРАФИЧЕСКИЙ СПИСОК}

1. Санинский, В. А. Обоснование расширения возможностей режуще-деформирующего прошивания глубоких отверстий при ремонте машин сельскохозяйственного назначения / В. А. Санинский, А.В.Грибенченко, Е. Н. Смирнова // Известия Нижневолжского агроуниверситетского комплекса: наука и высшее профессиональное образование. - 2019. - № 1 (53). - С. 284-293.

2. Протяжки для обработки отверстии / Ж. К. Маргулис, М. М. Тверской, В. Н. Ашихмин [и др.]. - М. : Машиностроение, 1986. - 232 с., с ил. - (Б-ка инструментальщика).

3. Пат. 2563401 РФ, МПК В23В35/00. Способ механической обработки глубокого отверстия в трубной заготовке / В. А. Санинский, В. В. Ананян, Е. Н. Осадченко, А. В. Санинский, Д. Н. Творогов ; ВолгГТУ. -2015.

4. Inproving the use jf lubricfnd fnd cjjlant fluida in machining/ A, V Shchedrin? F. F. Bekaev. V, M. Skoromnv et al // Russian Engineering Restarch. Nef Vork; Allerton press, 2006, Vol. 26. № 10. 3 38-39

5. Санинский, В. А. Расчет параметров дросселирования каналами дорнующих элементов прошивок / В. А. Санинский, Е. А. Федянов, Е. Н. Нестеренко // Известия ВолгГТУ : научный журнал № 2 / ВолгГТУ. - Волгоград, 2020. - (Серия «Прогрессивные технологии»).

6. Федянов, E. A. Расчет параметров дросселирования в параллельных каналах дорнующих прошивок для глубоких отверстий / Е. А. Федянов, В. А. Санинский, Н. А. Ушаков // Известия ВолгГТУ : научный журнал № 1 / ВолгГТУ. - Волгоград, 2021. - (Серия «Прогрессивные технологии»). 


\section{АВТОМАТИЗАЦИЯ ПРОИЗВОДСТВЕННЫХ ПРОЦЕССОВ}

УДК 633.522:631.352.5

DOI: $10.35211 / 1990-5297-2021-8-255-49-51$

Д. Ю. Абалхан, Я. В. Калинин, Н. А. Сурганов, Р. А. Чигвинцев

\section{РАЗРАБОТКА ПЕРВОГО ЯРУСА ПРИЦЕПНОГО КОНОПЛЕУБОРОЧНОГО КОМБАЙНА}

\section{Волгоградский государственный технический университет \\ E-mail: app@vstu.ru}

В настоящее время, когда с каждым годом проблем с экологией становится больше, человечество находится в поиске экологически чистых продуктов. Таковым является техническая конопля. Данная статья посвящена разработке первого яруса прицепного коноплеуборочного комбайна, работающего с трактором Кировец К-744. Приведены преимущества и недостатки разрабатываемой установки.

Ключевые слова: техническая конопля, комбайн, сельское хозяйство.

\section{Yu. Abalkhan, Ya. V. Kalinin, N. A. Surganov, R. A. Chigvintsev \\ DEVELOPMENT OF THE FIRST TIER OF A TRAILED HEMP HARVESTER \\ Volgograd State Technical University}

At present, when every year there are more problems with the environment, humanity is in search of environmentally friendly products. Such is technical cannabis. This article is devoted to the development of the first tier of a trailed hemp harvester working with the Kirovets K-744 tractor. The advantages and disadvantages of the developed installation are given.

Keywords: technical hemp, combine harvester, agriculture.

В настоящее время, когда люди уделяют большее значение окружающему миру, выросла нужда в производстве экологически чистых продуктов. Одной из таких культур является конопля. Во всем мире производство технической конопли ценится наравне с производством съедобных культур. В России за последние три года наблюдается рост производства культурной конопли, но цифры конечного продукта пока несравнимы с зарубежными коллегами. Это связанно с проблемами сельскохозяйственного сектора России. Эти проблемы затрагивают не только коноплеводство, но и весь сектор целиком.

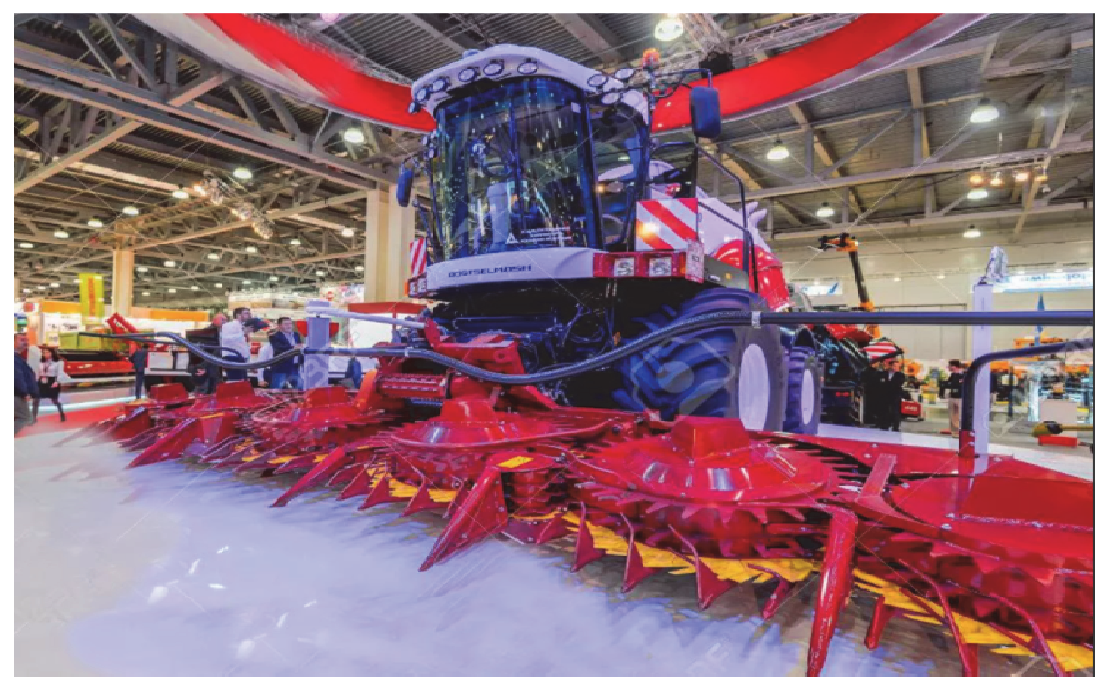

Рис. 1. Комбайн RSM F 2450 компании «Ростсельмаш»

( С Абалхан Д. Ю., Калинин Я. В., Сурганов Н. А., Чигвинцев Р. А., 2021. 
Компания «Ростсельмаш» в 2020 году начала испытания, модернизированного под уборку конопли комбайна RSM F 2450 с роторной жаткой ЖР-600 $[1,2]$. Благодаря изменениям, ожидаемая производительность комбайна составит 20-30 га в смену. Так как разработка техники для коноплеводства началась компанией недавно, конкурировать с заграничными аналогами комбайны пока неспособны.

Отечественная техника представлена устаревшими машинами, а новые модели машин только начинают разрабатываться большими машиностроительными российскими компаниями. Машины советского производства низкопроизводительны, требуют большого количества обслуживающего персонала. Машины нового поколения требуют доработок, чтобы конкурировать на рынке.
Коноплеуборочные комбайны, производимые за рубежом, отличаются высокой производительностью, качеством самих аппаратов. Недостатком является дороговизна машин. Поэтому такие комбайны могут приобрести только большие фирмы.

Данная статья посвящена разработке первого яруса прицепного коноплеуборочного комбайна.

Движущей силой данного комбайна является трактор. В табл. 1 приведена сравнительная характеристика тракторов. Были рассмотрены Кировец К-744, АГРОМАШ 180ТК, Terrion АТМ 7360, КамАЗ XEX 215 [3, 4, 5, 6]. Оценка тракторов производилась по следующим параметрам:

$$
\begin{aligned}
& \text { - стоимость; } \\
& \text { - мощность; } \\
& \text { - импортозамещение. }
\end{aligned}
$$

Таблий 1

Сравнительная характеристика отечественных тракторов

\begin{tabular}{|l|c|c|c|c|}
\hline \multicolumn{1}{|c|}{ Показатель } & $\begin{array}{c}\text { КИРОВЕЦ } \\
\text { К-744 }\end{array}$ & $\begin{array}{c}\text { АГРОМАШ } \\
180 \text { ТК }\end{array}$ & $\begin{array}{c}\text { Terrion } \\
\text { АТМ 7360 }\end{array}$ & $\begin{array}{c}\text { КамА3 } \\
\text { ХТХ 215 }\end{array}$ \\
\hline Цена млн. руб. & 4 & 2,3 & 7,9 & 5,4 \\
\hline Максимальная мощность (л/с) & 279 & 181 & 360 & 230 \\
\hline Грузоподъемность (т) & 8,5 & 7,5 & 13,5 & 11 \\
\hline
\end{tabular}

Проведя анализ машин по заданным параметрам, был выбран трактор Кировец К-744. Этот трактор отличается хорошей ремонтопригодностью. Произвести техническое обслуживание машины сможет даже начинающий механик. Для поддержания машины в рабочем состоянии достаточно опыта и сил собственных автомастерских, которые есть в сельском хозяйстве. Трактор Кировец К-744 имеет простую и надежную конструкцию. В ходе создания машины разработчики исключили недостатки предшественников и максимально адаптировали трактор к отечественным условиям.

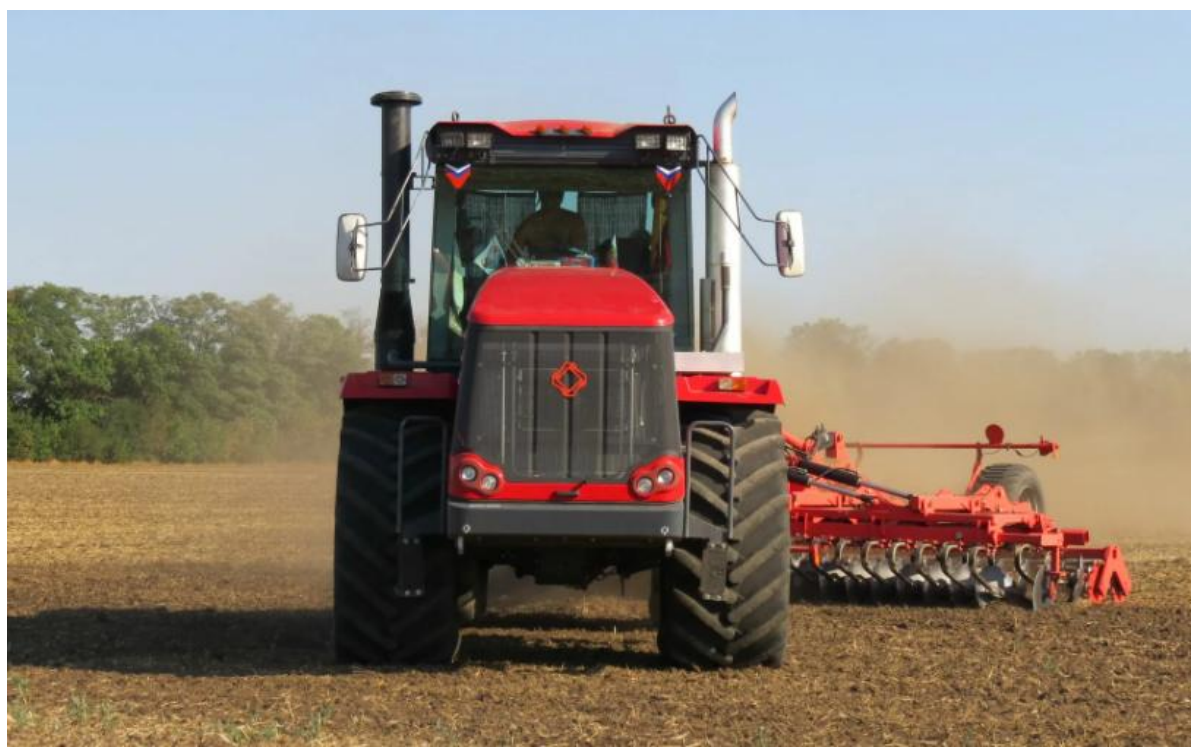

Рис. 2. Трактор Кировец К-744 
При разработке трактора инженеры учли такие факторы, адаптация к некачественному дизельному топливу, высокоразвитая сервисная база по всей стране, с необходимыми запчастями, и адаптация к любым видам почв, включая твердый целинный грунт.

Принцип работы разрабатываемого комбайна заключается в его креплении через осевой вал к трактору (от которого комбайн будет получать крутящий момент для осуществления работы) и движения вместе с ним. Для срезания стеблей конопли используются специальные, острозаточенные дисковые пилы. После срезания стебель попадает на платформу, имеющую перемещающий механизм, и выпадает из задней части установки. Итогом работы являются срезанные стебли технической конопли для последующей сборки и переработки.

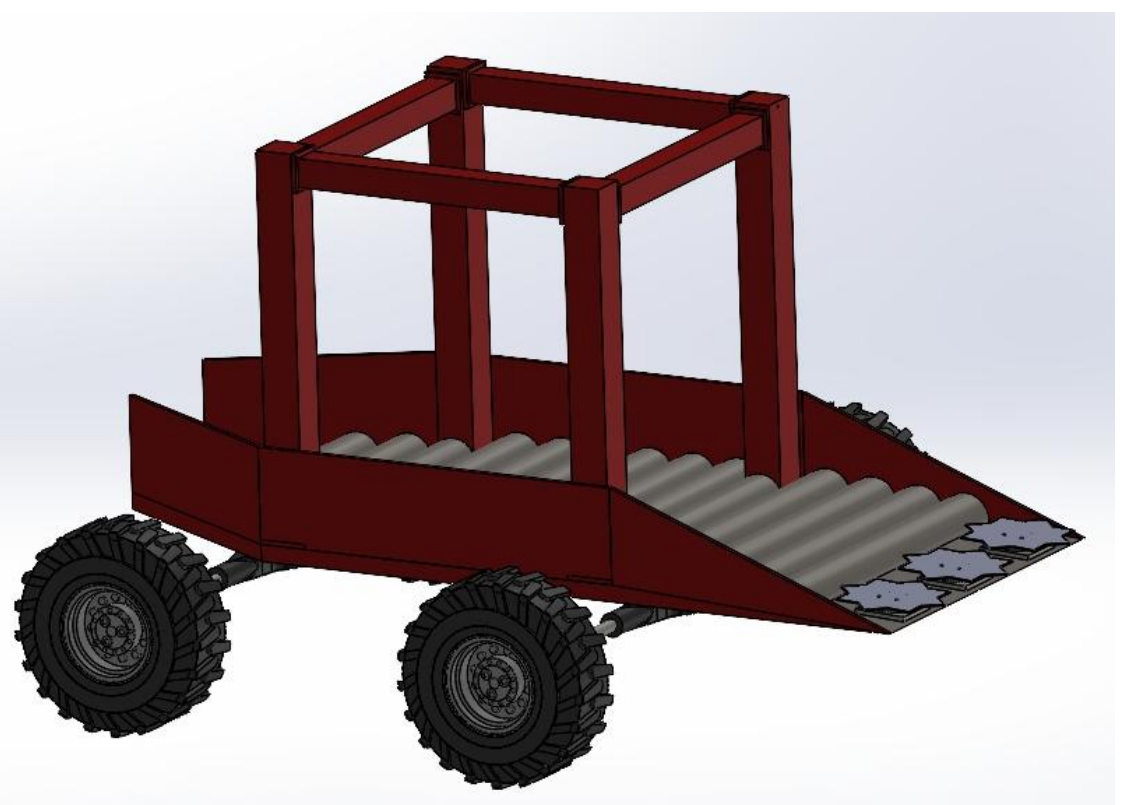

Рис. 3. Концепт первого яруса разрабатываемого комбайна

Перспективы. Следующим этапом разработки является второй ярус комбайна, на котором будет осуществляться срезания головок стебля с семенами и их сбор.

Вывод. Выбор данной конструкции обусловлен следующими факторами:

1) простота конструкции;

2) дешевизна и универсальность установки;

3) у разрабатываемого комбайна прочный корпус, который выдержит нагрузки от кожуха приводного вала;

Недостатки данной установки:

- невозможность работы с маломощными тракторами;

- в местах зацепления приводного вала, передающего крутящий момент от трактора к установке, будет происходить потеря мощности из-за того, что этот вал будет закреплен под углом относительно продольной оси трактора;

- узел крепления трактора и установки будет испытывать большие нагрузки на кручение в местах закрепления, а сам кожух вала в местах крепления будет испытывать нагрузки на изгиб.

\section{БИБЛИОГРАФИЧЕСКИЙ СПИСОК}

1. Ростсельмаш поможет лубяной отрасли [Электронный ресурс] // Рослёнконопля : официальный сайт - 2021 Режим доступа : https://www.rosflaxhemp.ru/zhurnal/daty-ipozdravleniya.html/id/4062 (дата обращения 16.02.2021).

2. Испытания на конопле комбайна RSM F 2450 [Электронный ресурс] // Рослёнконопля: официальный сайт - 2021 - Режим доступа : https://www.rosflaxhemp.ru/ news.html/id/3763 (дата обращения 16.02.2021).

3. Трактор Кировец К-744 [Электронный ресурс] // Трактордом : официальный сайт - 2021 - Режим доступа : https://traktordom.ru/traktor-kirovec-k-744-texnicheskie-xarakteristiki-osobennosti-ustrojstva-i-cena/ (дата обращения 26.06.2021).

4. Трактор Terrion ATM 7360 [Электронный ресурс] // Трактордом : официальный сайт - 2021 - Режим доступа : https://traktordom.ru/traktor-terrion-atm-7360-texnicheskiexarakteristiki-osobennosti-ustrojstva-i-cena/ (дата обращения 26.06.2021).

5. Трактор АГРОМАШ 180 ТК[Электронный ресурс] // Трактордом : официальный сайт - 2021 - Режим доступа : https://traktordom.ru/traktor-agromash-180tk-texnicheskie-xarakteristiki-osobennosti-ustrojstva-i-cena/ (дата обращения 26.06.2021).

6. Трактор КамАЗ ХТХ 215 [Электронный ресурс] // Обзор тракторов : официальный сайт - 2021 - Режим доступа : https://tractorreview.ru/traktory/kamaz/traktor-kamazhth-215-tehnicheskie-harakteristiki.html (дата обращения 26.06.2021). 
УДК 629.1.02

DOI: $10.35211 / 1990-5297-2021-8-255-52-54$

\title{
Д. В. Бордюгов ${ }^{1}$, С. С. Фоменко ${ }^{1}$, А. В. Малолетов ${ }^{1,2}$, Е. С. Брискин ${ }^{1}$
}

\section{ЛАБОРАТОРНАЯ МОДЕЛЬ МОБИЛЬНОГО РОБОТА С СЕКЦИОННЫМ ДВИЖИТЕЛЕМ*}

${ }^{1}$ Волгоградский государственный технический университет

${ }^{2}$ Центр технологий компонентов робототехники и мехатроники, Университет Иннополис

E-mail: dtm@vstu.ru

Рассмотрена лабораторная модель и моделирование движения мобильного робота с секционным движителем. Представлены результаты математического моделирования динамики движения.

Ключевые слова: мобильный робот, секционный движитель, математическая модель.

$$
\text { D. V. Bordugov }{ }^{l} \text {, S. S. Fomenko }{ }^{1} \text {, A. V. Maloletov }{ }^{1,2} \text {, E. S. Briskin }{ }^{1}
$$

\section{LABORATORY MODEL OF MOBILE ROBOT WITH SECTIONAL MOVER}

\author{
${ }^{1}$ Volgograd State Technical University \\ ${ }^{2}$ Center for Technology Components of Robotics and Mechatronics, Innopolis University
}

A laboratory model and simulation of the movement of a mobile robot with a sectional propeller are considered. The results of mathematical modeling of motion dynamics are presented.

Keywords: mobile robot, dynamics, sectional mover, mathematical model.

Разработка и исследование адаптируемых мобильных роботов, обладающих высокой проходимостью, ведется во многих странах. Известны работы, в которых рассматривается конструкция и методы управления движением различных типов сферических роботов.

Особенность сферического мобильного устройства в том, что для него не существует очевидного механизма передвижения, и в тех функциональных преимуществах, которые дает ему сферическая форма. Для своего веса сферические роботы являются весьма прочными, не имеют углов, которыми они могут зацепляться за окружающие объекты, и предпочтительной ориентации. Их можно полностью герметизировать, чтобы защитить внутренние механизмы от внешних воздействий. Они обладают хорошей маневренностью и могут быть использованы в различных обстановках. Bсе это делает изучение сферических мобильных роботов интересным и полезным для таких целей как, например, выполнение разведывательных задач и сбор научных данных [1-5].

Принцип движения рассматриваемого сферического робота фактически совпадает с принципом передвижения машинки, помещенной внутрь сферы. Система будет двигаться в случае, когда машинка ездит внутри сферы.

Данный способ позволяет остановиться сфеpe в любом положении, после чего начать дви жение в другом направлении без осуществления поворота, поскольку его осуществляет находящаяся внутри машинка. Данная конструкция позволяет преодолевать значительные подъемы и препятствия, рис. 1.

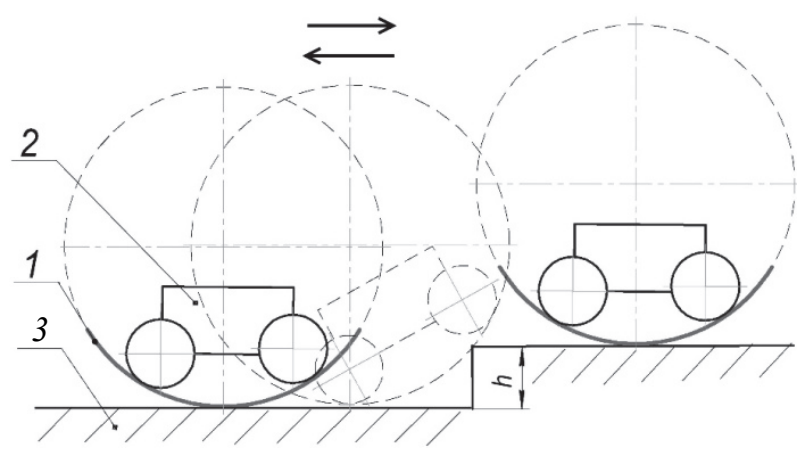

Рис. 1. Преодоление дискретных препятствий: 1 - секционный движитель; 2 - корпус транспортного средства с колесным движителем; 3 - опорная поверхность; $h$ - высота ступени

Однако данная конструкция имеет и свои недостатки. Машинка может потерять контакт с внутренней поверхностью сферы при движении, например, со склона, или же при падении со ступеньки, после чего она может перевернуться вверх колесами без возможности вернуться в исходное положение [3].

Модифицировав конструкцию и определив законы движения сферического робота, можно свести данное исследование в иную задачу: ис-

(C) Бордюгов Д. В., Фоменко С. С., Малолетов А. В., Брискин Е. С., 2021.

* Работа выполнена при финансовой поддержке Российского фонда фундаментальных исследований (проект № 1941-340013). 
следования, направленные на повышение проходимости инвалидных кресел, оснащенных дополнительными специальными устройства- ми, повышающими показатели проходимости при движении по необустроенным местам городской инфраструктуры [4].

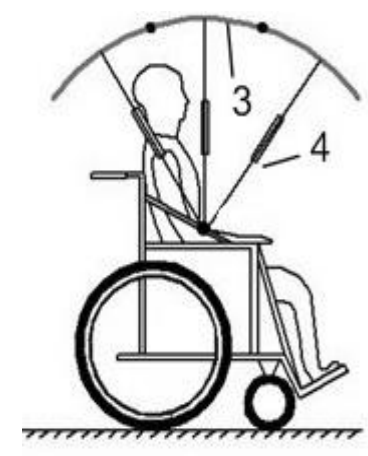

$a$
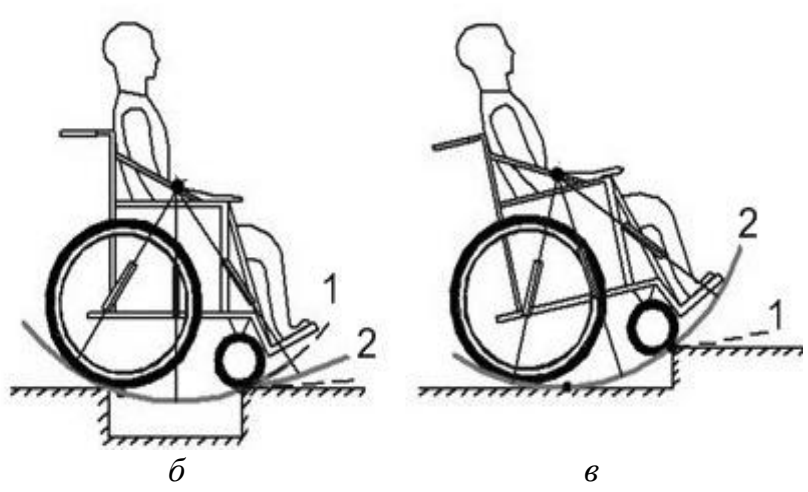

B

Рис. 2. Транспортное средство для людей с инвалидностью:

1 - корпус транспортного средства; 2 - передние колеса

Совмещение этих двух задач позволяет решить проблему управления и оптимизации параметров транспортного средства с дополнительным устройством - дополнительным секционным движителем, как элементом колесного движителя для повышения опорной и профильной проходимости с обеспечением комфортабельности движения по неровной поверхности.

Основное изменение конструкции заключается в ограничениях, накладываемых на размер контактной поверхности (рис. 3) [5, 6].

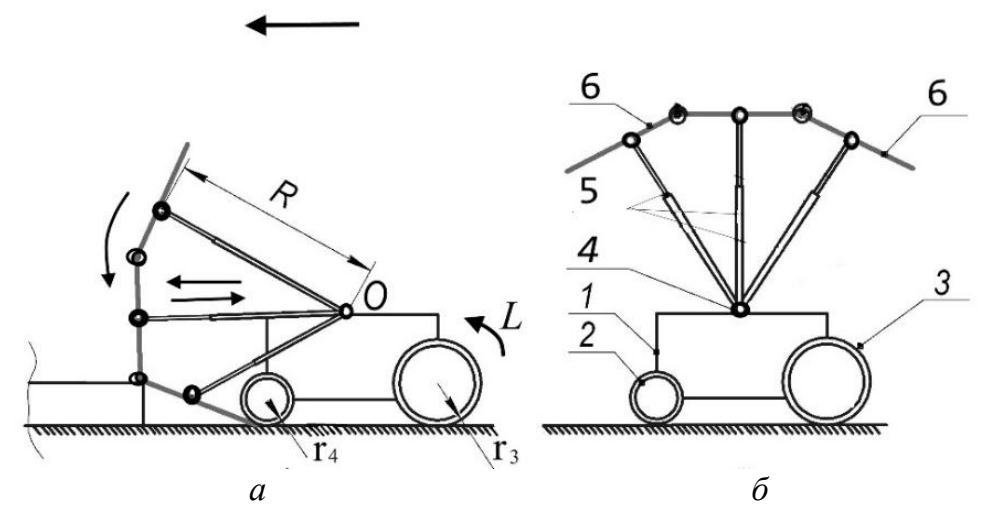

Рис. 3. Транспортное средство, оснащенное секционным движителем:

1 - корпус транспортного средства; 2 - передние колеса; 3 - задние колеса;

4 - ось вращения секционного движителя; 5 - телескопические стойки; 6 - секции движителя

Профильная проходимость, обеспечиваемая радиусом мобильного пандуса, позволяет преодолевать препятствия, такие как ступени, бордюры, выбоины на дорогах и т. д., с приемлемым углом наклона транспортного средства.

Комфортабельность перемещения обеспечивается оптимальным управлением привода транспортного средства, с учетом согласованного характера движения с дополнительным секционным движителем [6].

Рассматривается [6] динамика движения мобильного робота, оснащенного секционным движителем, обеспечивающим преодоление препятствий, в том числе, когда число степеней свободы механической системы больше числа применяемых двигателей.

Исследуемая механическая система, представленная на рис. 4 , состоит из криволинейной направляющей 1 радиусом $R$, рамы транспортного средства 2 с колесами 3,4 радиусом $r_{3}, r_{4}$. Качение тел происходит без проскальзывания друг относительно друга. Криволинейная направляющая 1 движется по поверхности 5.

Управление рассматриваемой системой осуществляется при помощи момента $M$, приложенного со стороны рамы 2 к колесу 3. 


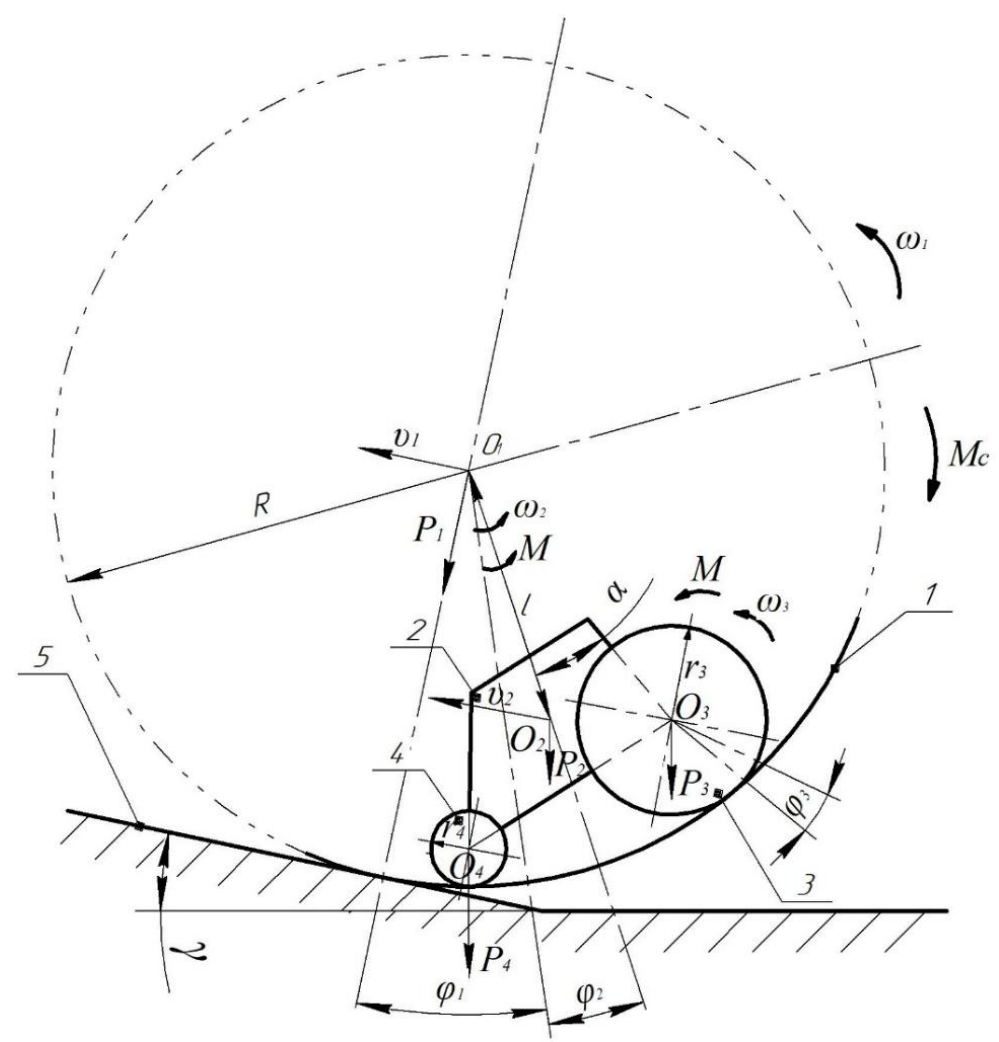

Рис. 4. Механическая система мобильного робота с секционным движителем
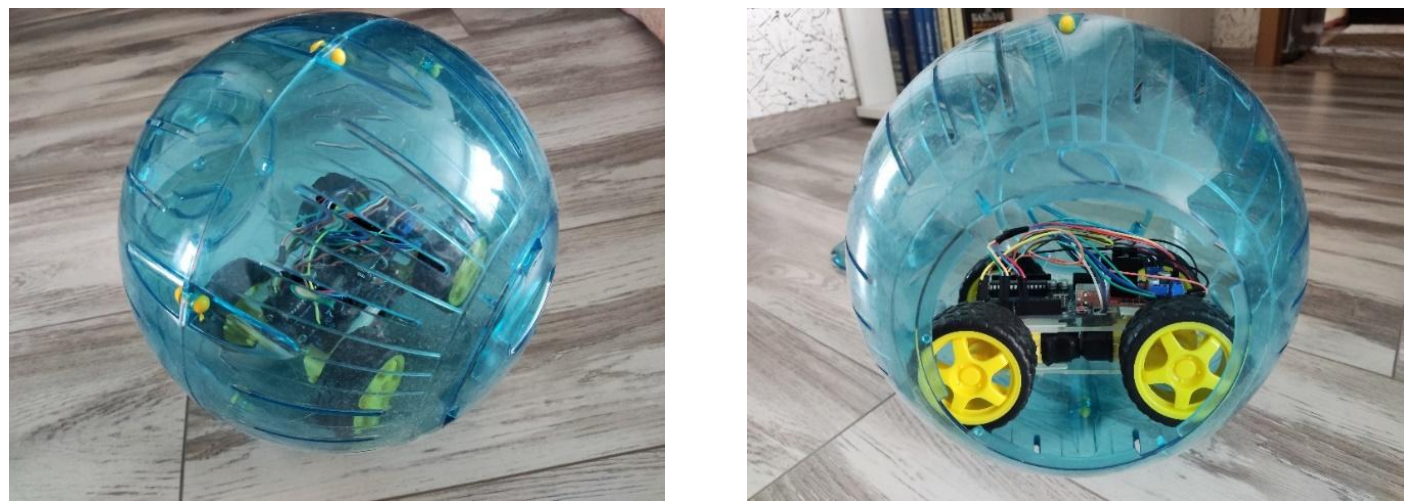

Рис. 5. Макет мобильного робота с секционным движителем

Спроектирован действующий макет мобильного робота с секционным движителем, рис. 5. Для создания опытного образца, на котором будут проводится исследования законов движения мобильного робота было решено прибегнуть к аддитивным технологиям. Мобильный робот создан на базе Arduino Uno, движение осуществляется с помощью четырех двигателей постоянного тока, которые управляются дистанционно.

\section{БИБЛИОГРАФИЧЕСКИЙ СПИСОК}

1. Halme A., Schoberg T., Wang Y. Motion control of a spherical mobile robot. In: $4^{\text {th }}$ International Workshop on Advanced Motion Control, 1996, vol. 1.
2. Rhodri H. Armour, Julian F. V. Vincent. Rolling in Natural and Robotics: A Review/ Journal of Bionic Engineering 3 (2006). 195-208.

3. Rover Company Limited. Ball-shaped Robot. St Petersburg Russia. 1996

4. П. м. 153154 РФ, МПК А61G5/00. Транспортное средство для инвалидов / Е. С. Брискин, С. С. Фоменко, Н. Г. Шаронов, В. А. Серов ; ВолгГТУ. - 2015.

5. Mikhail Svinin, Shigeyuki Hosoe. Motion Planning Algorithms for a Rolling Sphere with Limited Contact Area. IEEE Transactions on Robotics, vol. 24, no. 3, June 2008.

6. Development of Rotary Type Movers Discretely Interacting with Supporting Surface and Problems of Control Their Movement / E. Briskin, A. Maloletov, N. Sharonov [et al.] // CISM International Centre for Mechanical Sciences, Courses and Lectures (см. в книгах). - 2016. - Vol. 569. - P. 351-359. DOI 10.1007/978-3-319-33714-2_39. 
УДК 67.05

DOI: $10.35211 / 1990-5297-2021-8-255-55-57$

\title{
А. В. Ваганов, М. А. Лапиков, И. В. Волков, С. С. Шемелюнас
}

\section{УСТРОЙСТВО ДЛЯ АВТОМАТИЗИРОВАННОГО МАНИПУЛИРОВАНИЯ БИГ-БЭГАМИ*}

\author{
Волгоградский государственный технический университет \\ E-mail: usersnowman@mail.ru
}

Разработано устройство для манипулирования биг-бэгами и система автоматического управления. Представлена схема и описание устройства, а также алгоритм его работы.

Ключевые слова: биг-бэг, фасовка, сыпучий материал, автоматический.

\section{A. V. Vaganov, M. A. Lapikov, I. V. Volkov, S. S. Shemelyunas}

\section{THE DEVICE FOR AUTOMATIC MANIPULATION OF BIG-BAG}

\section{Volgograd State Technical University}

A device for manipulating big-bags and an automatic control system have been developed. The diagram and description of the device, as well as the algorithm of its operation are presented.

Keywords: big-bag, packing, bulk material, automatic.

Введение

Существует огромное количество сыпучих материалов, которые распространяются по всему миру. Одними из важнейших элементов логистики сыпучих материалов является непосредственно транспортировка и хранение. Чаще всего сыпучие материалы для дальнейшей производственной переработки хранятся и транспортируются в специальных гибких контейнерах - биг-бэгах. Фасовка биг-бэгов осуществляется либо в полуавтоматическом, либо в автоматическом режиме. Для полностью автоматического режима необходимы специализированные бигбэги, разработанные для конкретных устройств, например, наносятся метки для технического зрения или каждый биг-бэг позиционируется определенным образом при изготовлении. Фасовка обычных биг-бэгов происходит в полуавтоматическом режиме, оператор позиционирует каждый биг-бэг перед дозированием. Для повышения производительности наполнения обычных биг-бэгов было разработано устройство манипулирования биг-бэгами [1-7].

\section{Описание разработанного устройства}

На рис. 1 представлен общий вид предлагаемого устройства.

Система состоит из магазина биг бегов (мешков), состоящего из рейки 1 , цепной передачи и устройства для хранения контейнеров 2 . Устройство хранения, приводится в движение с помощью мотор-редуктора 3 по средствам цепной передачи и является неподвижной в плане регулировок по горизонтали (т. к. отвечает за базирование устройства хранения мешка).

Манипулятор состоит из направляющих 4 продольной, поперечной и вертикальной подачи, с закрепленными захватными механизма крюками 5.

Удерживающий механизм состоит из приводимых в движение направляющих, прикрепленных к рейкам 6 пневмоцилиндров 7 двухстороннего действия, шток которого шарнирно соединен с крюками 8. Патрубок 9 с элементом фиксации горловины 10 . Конвейерная лента 11 производит транспортировку заполненного и освобожденного контейнера, тем самым освобождая место для следующего мешка, позволяя сделать технологический процесс цикличным.

В начале рабочего цикла цепь посредством мотор-редуктора 3 перемещает устройство хранения мешка 2. Пара направляющих 4 подходят к месту захвата с последующим подъемом для осуществления захвата строп мешка, после захвата крюками 5 начинается процесс позиционирования горловины, патрубок 9 опускается в горловину контейнера с последующей фиксацией элементом 10. Стропы контейнера фиксируются при помощи крюков 8, приводимых в движение пневмоцилиндрами 7. По завершению процесса наполнения патрубок выходит из горловины предварительно сняв фиксацию элементом 10,

(C) Ваганов А. В., Лапиков М. А., Волков И. В., Шемелюнас С. С., 2021.

* Работа выполнена при финансовой поддержке гранта РФФИ «Аспирант» (Конкурс на лучшие проекты фундаментальных научных исследований, выполняемые молодыми учеными, обучающимися в аспирантуре) № 20-38$90290 \backslash 20$. 
пневмоцилидры 7 возвращаются в исходное положение тем самым освобождают стропы биг бе- га, мешок оказывается на конвейерной ленте 11 для последующей транспортировки.

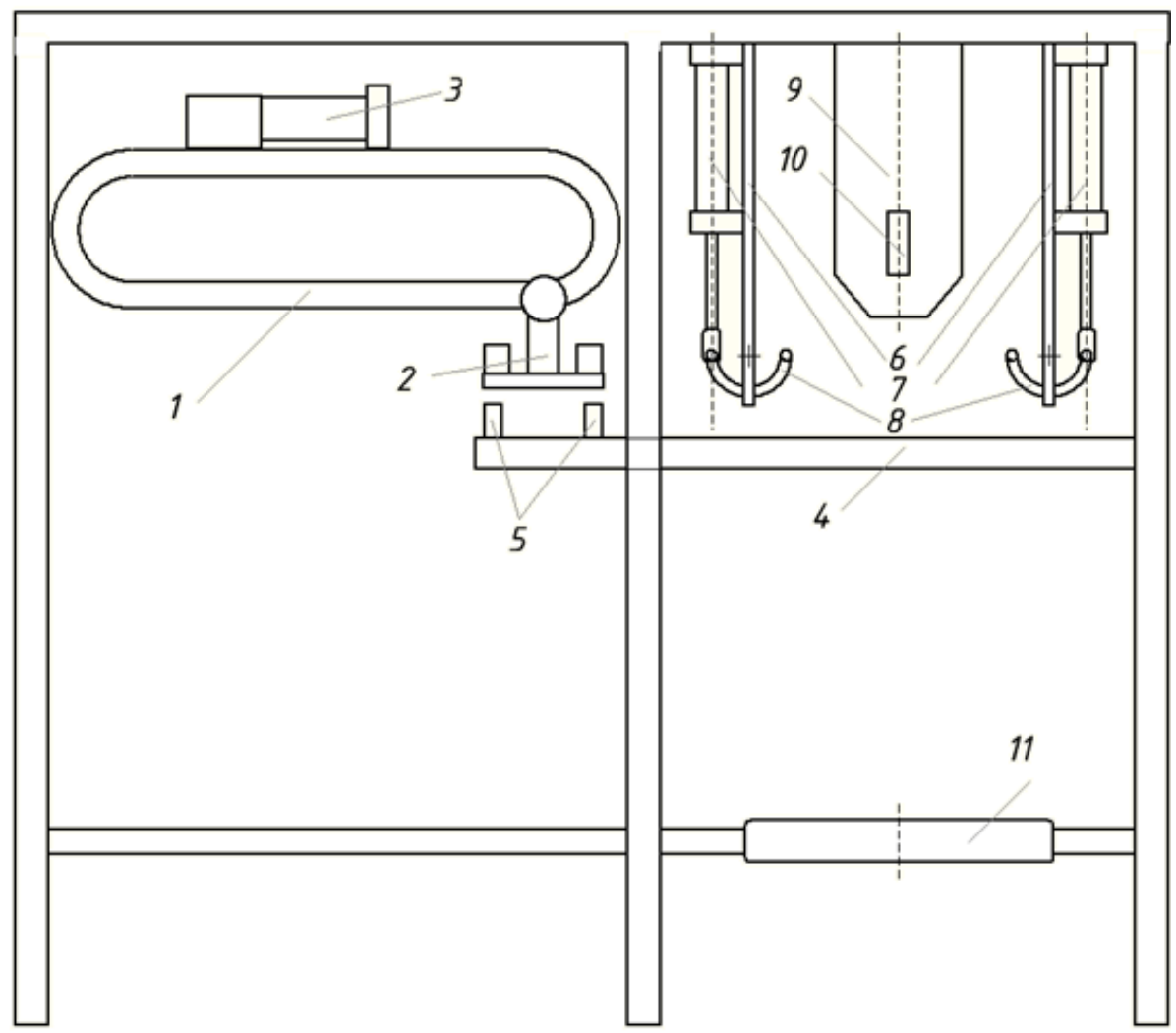

Рис. 1. Схема устройства манипулирования биг-бэгами

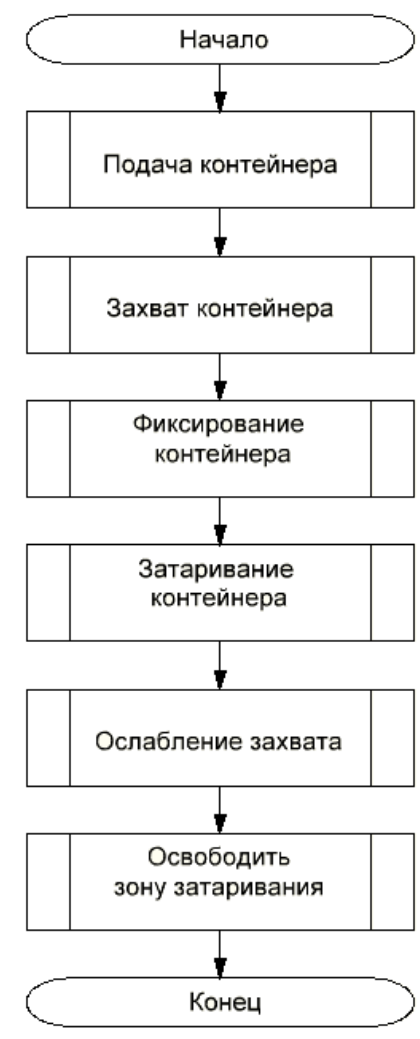

Рис. 2. Алгоритм работы устройства
Алгоритм работы устройства (рис. 2) состоит из нескольких этапов: подача контейнера, захват контейнера, фиксирование контейнера, затаривание контейнера, ослабление захвата, освобождение зоны затаривания.

Подача контейнера имеет задачу обеспечить подвод картриджа с контейнером для выполнения последующих операций. Задачей этапа захвата контейнера является захват и отвод контейнера для осуществления последующих операций. Этап фиксации является одним из самых ответственных, поскольку неправильная фиксация контейнера, не обнаруженная вовремя, может вывести из строя установку на продолжительное время. Основная задача заключается в подводе и фиксации контейнера для последующего процесса затаривания. На этапе затаривания происходит дозирование сыпучего материала в биг-бэг. Под ослаблением захвата подразумевается выполнение действий, обратных фиксированию, что в свою очередь позволяет транспортировать уже заполненный контейнер далее. Последний этап - освобождение зоны затаривания заключается в отводе заполненного контейнера из зоны затаривания, это делается 
для того, чтобы исключить случаи, когда цикл работы начинался сначала, в то время как предыдущий контейнер еще не покинул зону.

\section{Результаты и их обсуждение}

Использование предлагаемого устройства обеспечивает повышение эффективности процесса манипулирования. Эффективность устройства обуславливается тем, что смену бигбэга перед дозированием осуществляет устройство в автоматическом режиме, увеличивающее производительность и не требующее постоянного нахождения оператора возле устройства фасовки.

\section{БИБЛИОГРАФИЧЕСКИЙ СПИСОК}

1. Что такое биг-бэг мешки, и зачем они нужны [Электронный pecypc]. - Режим доступа : https://technopoliscompany.ru/chto-takoe-big-beg/ (28.06.2020)

2. Пат. 132777 РФ, МПК В65В 69/00. Устройство для автоматического затаривания биг бегов / В.В. Ефремен- ков; заявитель и патентообладатель закрытое акционерное общество "Стромизмеритель". - №2013118865/13, заявл. 23.04.2013, опубл. 27.09.2013 Бюл. № 27.

3. CN102991735B, B65B1/12, B65B1/34. Big-bag powder packaging machine / wuhan rentian packaging technology co., ltd.. - 13.05.2015.

4. CN208715521U, B65B1/32 B65B39/10. A kind of jumbo bag packaging, sack packaging all-in-one machine / Anhui Koko Is Automation Engineering Co Ltd. - 09.04.2019.

5. CN102991734A, B65B1/12, B65B1/34, B65B1/28, B65B43/54, B65B51/10. Full-automatic packaging machine / Jiangsu Tom Intelligent Equipment Co.,Ltd. - 13.08.2014.

6. Пат. 189814 Российская Федерация, МПК В65В 7/02 В65В 5/00, Устройство для автоматического манипулирования гибкими контейнерами / А. В. Ваганов, А. Е. Жупиков, А. М. Макаров; Заявитель и патентообладатель Федеральное государственное бюджетное образовательное учреждение высшего образования «Волгоградский государственный технический университет» (ВолгГТУ). - № 2018137357; заявл. 22.10.2018; опубл. 04.06.2019, Бюл. № 16.

7. Разработка и исследование автоматизированного устройства для манипулирования биг-бэгом / М. А. Лапиков, Д. С. Барабанов, И. В. Волков, А. М. Макаров // Изв. ВолгГТУ. 2020. № 8 (243). С. 65-67.

\section{Э. Ц. Галсанова ${ }^{1,2}$, А. Д. Грешилов ${ }^{1}$, Я. В. Калинин ${ }^{2}$, А. А. Яковлев ${ }^{2}$ \\ ИССЛЕДОВАНИЕ МЕТОДОВ НАГРЕВА ЗАГОТОВОК ПРИ ГОРЯЧЕЙ ЛИСТОВОЙ ШТАМПОВКЕ}

${ }^{1}$ Восточно-Сибирский государственный университет технологий и управления

${ }^{2}$ Волгоградский государственный технический университет

E-mail: erjena_g@mail.ru

Представлен обзор новых теоретических исследований в области методов нагрева горячей листовой штамповки особопрочных металлических сплавов и постановка задач исследования.

Ключевые слова: методы нагрева, горячая штамповка, листовая штамповка, нагревательная установка, нагревание.

\section{E. Ts. Galsanova ${ }^{1,2}$, A. D. Greshilov' ${ }^{1}$ Ya. V. Kalinin' ${ }^{2}$, A. A. Yakovlev ${ }^{2}$ \\ INVESTIGATION OF METHODS OF HEATING WORKPIECES DURING HOT SHEET STAMPING}

${ }^{1}$ East Siberia State University of Technology and Management ${ }^{2}$ Volgograd State Technical University

An overview of new theoretical studies in the field of methods of heating hot sheet stamping of extra-strong metal alloys and the formulation of research tasks is presented

Keywords: temperature stresses, hot stamping, sheet stamping, heating unit, heating.

\section{Введение}

Для повышения качества изделий совершенствуют технологию листовой горячей штамповки, стремясь максимально приближать форму и размеры заготовки к форме и размерам готовой детали [1]. При этом необходимо минимизировать влияние упругой отдачи или пружинения листовых заготовок из высокопрочных материалов при помощи подбора метода и оборудования для нагрева, позволяющие получить как можно более равномерный нагрев в необходимой зоне заготовки. Это бы обеспечивало равномерное распределение напряжений по площади заготовки.

(C) Галсанова Э. Ц., Грешилов А. Д., Калинин Я. В., Яковлев А. А., 2021. 


\section{Исследования в области технологии горячей листовой штамповки}

Технология листовой горячей штамповки включает следующие этапы: определение размеров заготовки, выбор исходного материала, составление карты раскроя, при горячей штамповке выбор метода и оборудования для нагрева и т. д. Порядок следования таких этапов условен, так как выбор метода и оборудования для нагрева будет влиять на размеры заготовки, соответственно на составление карты раскроя. Так, например, при использовании электроконтактного метода предусматривают место для крепления контактов, которые впоследствии вырезают. В исследованиях [2] было экспериментально определено влияние технологии нагрева на упругую отдачу. Падение температуры материала во время ручного переноса из печи в фильеру и падения температуры фланца во время формовки значительно увеличивает упругую отдачу до $3 \%$ и требует создания более совершенного метода горячей штамповки с контролем температуры.

Технологию листовой горячей штамповки можно автоматизировать путем создания системы автоматизированного подбора оптимального выбора метода и оборудования для нагрева для заданных размеров и материала заготовки. Для создания такой САПР требуется исследование процессов [1], происходящих при штамповке, что значительно повысит эффективность штамповки. Промышленное изготовление деталей из листовых материалов имеет большие объемы, соответственно их производство влияет на себестоимость конечного продукта.

Для того, чтобы создать автоматизированную среду для выбора функциональных и проектных схем и расчета параметров нагревательных устройств в горячей листовой штамповке необходимо провести обзор исследований по методам и материалам для горячей штамповки.

\section{Материалы заготовок, условия их штампуемости}

Для авто- и авиапромышленности используют высокопрочные листовые металлические материалы, такие как сталь и цветные металлы. Проблемы формуемости листовой автомобильной стали (AHSS) были описаны в статье [3] в связи с получением нового поколения особопрочных материалов для деталей кузова и уменьшением их массы. Структура данных сплавов после горячей штамповки обуславли- вает высокую прочность, но низкую пластичность. Разрабатывая стали нового поколения Mn-TRIP исследования показали, что необходимо решить вопрос влияния температур на пластичность.

В обзорной статье [4] приведены сверхвысокопрочные борсодержащие сплавы марки стали $22 \mathrm{MnB} 5$, как наиболее часто используемые. Однако такие сплавы имеют такой недостаток, как образование окалины при взаимодействии с воздухом при аустенизации. Для его предотвращения используют защитные покрытия, например, металлические или масляные, имеющие также трибологические свойства. Исследования показали важность влияния температуры и скоростей деформации в специально изготовленных деталях на геометрические и механические свойства детали. А именно, что формуемость листового металла при повышенных температурах может быть оценена путем применения соответствующего критерия разрушения, который может быть разработан как функция деформации, скорости деформации, температуры и изменения микроструктуры.

В работах $[5,6]$ рассмотрены исследования в области горячей штамповки различных металлических листовых сплавов: алюминиевых, магниевых, титановых. Было установлено, что повышение температуры штамповки положительно влияет на качество получаемых изделий. Для улучшения формообразующих характеристик, расширения пределов штамповки, минимизации усилий деформации, требуемой точности детали и их характеристик, штамповка должна проводиться в зависимости от свойств материала и температурного режима, включая нагрев и охлаждение. Однако необходимо более тщательное изучение влияния следующих аспектов: совершенствование конструкции формовочного и нагревательного оборудования, обеспечение и распределение температуры по площади заготовки, трибологические условия.

В статье [7] описана модель для прогнозирования кривых напряжения-деформации при различных температурах и скоростях деформации, позволяющая оптимизировать первоначальную форму заготовки на основе анализа изменения температуры, скорости деформации и траектории нагружения с помощью вязкопластических уравнений в областях разрушения алюминиевого сплава AA7075 в процессе горячей штамповки с применением программ КЭ, Pamstamp и Autoform. 
Исследования механической анизатропии алюминиевого сплава АА7В04 описаны в работе [8]. Для характеристики анизотропии алюминиевой пластины AА7B04 пластина была разделена на несколько слоев по направлению толщины. И в каждом слое расчет изгибающего момента производился соответственно на основе критерия текучести фон Мизеса, Хилла 48 и Yld2004-18p. После упругой отдачи была рассчитана кривизна нейтральной поверхности, и профиль нейтральной поверхности был построен методом смешивания поверхностей Безье. Для проверки метода прогнозирования было проведено моделирование методом конечных элементов и эксперимент по изгибу. Результаты показывают, что точность прогнозов этого метода была более точной, чем у модели изотропии.

Работы по моделированию и прогнозирования величины пружинения титанового сплава OT4-1 описаны в статье [9]. Разработан математический подход на основе эмпирических данных, позволяющий на этапе проектирования штамповой оснастки и разработки технологического процесса штамповки учесть пружинение заготовки и добиться стабильного получения заданных размеров и формы детали.

В работе [10] описывается проблема точного определения упругой отдачи листового титанового сплава TA15 в зависимости от температуры и скорости деформации, а также релаксации напряжений во время закалки в штампе. Предполагается, что равномерное нагревание значительно снижает упругую отдачу. Моделирование процесса производится с помощью системы Gleeble.

\section{Методы нагрева}

Исследования [11] показали, что технология нагрева заготовки оказывает большое влияние на свойства детали, продолжительность и эффективность горячей штамповки. Равномерная температура и короткое время нагрева являются основными требованиями к нагревательной установке.

В настоящее время в основном используются электроконтактный, индукционный, газовый методы и нагрев в печах. Нагрев в печах в настоящее время считается бесперспективным для усовершенствования, так как имеет множество недостатков, основным является инвестиционные затраты, хотя имеет и технологические проблемы, такие как образование газонасыщенного слоя и значительное время разогрева.
Более привлекательными методами для совершенствования можно считать электроконтактный [12] и индукционный $[13,14]$. При использовании данных методов образуется неравномерность распределения температуры по площади заготовки, обусловленную зонами контакта с электродами при электроконтактном методе и геометрией индуктора при индукционном, что вызывает появление упругой отдачи в готовой детали.

Исследования [13] показали, что процесс индукционного нагрева-штамповки высокопрочных листов из легированной бором стали с заданными температурными режимами может обеспечивать распределение температуры стального листа по площади заготовки в соответствии с различными требованиями к прочности. Достижение повышения прочностных характеристик готового изделия обеспечивает использование магнитных колец в необходимых областях заготовки с коэффициентом разности прочности на разрыв в 3,5 раза и коэффициентом разности удлинения более, чем в 2,2 раза.

В работах $[15,16]$ было проведено исследование газовой листовой штамповки с односторонним и двусторонним нагревом для листовых заготовок из стали толщиной до 2 мм и из цветных металлов толщиной до 5 мм. Листовая заготовка с одной или двух сторон подвергается воздействию высокотемпературного газа и интенсивно нагревается. Данный метод показывает высокую надежность, но имеет недостаток: необходимо разбирать конструкцию для установки и съема заготовки. Теоретическое расхождение величины температуры заготовки при различных значениях времени нагрева и давления топливной смеси при штамповке с экспериментальными данными составляет около $12 \ldots 15 \%$. В настоящее время чаще при газовой листовой штамповке используют электроконтактный или индукционный методы нагрева $[17,18]$.

\section{Выводы}

В данной статье представлен обзор последних исследований в области горячей штамповки, подтверждающий высокую актуальность данной темы. Анализ этих исследований показал, что процесс горячей листовой штамповки в настоящее время широко исследуется у нас и за рубежом, а также выявил необходимость дальнейшего изучения методов нагрева и влияния распределения температур на пластические свойства особопрочных листовых сплавов. 
Проведенные исследования показали, как получить высокую точность формы горячештампованных деталей с минимальным пружинением. Однако, в связи с отсутствием общих основ решения данной проблемы - изготовление деталей с заданными свойствами - необходимо провести дополнительные исследования, направленные на изучение влияния различных процедур фазового преобразования на геометрические и механические свойства детали.

Кроме того, на основе полученных данных, появляется возможность создания САПР, основным назначением которой является выбор физического принципа действия для нагрева излучением, конструктивной схемы нагревательной установки, а также определение оптимальных конструктивных решений и режимов работы в зависимости от параметров заготовок, условий технологического процесса нагрева и дальнейших действий с заготовкой.

\section{БИБЛИОГРАФИЧЕСКИЙ СПИСОК}

1. Sajan, M., Amirthalingam, M., Chakkingal U. A novel method for the spring-back analysis of a hot stamping steel//Journal of Materials Research and Technology. - 2021. Vol. 11. - Pp. 227-234.

2. Nakagawa, Y., Mori, Ki. \& Maeno, T. Springback-free mechanism in hot stamping of ultra-high-strength steel parts and deformation behaviour and quenchability for thin sheet. The International Journal of Advanced Manufacturing Technology, 2018. -Vol. 95. - Pp. 459-467.

3. Yi, H. L., Sun, L., Xiong, X. C. Challenges in the formability of the next generation of automotive steel. Materials Science and Technology // Materials science and technology, 2018. - Vol. 34. - N 9. - Pp. 1112-1117.

4. Karbasian, H., Tekkaya, A.E. A review on hot stamping// Journal of Materials Processing Technology, 2010. Vol. 210. - Is. 15. - Pp. 2103-2118.

5. Neugebauer, R., Altan, T., Geiger, M., Kleiner, M., Sterzing, A. Sheet metal forming at elevated temperatures//CIRP Annals, 2006. - Vol. 55. - Is.2. - Pp. 793-816.

6. Doege E., Kurz G., Doege E. Development of a formulation to describe the work softening behaviour of magnesium sheets for heated deep drawing processes // CIRP Annals, 2001. - Vol.50. - Is.1. - Pp.177-180.

7. Zhu M., Lim Yi. C., Liu Xi., Cai Zh., Dhawan S., Gao $H$., Politis D. J. Numerical forming limit prediction for the optimisation of initial blank shape in hot stamping of AA7075 // International Journal of Lightweight Materials and Manufacture, 2021. - Vol.4. - Is.3. - Pp. 269-280.
8. Liu C., Li M., Yue T. Springback prediction method for double-curved workpiece considering plate anisotropy in multi-point forming // Journal of Mechanical Science and Technology, 2021. - Vol. 35. - Is.6. - Pp. 2623 - 2636.

9. Разработка математической модели профилирования пуансона и матрицы для гибки листовых титановых сплавов / Ц. А. Батуев, А. Д. Грешилов, Ю. Л. Шурыгин, Э. Ц. Галсанова // Материалы VII Международной научной конференции «Проблемы механики современных машин», 25 - 30 июня 2018. - Т.3. - 20-24 стр.

10. Lechler, J. Grundlegende Untersuchungen zur Beschreibung und Modellierung des Werkstoffverhaltens von presshärtbaren Bor-Manganstählen. Dr.-Ing. Dissertation, LFT, University of Erlangen-Nuremberg. - 2009.

11. Chen, Y., Han, G., Li,Y., Li,Z., Lin,Z. Time-dependent springback prediction with stress relaxation effect for nonisothermal hot stamping of titanium alloy sheets// International Journal of Advanced Manufacturing Technology, 2021. Vol.115. - Is.1-2. - Pp. 637-653.

12. Kocar $O$, Livatyalı $H$. Investigation on the mechanical properties of press-hardened boron steel sheets using the conductive heating technique // Proceedings of the Institution of Mechanical Engineers, Part L: Journal of Materials: Design and Applications, 2020. - N234(8). - Pp.1084-1098.

13. Bao Li, Liu W.J., Wang Bo, Li H., You X., Zhou Q., Liu M., Gao Sh. Experimental investigation on partition controllable induction heating-hot stamping process of highstrength boron alloyed steel plates with designable temperature patterns // Journal of Materials Research and Technology, 2020. - Vol.9. - Is.6. - Pp. 13963-13976.

14. Mori K., Maki S., Tanaka Y. Warm and Hot Stamping of Ultra High Tensile Strength Steel Sheets Using Resistance Heating // CIRP Annals, 2005. - Vol.54. - Is.1. - Pp. 209-212.

15. Боташев, А. Ю. Экспериментальные исследования газовой штамповки с двухсторонним нагревом заготовки / А. Ю. Боташев, Н. У. Бисилов, Р. С. Малсугенов // Заготовительные производства в машиностроении. 2014 №1. - C. 17-19.

16. Боташев, А. Ю. Разработка и исследование устройства для газовой штамповки с односторонним нагревом заготовки / А. Ю. Боташев, Н. У. Бисилов, Р. С. Малсугенов // Известия высших учебных заведений. Машиностроение, 2014. - № 7. - С. 28-33.

17. Пат. 878392 РФ, МПК В21D 26/12. Устройство для импульсной листовой штамповки с нагревом заготовок / Чачин В. Н., Сманцер А. Г., Бачурин Ю. Д., Рубан А. П. ; заявитель и патентообладатель Физико-технический университет Белорусской ССР. - № 2879893/27, заявл. 04.02.1980.; опубл. 20.12.2013 Бюл. № 35 .

18. Falaleev, A.P., Meshkov, V.V., Vetrogon, A.A., Shymchenko, A.V. Evolution of mechanical properties of boron/manganese 22MnB5 steel under magnetic pulse influences// IOP Conference Series: Materials Science and Engineering, 2016. - Vol. 110(1) - Is. 1. - N.012107. 
УДК 654.071.3

DOI: 10.35211/1990-5297-2021-8-255-61-64

\section{М. Г. Горбунов, В. Г. Барабанов \\ МОДЕРНИЗАЦИЯ УСТРОЙСТВА УПРАВЛЕНИЯ РОЛЬГАНГАМИ ДЛЯ ТРАНСПОРТИРОВКИ ТРУБНОЙ ЗАГОТОВКИ}

Волгоградский государственный технический университет

E-mail: app@vstu.ru

Разработана система управления электроприводом рольгангов. Разработаны принципиальные электрические схемы и схемы подключения. Даны характеристики всех входящих в систему устройств. Описаны основные преимущества использования частотного регулирования. Описан алгоритм работы управляющей программы.

Ключевые слова: система управления $(\mathrm{CУ})$, частотное регулирование, частотный преобразователь, ПЛК, станция удаленных входов/выходов.

M. G. Gorbunov, V. G. Barabanov

\section{MODERNIZATION OF CONTROL UNIT OF ROLLERS FOR TRANSPORTATION OF PIPE BILLETS}

\section{Volgograd State Technical University}

A control system for the electric drive of roller tables has been developed. Basic electrical and connection diagrams have been developed. The characteristics of all devices included in the system are given. The main advantages of using frequency regulation are described. The algorithm of the control program is described in detail.

Keywords: control system (CS), frequency regulation, frequency converter, PLC, remote I / O station.

В качестве объекта управления в работе рассматривается асинхронный двигатель АРМ 53-12. Вся рольганговая линия условно разделена на секции, начиная с секции № 69. На рольганговой линии имеются устройства («выбрасыватель») в количестве 3 шт. С первых двух заготовки поступают на линию, а с последней - забираются с нее. На рис. 1 показан начальный участок линии рольганг, включающий 69, 70 секции и первый «выбрасыватель». Всего секций - 14. На секциях установлено по 14-20 двигателей.

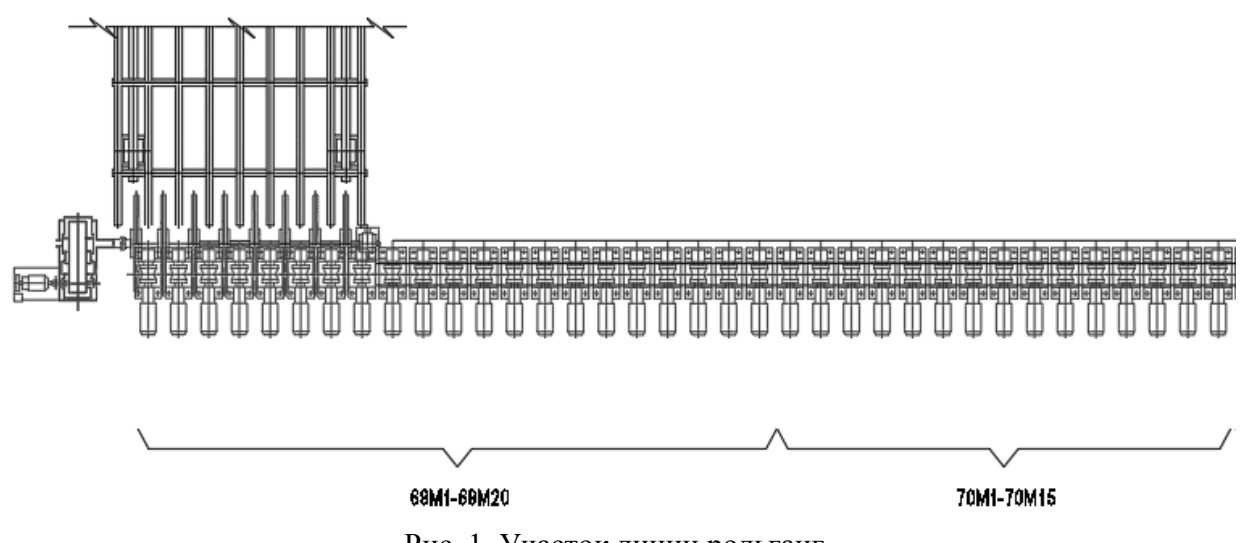

Рис. 1. Участок линии рольганг

На пульте установлена ключ-бирка для сборки схемы в рабочее положение, ключи (переключатели 3-позиционного) управления секциями (назад-0-вперед). Использование магнитных пускателей позволяет управлять асинхронными электродвигателями путем непосредственного подключения двигателя к сети переменного тока. Для управления используется ре- версивный контактор. Для аварийного останова всех секций предусмотрен «ключ-бирка». Данный ключ размыкает все контакторы.

Модернизации СУ сводится к использованию промышленной сети с использованием частотного управления двигателями вместо применяемого в описанной установке релейного управления. Для управления преобразователя

(C) Горбунов М. Г., Барабанов В. Г., 2021. 
частоты (ПЧ) по сети Profibus будет использоваться ПЛК. В роли интерфейса будет выступать терминал оператора. Для сборки цепи используется станция удаленных входов/выходов, которая необходима для аварийного отключения всех двигателей от сигнала двухпозицион- ного переключателя «ключ-бирка». Также необходим датчик, по сигналу которого будет производиться торможение последней 82 секции, для предотвращения биений заготовок об конечный упор. Структурная схема СУ представлена на рис. 2.

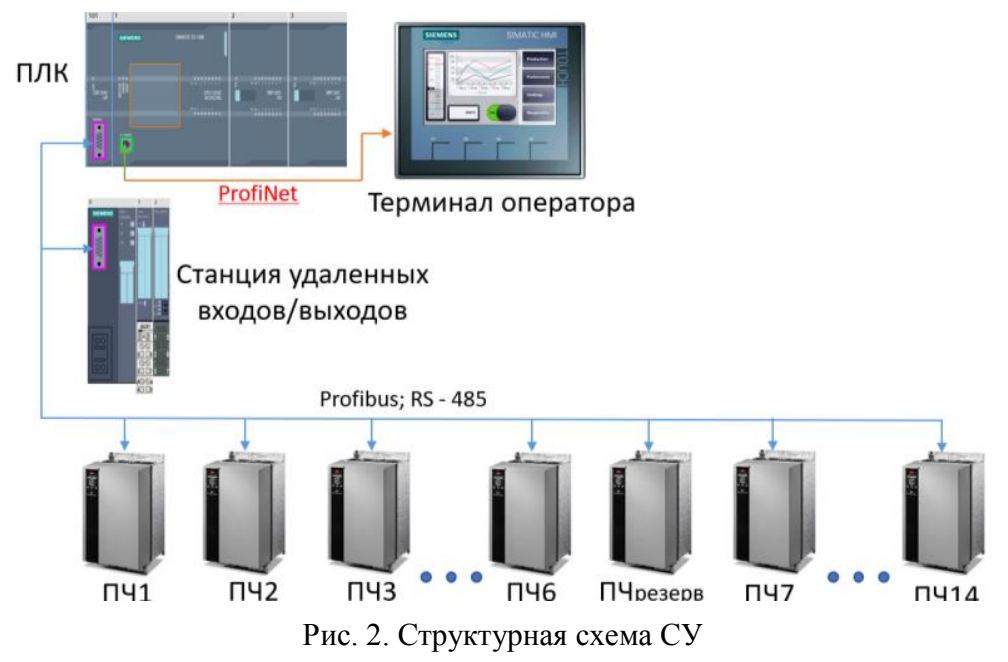

В данной СУ используются:

- ПЛК. Выбран контроллер средней мощности - SIMATIC S7-1200 с CPU 1212C, а также два модуля на 16 DI каждый. Для работы с сетью Profibus DP необходим коммуника- ционный модуль - СМ 1243 DP [1];

- частотный преобразователь. На основе расчета тока и мощности двигателей каждой секции выбраны ПЧ: VLT Automation Drive FC302 в количестве 15 шт [2];

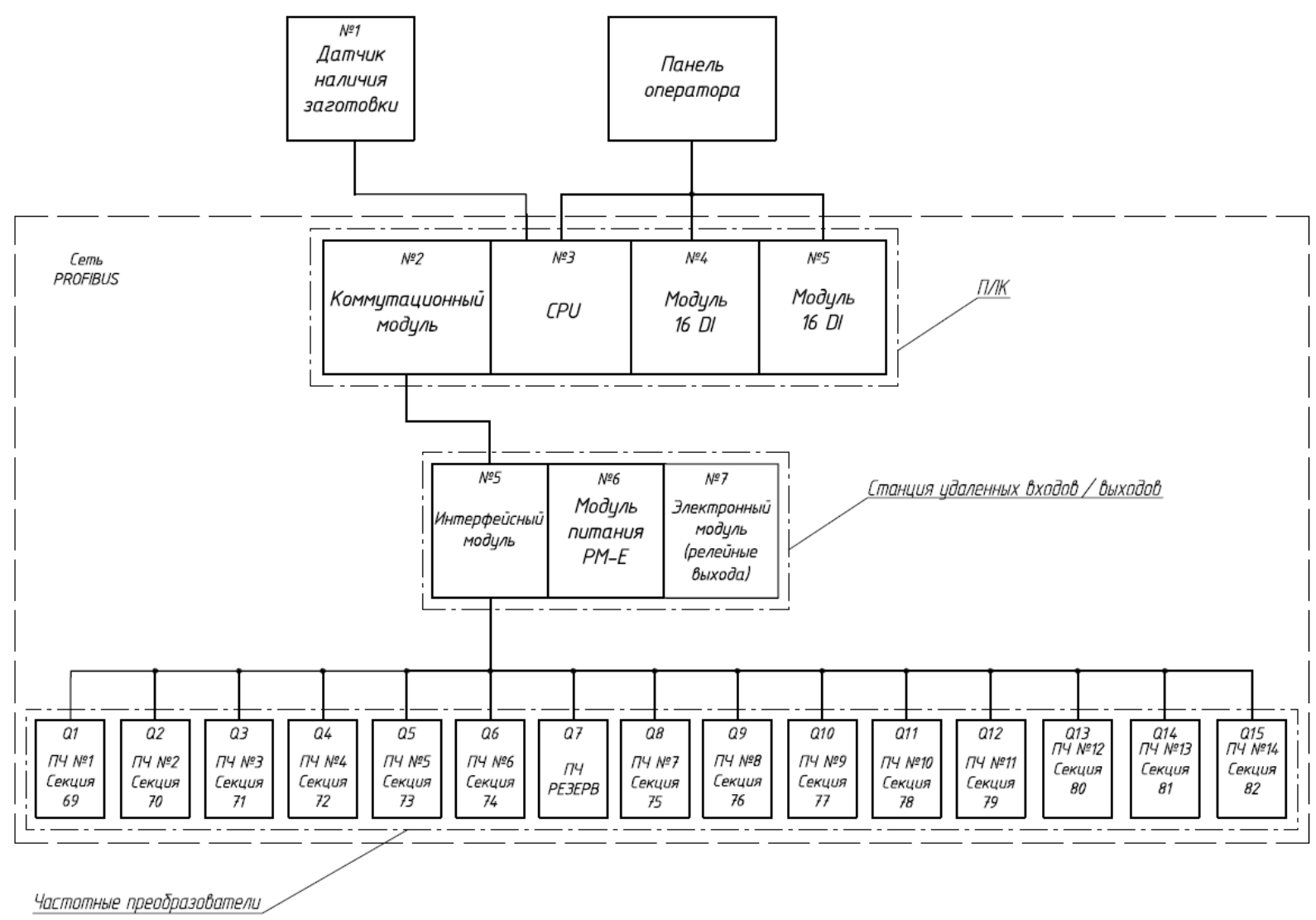

Рис. 3. Подробная структурная схема СУ 
- терминал оператора - KTP400 Basic;

- станция удаленных входов/выходов ЕТ $200 S$, содержащая: интерфейсный модуль, модуль питания и модуль на два релейных выхода, один из которых будет «собирать» цепи основных 14 ПЧ, а второй ПЧ резерва в случае его надобности [3];

- индуктивный датчик наличия заготовки ВБИ-Ф80-40У-2131.
Более подробная структурная схема СУ представлена на рис. 3 .

Панель оператора представлена на рис. 4. Она включает в себя:

- KTP400 Basic - терминал оператора

- SA1 - ключ-бирка

- SA2 - переключатель режимов

- SA3- SA16 - переключатель направления вращения двигателей

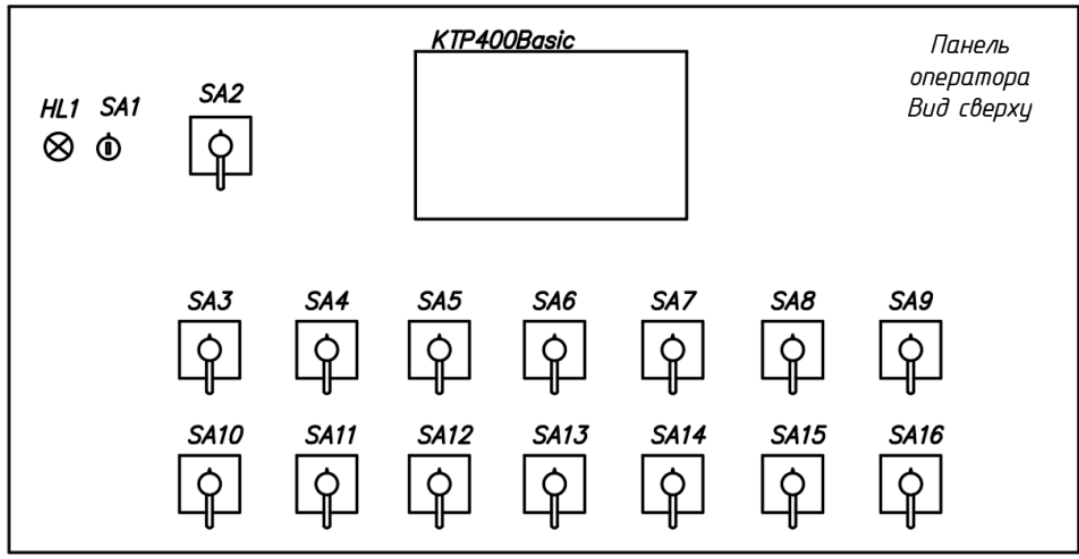

Рис. 4. Панель оператора

СУ имеет два режима работы: автоматический и ручной. В автоматическом режиме привод работает по следующей управляющей программе:

- если заготовку кладут на секцию № 69, то включаются секции с № 62 по № 82, работают в течении 60 с., потом отключаются. Если 60 с не истекли, а заготовку положили на секцию № 69, то время начинается отчитываться заново;

- если заготовку кладут на секцию № 73, то включаются секции с № 73 по № 82, работают в течении 40 с., потом отключаются. Если 40 с. не истекли, а заготовку положили на секцию № 73, то время начинается отчитываться заново;

- секция № 82 останавливается по наличию заготовки, когда заготовку заберет выбрасыватель, секция запуститься.

В ручном режиме управление производится с помощью трехпозиционных переключателей. Для работы в ручном режиме необходимо установить задание преобразователям частоты.

Управляющая программа написана в среде
Simatic - Tia Portal [4]. Первоначально необходим HardWare каталог, т.е. топология сети (рис. 5). После необходимо назначить адреса и тип телеграммы каждого участнику сети. Выбрана телеграмма типа РPO6, содержащая 4 слова. Все РРО определяются для циклической передачи данных - для передачи данных процесса и параметров от главного устройства подчиненному и обратно. PLC высылает данные управления процессом, и преобразователь частоты возвращает PPO такой же длины с данными о состоянии процесса.

Также были определены параметры для программирования частотных преобразователей, учитывая торможение на последней секции.

В этой же среде создан интерфейс терминала (рис. 6). Программа написана на языке LAD (релейная логика). Он содержит окно главного меню, окна для работы с каждой секцией, а также окна аварии. Имеется функционал ввода в работу резервного ПЧ, на случай выхода из строя любого основного. 


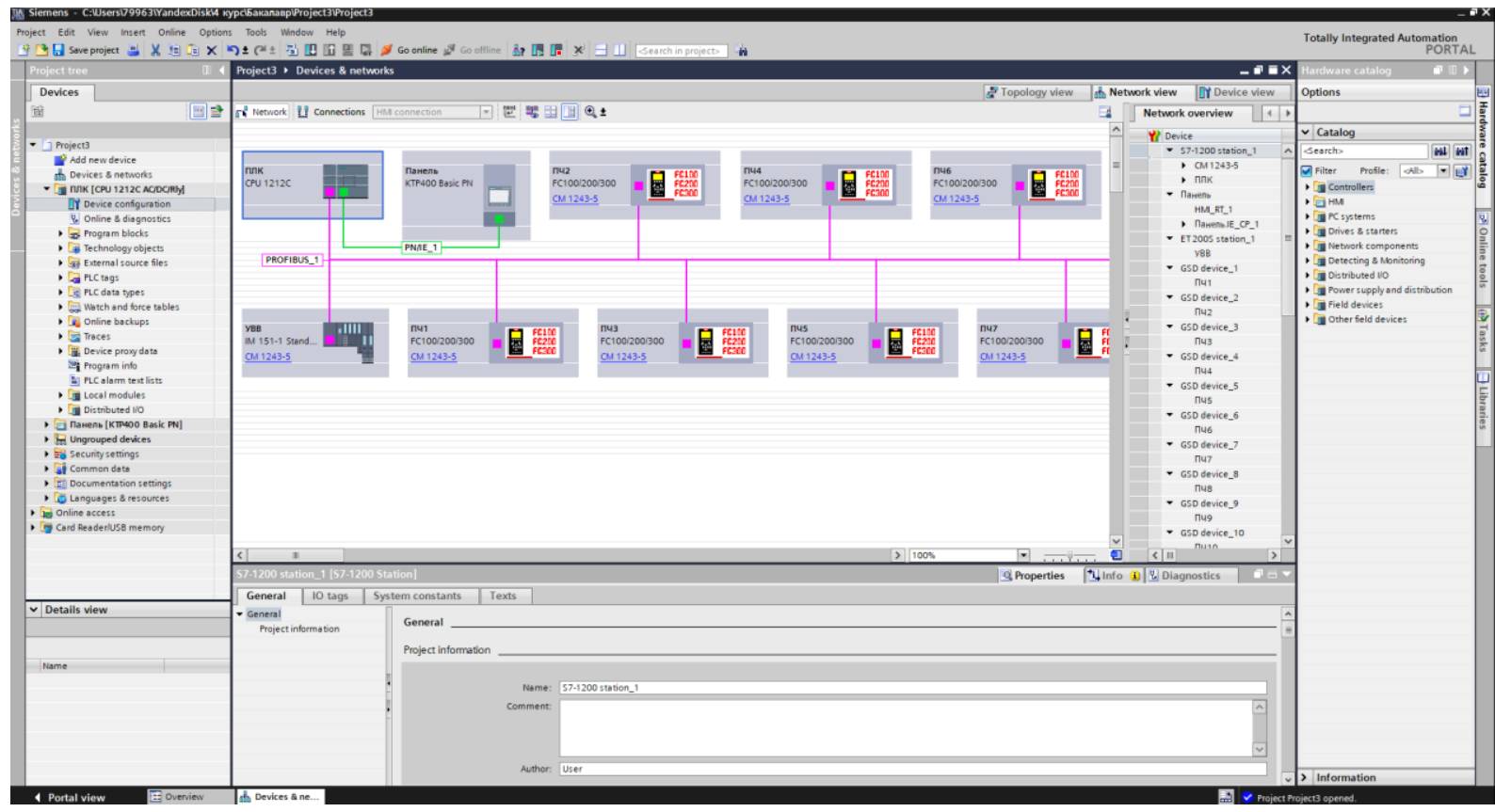

Рис. 5. Топология сети

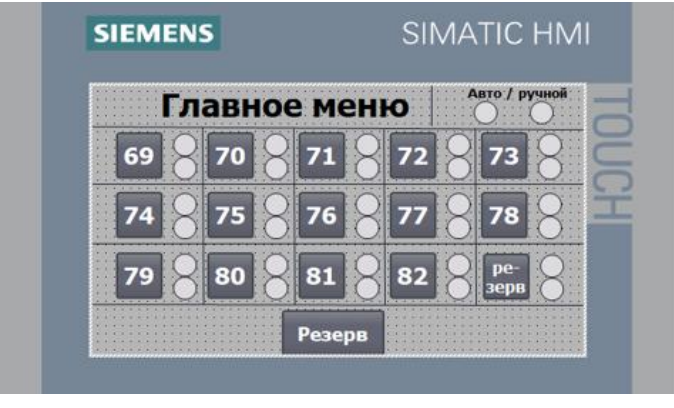

$a$

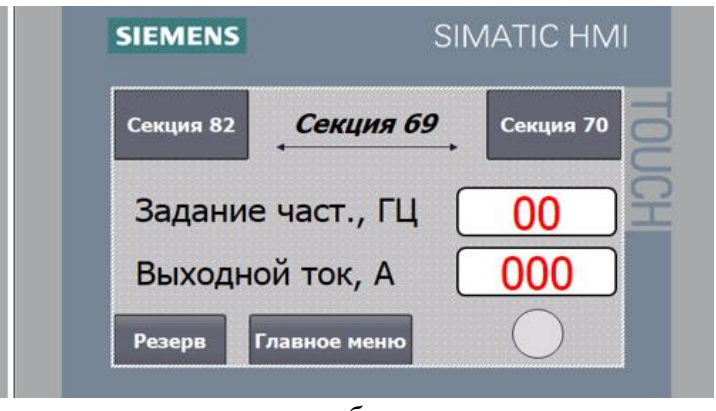

$\sigma$

Рис. 6. Интерфейс терминала оператора: $a$ - окно главного меню; $\sigma$ - рабочее окно 69 секции

В результате модернизации устройства управления рольгангами получены следующие результаты:

- использование ПЧ позволяет устанавливать различные частоты питающего напряжения (скорость транспортировки), а также имеется возможность позиционирования трубных заготовок за счет применения динамического торможения;

- управление происходит по одной шине RS-485 (отсутствует необходимость в большом числе проводов);

- работа привода в автоматическом режиме не требует постоянного присутствия оператора для отключения линии;

- СУ позволяет дистанционно диагностировать неисправности в работе приводов;

- работа двигателей на низкой частоте (в пределах 15-18 Гц) позволит заметно снизить электропотребление (снижение электропотребления на $50 \%$ );

- введение резервного ПЧ позволяет увеличить надежность системы.

\section{БИБЛИОГРАФИЧЕСКИЙ СПИСОК}

1. Программируемые контроллеры S7-1200. Системное руководство. - 2009. Режим доступа: https://spt.ru/uploads/pdfs/siemens-plk-simatic-s7-1200-rukovodstvopo-ekspluatatsii-rus.pdf (дата обращения 07.03.2021).

2. Характеристики частотного преобразователя VLT AutomationDrive FC 301, FC 302. - Режим доступа: https://drives.ru/produkciya/vlt-automationdrive-fc302/danfoss-vlt-automationdrive-fc-302-90-kvt-134f0292/ (дата обращения 25.02.2021).

3. Станция ET $200 \mathrm{~S}$. Технические характеристики. 2014. - Режим доступа: http://www.ste.ru/siemens/pdf/rus/ ET200S_2014.pdf (дата обращения 06.03.2021).

4. STEP 7 (TIA Portal) и STEP 7 Safety в TIA Portal. Руководство по программированию S7-1200/S7-1500: офиц. сайт. - 2015. - Режим доступа: http://tia-portal.ru/manual/ (дата обращения 21.03.2021). 


\title{
К. А. Драпак, Е. Г. Крылов, А. М. Макаров, Н. В. Козловцева ПЕРСПЕКТИВЫ РАЗВИТИЯ ПРОЕКТОВ ПО ПРОИЗВОДСТВУ СПГ В РОССИИ
}

\author{
Волгоградский государственный технический университет \\ E-mail: app@vstu.ru
}

В статье рассмотрены основные проекты по производству сжиженного природного газа (СПГ) в России с учетом их мощностей, крупнейшие регазификационные терминалы Европы, а также соотношение роста спроса и предложений по СПГ в мире. Дан сравнительный анализ установленной мощности на предприятиях по производству СПГ и ее влияние на увеличение прибыли. Описана оценка эффективности заводов по производству СПГ с учетом индекса Нельсона.

Ключевые слова: СПГ, индекс Нельсона, индекс Мещерина, газоперерабатывающий завод, регазификационный терминал.

\section{K. A. Drapak, E. G. Krylov, A. M. Makarov, N. V. Kozlovtseva THE PROSPECTS FOR THE DEVELOPMENT OF LNG PRODUCTION PROJECTS IN RUSSIA}

\section{Volgograd State Technical University}

The article considers the main LNG production projects in Russia, taking into account their capacities, the largest regasification terminals in Europe, as well as the ratio of the growth of demand and supply for LNG in the world. A comparative analysis of the installed capacity at the LNG production facilities and its impact on the increase in profits is given. An assessment of the efficiency of LNG plants is described, taking into account the Nelson index.

Keywords: LNG, Nelson index, Meshcherin index, gas processing plant, regasification terminal.

Природный газ по сравнению с нефтепродуктами является экологически чистым полезным ископаемым. По данным мировых аналитических агентств спрос на природный газ будет устойчиво расти [1]. Постановлением Правительства Российской Федерации от 16 марта 2021 г. № 640 была утверждена долгосрочная программа развития производства сжиженного природного газа (СПГ) в РФ, в которой выполнен анализ основных тенденций развития мирового энергопотребления, описаны меры поддержания проектов, связанных с производством СПГ, различные виды применяемых технологий, прогнозы развития рынка газа в России [2].

СПГ-терминал представляет собой специальный регазификационный комплекс, состоящий из причала, сливной эстакады, резервуаров для хранения, испарительной системы, установок обработки газов испарения из резервуаров и узла учета [3]. Эти терминалы располагаются рядом с заводами по сжижению и хранению газа с дальнейшим экспортом продукции.

Проекты по производству сжиженного природного газа в России по большей части сосредоточены в арктических регионах нашей страны. В соответствии с [2] разработан график ввода в эксплуатацию заводов по производству СПГ в ближайшие 6 лет. Это стало возможным за счет реализации ряда мер поддержки газовой отрасли, обеспечивших:

- рост конкурентоспособности российского СПГ на мировом рынке и рост доли российского СПГ с 5 до 8 процентов;

- развитие технологического потенциала на базе разработки отечественной технологии сжижения газа «Арктический каскад»;

- развитие транспортной инфраструктуры Обской губы и Северного морского пути.

На базе постоянных потребителей СПГ создаются новые центры потребления газа, формируются благоприятные условия для развития производств автономной газификации. Глобальное внедрение СПГ будет способствовать решению ряда стратегических задач промышленного развития нашей страны: позволит решить ряд экологических проблем, связанных с добычей энергетических ресурсов, повысить качество жизни населения и энергоэффективность коммунального хозяйства, оптимизировать топливно-энергетические ресурсы с учетом затрат на покупку СПГ.

Наиболее перспективными группами месторождений для реализации проектов по производству СПГ являются регионы, относящиеся к Арктическому шлейфу, где расположены крупнейшие месторождения газа (Южно-Там-

(C) Драпак К. А., Крылов Е. Г., Макаров А. М., Козловцева Н. В., 2021. 
бейские, Средневилюйское, Мастахское, Толонское, Тымтайдахское, Хапчагайское, ЮжноКринское, Северо-Обское, Солетско-Ханавейское, Геофизическое, Трехбугорное, ЗападноАнобарское).
На рис. 1 представлена диаграмма основных проектов производства СПГ в РФ, на которой зеленым цветом указаны годы реализации проектов, синим цветом - установленная мощность млн. тон в год.

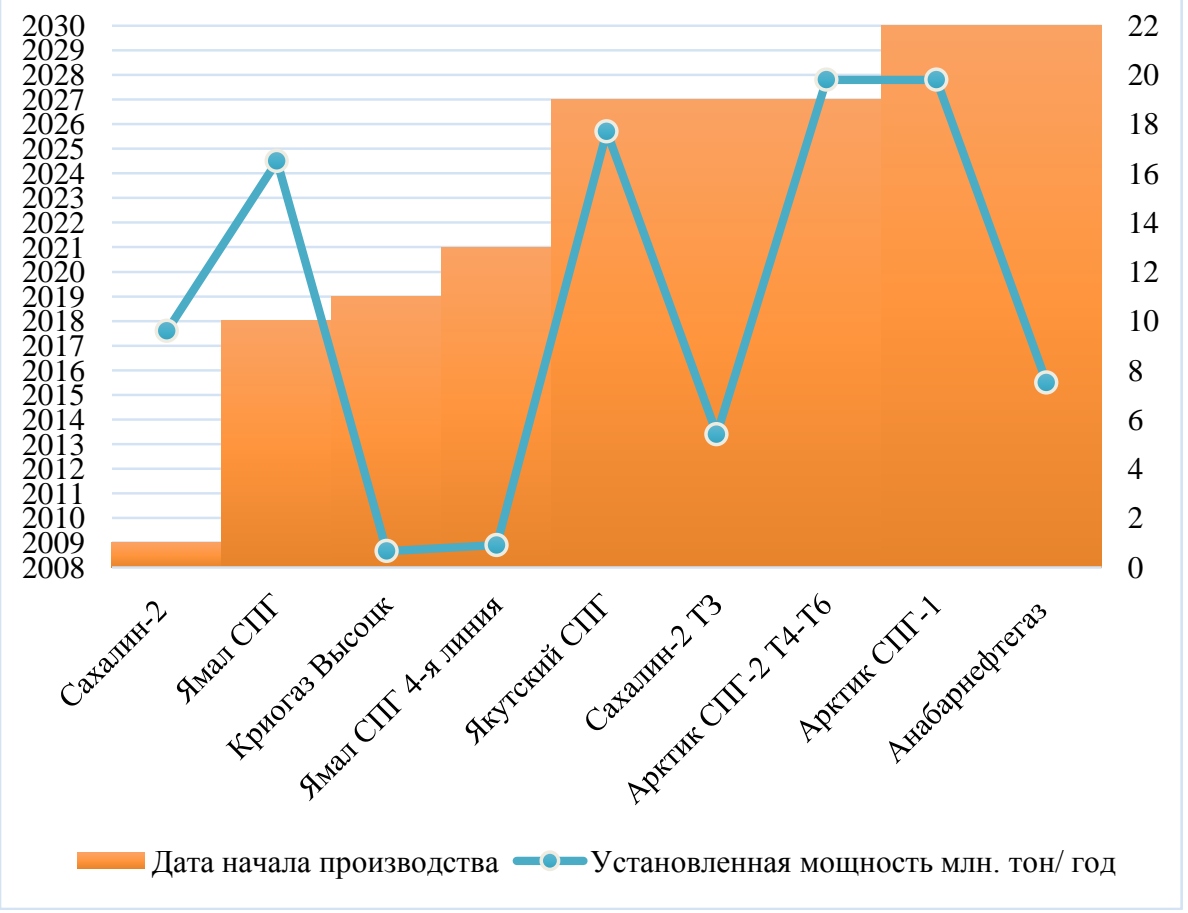

Рис. 1. Проекты производства СПГ в России

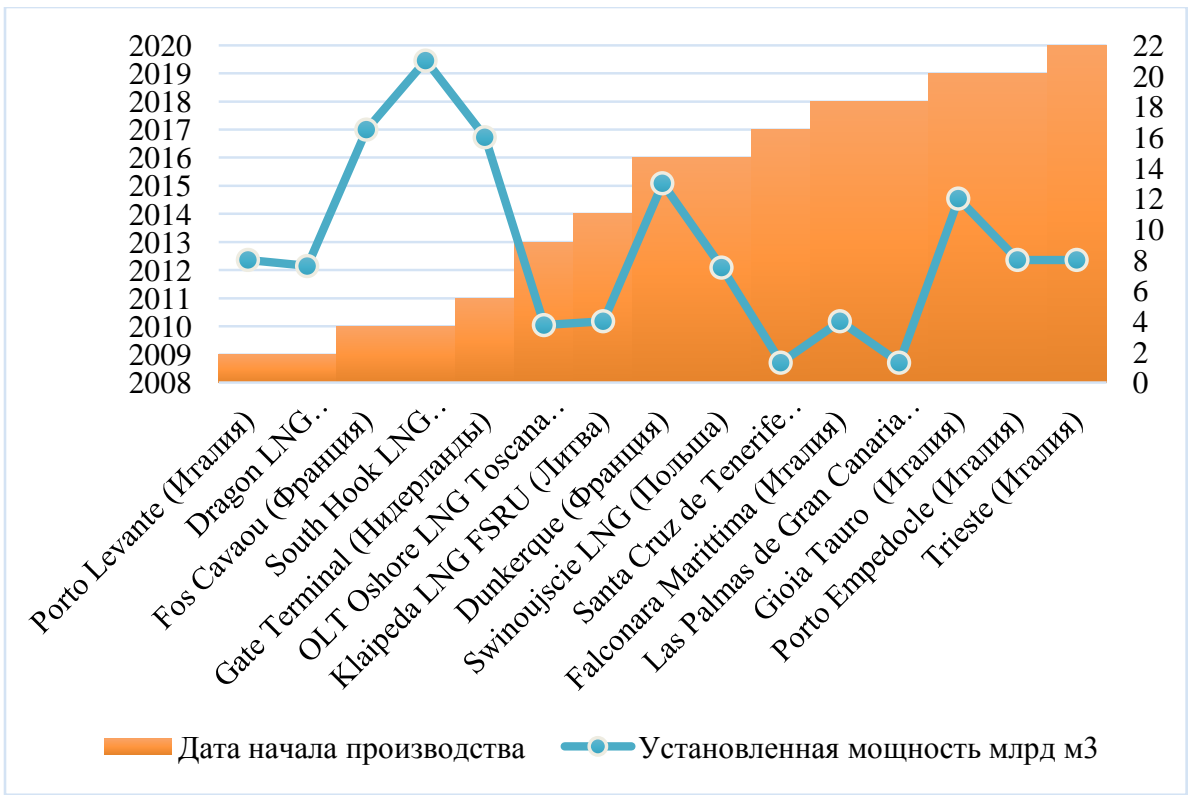

Рис. 2. Крупнейшие СПГ-терминалы в странах Евросоюза

В странах Евросоюза в соответствии с новой энергетической стратегией EC1, предписывающей полное избавление от потребления уг- ля к 2030 г, также ведется строительство СПГтерминалов. На рис. 2 представлена диаграмма основных проектов производства СПГ в стра- 
нах Евросоюза, на которой зеленым цветом указаны годы реализации проектов, синим цветом - установленная мощность млрд м $^{3}$.

Анализ мирового рынка энергоресурсов позволяет сделать вывод, что долгосрочное превышение спроса над предложением позволит наращивать объемы поставок при дефиците
СПГ в условиях устойчивого роста цены на газ. Соотношение роста спроса и предложений по СПГ в мире показано на рис. 3, на котором зеленым цветом указан рост мощностей по производству СПГ (предложений), синим цветом рост спроса на СПГ не в евро.

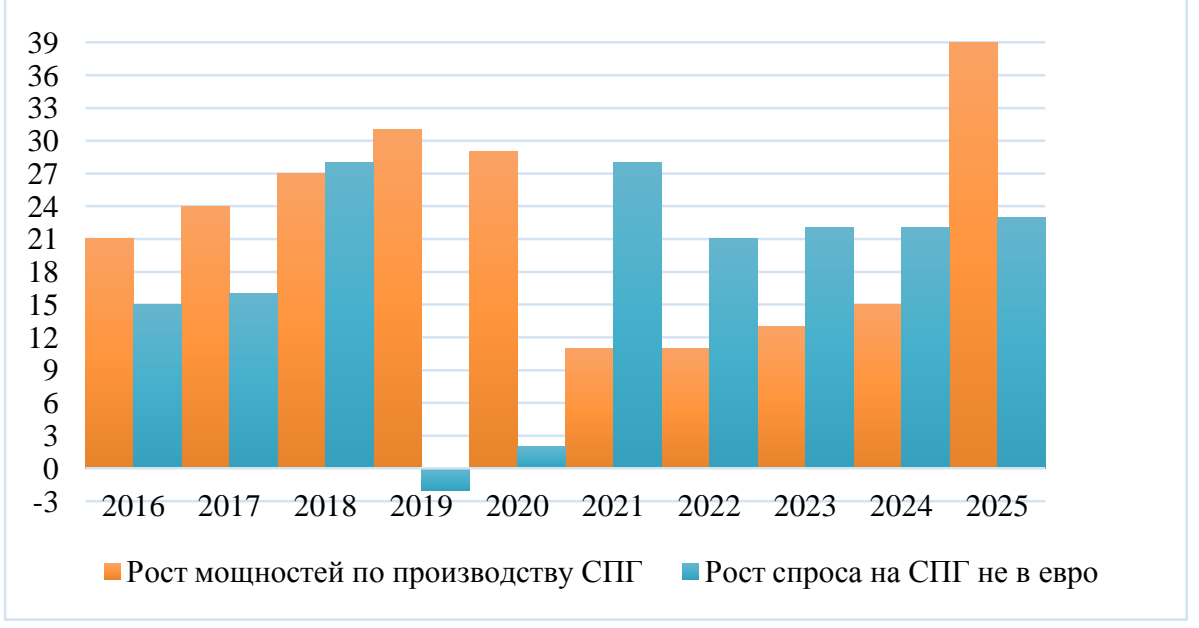

Рис. 3. Соотношение роста спроса и роста предложений по СПГ в мире, млн. тонн в год

Для успешной реализации проектов по производству СПГ необходима комплексная количественная оценка эффективности проектирования и внедрения сложного автоматизированного оборудования. Основу такой оценки может составить индекс Нельсона, который представляет собой отношение удельных затрат на сооружение установки любого процесса нефтеперерабатывающего завода (НПЗ) к удельным затратам на установку первичной переработки нефти и отражает технологическую сложность производства.

Индекс Нельсона каждой единице оборудования присваивает коэффициент на основе стоимости оборудования с точки зрения наиболее простого процесса получения продукта.

$$
N C L=\sum_{i=1}^{N} F_{i} \cdot\left(\frac{C_{i}}{C_{C D U}}\right)=\frac{V_{L N G}}{V_{L N G}+\sum_{i} V_{i}}+\frac{\sum_{i} P_{i} / P_{L N G} \cdot V_{i}}{V_{L N G}}+\frac{K c p}{K} \cdot 0,01+\frac{C \cdot T C C}{P_{L N G}}-\frac{L}{100 \cdot T C P},
$$

где $F_{i}$ - фактор сложности завода; $C_{i}$ - единица мощности завода; $C_{C D U}$ - емкость блока установки перегонки (резервуара); $V_{L N G}-$ объем производства СПГ; $P$ - стоимость продукции; $V$ - объем газа $\left(i=\mathrm{CO}_{2}, \mathrm{CH}_{4}\right.$, редкие газы и др.); $Т C P$ - удельные транспортные затраты $1400 \mathrm{~m}^{3}$ газа на 100 км; TCC - удельные затраты на утилизацию 1 тонны $\mathrm{CO}_{2} ; K$ и $K c p-$ коэффициенты запаса мощностей по хранению.

Абсолютное значение индекса Нельсона варьируется в пределах от 1 до 20 и характеризует следующее: чем индекс больше, тем сложнее производство, шире ассортимент выпускаемой продукции, выше его конкурен- тоспособность и относительная стоимость. На итоговое значение индекса основное влияние оказывают такие параметры как: коэффициент сложности каждой единицы основного производственного оборудования; коэффициент, учитывающий рост капиталовложений для строительства установки; коэффициент потери производительности; стоимость капитальных вложений в строительство (млн. руб.); производительность установки (т/час); потери производительности по выходному продукту. Например, НПЗ в США являются самыми сложными в мире, обладая значением индекса от 10 до 12 пунктов. Для российских НПЗ значение индекса Нельсона в среднем составляет 4-5. 
Для производств СПГ индекс Нельсона требует модификации в соответствии со структурой газоперерабатывающего завода. В работе [4] была предпринята попытка уточнения данного индекса, однако зависимости, полно и однозначно учитывающей особенности технологических процессов переработки газа, не было выявлено. В частности, требуют уточнения такие параметры как: данные по утечкам и стоимости оборудования, коэффициент сложности установки или процесса переработки газа; расходы компании для проектирования или покупки установок по производству и переработки СПГ. Для крупнотоннажного производства необходимо знать фактические потери газа на каждой установке. Нахождение решения данной задачи позволит дать объективную количест- венную оценку эффективности проектирования и эксплуатации СПГ-терминалов.

\section{БИБЛИОГРАФИЧЕСКИЙ СПИСОК}

1. EIA: Annual Energy Outlook 2021 (with projections to 2050) - eng [Электронный ресурс]: официальный сайт. Режим доступа: https://nangs.org/analytics/eia-annualenergy-outlook-2021-with-projections-to-2050-eng-pdf-pptx (дата обращения: 20.05.2021).

2. Долгосрочная программа развития производства сжиженного природного газа в РФ: утв. распоряжением Правительства РФ от 16.03.2021 г. №640-р. - Режим доступа: http://publication.pravo.gov.ru/Document/View/ 0001202 (дата обращения 20.05.2021).

3. Оценка уровня надежности защиты регазификационного терминала / К. А. Драпак, Т. С. Кадыгрова, Е. Г. Крылов, А. В. Капитанов // Известия ВолгГТУ : научный журнал № 3 (250) / ВолгГТУ. - Волгоград, 2021. - (Серия «Прогрессивные технологии в машиностроении»). - С. 54-56.

4. Мещерин, И. В. Индекс Мещерина. Индекс сложности для заводов и установок по производству СПГ/ И. В. Мещерин // Neftegaz.RU. - 2019. - № 4. - С. 56-59.

УДК 621.7 .068

DOI: $10.35211 / 1990-5297-2021-8-255-68-72$

\title{
А. В. Забродин, Ю. С. Багайсков
}

\section{РАЗРАБОТКА КОНСТРУКЦИИ РЫБОЗАЩИТНОГО УСТРОЙСТВА}

\author{
Волжский политехнический институт (филиал) \\ Волгоградского государственного технического университета \\ E-mail: bagaiskov@post.volpi.ru
}

Водозаборное сооружение является функциональным элементом системы водоснабжения, но должно быть одновременно и рыбозащитным объектом. К устройствам современных средств защиты рыб на водозаборах предъявляются следующие основные требования: предотвращение попадания и гибели молоди и личинок рыб, предупреждение травмирования молоди и личинок рыб, отвод защищенных рыб от водозабора, надежность функционирования при конкретных условиях и средствах. По принципу работы наиболее эффективной является активная схема, с принудительным формированием гидравлической структуры потока. Предлагается конструкция устройства универсального комбинированного типа с использованием в качестве потокоформирующего элемента струегенератора, создающего реактивное гидравлическое движение, предназначенное для защиты рыб и молоди с размером тела менее 15 мм.

Ключевые слова: водозабор, устройство, рыбозащита, конструкция, струегенератор, комбинирование.

\section{A. Zabrodin, Yu. Bagaiskov}

\section{DEVELOPMENT OF A FICH PROTECTION DEVICE DESIGN}

\section{Volzhsky Polytechnic Institute (branch) Volgograd State Technical University}

The water intake structure is a functional element of the water supply system, but it must also be a fish protection object. The following basic requirements are imposed on the devices of modern fish protection devices at water intakes: prevention of ingress and death of young fish and larvae, prevention of injury to young fish and larvae, removal of protected fish from water intake, reliability of operation under specific conditions and means. According to the principle of operation, the most effective is the active scheme, with the forced formation of the hydraulic flow structure. The design of a universal combined type device with the use of a jet generator as a flow-forming element that creates a reactive hydraulic movement designed to protect fish and juveniles with a body size of less than 15 $\mathrm{mm}$ is proposed.

Keywords: water intake, device, fish protection, construction, jet generator, combination.

() Забродин А. В., Багайсков Ю. С., 2021. 
Водозаборное сооружение является функциональным элементом технологической системы водоснабжения, должно бесперебойно отбирать и подавать воду, но при этом должно быть и природоохранным сооружением, являясь одновременно и рыбозащитным объектом [1]. Данное требование утверждено в природоохранном законодательстве Российской Федерации. Следовательно, рыбозащитные устройства должны являться обязательным элементом водозаборного сооружения.

К устройствам современных средств защиты рыб на водозаборах предъявляются следующие основные требования: предотвращение попадания и гибели молоди и личинок рыб; предупреждение травмирования молоди и личинок рыб; отвод защищенных рыб от водозабора; надежность функционирования при конкретных условиях и средствах $[1,2]$.

Рыбозащитные устройства подразделяются на несколько групп: механические, гидравлические и физиологические. Наиболее распространенными являются механические устройства

Для предотвращения гибели рыб используется много конструкций рыбозащитных устройств, отличающихся вариантами компоновки в составе водозаборного сооружения, принципом работы, водопропускной способностью и эксплуатационными характеристиками. На действующих водозаборных системах применяют устройства различных конструкций с эффективностью рыбозащиты от 45 до $75 \%$ для рыб с длиной тела до 40 мм и от 70 до $90 \%$ для рыб с длиной тела более 40 мм [3]. На рис. 1 приведена сравнительная диаграмма эффективности различных конструкций рыбозашитных устройств.

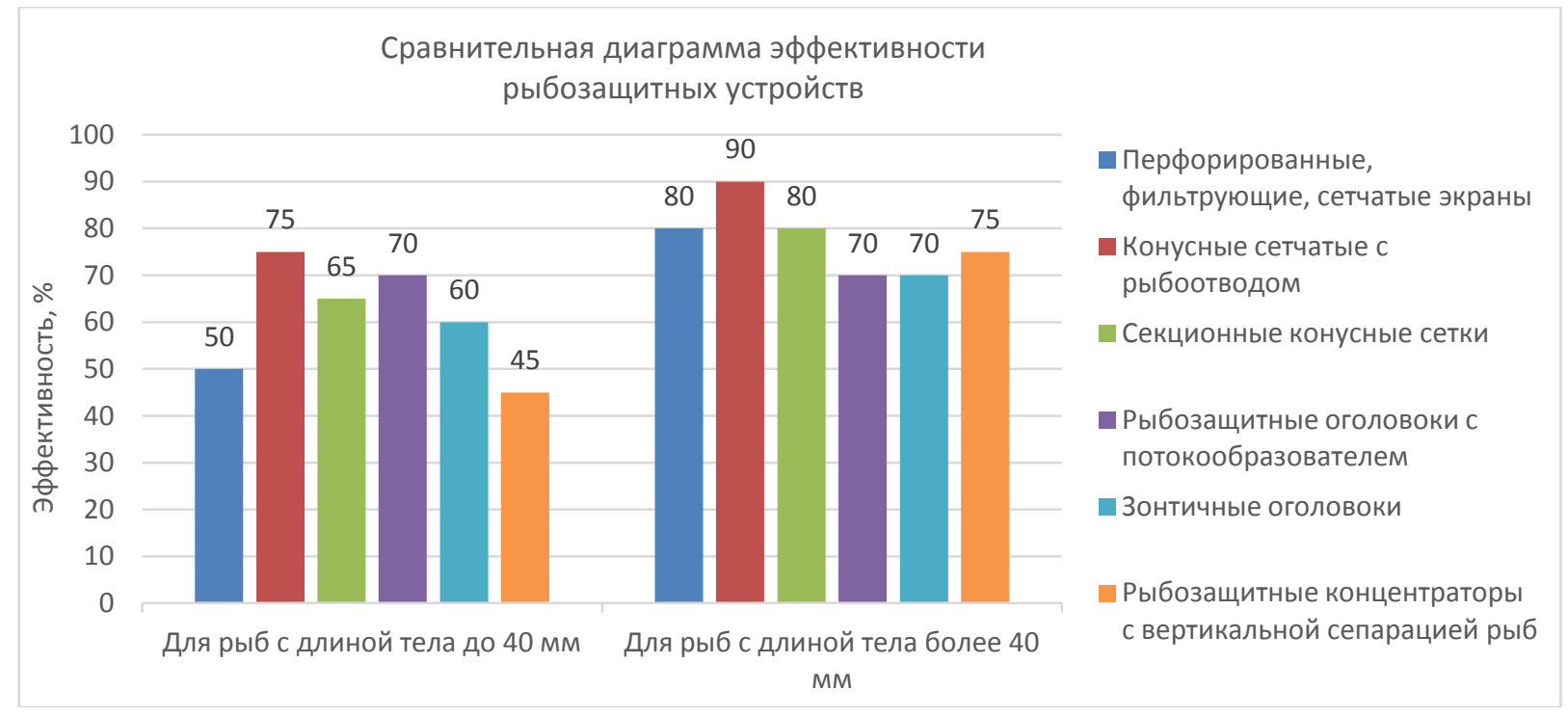

Рис. 1. Сравнительная диаграмма эффективности различных конструкций рыбозащитных устройств

Анализ условий работы водозаборного сооружения показал, что основным объектом защиты является ранняя, пассивно скатывающаяся молодь рыб, не способная сопротивляться потоку и самостоятельно уходить от источника опасности. Чтобы предотвратить ее гибель, недостаточно разработать устройства, только отпугивающего или ограждающего назначения. Необходимо обеспечить такие условия на уровне гидравлических процессов, при которых эксплуатация устройства не оказывала бы на молодь существенного влияния, и она могла бы беспрепятственно, не контактируя с защитными элементами, пассивно скатываться от водозаборных приемников.
Для реализации названных требований в конструкцию рыбозащитных устройств должны входить минимум три основных функциональных элемента: входной потокоформирующий, рабочий защитный и выходной рыбоотводящий.

Эти конструктивные элементы рыбозащитного устройства последовательно осуществляют соответствующий комплекс функций [4].

Доминирующую роль в структуре рыбозащитного устройства должен выполнять потокоформирующий элемент - основной функциональный элемент рыбозащитного устройства, предназначенный для реоградиентной коррекции потока воды путем формирования его 
гидравлической структуры, обеспечивающей бесконтактную защиту молоди.

Для определения оптимального вида такого устройства рассмотрим их особенности и возможности. Так как потокоформирующие элементы ответственны за организацию необходимой для защиты рыб гидравлической структуры транзитного потока, то и анализируют их в зависимости от способа их воздействия на водоток. Эти элементы принято разделять на две группы [5]:

- пассивные, формирующие необходимую для защиты рыб гидравлическую структуру только при обтекании их транзитным потоком;

- активные, принудительно формирующие гидравлическую структуру втекающего в устройство потока. Для этого они используют поступающую к ним дополнительную энергию (напорную воду, воздух, механизмы).

С точки зрения практичности и универсальности, активные потокоформирующие элементы более предпочтительны. Наиболее эффективный и универсальный тип среди них, это устройства, подающие в поток водяные струи струегенераторы, по следующим причинам [5]:

- во-первых, струегенераторы, действуя на поток водяными струями наиболее естественно, чем остальные, влияют на формирование его гидравлической структуры, необходимой для защиты рыб;

- во-вторых, большинство водозаборов оборудованы насосами, то есть они уже имеют источник напорной воды, что надо для работы струегенератора;

Видно, что наиболее универсальным потокоформирующим элементом является струегенератор, формирующий транзитное течение в благоприятном гидравлическом режиме.

При выборе типа рабочего органа его одними из важнейших характеристик являются взаимоисключающие пропускная и рыбозащитная способности. В идеале обе эти способности желательно иметь максимальными.

Рабочие органы с точки зрения активности их воздействия на рыб, разделяют на три основные группы:

- пассивные - глухие экраны, которые являются для рыб только препятствием, отгораживающим рыбообитаемую зону от источника опасности;

- пассивно-принудительные - водопроницаемые экраны, омываемые транзитным течением, которое формирует вдоль них транзит- ную зону опасности, стимулирующую выход рыб из этой зоны;

- активные, которые оказывают непосредственное влияние на физиологию, поведение и плавательные способности рыб, и своим воздействием заставляющие рыб самостоятельно или принудительно покинуть опасную зону действия водозабора.

Наиболее универсальными и практичными являются активные рабочие органы, которые гарантированно оказывают на рыб необходимое воздействие.

По характеру проявления реакции выхода рыб из опасной зоны активные рабочие органы также разделяют на следующие виды [5]:

- самостоятельные или репеллентные, которые отпугивают рыб, заставляя их самостоятельно уйти от источника опасности (поля электрические, световые, звуковые и другие);

- самостоятельно-принудительные или направляющие, они оказывают на рыб комплексное отпугивающее-транспортирующее воздействие, заставляя рыб самостоятельно удерживаться от ската к источнику опасности и стимулирующее их скат в безопасном направлении (турбулизированное водное течение, воздушнопузырьковое и тому подобное);

Так как основным объектом защиты является пассивно скатывающаяся молодь рыб, которая не имеет возможности самостоятельно уходить от источника опасности, а водная среда является наиболее естественной средой ее обитания и транспортным средством, то рассмотрена возможность использования, самостоятельно-принудительного - направляющего рабочего органа. Такое течение возможно создать уже рассмотренным выше струегенератором.

Исходя из проведенного анализа, предлагается конструкция универсального комплексного струереактивного рыбозащитного устройства барабанного типа для плавучих насосных станций.

Струереактивный рыбозаградитель (рис. 2) комбинированное рыбозащитное устройство, имеющее конструкцию в виде сетчатого барабана, имеющего форму усеченного конуса, которое по способу задержания молоди рыб с длиной тела более 15 мм относится к I группе, а молоди с длиной тела менее 15 мм - ко II группе, то есть к механическим и гидравлическим заграждениям, соответственно.

Данная конструкция рыбозащитного устройства водозабора, состоит из решетчатого 
сварного каркаса 1 , внутри которого расположен струегенератор - вращающаяся промывная флейта 2. Решетчатый каркас обтянут мелкоячеистой сеткой 3.

Большее основание каркаса рыбозаградителя закрыто крышкой с отверстием, равным по величине и форме входному отверстию водозабора-водоприемного патрубка 4. Отверстие оборудуется комингсом с уплотнением из мягкой резины. Меньшее (нижнее) основание и боковая конусная поверхность каркаса обтянуты мелкоячеистой нержавеющей сеткой $2 \times 2$ мм с ориентированием образующей усеченного конуса вдоль потока через которую вода поступает в водозабор. Внутри сегмента установлена промывное (отпугивающее/отгоняющее) приспособление - трубчатый распределитель трапецеидальной формы - подвижная промывная флейта, которая включает перфорированную трубу с кронштейном, закрепленную шарнирно. На боковых сторонах флейты расположены отверстия под углом к диаметральной плоскости рыбозаградителя таким образом, что вытекающие из них струи на противоположных ветвях, образуют реактивные силы, создающие крутящий момент, необходимый для вращения промывного приспособления. Причем отверстия перфорированной трубы направлены в противоположную сторону от оси поворота. Флейта вращается на двух подшипниках 5 и 6 вокруг оси усеченного конуса с частотой вращения, регулируемой на магистрали 7, подводящей воду от насоса к промывному приспособлению. Равномерное распределение скоростей в ячейках сетчатого полотна обеспечивается формой каркаса рыбозаградителя в виде усеченного конуса, расчетным режимом работы промывного приспособления, не допускающим засорение сетки.

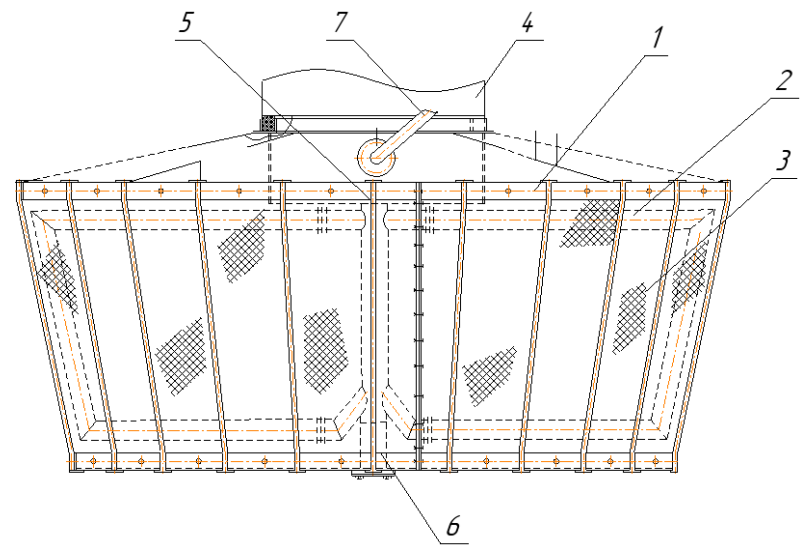

Рис. 2. Рыбозащитное устройство
Основным назначением струереактивного рыбозаградителя, в соответствие с его принципом действия, является обеспечение самостоятельного ухода молоди рыб с длиной тела более 15 мм и принудительного отвода молоди рыб с длиной тела менее 15 мм из зоны влияния водозабора без травмирования и гибели при контакте ее с элементами рыбозаградительного устройства. Полотно сетки будет являться надежным средством механической защиты молоди рыб с длиной тела более 15 мм. Рекомендуемые размеры ячеек 2 х2 мм меньше поперечных размеров их тела, а скорость течения воды в ячейках сетки равномерно распределена по поверхности рыбозаградителя, которая не должна превышать $0,25 \mathrm{~m} / \mathrm{c}$ [1]. Струи воды, вытекающие под давлением из промывного приспособления, создают турбулентный поток, являются средством гидравлической защиты молоди с длиной тела менее 15 мм, личинок и икры, которые без травмирования отбрасываются создаваемым потоком воды от сетки в зону течения в водотоке, относящего рыбу и мусор от водозабора.

Таким образом, рыбозащитное устройство с струегенератором предотвращает попадание молоди рыб, мусора и водорослей во всасывающий трубопровод насосной станции.

Контроль работы рыбозащитного устройства осуществляется по частоте вращения промывного приспособления, которая является независимым параметром контроля и регулировки режима работы устройства. Поэтому она принимается в качестве основного контролируемого эксплуатационного критерия надежности работы рыбозащитного устройства. Контроль частоты вращения промывного приспособления осуществляется датчиком частоты вращения, который чувствителен к металлу и устанавливается на каркас рыбозащитного устройства.

В проведенном анализе назначения и конструкции рыбозащитных устройств обоснована необходимость проектирования и изготовления универсального рыбозащитного устройства методом комбинирования с использованием в качестве потокоформирующего элемента струегенератора, создающего реактивное гидравлическое движение, предложена такая конструкция.

Предлагаемая конструкция рыбозащитного устройства относительно проста, поэтому не вызовет трудностей в проектировании, изготовлении и в дальнейшей эксплуатации. 


\section{БИБЛИОГРАФИЧЕСКИЙ СПИСОК}

1. СП 101.13330.2012 Подпорные стены, судоходные шлюзы, рыбопропускные и рыбозащитные сооружения. Актуализированная редакция СНиП 2.06.07-87.

2. Малинина, E. М. Рыбозащитные устройства / Е. М. Малинина, Е. В. Мозговая // Водоснабжение. Санитарная техника. - 2009. - С. 99-100.

3. Бегляров, Д. С. Влияние типов и конструкций рыбозащитных сооружений на сохранение рыбных популя- ций внутренних водоемов страны / Д. С. Бегляров, Е. С. Бакштанин, Е. С. Костина // Природообустройство. 2019. - № 5. - С. 66-67.

4. Иванов, А. В. Рыбозащитные сооружения на основе потокообразующих устройств / А. В. Иванов, Г. Г. Филиппов // НДТ. - 2017. - № 2. - С. 36-44.

5. Иванов, А. В. Обеспечение безопасности рыб на водозаборах: автореферат дис. ... д-ра техн. наук: 05.23.07 Иванов Александр Васильевич. - Москва, 2007. - 50 с.

УДК 681.5

DOI: $10.35211 / 1990-5297-2021-8-255-72-74$

М. П. Кухтик, А. И. Репников, Ю. П. Сердобинцев, М. А. Хаустов

РАЗРАБОТКА ПРОГРАММЫ УПРАВЛЕНИЯ И НМІ-ИНТЕРФЕЙСА ДЛЯ СИСТЕМЫ ПРЕДОТВРАЩЕНИЯ АВАРИЙНЫХ СИТУАЦИЙ В ОПОРЕ СКОЛЬЖЕНИЯ ГАЗОПЕРЕКАЧИВАЮЩЕГО АГРЕГАТА

Волгоградский государственный технический университет

E-mail: app@vstu.ru

Написана программа управления для автоматизированной системы предотвращения аварийных ситуаций в опоре скольжения газоперекачивающего агрегата. Разработан HMI-интерфейс панели управления оператора.

Ключевые слова: газоперекачивающий агрегат; опора скольжения; автоматизированная система; программа управления; НМІ-интерфейс.

\section{P. Kukhtik, A. I. Repnikov, Yu. P. Serdobintsev, M. A. Khaustov \\ DEVELOPMENT OF CONTROL PROGRAM AND HMI-INTERFACE FOR A SYSTEM OF PREVENTION OF EMERGENCY SITUATIONS IN A SLIDING SUPPORT OF A GAS PUMPING UNIT}

\section{Volgograd State Technical University}

Control program for automated system of prevention of emergency situations in a sliding support of a gas pumping unit has been written. HMI-interface of operator control panel has been developed.

Keywords: gas pumping unit; sliding support; automated system; control program; HMI-interface.

Одной из важнейших частей газоперекачивающих агрегатов (ГПА) является опора скольжения, состоящая из вала, антифрикционной втулки и подшипника скольжения. Если требуемый режим смазки не обеспечивается, то происходит перегрев подшипника скольжения и разрушение опоры скольжения. С целью предотвращения разрушения опоры скольжения ГПА разработана автоматизированная система предотвращения аварийных ситуаций [1].

В программной среде PCWorx создана программа управления, реализующая предложенный ранее алгоритм работы автоматизированной системы [2]. Разработка программы началась с конфигурации модуля широтноимпульсной модуляции и модуля дискретных выходов. После этого создан функциональный блок, который обрабатывает сигнал, получен- ный с датчика температуры, расположенного в подшипниковом узле.

Сама программа управления, состоящая из семи фрагментов кода, написана на структурированном языке ST.

В первом фрагменте прописывается выполнение условия возврата антифрикционных полимерных вставок, если они уже были смещены в результате сильного нагрева подшипника скольжения ГПА.

Во втором и третьем фрагментах происходит преобразование сигнала датчика температуры в реальную величину методом интерполяции и его сравнение с уставкой, введенной с НМІ-панели оператора. Если в процессе работы системы произошло нарушение режима трения по какой-либо причине и фактическое значение температуры превышает введенную ус-

(C) Кухтик М. П., Репников А. И., Сердобинцев Ю. П., Хаустов М. А., 2021. 
тавку дольше первой временной уставки, также введенной с НMI-панели, то программа управления начинает производить смещение антифрикционных полимерных вставок, посылая сигналы из контроллера на блоки управления шаговыми электродвигателями (ШЭД), которые начинают поворачивать свои валы на заданную величину. При этом подается преду- преждающее сообщение на панель оператора с соответствующим звуковым оповещением.

В четвертом фрагменте вычисляется количество шагов, пройденных валом ШЭД. Часть программы, реализующая условие начала срабатывания счетчика, выполняющего вычисление количества шагов, написана на языке функциональных блоков FBD (рис. 1).

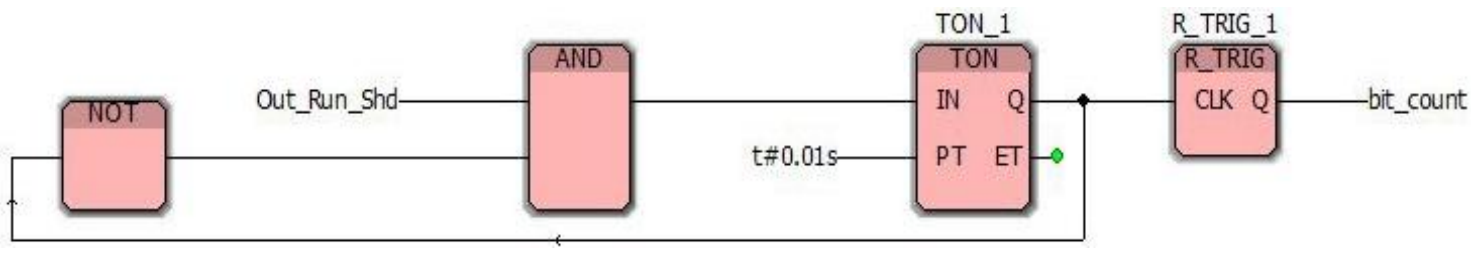

Рис. 1. Условие начала срабатывания счетчика ШЭД

В пятом и шестом фрагментах происходит преобразование сигнала датчика температуры в реальную величину методом интерполяции и его сравнение с уставкой, введенной с НMIпанели оператора. Если фактическое значение температуры превышает введенную уставку дольше второй временной уставки, также введенной с НМІ-панели, то программа управления подает дискретный сигнал на останов ГПА, выдав при этом соответствующее сообщение на панель оператора с соответствующим звуковым оповещением.

Для того чтобы на НMI-панель оператора выводились все необходимые аварийные сообщения, а также отображались значения счетчика ШЭД и значение температуры, полученное с датчика, необходимо обеспечить связь между программируемым логическим контроллером и НМІ-панелью оператора. С этой целью написан седьмой фрагмент программы управления и использован соответствующий функциональный блок из библиотеки «Modbus V1.32».

Для сенсорной графической панели оператора в среде EasyBuilder Pro разработан HMIинтерфейс, позволяющий визуализировать состояние автоматизированной системы и осуществлять управление [3]. Интерфейс панели оператора состоит из трех окон. На главном окне «Станция» (рис. 2) показаны ГПА, показания датчиков температуры, поля ввода уставок, а также кнопки управления, одна из которых сбрасывает счетчик количества шагов, пройденных ШЭД, а вторая - возвращает антифрикционные вставки, если была подана команда на смещение вставок в подшипнике скольжения.

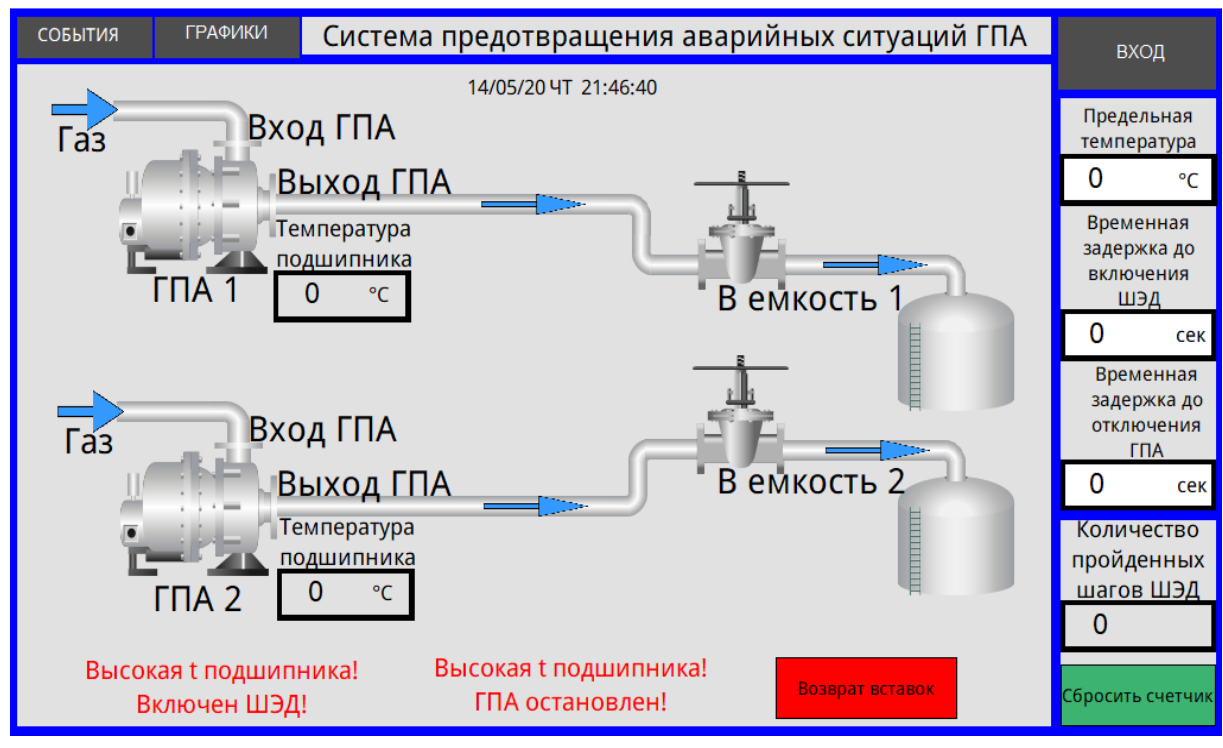

Рис. 2. Окно «Станция» 


Журнал сигналов/событий
Категория:
\begin{tabular}{|l|l|l|l|l|}
\hline Кол-во [3] & Категория & Текст & \multicolumn{2}{l|l}{} \\
\hline 1 & 0 & Высокая t подшипника. Включен ШЭД. & ВІТ & Условие \\
\hline 2 & 0 & ШЭД выключен & ВІТ \\
\hline 3 & 0 & Высокая t подшипника. ГПА остановлен. & ВІТ & OFF \\
\hline
\end{tabular}

Рис. 3. Окно «События»

Окно «События» (рис. 3) демонстрирует архивы всех событий и аварий, которые произошли в системе за 30 дней. Здесь представлены текстовые сообщения о работе системы и условия, при котором активируются конкретные переменные, формирующие эти сообщения.

С помощью окна «Вход» (рис. 4) выполня- ется вход в систему под одной из двух учетных записей - «Оператор» или «Сервисный инженер». Оператор может вводить уставки и наблюдать за значениями температуры подшипника скольжения, а сервисный инженер имеет дополнительный доступ к кнопкам сброса счетчика и возврата антифрикционных вставок.

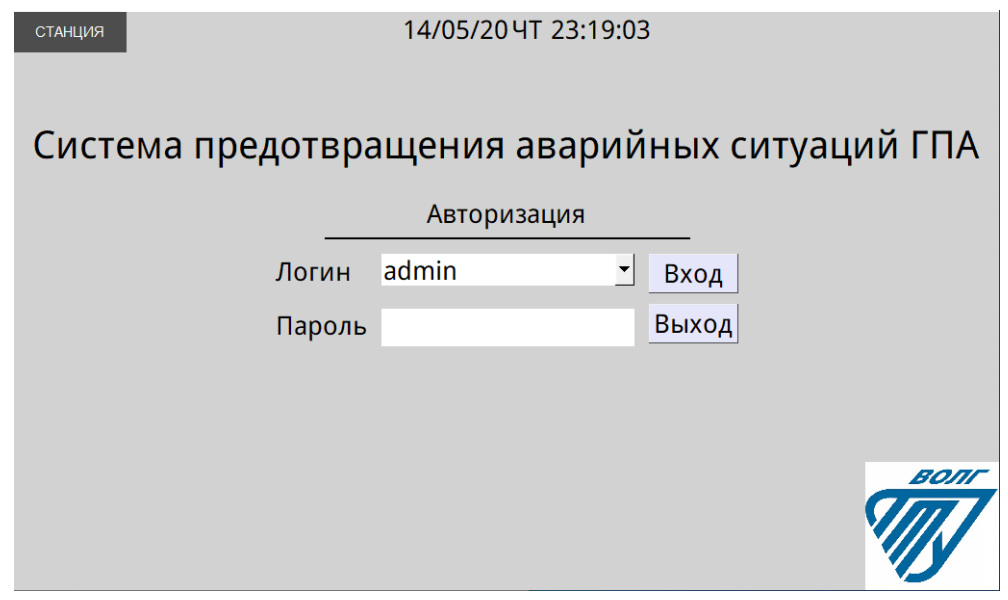

Рис. 4. Окно «Вход»

Внедрение разработанной автоматизированной системы предотвращения аварийных ситуаций в опоре скольжения ГПА позволит предотвратить выход из строя подшипников скольжения за счет мониторинга температуры в зоне контакта вала и втулки, сократив расходы на ремонт ГПА.

\section{БИБЛИОГРАФИЧЕСКИЙ СПИСОК}

1. Репников, А. И. Автоматизированная система предотвращения аварийных ситуаций в опорах скольжения газоперекачивающих агрегатов / А. И. Репников // XXIV Peгиональная конференция молодых ученых и исследователей
Волгоградской области. Волгоград, 3-6 декабря 2019 г. : сб. материалов конф. / ВолгГТУ ; редкол.: С. В. Кузьмин (отв. ред.) [и др.]. - Волгоград, 2020. - С. 92-93.

2. Репников, А. И. Автоматизированная система аварийного останова газоперекачивающего агрегата / А. И. Репников, М. П. Кухтик, Ю. П. Сердобинцев // Известия ВолгГТУ : научный журнал № 3 (238) / ВолгГТУ. - Волгоград, 2020. - (Серия «Прогрессивные технологии в машиностроении»). - С. 79-82.

3. Автоматизированная система предотвращения аварийных ситуаций в опоре скольжения газоперекачивающего агрегата / М. П. Кухтик, А. И. Репников, Ю. П. Сердобинцев, М. А. Хаустов // Известия ВолгГТУ : научный журнал № 1 (248) / ВолгГТУ. - Волгоград, 2021. - (Серия «Прогрессивные технологии в машиностроении»). - С. 67-69. 
УДК 681.532 .6

DOI: $10.35211 / 1990-5297-2021-8-255-75-78$

\section{А. М. Макаров, И. И. Давыдова, К. А. Драпак, Е. Г. Крылов \\ АВТОМАТИЗИРОВАННОЕ ЛЕЧЕБНО-ОЗДОРОВИТЕЛЬНОЕ УСТРОЙСТВО}

\section{Волгоградский государственный технический университет E-mail: app@vstu.ru}

В статье представлены пневматическая и функциональная схема автоматизированного лечебно-оздоровительного устройства (ЛОУ), разработана структура матрицы пневматических камер вдоль длины и ширины ЛОУ и диаграмма распределения нагрузки тела человека на ЛОУ в зависимости от соотношения нагрузки на поверхность.

Ключевые слова: лечебно-оздоровительное устройство, пневматическая камера, воздушная магистраль, микропроцессорное устройство управления.

\section{A. M. Makarov, I. I. Davydova, K. A. Drapak, E. G. Krylov}

\section{AUTOMATED MEDICAL AND HEALTH-IMPROVING DEVICE}

\section{Volgograd State Technical University}

The article presents a pneumatic and functional diagram of an automated medical and health-improving device (LOW), the structure of the matrix of pneumatic chambers along the length and width of the LOW and a diagram of the distribution of the human body load on the LOW, depending on the ratio of the load on the surface, are developed.

Keywords: medical and health-improving device, pneumatic chamber, air line, microprocessor control device.

В медицинских учреждениях к лечебно-оздоровительным устройствам часто предъявляются особые требования, связанные с необходимостью выполнения дополнительных функций при уходе за тяжелыми и лежачими больными [1]. Актуальной проблемой существующих автоматизированных лечебно-оздоровительных устройств является сложность конструкции, а также достаточно высокая стоимость, обусловленная большим количеством дорогостоящего оборудования. С целью устранения указанных недостатков было разработано лечебно-оздоровительное устройство (ЛОУ), исполнительным механизмом которого является матрица пневматических камер [2,3].
Согласно ГОСТ 19917-2014 размеры ложа больничной кровати составляют 1900 х 800 мм, поэтому длина и ширина матрицы должна соответствовать этим параметрам. На рис. 1 представлено распределение нагрузки вдоль длины ЛОУ в зависимости от процентного соотношения нагрузки на поверхность. Красным цветом выделена 1-я зона (голова, плечи), оранжевым 2-я зона (талия), желтым - 3-я зона (бедра), голубым - 4-я зона (ноги).

На рис. 1 длина указанных зон следующая:

1) зона 1 - голова, плечи (0-45 cм);

2) зона 2 - талии $(45-80 \mathrm{~cm})$;

3) зона 3 - бедра (80-125 см);

4) зона 4 - колени, икры, ступни (125-210 см)

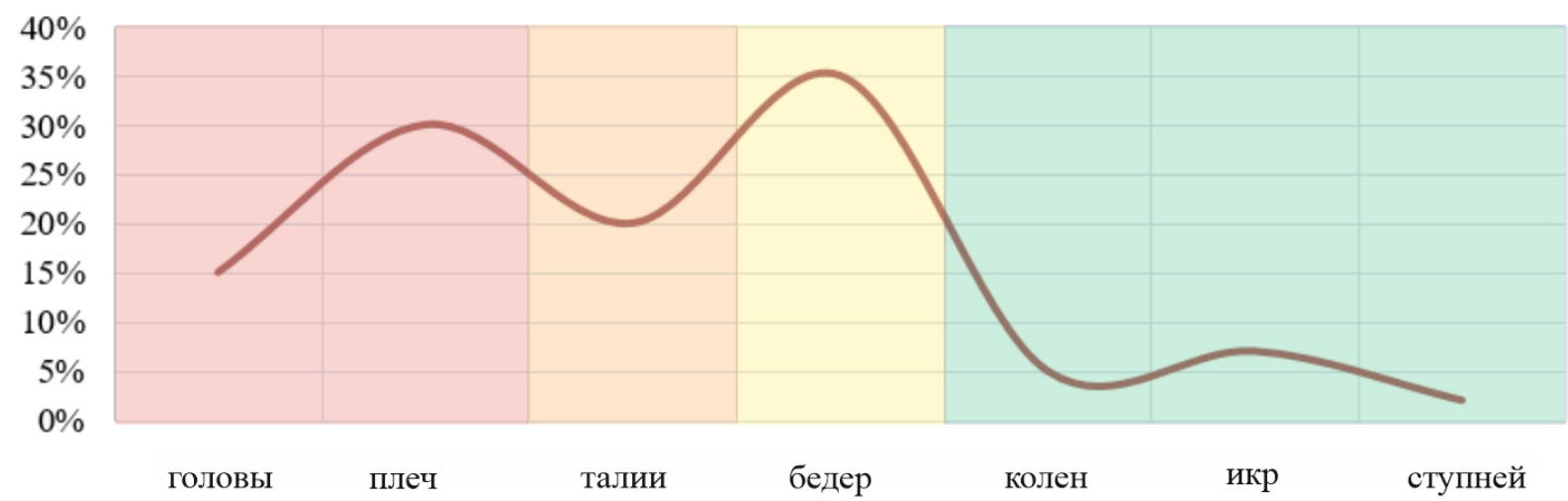

Рис. 1. Распределение нагрузки тела человека на ЛОУ вдоль его длины в зависимости от процентного соотношения нагрузки на поверхность

(C) Макаров А. М., Давыдова И. И., Драпак К. А., Крылов Е. Г., 2021. 
Следовательно, минимально необходимое количество ячеек матрицы пневматических камер вдоль длинной стороны (ЛОУ) - четыре. Нагрузка на каждую камеру будет разная, соответственно для создания комфортных условий в них нужно будет поддерживать разное давление.

Эскиз разреза разрабатываемой матрицы пневматических камер вдоль ее длины, представлен на рис. 2.

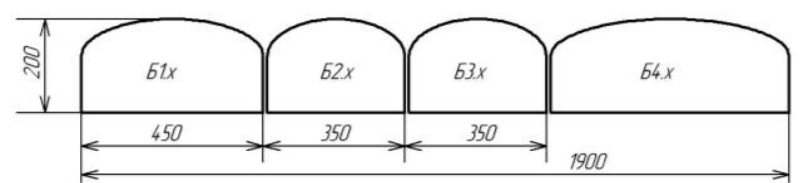

Рис. 2. Структура матрицы пневматических камер по длине ЛОУ
Для обеспечения комфортного положения пациента по ширине матрицы ЛОУ используется три ряда пневматических камер (рис. 3).

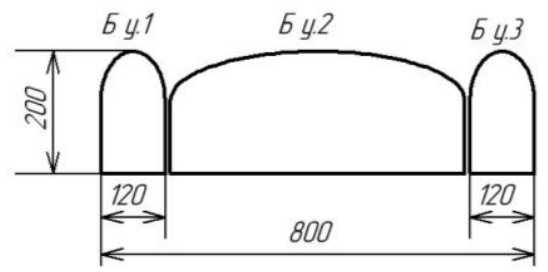

Рис. 3. Структура матрицы пневматических камер по ширине ЛОУ

Эскиз матрицы пневматических камер ЛОУ (вид сверху) представлен на рис. 4.

\begin{tabular}{|c|c|c|c|c|}
\hline$\approx 4$ & 51.3 & 52.3 & 63.3 & 64.3 \\
\hline ని & 51.2 & 52.2 & 63.2 & 64.2 \\
\hline$\vee \approx \downarrow$ & E1.1 & 52.1 & E3.1 & 64.1 \\
\hline & 450 & 350 & 350 & \\
\hline
\end{tabular}

Рис. 4. Структура матрицы пневматических камер ЛОУ (вид сверху)

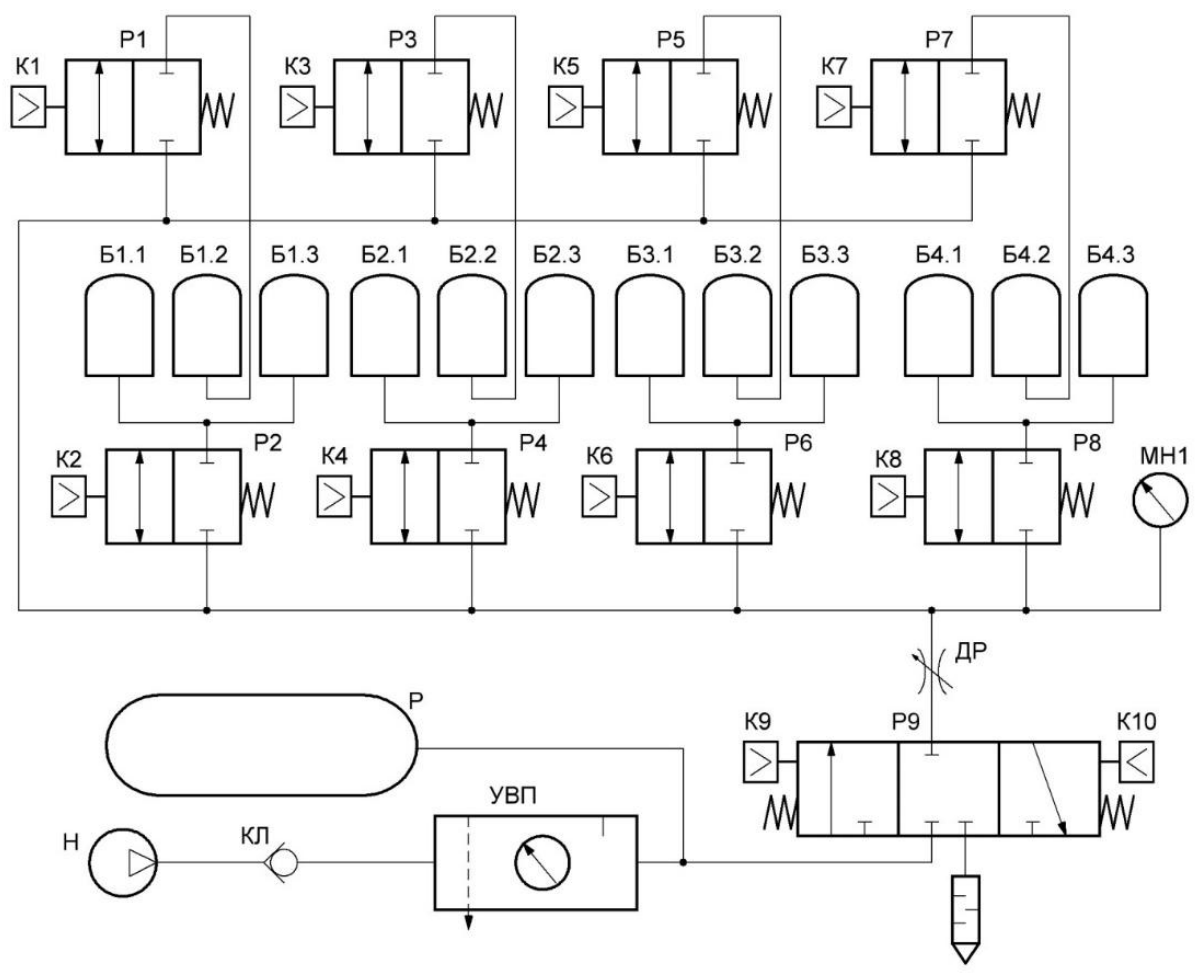

Рис. 5. ЛОУ. Схема пневматическая функциональная 
Для идентификации положения пневматических камер в ЛОУ используются позиционные обозначения типа Б $y . x$, где $y$ - позиция камеры вдоль узкой стороны матрицы; $x$ - позиция камеры вдоль длины матрицы.

Пневматическая схема ЛОУ приведена на рис. 5.

Избыточное давление воздуха для поддержания камер в рабочем состоянии создается компрессором Н. Сжатый компрессором Н воздух проходит через устройство воздухоподготовки УВП, в состав которого входят фильтр масло/влагоотделитель и стрелочный манометр. Ресивер Р сглаживает пульсации давления воздуха на выходе компрессора Н и содержит некоторый запас сжатого воздуха, что сокращает количество включений-выключений компрессора в процессе работы ЛОУ.

Пневматические камеры Б1.2, Б2.2, Б3.2 и Б 4.2, расположенные в среднем ряду матрицы, по команде устройства управления могут подключаться к воздушной магистрали открыванием клапанов Р1, Р3, Р5, Р7.

Крайние вдоль длины ЛОУ пневматические камеры каждой секции матрицы объединены попарно: Б1.1 и Б1.3, Б2.1 и Б2.3, Б3.1 и Б3.3, Б4.1 и Б4.3 и по команде устройства управления могут подключаться к воздушной магистрали открыванием клапанов Р2, P4, P6, P8.

Функциональная схема ЛОУ приведена на рис. 6.
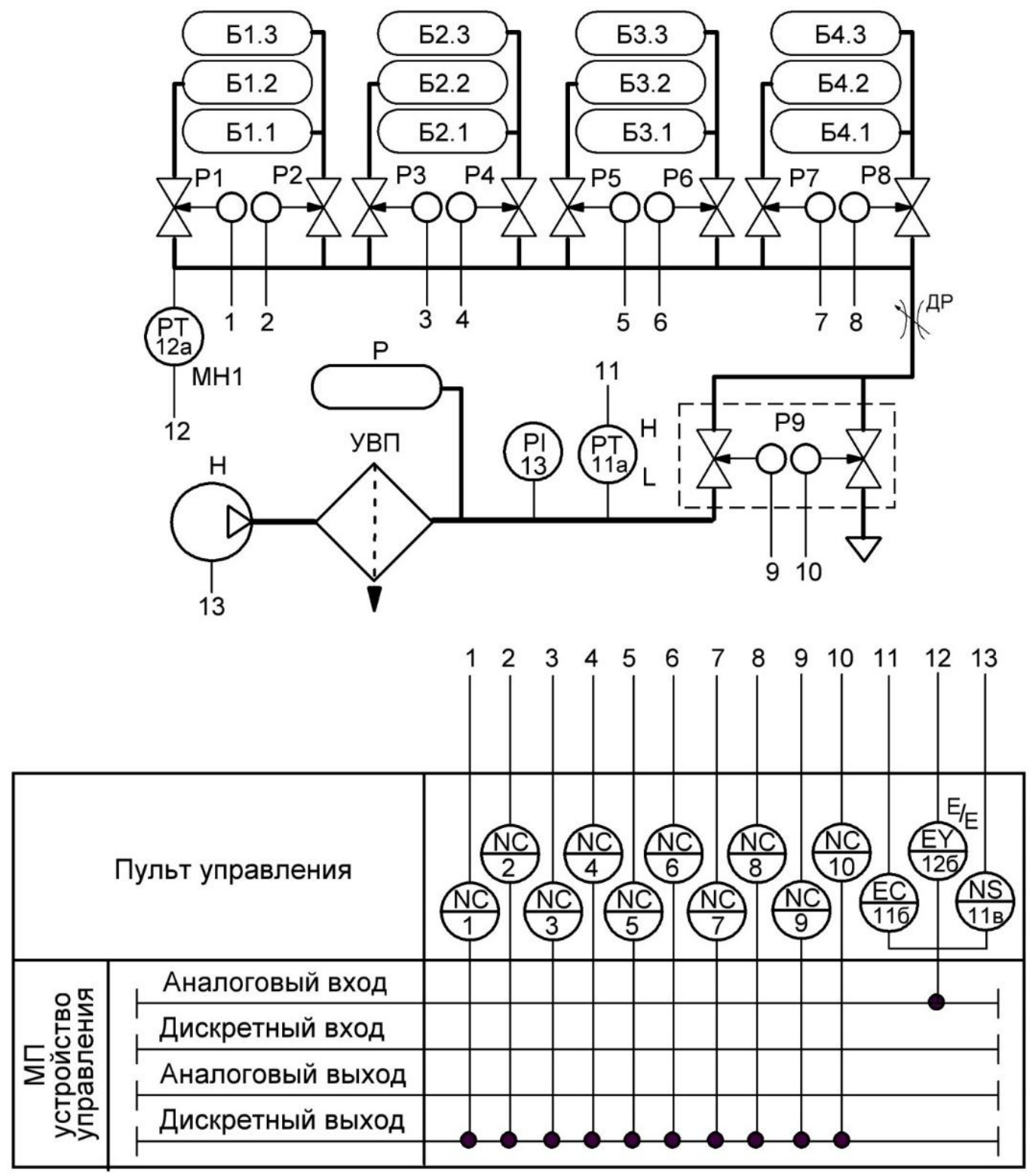

Рис. 6. ЛОУ. Схема комбинированная функциональная 
Исполнительный механизм ЛОУ представляет собой матрицу, состоящую из определенным образом расположенных двенадцати пневматических камер Б1.1 - Б4.3. Пневматические камеры с помощью пневматических клапанов P1-P8 циклически поочередно подключаются к воздушной магистрали. Управление клапанами производится сигналами дискретных выходов микропроцессорного устройства управления (МПУ) через устройства коммутации поз. 1-8.

Давление воздуха в магистрали измеряется манометром MH1 с электрическим выходом, поз. 12а. Измерительный сигнал с выхода манометра МН1 поступает на аналоговый вход МПУ. Воздушная магистраль, объединяющая клапана P1-P8, через регулируемый дроссель ДР подключена к трехходовому пневмораспределителю Р9. Клапан Р9 по командам МПУ соединяет воздушную магистраль с ресивером $\mathrm{P}$ или сбрасывает воздух из магистрали в атмосферу через глушитель. Управление пневмораспределителем Р9 производится сигналами дискретных выходов МПУ через устройства коммутации поз. 9-10.

Элементы цепочки поз. 11 - дискретный датчик давления (поз. 11a) с переключением по нижнему и верхнему уровню давления в ресивере, регулирующее устройство (поз. 11б), устройство коммутации (поз. 11в) образуют ло- кальный контур системы подержания давления воздуха в ресивере Р. При снижении давления воздуха в ресивере $\mathrm{P}$ меньше нижнего предела включается компрессор Н. При повышении давления выше верхнего предела компрессор $\mathrm{H}$ отключается. Обратный клапан КЛ не позволяет воздуху из ресивера выходить в атмосферу через неработающий механизм компрессора $\mathrm{H}$.

Таким образом, уменьшение количества используемых пневматических камер позволило снизить стоимость ЛОУ при одновременном обеспечении его надежности и эффективности.

\section{БИБЛИОГРАФИЧЕСКИЙ СПИСОК}

1. Адаптивное лечебно-оздоровительное устройство с переменной жесткостью / А. А. Чикова, Е. С. Чеснокова, И. В. Волков, А. М. Макаров // Известия ВолгГТУ : научный журнал № 1 (156) / ВолгГТУ. - Волгоград, 2015. (Серия «Прогрессивные технологии в машиностроении»). C. $74-76$.

2. П.м. № 162392 РФ, МПК А61G7/057. Лечебно-о3доровительное устройство / А. М. Макаров, И. В. Волков, Е. С. Чеснокова; заявитель и патентообладатель ФГБОУ ВО «Волгоградский государственный технический университет» (ВолгГТУ). - 2015150405/12; заявл. 24.11.2015; опубл. 10.06.2016. Бюл. № 16.

3. П.м. № 152344 РФ, МПК А61G7/057. Лечебнооздоровительное устройство / А. М. Макаров, И. В. Волков, А. А. Чикова; заявитель и патентообладатель ФГБОУ ВПО «Волгоградский государственный технический университет» (ВолгГТУ). - 2014105075/12; заявл. 11.02.2014; опубл. 20.05.2015. Бюл. № 14.

УДК 654.071.3

DOI: $10.35211 / 1990-5297-2021-8-255-78-80$

\section{А. С. Панюлайтис, В. Г. Барабанов, П. С. Васильев \\ РАЗРАБОТКА АВТОМАТИЗИРОВАННОЙ СИСТЕМЫ ИСПАРИТЕЛЬНОГО ОХЛАЖДЕНИЯ МЕТОДИЧЕСКИХ ПЕЧЕЙ С ИСПОЛЬЗОВАНИЕМ ГИДРАВЛИЧЕСКИХ ФОРСУНОК И КАПЕЛЬНОГО КИПЕНИЯ ЖИДКОСТИ}

Волгоградский государственный технический университет

E-mail: app@vstu.ru

Разработана новая система испарительного охлаждения методических печей. Описан процесс разработки. Разработана схема автоматизации данного устройства испарительного охлаждения. Дано описание основных элементов системы. Описаны основные преимущества использования гидравлических форсунок. Подробно описан процесс функционирования новой автоматизированной системы.

Ключевые слова: испарительное охлаждение, методические печи, форсунки, охлаждение, металлургия.

\section{A. S. Panuylaitis, V. G. Barabanov, P. S. Vasiliev \\ DEVELOPMENT OF AN AUTOMATED SYSTEM FOR EVAPORATIVE COOLING OF METHODICAL FURNACES USING HYDRAULICNOZZLES AND DROPLET BOILING OF LIQUID \\ Volgograd State Technical University}

A new system for evaporative cooling of continuous furnaces has been developed. The development process is described. An automation scheme for this evaporative cooling device has been developed. The description of the main elements of the system is given. The main advantages of using hydraulic nozzles are described. The process of functioning of the new automated system is described in detail.

Keywords: evaporative cooling, method furnaces, nozzles, cooling, metallurgy.

(c) Панюлайтис А. С., Барабанов В. Г., Васильев П. С., 2021. 
Надежная работа металлургической печи зависит от качества огнеупорных материалов, конструкции и стойкости охлаждаемых элементов и осуществима только при правильном охлаждении. Система охлаждения существенно влияет на конструкцию печи, ее фундаментальность и надежность.

Для охлаждения элементов печей, находящихся в зоне высоких температур, на металлургических заводах используют воду. Расход воды, идущей на охлаждение, в среднем составляет 95\% общего расхода, затрачиваемого на технические нужды.

Охлаждение элементов и узлов металлургических печей, работающих в тяжелых температурных условиях, позволяет: предохранять их от прогара, повышать стойкость кладки, обеспечивать неизменность профиля печи.

Нагревательные печи для обеспечения нижнего подогрева слитков оборудованы подовыми трубами, охлаждаемыми водой. Современное качество огнеупоров не может обеспечить длительную стойкость передней стенки печи, а ремонт ее - операция весьма трудоемкая.

Испарительное охлаждение металлургических печей в настоящее время является наиболее совершенным и экономичным. Применение его увеличивает срок службы металлургических печей и повышает надежность их работы, устраняет прогар деталей, сокращает расход охлаждающей воды и дает возможность использовать тепло

При испарительном охлаждении металлургических печей используют в основном скрытую теплоту парообразования для отвода тепла от охлаждаемых деталей. Применяемую обычно холодную охлаждающую воду заменяют кипящей, отвод тепла осуществляется за счет выхода пара.

Тепло, отбираемое водой, затрачивается на ее испарение. Так как скрытая теплота парообразования составляет 540 ккал/кг при атмосферном давлении, то каждый килограмм воды, испаряясь, отбирает от стенки охлаждаемой детали 540 ккал.

В зависимости от плотности теплового потока, подводимого к жидкости через соприкасающуюся с ней поверхность нагрева, на последней образуются отдельные паровые пузыри или сплошной слой пара. Процесс образования пара в виде пузырей, возникающих на отдельных местах поверхности нагрева (центрах парообразования), называют пузырьковым (ядерным) кипением. Процесс, сопровождающийся возникновением сплошного слоя пара между поверхностью нагрева и жидкостью, называют пленочным кипением [1].

При пузырьковом кипении жидкость непосредственно омывает поверхность нагрева между действующими центрами парообразования, причем ее пограничный слой перемешивается образующимися в нем паровыми пузырями. Вследствие этого интенсивность теплоотдачи к жидкости при пузырьковом кипении весьма велика и возрастает с увеличением числа действующих центров парообразования. При пленочном кипении жидкость отделена от поверхности нагрева слоем малотеплопроводного пара, вследствие чего интенсивность теплоотдачи во много раз меньше, чем при пузырьковом кипении. По этой причине переход от пузырькового режима кипения к пленочному, при неизменной плотности теплового потока, сопровождается резким возрастанием температуры поверхности нагрева [2, 3].

Использование капельного кипения позволяет в несколько раз повысить интенсивность процесса испарения и, соответственно, увеличить эффективность работы испарительного охлаждения методических печей.

По анализу зависимости времени испарения от температурного напора и стадий испарения капли можно сделать вывод, что для наибольшего отвода тепла от глиссажных и подовных труб, необходимо чтобы переход (испарение) капли воды происходил именно из сфероидального состояния. Из этого вывода понятно, что нельзя заливать трубы технической водой, а наоборот давать каплям испариться и вывести наибольшее количества тепла от деталей методической печи.

Для данного условия работы системы испарительного охлаждения необходимо распылять капли технической воды на глиссажные и подовные трубы из специально подобранных гидравлических форсунок, которые помогают доставить капли и равномерно распределить их количество по трубам. Примерная схема автоматизированной системы испарительного охлаждения с использованием гидравлических форсунок представлена на рисунке.

Для правильной и эффективной работы новой системы испарительного охлаждения необходима автоматизация данной установки [4]. Для определения температуры глиссажных труб требуется установить датчик температуры, который будет отслеживать температурный 
режим трубы в данный момент. В зависимости от установившегося значения, система либо отключается (если температура находится в допустимом диапазоне), либо начинается процесс испарительного охлаждения, то есть насос начинает нагнетать воду из бака в систему труб с гидравлическими форсунками. Капли воды начинают охлаждать глиссажные трубы.

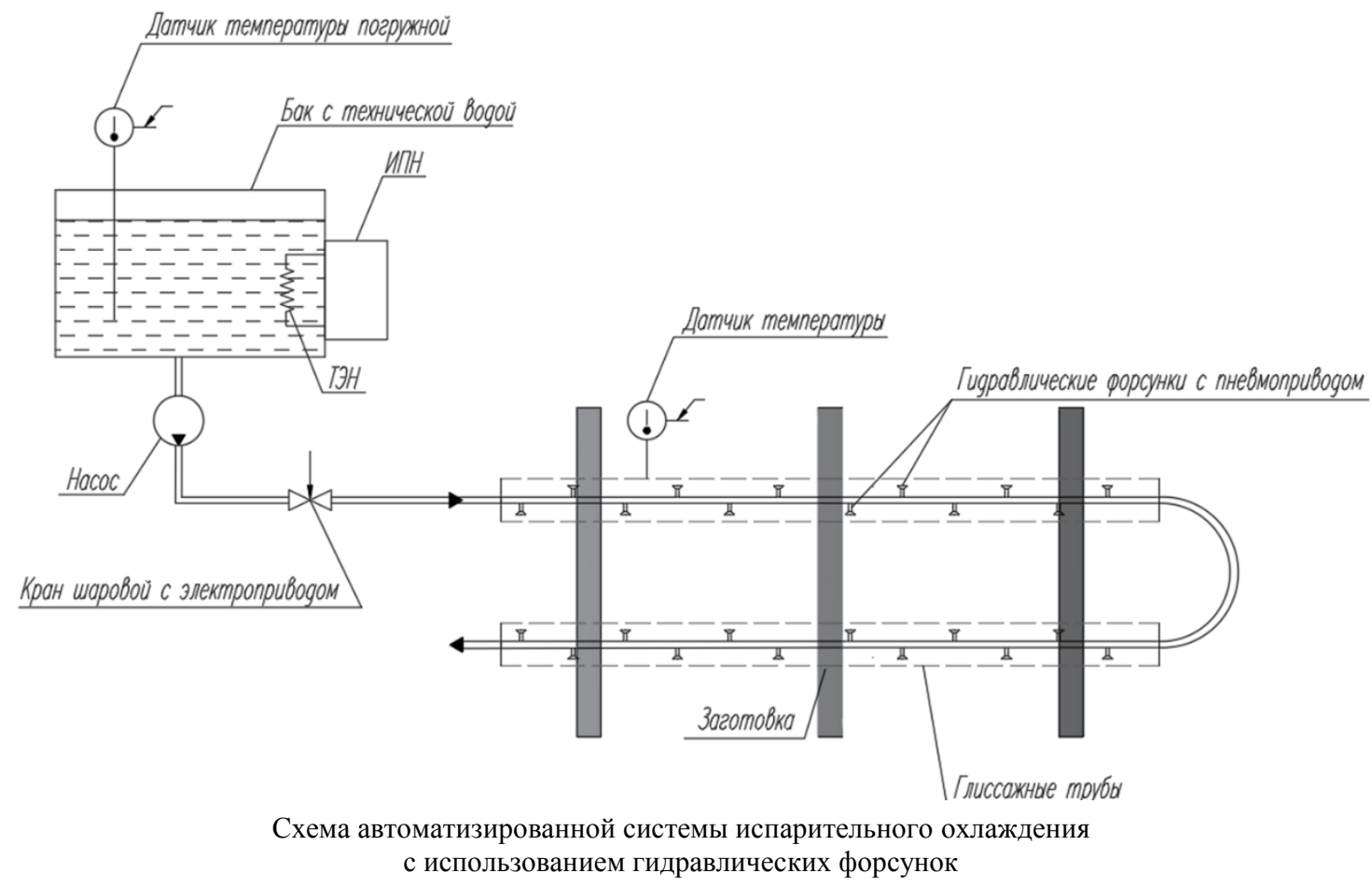

Если температура находится на критическом уровне, то система при помощи пневмоприводов на гидравлических форсунках переключает положение распылителей на больший диаметр получаемых капель, в результате чего происходит более интенсивное охлаждение труб.

Для испарительного охлаждения используется техническая вода, температура которой должна быть приближена к температуре кипения. Данная вода находится в рабочем баке, внутри которого необходимо установить ТЭН, при помощи которого будет осуществляться процесс ее нагрева до нужной температуры. Для контроля температуры воды в систему бака также необходимо установить датчик температуры погружной.

Управление данной системой будет осуществляться при помощи микропроцессорного контроллера.

Данная установка позволит сократить расходы технической воды для работы системы испарительного охлаждения, при этом эффективность данного охлаждения возрастет примерно в 1,4 раза (700 ккал).

\section{БИБЛИОГРАФИЧЕСКИЙ СПИСОК}

1. Патанкар, $C$. Тепло- и массообмен в пограничных слоях / С. Патакар, Д. Сполдинг; пер. с англ. 3. П. Шульмана, Г. Н. Пустынцева, под ред. А. В. Лыкова. - М. : Энергия, 1971. - $128 \mathrm{c}$.

2. Кутателадзе, С. С. Теплопередача при конденсации и кипении / С. С. Кутателадзе. -2-е изд., доп. и перераб. - М.; Л.: Машгиз, 1952. -233 с.

3. Васильев, П. С. Теплообмен при капельном кипении жидкости в технологических аппаратах : дис. ... канд. тех. наук: 05.17.08: защищена 12.02.18: утв. 15.02.18 / Васильев Петр Сергеевич. - Волгоград, 2018. - 245 с.

4. Панюлайтис, A. С. Автоматизированное устройство испарительного охлаждения методических печей с использованием гидравлических форсунок / А. С. Панюлайтис, В. Г. Барабанов, П. С. Васильев // Известия ВолгГТУ : научный журнал № 1 (248) / ВолгГТУ. - Волгоград, 2021. (Серия «Прогрессивные технологии в машиностроении»). C. 73-76. 
УДК 621.792 .6

DOI: 10.35211/1990-5297-2021-8-255-81-86

\section{И. С. Торубаров, А. В. Дроботов, А. Л. Плотников, И. А. Гущцин \\ РАЗВИТИЕ ТЕХНОЛОГИИ ЗD ПЕЧАТИ С АРМИРОВАНИЕМ НЕПРЕРЫВНЫМ ВОЛОКНОМ*}

Волгоградский государственный технический университет

E-mail: is.torubarov@gmail.com

Исследованы методы армирования изделий в аддитивном производстве с помощью непрерывных волокон, и обозначены общие проблемы, свойственные технологиям 3D печати, в том числе печати с непрерывным армированием. Предложено направление развития метода упрочнения изделий непрерывным волокном на основе многокоординатной печати изделий с неплоскими слоями.

Ключевые слова: аддитивные технологии, композиционный материал, непрерывное армирование, непрерывное углеволокно.

\section{S. Torubarov, A. V. Drobotov, A. L. Plotnikov, I. A. Gushchin \\ EVOLVEMENT OF THE 3D PRINTING WITH REINFORCEMENT BY CONTINUOUS FIBER' TECHNOLOGY}

Volgograd State Technical University

Methods of reinforcing products in additive manufacturing using continuous fibers was investigated in the paper, and also common problems inherent in 3D printing technologies including printing with continuous reinforcement was identified. The direction of development of the method of strengthening products with continuous fiber based on multi-axis printing of products with non-planar layers is proposed.

Keywords: additive manufacturing, composite material, continuous reinforcement, continuous carbon fiber.

Аддитивные технологии (АТ), созданные как средство быстрого прототипирования, уже сейчас получают признание и в качестве способа получения конечных объектов производства. Для некоторых изделий они выступают наряду с традиционными способами изготовления, такими как механическая обработка или литье, или даже вытесняют их. АТ активно применяют при изготовлении пресс-форм и форм для литья, функциональных элементов авиационной и ракетно-космической техники, имплантов и протезов [1].

По сравнению с традиционными металлообрабатывающими станками установки аддитивного производства (АП) обладают рядом преимуществ, связанных в первую очередь с аддитивным характером производства (т. е. наращиванием материала вместо его срезания с заготовки): экологичность, экономичность, малый износ рабочего инструмента, меньшие требования к жесткости системы, быстрота и высокая степень автоматизации процесса подготовки производства, а также сокращение времени и стоимости при проведении НИОКР. Отдельно следует отметить возможность построения моделей со сложной внешней формой и неоднородной внутренней структурой.
В силу простоты и дешевизны как оборудования, так и используемых материалов наибольшее распространение среди АТ получила технология производства методом наплавления материала (Fused Filament Fabrication, FFF) как правило, термопластичного полимера. Однако при производстве конечных изделий по этой технологии на первое место выходит вопрос прочности. В силу физических свойств полимерных материалов при плавлении их макромолекулы вытягиваются в направлении течения, в результате чего напечатанные по методу FFF объекты отличаются выраженной анизотропией механических свойств, что было показано, например, в работах [2, 3]: прочность изделий вдоль слоев существенно выше, чем в перпендикулярном направлении.

К периоду между 2015 и 2020 гг. в FFF-печати большое распространение получил такой способ повышения прочности, как использование филаментов, наполненных рубленым волокном. При испытаниях на растяжение и сжатие такие материалы показывали прочность уже на уровне пластиков, изготовленных литьем под давлением или пултрузией [4]. Однако эти характеристики получены с приложением усилия в плоскости слоя. Величина межслой-

\footnotetext{
(C) Торубаров И. С., Дроботов А. В., Плотников А. Л., Гущин И. А., 2021.

* Работа выполнена при финансовой поддержке гранта фонда «Сколково» № МГ18/20.
} 
ной прочности для наполненных термопластиков мало отличается от ненаполненных материалов.

В работе [5] анализировались возможные подходы к повышению прочности печатных изделий: оптимизация параметров процесса производства и использование высокотемпературных полимеров (таких как PEEK и ULTEMпластики с температурой плавления около $400^{\circ} \mathrm{C}$ ), печать моделей изогнутыми слоями вместо плоских и многоосевая печать. В отдельных случаях они обеспечивают некоторый прирост прочности, а применение многоосевой печати даже позволяет практически нивелировать анизотропию.

Однако у производства всегда стоит задача «еще прочнее и легче». И на данный момент самым перспективным способом дальнейшего повышения прочности полимеров является ис- пользование непрерывных армирующих волокон. Статья [6] представляет актуальный (на конец 2020 г.) обзор разработанных методов укладки термопластика с непрерывными волокнами, которые схематично изображены на рис. 1.

Исторически первыми методами являются печать с пропиткой волокна на месте (In-situ Impregnation) и с проточной пропиткой (Inline Impregnation). В этих случаях жгут из сухих волокон проходит через емкость с жидким связующим в экструдере (In-situ) или перед экструдером, например, в ванне (Inline), после чего через сопло экструдера укладывается на платформу. Связующее либо самостоятельно застывает при охлаждении (если использовался термопластик), либо подвергается внешнему воздействию (например, фотополимерное связующее отверждают УФ-излучением).
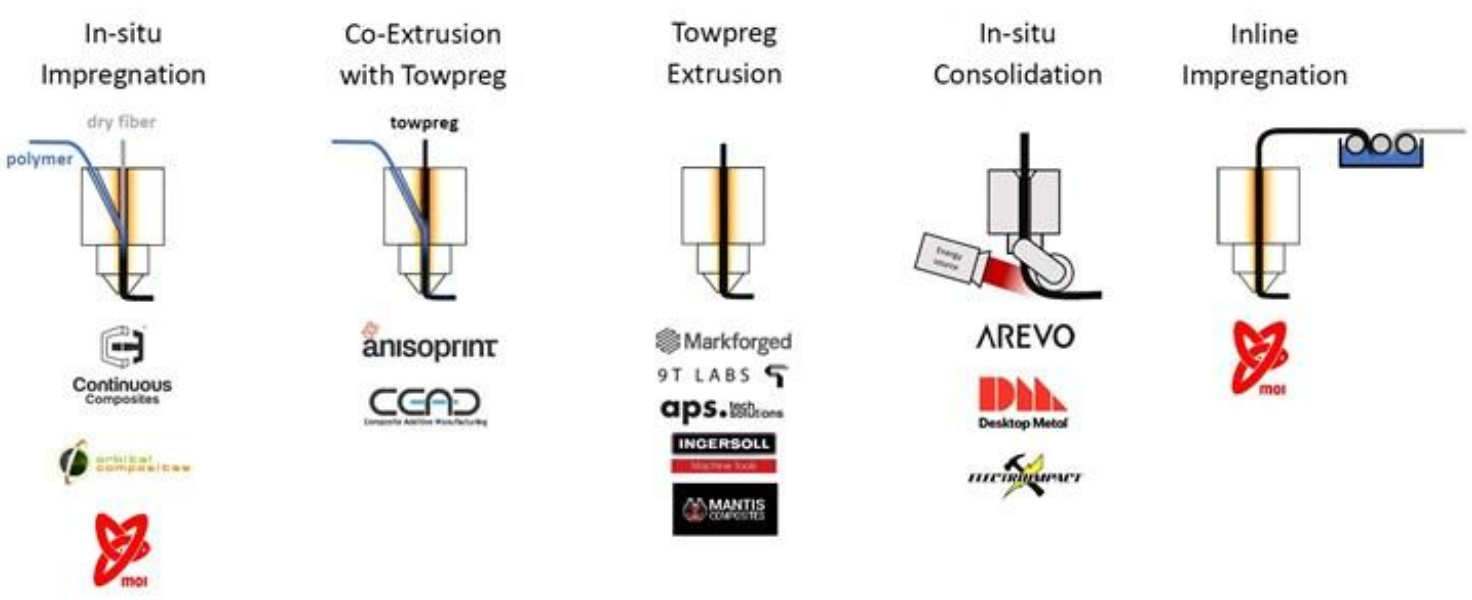

Рис. 1.Принципиальные схемы укладки непрерывного волокна в процессе 3D печати

Как поточная, так и «местная» пропитка волокна имела один общий недостаток: невозможность обеспечить таким образом полную и равномерную пропитку всего жгута, что приводило к возникновению пор. На решение этой проблемы были направлены методы печати с экструзией препрега (Towpreg Extrusion) и коэкструзией связующего с препрегом (CoExtrusion with Towpreg): в этом случае использовалось волокно, предварительно пропитанное неким связующим материалом в ходе отдельного процесса (собственно, препрег), за счет чего удалось почти полностью устранить пористость в жгуте.

Пионером в этой области выступила американская компания Markforged. Технология Markforged основывается на использовании препрегов с термопластичным связующим, в первую очередь - на основе нейлона (Onyx смесь нейлона с наполнителем из коротких углеродных волокон). По данным о прочности материалов Markforged за 2020 г. предел прочности образцов из нейлона, армированного непрерывным углеродным волокном, составил 800 МПа при растяжении и 540 МПа при изгибе, что в обоих случаях примерно в 10 раз превышает показатели для пластиковых образцов [7], и даже превосходит результаты лучших алюминиевых сплавов.

По пути коэкструзии препрега со связующим материалом пошла российская компания Anisoprint. Как материал для пропитки жгута был использован реактопласт - в отличие от термопластиков, этот класс полимеров после 
нагрева, облучения или т. п. обработки затвердевает окончательно и не плавится каждый раз при нагреве. В качестве «связующего», для образования «тела» изделия, используется все тот же термопластик, который экструдируется в процессе печати одновременно с подачей нагретого препрега.

Среди недостатков всех технологий печати с укладкой непрерывного волокна можно отметить слабость межслойного взаимодействия все так же на уровне стандартной 3D печати или немногим выше [8], наличие пор на границах раздела матрицы и арматуры, а также невысокую производительность.

На решение проблем пористости был нацелен способ соединения (консолидации) на месте (In-situ Consolidation), разработанный компанией Arevo. Суть процесса заключается в подаче препрега, его резком нагреве с помощью лазера и соединении с предыдущим слоем посредством прижимного ролика. Предварительное исследование [8], проведенное компанией, показало прочность образцов при стандартных испытаниях на уровне данных Markforged или вдвое выше при однонаправленной укладке волокон (что естественным образом ухудшает механические характеристики во всех остальных направлениях).

Однако ни один из описанных выше методов не направлен на решение первичной проблемы: низкой прочности печатных изделий в направлении, перпендикулярном плоскости построения. Этот факт отмечается, например, в исследовании [9]. Там же предлагается способ упрочнения композитного печатного объекта: т. н. «Z-pinning»: оформление в модели специальных вертикальных отверстий и пропускание через них композитного филамента, который обеспечивает «сшивание» плоских слоев и принимает на себя нагрузку, приложенную перпендикулярно слоям. Данный способ имеет ограниченное применение и к тому же грозит образованием значительных пор в местах «сшивания». Тем не менее, он ясно показывает потребность в таких 3D печатных структурах, которые, безусловно, будут уступать «однонаправленным» образцам при растяжении вдоль слоев, но показывать лучшие результаты при более сложных способах нагружения.
Проведенный анализ способов армирования в современном аддитивном производстве и их недостатков делает очевидным направление дальнейшего развития: построение изделия не из плоских слоев, т. к. при этом в принципе нельзя избавится от слабой межслойной прочности, а путем выкладки материала по объемным (пространственным) траекториям. В настоящей работе авторами сделан следующий шаг: совмещены в одном процессе аддитивного производства композитная и многоосевая печать. Использование в многокоординатной установке АП композитного филамента на основе непрерывного волокна позволит многократно повысить прочность печатного изделия (по сравнению с неармированной 3D печатью), обеспечив при этом его способность эффективно противостоять разным видам нагрузки, действующим в различных направлениях. Увеличение прочности и сглаживание анизотропии реализация двух этих требований еще больше раздвинет границы возможностей АП.

Как отмечено выше, вопросы армирования непрерывным волокном по плоским слоям уже рассматривались другими научными коллективами, а вот вопросы многоосевой печати решались только в «ручном» режиме. Для немногочисленных опытов использования сразу нескольких (более трех) осей для 3D печати управляющая программа составлялась практически вручную. Никаких универсальных подходов для автоматического получения G-кода программы производства изделия по его $3 \mathrm{D}$ модели ранее не предлагалось. Поэтому авторами предложен собственный алгоритм подготовки изделий к печати, использующий пять степеней свободы для позиционирования заготовки (печатной платформы) и инструмента (экструдера).

Процесс 3D печати изделия по пяти координатам схематично изображен на рис. 2. Кинематика устройства была описана в работе [10]. В общем виде процесс состоит из трех этапов: производство поддерживающей оснастки на цилиндрической приемной поверхности, создание на нем первой части изделия (сердечника цилиндрической или любой другой формы), послойное наложение материала на первую часть по пространственным траекториям. 


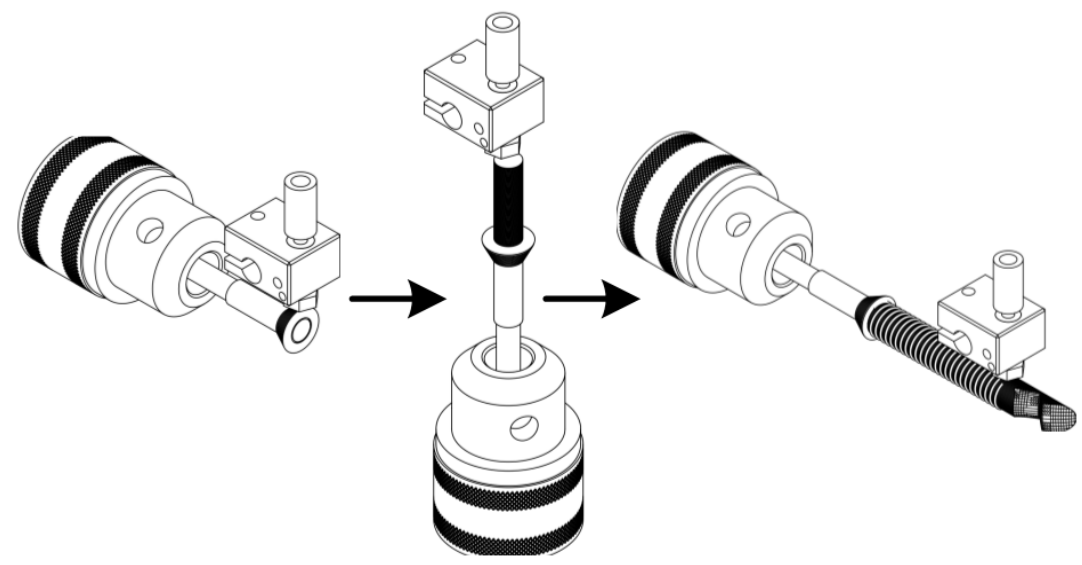

Рис. 2. Схема процесса 3D печати по пяти координатам

Для реализации данного подхода для 3D моделей практически произвольной формы авторами разработано собственное программное обеспечение. В его основу положен популярный слайсер «Ultimaker Cura» с открытым исходным кодом, но алгоритм генерации траекторий движения печатающей головки в нем заменен на собственный. Интерфейс разработанной программы показан на рис. 3 .

Для обеспечения возможности армирования изделия непрерывным волокном разрабатываемый слайсер был доработан с целью печати одного изделия двумя материалами: основным термопластичным материалом и препрегом.
Траектория выкладки прерпега генерируется специальным образом: выбирается наиболее длинная траектория с минимизацией количества разрывов. Также внедрено управление «ножом», отрезающим препрег в нужный момент времени. Определение момента отреза происходит с учетом расстояния между «ножом» и соплом для выкладки препрега: в каждом слое отрез происходит заранее, после чего отрезанный участок выкладывается в конце траектории. Слайсер позволяет комбинировать внутри изделия произвольное количество армирующих слоев и слоев основного материала, гибко регулируя плотность волокон в слое.

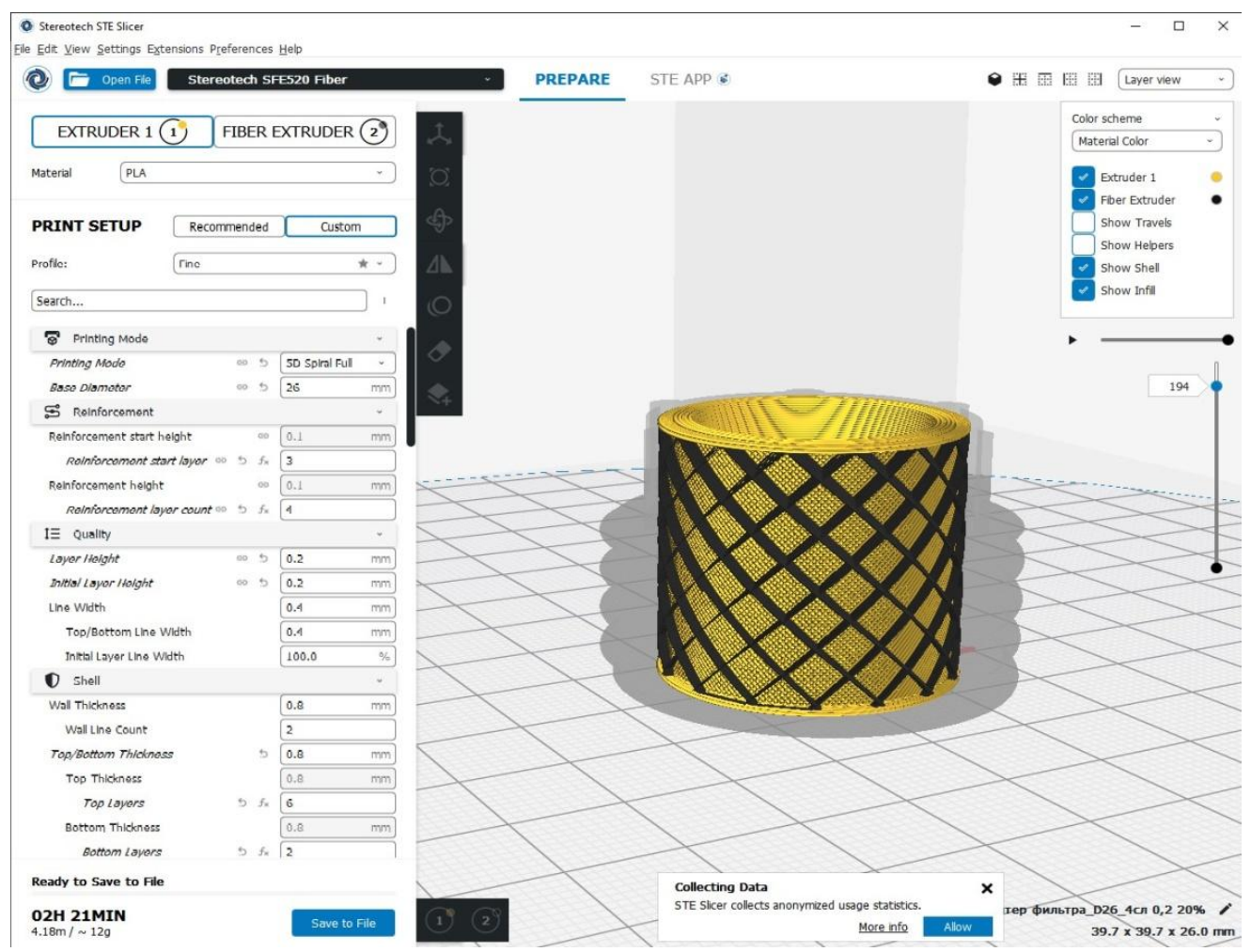

Рис. 3. Интерфейс слайсера для создания изделий по пяти координатам с армированием 

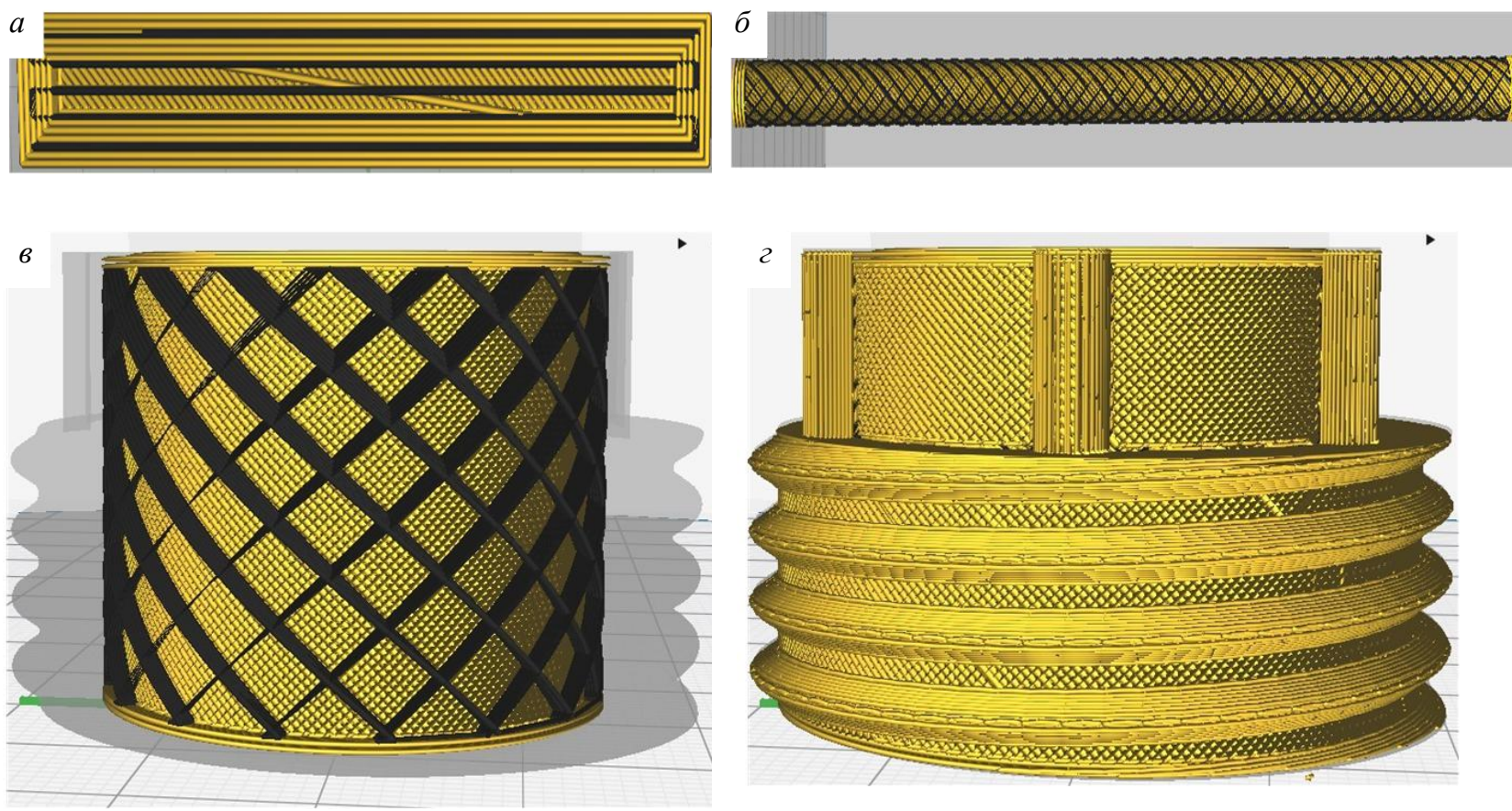

Рис. 4. Подготовка 3D моделей для печати с армированием:

$a$ - призматический брусок с плоским армированием; $\sigma$ - призматический брусок с цилиндрическим армированием; 6 - модель адаптера противовирусного фильтра с армированием (в разрезе, показаны армирующие волокна); 2 - модель адаптера противовирусного фильтра (показана оболочка из термопластика)

С помощью разработанного слайсера сгенерированы программы производства призматических брусков размером $100 \times 15 \times 8$ мм (рис. 4 , $a$ и б) с плоским и цилиндрическим армированием, а также адаптеров противовирусных фильтров (рис. 4, в и г) с цилиндрическим армированием.

Для проверки предложенных решений опытный образец принтера был оснащен экструдером для печати непрерывным волокном и

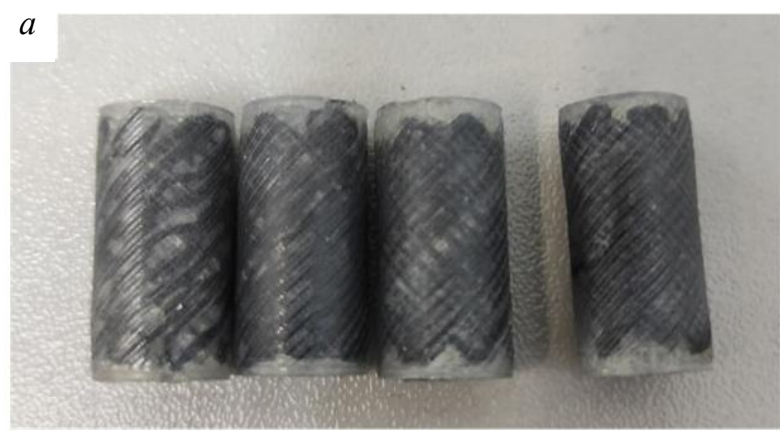

Рис. 5. Напечатанные пробные изделия с непрерывным армированием волокном: $a$-цилиндрическая деталь с плотным армированием; $\sigma$ - адаптер противовирусного фильтра с редким армированием в несколько слоев

Итак, было установлено, что по причине технических сложностей с пропиткой арми-

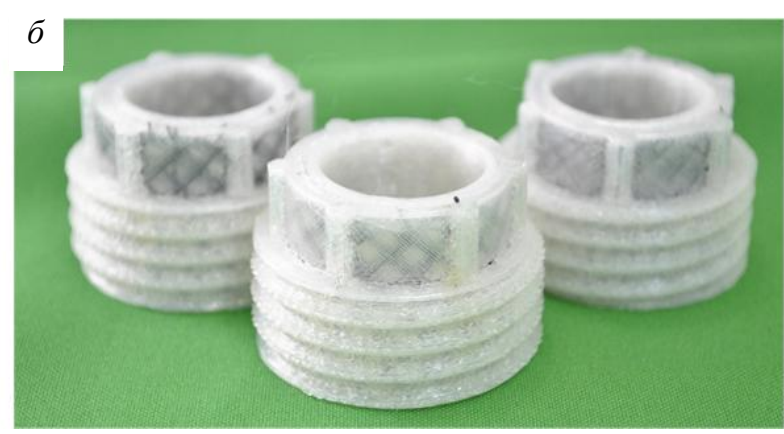

системой подачи волокна в экструдер. Для устранения проблемы неравномерной пропитки волокна использовался препрег с термопластичным связующим, разработанный компанией Markforged. Экструдер для волокна и система его подачи заменяют соответственно дополнительный экструдер для пластикового филамента и крепление дополнительной катушки материала, которые имеют место в обычном двухэкструдерном 3D принтере.

рующих волокон в процессе печати, приводящей к значительной пористости в слое армиро- 
вания, целесообразно печатать волокном, предварительно пропитанным термопластичным связующим. В рамках разработки конструкции опытного образца принтера для печати непрерывным волокном было установлено, что армирование «в плоскости» повышает прочность изделия только в одном или максимум в двух направлениях, а в направлении, перпендикулярном оси построения, прочность изделия в несколько раз меньше, чем в слое армирования. Поэтому для получения симметричного армирования нужно строить изделие не из плоских слоев, а из пространственных пересекающихся траекторий, для чего необходимо задействовать дополнительные степени свободы в системе заготовка-инструмент. Наиболее рациональным представляется использование пяти степеней свободы [10]. Для их применения разработано собственное программное обеспечение для автоматической генерации программы производства изделия по его 3D модели.

Следующий этап в разработке опытного образца принтера - отладка программного обеспечения и технологии производства армированных волокном изделий. После получения удовлетворительных результатов по печати более сложных моделей с армированием также необходимо провести прочностные испытания для оценки влияния непрерывного армирования по 5 координатам в сравнении с 3-координатной укладкой волокна.

\section{БИБЛИОГРАФИЧЕСКИЙ СПИСОК}

1. Валетов, B. А. Аддитивные технологии (состояние и перспективы) : учебное пособие / В. А. Валетов. Санкт-Петербург : Университет ИТМО, 2015. - 63 с.

2. Experimental Optimization of Fused Deposition Modelling Processing Parameters: A Design-for-Manufacturing Approach / A. Alafaghani, A. Qattawi, B. Alrawi, A. Guzman // Procedia Manufacturing. - 2017. - № 10. - C. 791-803. - URL:
https://www.sciencedirect.com/science/article/pii/S235197891 7302615 (дата обращения: 23.03.2021)

3. Hambali, R. H. Determination of the effect of part orientation to the strength value on additive manufacturing FDM for end-use parts by physical testing and validation via threedimensional finite element analysis / R. H. Hambali, P. Smith, A. Rennie. // International Journal of Materials Engineering Innovation. - 2012. - № 3 (3/4). - C. 269-281.

4. Yasa, E. Additive Manufacturing of Polymer Matrix Composites / E. Yasa, K. Ersoy. // Aircraft Technology. - 2018. № 7. - C. 147-169. - URL: https://cdn.intechopen.com/pdfs/ 60211.pdf (дата обращения: 20.03.2021).

5. Strength Increasing Additive Manufacturing Fused Filament Fabrication Technology, Based on Spiral Toolpath Material Deposition / А.Р. Авдеев, А.А. Швец, И.А. Гущин [и др.]. // Machines. - 2019. - № 7 (3). - 18 с. - URL : https://www.mdpi.com/2075-1702/7/3/57 (дата обращения: 02.04.2021).

6. Mason, H. 3D printing with continuous fiber: A landscape / H. Mason, G. Gardiner // CompositesWorld : [сайт]. 2020. - 15 окт. - URL: https://www.compositesworld.com/ articles/3d-printing-with-continuous-fiber-a-landscape (дата обращения: 02.04.2021)

7. Markforged Composites Datasheet [Электронный pecypc] // Markforged, Inc. - 2020. - URL: https://wwwobjects.markforged.com/craft/materials/composites-data-sheet.pdf (дата обращения: 31.03.2021).

8. Zhang, D. Reliable Optimized Structures with High Performance Continuous Fiber Thermoplastic Composites From Additive Manufacturing (AM) / D. Zhang, N. Rudolph, P. Woytowitz. // SAMPE 2019 Conference \& Exhibition, 2023 May 2019, Charlotte, NC, USA. - Diamond Bar, CA, United States : SAMPE Journal, 2019. - 20 c. - URL: https://www.semanticscholar.org/paper/Reliable-OptimizedStructures-with-High-Performance-Zhang-

Rudolph/6c376e30cdf8c17a91951492caaae8ba2b44fbbc (дата обращения: 02.04.2021).

9. Z-Pinning approach for 3D printing mechanically isotropic materials / C. Duty, J. Failla, S. Kim [и др.]. // Additive Manufacturing. - 2019. - № 27. - C. 175-184. - URL: https://www.sciencedirect.com/science/article/abs/pii/S221486 0418310492 (дата обращения: 06.02.2021).

10. Пушкарев, В. В. Компоновка устройств для объемной печати экструдируемым расплавом деталей сложной формы / В. В. Пушкарев, А. В. Дроботов // Известия ВолгГТУ : межвуз. сб. науч. ст. № 20 (123) / ВолгГТУ. Волгоград, 2013. - (Серия «Прогрессивные технологии в машиностроении»; вып. 1). - С. 121-123. 
УДК 629.369

DOI: $10.35211 / 1990-5297-2021-8-255-87-90$

\author{
Н. Г. Шаронов ${ }^{1,2}$, И. С. Пеньшин ${ }^{1,3}$, В. В. Гулевский ${ }^{1,3}$ \\ ЭКСПЕРИМЕНТАЛЬНАЯ УСТАНОВКА ИССЛЕДОВАНИЯ \\ ТЕХНОЛОГИИ ПОЗИЦИОНИРОВАНИЯ ЯКОРНО-ТРОСОВЫХ ДВИЖИТЕЛЕЙ* \\ ${ }^{1}$ Волгоградский государственный технический университет \\ ${ }^{2}$ Центр технологий компонентов робототехники и мехатроники \\ ${ }^{3}$ АО «ФНПЦ еТитан-баррикады"» \\ E-mail: sharonov@vstu.ru
}

Рассмотрены особенности устройства экспериментальной установки с якорно-тросовым движителем. Синтезирован алгоритм дискретного взаимодействия с грунтом. Определены особенности аппаратной реализации системы управления.

Ключевые слова: экспериментальная установка, якорно-тросовый движитель, подводный мобильный робот.

$$
\begin{array}{r}
\text { N. G. Sharonov }{ }^{1,2}, \text { I. S. Penshin }{ }^{1,3}, \text { V. V. Gulevsky } \\
\text { EXPERIMENTAL DEVICE FOR RESEARCHING THE TECHNOLOGY } \\
\text { OF ANCHOR-CABLE MOVERS POSITIONING } \\
{ }^{1} \text { Volgograd State Technical University } \\
{ }^{2} \text { Center for Technology Components of Robotics and Mechatronics } \\
{ }^{3}{ }^{\text {JSC }} \text { «FRPC } \text { «Titan - Barrikady» }
\end{array}
$$

The features of the design of the experimental device with an anchor-cable propulsion unit are considered. An algorithm for discrete interaction with soil is synthesized. Determination of the features of the hardware implementation of the control system.

Keywords: experimental device, anchor-cable mover, underwater mobile robot.

\section{Введение}

Транспортные средства, движущиеся по дну [1], по большей части являются аналогами наземных машин, модифицированных для работы под водой, что накладывает на них ряд ограничений, таких как: ограниченный радиус действия от базовой станции или берега, небольшая глубина, доступная для робота, возможность движения исключительно по подготовленному дну, высокий риск увязки гусениц, колес в илистом дне [2]. Мобильные устройства, перемещающиеся в толще воды, обладают большей мобильностью и способны работать на более широком диапазоне глубин, но в то же время у них есть ряд серьезных недостатков, препятствующих их широкому использованию в промышленных целях, а именно: ограниченная грузоподъемность, невозможность работать в местах с сильным подводным течением.

\section{Якорно-тросовый движитель}

Большинство перечисленных выше недостатков существующих мобильных подводных систем лишены мобильные платформы с якорно-канатной двигательной установкой [3]. Движение робота с якорно-тросовым движителем осуществляется за счет циклического воздействия исполнительного механизма, в данном случае маховиков с тросами, на якорь, который является органом робота для взаимодействия с поверхностью. Схема движения робота с якорно-тросовым движителем представлена на рис. 1.

Движение происходит следующим образом: якорь 1 зацепляется с землей 7 и соединяется с тяговым тросом 2 и несущим тросом 3 , которые соединены с маховиками 4. В начале движения тяговый трос 2 тянет за собой весь робот к якорю 1 , пока трос 2 не займет вертикальное положение. После этого трос 2 начинает поднимать якорь 1 и в определенный момент включается маховик с тросом 3, который переводит якорь 1 в исходное положение, описывая траекторию 6. Таким образом, циклически происходит движение якорно-канатной движителя.

(C) Шаронов Н. Г., Пеньшин И. С., Гулевский В. В., 2021.

* Работа выполнена при финансовой поддержке Российского фонда фундаментальных исследований (проекты № 20-38-90281, № 20-38-90283). 

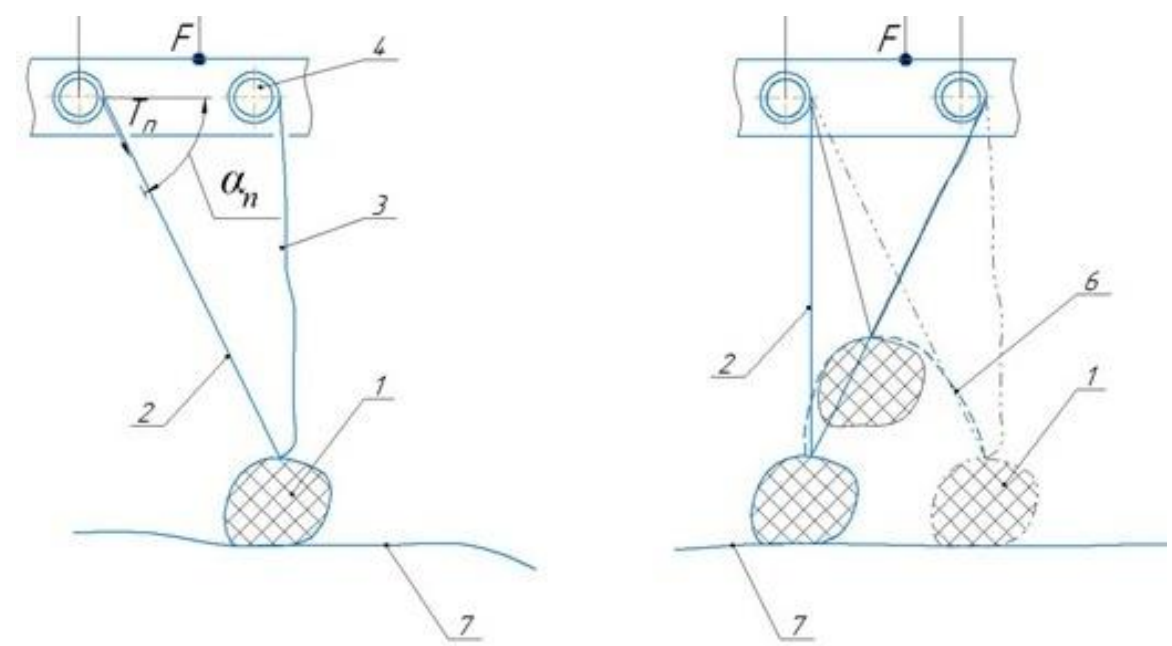

Рис. 1. Кинематическая схема и принцип работы якорно-тросового движителя подводного мобильного робота с положительной плавучестью

\section{Якорно-тросово-гусеничный движитель}

Существует также вторая принципиальная схема якорно-тросово-гусеничного движителя исключающая из схемы на рис. 1 лебедки и систему управления ими, что позволит удешевить разработку и производство подобного аппарата, но ограничит сферу его применения зонами с относительно плоским дном. Принципиальная схема подобной мобильной платформы представлена на рис. 2.

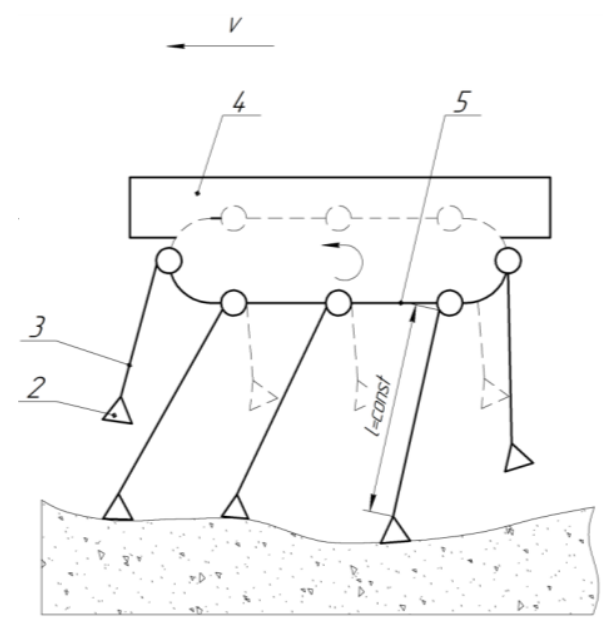

Рис. 2. Принципиальная схема мобильной платформы с гусенично-якорно-тросовым движителем

Принципиальная схема якорно-тросовогусеничного движителя представленного на рис. 2 состоит из следующих элементов: платформы 4, обладающей регулируемой переменной плавучестью; гусеницы (транспортера ) 5 вращающейся в сторону движения платформы, якорь 2 соединенный с лебедкой тросом 3 , механизм перекоса гусеницы 1 .
Отличием данный схемы якорно-тросовогусеничного движителя является отсутствие лебедок на каждый трос якоря, фиксированная длина троса якоря, а также наличие механизма перекоса гусеницы (транспортера) относительно горизонтальной плоскости платформы 4. Перемещение мобильной платформы происходит следующим образом: гусеница 5 вращается, якоря находящиеся в нижней ветви гусеницы опущены на дно, длина троса фиксирована во время перебега гусеницы. В момент подхода точки закрепления троса на гусенице к корме платформы, якорь отрывается от дна, за счет существующего перекоса гусеницы, до момента перебега этой части гусеницы к носовой части платформы.

\section{Разработка экспериментальной установки}

В создании роботов в целом и подводных роботов в частности необходимо решать задачу об оптимальном расположении движителей для наибольшей управляемости и максимального коэффициента энергосбережения.

На кафедре теоретической механики ВолгГТУ ведутся работы по разработке роботов платформ для движения и перемещения полезных масс в толще воды и на ее поверхности.

Прототип робота, имеющего якорно-тросовый движитель, представлен на рис. 3 , использует гибкие связи (тросы) совместно с грузамиякорями, адаптирующимися к различному рельефу дна. Передвижение робота, обладающего якорно-тросовым движителем, осуществляется за счет циклического воздействия исполняющим механизмом, в данном случае маховиками с тросами, на якорь, который является органом зацепления робота к поверхности. 


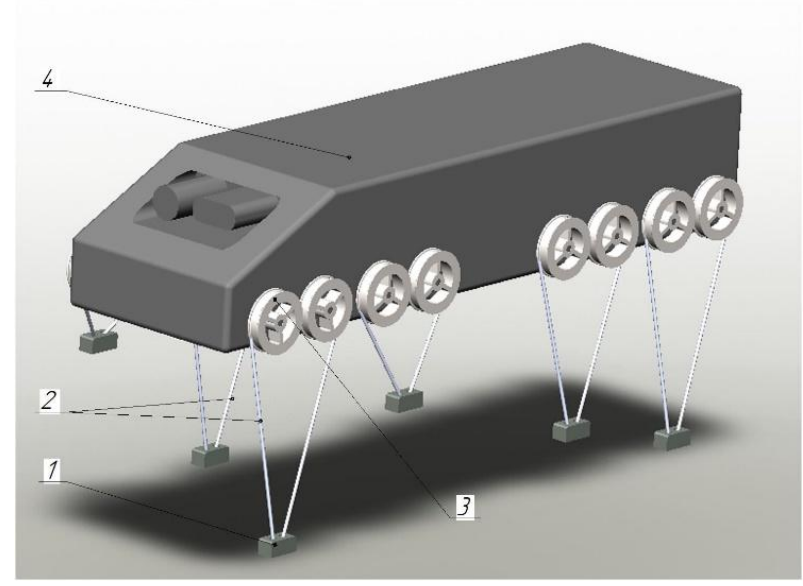

Рис. 3. Экспериментальная установка исследования технологии позиционирования якорно-тросовых движителей

При проектировании стенда были определены следующие исходные данные: габаритные размеры движителей (Д×Ш×В) не должны превышать $120 \times 100 \times 100$ мм; вес движителя не должен превышать 3 кг; скорость перемещения якорей- до $0,1 \mathrm{~m} / \mathrm{c}$; напряжение питания постоянным током - $12 \mathrm{~B}$; аппаратура должна выдерживать воздействие водяных брызг; конструкция изделия должна обеспечивать удобный доступ к основным узлам для проведения ремонта и замены вышедших из строя элементов; конструкция изделия должна быть модульной и предназначенной для конфигурирования платформы с якорно-тросовыми движителями с целью проведения научно-исследовательских работ. Реконфигурация изделия должна производиться посредством монтажа и демонтажа отдельных модулей.

Для полноты исследований и имитации полноценного робототехнического комплекса, независимо от типа движителей, должны применятся некоторые технические решения, общие для базовой конструкции платформы.

Одной из особенностей исследовательской модели является присутствие системы технического зрения. Система должна базироваться либо на цифровых камерах с разрешением съемки, достаточном для распознавания объектов, либо в системе также должны присутствовать дополнительные датчики, например, ультразвуковые для возможности сканирования пространства и создания локальной карты для прокладывания маршрута.

Особенностью разрабатываемого стенда можно считать разделение управляющей сис- темы на несколько уровней. Высший уровень это управление и коррекция управляющей программы на ЭВМ. Далее, следует уровень локального управляющего компьютера. В случае применения микропроцессорных решений типа Raspberry PI, либо NVIDIA Jetson nano, уровень с управлением и коррекцией программы и уровень с локальным управляющим компьютером, сливаются в один, в виду технических особенностей и возможности данных микрокомпьютеров выполнять функции ЭВМ в масштабах, достаточных для реализации управления и коррекции управляющей программы для исследовательского стенда реконфигурируемой платформы для тросовых типов движителей. Низшим уровнем в иерархии системы управления следует обозначить уровень, на котором происходит взаимодействие драйверов и двигателей, а также датчиков. На этом уровне происходит непосредственное выполнение управляющей программы, сбор данных для корректировки ошибок. Системой технического зрения с камеры и датчиков собираются данные, обработка всех данных происходит на высших уровнях системы управления.

Робототехнический комплекс представляет собой набор модулей с якорно-тросовыми движителями, расположенными на монтажных платформах. Каждый модуль якорно-тросового движителя включает в себя переносящий и тянущий блок. Каждый блок включает в себя шаговый электромотор с драйвером и редуктором, маховик, трос, и якорь. Таким образом стенд представляет собой полностью модульную конструкцию, которая позволяет перестраивать себя под любые нужды исследования.

Авторы выражают благодарность д.ф.н., профессору Брискину Евгению Самуиловичу за постановку задачи исследования якорно-тросового движителя.

В проведенном исследовании работа авторов распределена следующим образом:

- Н. Г. Шароновым разработано техническое задание проектирования лабораторных стендов;

- И. С. Пеньшиным разработаны методики расчета и проведено проектирование лабораторного стенда для исследования якорнотросового движителя;

- В. В. Гулевским проведено исследование конструктивных особенностей прототипа якорно-тросово-гусеничного движителя. 


\section{БИБЛИОГРАФИЧЕСКИЙ СПИСОК}

1. Чернышев, В. В. Моделирование динамики взаимодействия движителя подводного шагающего аппарата с грунтом с низкой несущей способностью / В. В. Чернышев, В. А. Шурыгин // Известия ВолгГТУ : межвуз. сб. науч. ст. № 24 (127) / ВолгГТУ. - Волгоград, 2013. - С. 82-86.

2. Основы расчета и проектирования шагающих ма- шин с цикловыми движителями : монография / Е. С. Брискин, В. В. Жога, В. В. Чернышев, А. В. Малолетов. - М. : Машиностроение, 2006. - 164 с.

3. Брискин E. C. Управление движением подводного мобильного робота с якорно-тросовыми движителями / Е. С. Брискин, Н. Г. Шаронов, В. А. Серов, И. С. Пеньшин // Робототехника и техническая кибернетика. - 2018. № 2 (19). - C. 39-45.

Свидетельство о регистрации ПИ № ФС77-61113 от 19 марта 2015 г.

Федеральной службы по надзору в сфере связи, информационных технологий и массовых коммуникаций (Роскомнадзор)

Адрес редакции и издателя: 400005, г. Волгоград, пр. В. И. Ленина, 28

Волгоградский государственный технический университет (ВолгГТУ) Телефон: гл. редактор - (8442) 24-80-00 E-mail: president@vstu.ru

Темплан 2021 г. Поз. № 3ж. Дата выхода в свет 31.08.2021 г. Формат $60 \times 84$ 1/8.

Бумага офсетная. Гарнитура Times. Печать офсетная. Усл. печ. л. 10, 70. Уч.-изд. л. 10,93. Тираж 100 экз. Свободная цена. Заказ № 458.

Оригинал-макет и электронная версия подготовлены РИО Издательства ВолгГТУ 400005, г. Волгоград, пр. В. И. Ленина, 28, корп. 7.

Отпечатано в типографии Издательства ВолгГТУ 400005, г. Волгоград, пр. В. И. Ленина, 28, корп. 7. 


\section{К СВЕДЕНИЮ \\ АВТОРОВ}

В научном журнале «Известия ВолгГТУ» серии «Прогрессивные технологии в машиностроении» публикуются статьи, которые содержат результаты теоретических и экспериментальных исследований и представляют научный и практический интерес для широкого круга специалистов в области прогрессивных технологий в машиностроении.

Вопрос об опубликовании статьи или ее отклонении решает редакционная коллегия журнала, которая утверждается ректором университета, ее решение является окончательным. Редколлегия направляет представленный для издания материал на рецензирование.

К публикации допускается не более двух статей автора в выпуске.

Рукопись должна быть набрана и сверстана в текстовом редакторе Word 2003-2010 и распечатана на лазерном принтере в режиме полной загрузки тонера. Формат бумаги A4 $(210 \times 297$ мм $)$

Для ускорения подготовки издания необходимо представлять файлы статей в электронном виде в полном соответствии с распечатанным оригиналом.

При наборе текста следует соблюдать следующие требования: поля - верхнее 2,0 см, нижнее - 3,0 cм, левое - 2,5 cм, правое - 2,5 см; шрифт Times, кегль 14, интервал полуторный.

Текст набирается с применением автоматического переноса слов, перед знаками препинания (в том числе внутри скобок) пробелы не допускаются, после них ставится один пробел. Разрядка слов не допускается, следует избегать перегрузки статей большим количеством формул, рисунков, таблиц. Для набора символов в формульном редакторе MS Equation (MS Word) использовать установки (Стиль/Размеры) только по умолчанию; рисунки должны быть выполнены в редакторах векторной графики, таких как CorelDRAW или в любом приложении к Word. Допускается сканирование рисунков в программе Microsoft Photo Editor.

Инициалы и фамилия автора (авторов) пишутся над заглавием статьи. Ниже заглавия, перед основным текстом, указывается организация или предприятие, в котором работает автор статьи, адрес электронной почты, а также аннотация и ключевые слова на русском языке. Затем на английском языке повторяются инициалы и фамилия автора (авторов), заглавие статьи, организация или предприятие, в котором работает автор статьи, аннотация и ключевые слова. В конце статьи ставится дата и подпись автора (всех авторов).

Литературные ссылки должны быть оформлены в соответствии с ГОСТ 7.1-2003 «Библиографическая запись. Библиографическое описание. Общие требования и правила составления». Библиографический список использованной литературы, составленный в порядке упоминания в тексте, дается в конце статьи; связь с основным текстом осуществляется цифровым порядковым номером в квадратных скобках в строке. Подстрочные ссылки не допускаются.

Иностранные фамилии и термины в тексте следует приводить в русском переводе В библиографическом списке фамилии авторов, полное название книг и журналов приводятся на языке оригинала.

Ссылки на неопубликованные работы не допускаются. При обозначении единиц физических величин должна применяться Международная система единиц (СИ).

Объем статьи не должен превышать семь страниц бумаги формата А4, включая таблицы и библиографический список; число рисунков - не более четырех, включая рисунки, 
помеченные буквами $a, \sigma$, и т. д. Рекомендуется включать в журнал статьи с авторским коллективом не более четырех человек с участием каждого автора в одной-двух статьях.

Статьи должны представлять сжатое четкое изложение результатов, полученных автором, без повторов приводимых данных в тексте статьи, таблицах и рисунках. К статье должны быть приложены сведения об авторах (полное имя, отчество, фамилия, ученая степень, звание, домашний адрес, номер телефона служебный, домашний, E-mail), peцензия доктора наук, компетентного в предметной области предоставляемой статьи. Для сотрудников Волгоградского государственного технического университета и подразделений также необходима документация, подтверждающая возможность открытого опубликования (экспертное заключение о возможности опубликования статьи, акт идентификации статьи). Для сторонних авторов также должно быть приложено сопроводительное письмо на имя ответственного секретаря серии с просьбой о публикации. 